
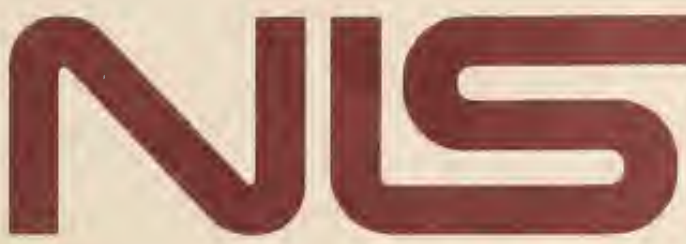

NIST

PUBLICATIONS
UNITED STATES

DEPARTMENT OF COMMERCE

TECHNOLOGY ADMINISTRATION

NATIONAL INSTITUTE OF STANDARDS AND TECHNOLOGY

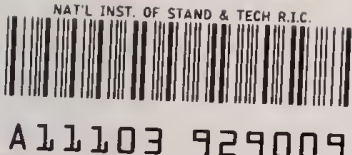

All103929009

NIST Technical Note 1356

\title{
Flow Conditioner Location Effects in Orifice Flowmeters
}

Jennifer L. Scott Charles F. Sindt Michael A. Lewis

QC

100

.05753

\#1356 



\title{
Flow Conditioner Location Effects in Orifice Flowmeters
}

\author{
Jennifer L. Scott \\ Charles F. Sindt \\ Michael A. Lewis
}

Chemical Engineering Division

Chemical Science and Technology Laboratory

National Institute of Standards and Technology

325 Broadway

Boulder, Colorado 80303-3328

January 1993

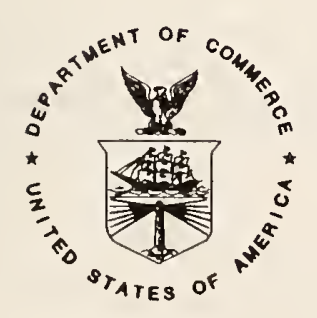

U.S. DEPARTMENT OF COMMERCE, Barbara Hackman Franklin, Secretary TECHNOLOGY ADMINISTRATION, Robert M. White, Under Secretary for Technology NATIONAL. INSTITUTE OF STANDARDS AND TECHNOLOGY, John W. Lyons, Director 
National Institute of Standards and Technology Technical Note Natl. Inst. Stand. Technol., Tech. Note 1356, 72 pages (January 1993) CODEN:NTNOEF

\section{U.S. GOVERNMENT PRINTING OFFICE \\ WASHINGTON: 1992}

For sale by the Superintendent of Documents, U.S. Government Printing Office, Washington, DC 20402-9325 


\section{CONTENT8}

Page

LIST OF FIGURES................................. iv

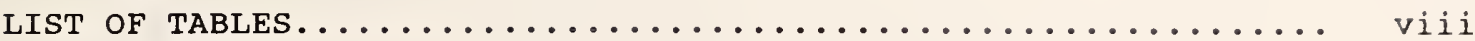

1. INTRODUCTION...................................

2. SYSTEM DESCRIPTION............................... 4

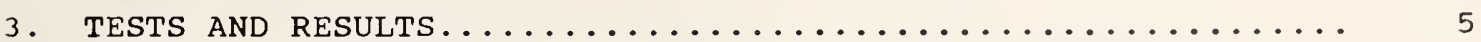

3.1 Baseline Configuration Comparison................ 5

3.2 Reducer and Elbow Disturbances.................... 6

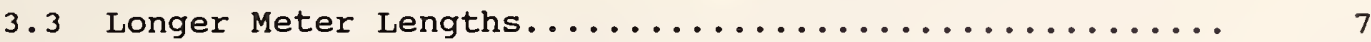

3.4 Tap Location vs. Flow Conditioner Location........... 8

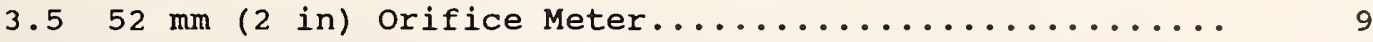

4. CONCLUSIONS AND RECOMMENDATIONS........................ 10

5. REFERENCES................................... 12

FIGURES.........................................

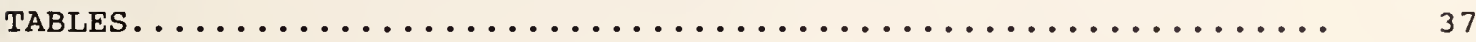


Figure 1a. In-line, 19 tube bundle flow conditioner.

Figure 1b. In-line, 7 tube bundle flow conditioner.

Figure 1c.

Zanker flow conditioner.

Figure 2 .

Flange pressure tap position code.

Figure 3 .

Baseline configuration, $104 \mathrm{~mm}$ (4 in) orifice

Figure 4 . meter.

\section{Figure 5 .}

Figure 6 .

Figure 7 .

Figure 8 .

Figure 9 .

Figure 10.

Figure 11.

Figure 12 .

Figure 13.

Figure 14.

Figure 15.

Figure 16.
Discharge coefficient vs. Reynolds number for the 0.43 beta ratio plate with an elbow and 104D straight pipe.

Discharge coefficient vs. Reynolds number for the 0.55 beta ratio plate with an elbow and 104D straight pipe.

Discharge coefficient vs. Reynolds number for the 0.67 beta ratio plate with an elbow and $104 \mathrm{D}$ straight pipe.

Discharge coefficient vs. Reynolds number for the 0.73 beta ratio plate with an elbow and $104 \mathrm{D}$ straight pipe.

Test configuration, $104 \mathrm{~mm}$ (4 in) orifice meter, reducer disturbance.

Test configuration, $104 \mathrm{~mm}$ (4 in) orifice meter, elbow disturbance.

Discharge coefficient vs. Reynolds number for the 0.55 beta ratio plate with a reducer or elbow at 21D, in-line 19 tube bundle at 19D.

Discharge coefficient vs. Reynolds number for the 0.55 beta ratio plate with a reducer or elbow at 17D, in-line 19 tube bundle at 15D.

Discharge coefficient vs. Reynolds number for the 0.55 beta ratio plate with a reducer or elbow at 13D, in-line 19 tube bundle at 11D.

Percent change in discharge coefficient vs. disturbance location for the 0.55 beta ratio plate and a reducer or elbow disturbance.

Discharge coefficient vs. Reynolds number for the 0.67 beta ratio plate with a reducer or elbow at 21D, in-line 19 tube bundle at $19 \mathrm{D}$.

Discharge coefficient vs. Reynolds number for the 20 0.67 beta ratio plate with a reducer or elbow at 17D, in-line 19 tube bundle at 15D.

Discharge coefficient vs. Reynolds number for the 0.67 beta ratio plate with a reducer or elbow at 13D, in-line 19 tube bundle at $11 \mathrm{D}$. 
Figure 17. Percent change in discharge coefficient vs.

disturbance location for the 0.67 beta ratio

plate and a reducer or elbow disturbance.

Figure 18. Test configuration, $104 \mathrm{~mm}$ (4 in) orifice meter, 22 elbow disturbance.

Figure 19. Discharge coefficient vs. Reynolds number for the

0.55 beta ratio plate with an elbow at 17D, an in-line 19 tube bundle at 15D, and 2 flange tap locations.

Figure 20. Discharge coefficient vs. Reynolds number for the 0.55 beta ratio plate with an elbow at $22 \mathrm{D}$, an in-line 19 tube bundle at 15D, and 2 flange tap locations.

Figure 21. Discharge coefficient vs. Reynolds number for the 0.55 beta ratio plate with an elbow at $34 \mathrm{D}$, an in-line 19 tube bundle at 15D, and 2 flange tap locations.

Figure 22. Percent change in discharge coefficient vs. elbow

location for the 0.55 beta ratio plate with an in-line, 19 tube bundle at 15D and 2 flange tap locations.

Figure 23. Discharge coefficient vs. Reynolds number for the 0.67 beta ratio plate with an elbow at $17 \mathrm{D}$, an in-line 19 tube bundle at 15D, and 2 flange tap locations.

Figure 24. Discharge coefficient vs. Reynolds number for the 25 0.67 beta ratio plate with an elbow at $22 \mathrm{D}$, an in-line 19 tube bundle at 15D, and 2 flange tap locations.

Figure 25. Discharge coefficient vs. Reynolds number for the 0.67 beta ratio plate with an elbow at $34 \mathrm{D}$, an in-line 19 tube bundle at 15D, and 2 flange tap locations.

Figure 26. Percent change in discharge coefficient vs. elbow location for the 0.67 beta ratio plate with an in-line, 19 tube bundle at 15D and 2 flange tap locations.

Figure 27. Test configuration, $104 \mathrm{~mm}$ (4 in) orifice meter, elbow at 17D.

Figure 28. Discharge coefficient vs. Reynolds number for the 0.55 beta ratio plate with an elbow at $17 \mathrm{D}$, an in-line, 19 tube bundle at 13D, and 2 flange tap locations.

Figure 29. Discharge coefficient vs. Reynolds number for the 27 0.55 beta ratio plate with an elbow at $17 \mathrm{D}$, an in-line, 19 tube bundle at 11D, and 2 flange tap locations. 
Figure 30. Percent change in discharge coefficient vs.

flow conditioner location for the 0.55 beta ratio plate with an elbow at 17D and 2 flange tap

locations.

Figure 31. Discharge coefficient vs. Reynolds number for the

0.67 beta ratio plate with an elbow at 17D, an in-line, 19 tube bundle at 13D, and 2 flange tap locations.

Figure 32. Discharge coefficient vs. Reynolds number for the 0.67 beta ratio plate with an elbow at $17 \mathrm{D}$, an in-line, 19 tube bundle at 11D, and 2 flange tap locations.

Figure 33

Percent change in discharge coefficient vs. flow conditioner location for the 0.67 beta ratio plate with an elbow at $17 \mathrm{D}$ and 2 flange tap locations.

Figure 34. Discharge coefficient vs. Reynolds number for the 0.73 beta ratio plate with an elbow at 17D, an in-line, 19 tube bundle at 15D, and 2 flange tap locations.

Figure 35. Discharge coefficient vs. Reynolds number for the 0.73 beta ratio plate with an elbow at 17D, an in-line, 19 tube bundle at 13D, and 2 flange tap locations.

Figure 36. Discharge coefficient vs. Reynolds number for the 0.73 beta ratio plate with an elbow at $17 \mathrm{D}$, an in-line, 19 tube bundle at 11D, and 2 flange tap locations.

Figure 37. Percent change in discharge coefficient vs. flow conditioner location for the 0.73 beta ratio plate with an elbow at $17 \mathrm{D}$ and 2 flange tap locations.

Figure 38. Discharge coefficient vs. Reynolds number for the 0.55 beta ratio plate with an elbow at $17 \mathrm{D}$, a Zanker 16D, and 2 flange tap locations.

Figure 39. Discharge coefficient vs. Reynolds number for the 0.67 beta ratio plate with an elbow at 17D, a Zanker at 16D, and 2 flange tap locations.

Figure 40. Discharge coefficient vs. Reynolds number for the 0.73 beta ratio plate with an elbow at $17 \mathrm{D}$, a Zanker at 16D, and 2 flange tap locations.

Figure 41. Baseline configuration, $52 \mathrm{~mm}$ (2 in) orifice meter, oversize Sprenkle at $44 \mathrm{D}$.

Figure 42. Discharge coefficient vs. Reynolds number for the 0.54 beta ratio plate, oversize sprenkle at $44 \mathrm{D}$, and 4 flange tap locations.

Figure 43. Discharge coefficient vs. Reynolds number for the 0.67 beta ratio plate, oversize sprenkle at 44D, and 4 flange tap locations. 


\section{LI8T OF FIGURE8}

Page

Figure 44. Test configuration, $52 \mathrm{~mm}$ ( $2 \mathrm{in}$ ) orifice meter, 35 elbow at 17D.

Figure 45. Discharge coefficient vs. Reynolds number for the 0.54 beta ratio plate, elbow at 17D, and an in-line, 7 tube bundle at $12 \mathrm{D}$.

Figure 46. Discharge coefficient vs. Reynolds number for the 0.67 beta ratio plate, elbow at 17D, and an in-line, 7 tube bundle at 12D. 
Table 1. Cross reference chart. 3

Table 2. Flow conditioner codes, descriptions, and measurements. 4

Table 3. Measured and calculated quantities for 0.43 beta ratio, 37 elbow at $104 \mathrm{D}$.

Table 4. Measured and calculated quantities for 0.55 beta ratio, 37 elbow at $104 \mathrm{D}$.

Table 5. Measured and calculated quantities for 0.67 beta ratio, elbow at $104 \mathrm{D}$.

Table 6. Measured and calculated quantities for 0.73 beta ratio, elbow at $104 \mathrm{D}$.

Table 7. Measured and calculated quantities for 0.55 beta ratio, reducer at 21D, IT1 at 19D, flange taps at position A.

Table 8. Measured and calculated quantities for 0.55 beta ratio, elbow at 21D, IT1 at 19D, flange taps at position A.

Table 9. Measured and calculated quantities for 0.55 beta ratio, reducer at $17 D$, IT1 at 15D, flange taps at position A.

Table 10. Measured and calculated quantities for 0.55 beta ratio, elbow at 17D, IT1 at 15D, flange taps at position A.

Table 11. Measured and calculated quantities for 0.55 beta ratio, reducer at 13D, IT1 at 11D, flange taps at position A.

Table 12. Measured and calculated quantities for 0.55 beta ratio, elbow at 13D, IT1 at 11D, flange taps at position $A$.

Table 13. Measured and calculated quantities for 0.67 beta ratio, reducer at 21D, IT1 at 19D, flange taps at position A.

Table 14. Measured and calculated quantities for 0.67 beta ratio, elbow at 21D, IT1 at 19D, flange taps at position A.

Table 15. Measured and calculated quantities for 0.67 beta ratio, reducer at 17D, IT1 at 15D, flange taps at position A.

Table 16. Measured and calculated quantities for 0.67 beta ratio, elbow at 17D, IT1 at 15D, flange taps at position $A$.

Table 17. Measured and calculated quantities for 0.67 beta ratio, reducer at 13D, IT1 at 11D, flange taps at position A.

Table 18. Measured and calculated quantities for 0.67 beta ratio, elbow at 13D, IT1 at 11D, flange taps at position $A$.

Table 19. Measured and calculated quantities for 0.55 beta ratio, elbow at 17D, IT1 at 15D, flange taps at position A.

Table 20. Measured and calculated quantities for 0.55 beta ratio, elbow at 17D, IT1 at 15D, flange taps at position C.

Table 21. Measured and calculated quantities for 0.55 beta ratio, elbow at 22D, IT1 at 15D, flange taps at position $A$. 
Table 22. Measured and calculated quantities for 0.55 beta ratio,

elbow at 22D, IT1 at 15D, flange taps at position $C$.

Table 23. Measured and calculated quantities for 0.55 beta ratio,

elbow at 34D, IT1 at 15D, flange taps at position $A$.

Table 24. Measured and calculated quantities for 0.55 beta ratio, elbow at 34D, IT1 at 15D, flange taps at position C.

Table 25. Measured and calculated quantities for 0.67 beta ratio, elbow at 17D, IT1 at 15D, flange taps at position A.

Table 26. Measured and calculated quantities for 0.67 beta ratio, reducer at $17 \mathrm{D}, \mathrm{IT} 1$ at $15 \mathrm{D}$, flange taps at position $\mathrm{C}$.

Table 27. Measured and calculated quantities for 0.67 beta ratio, elbow at 22D, IT1 at 15D, flange taps at position A.

Table 28. Measured and calculated quantities for 0.67 beta ratio, elbow at 22D, ITI at 15D, flange taps at position $C$.

Table 29. Measured and calculated quantities for 0.67 beta ratio, elbow at 34D, IT1 at 15D, flange taps at position A.

Table 30. Measured and calculated quantities for 0.67 beta ratio, elbow at $34 \mathrm{D}$, IT1 at 15D, flange taps at position $C$.

Table 31. Measured and calculated quantities for 0.55 beta ratio, elbow at 17D, IT1 at 13D, flange taps at position A.

Table 32. Measured and calculated quantities for 0.55 beta ratio, elbow at 17D, IT1 at 13D, flange taps at position $C$.

Table 33. Measured and calculated quantities for 0.55 beta ratio, elbow at 17D, IT1 at 11D, flange taps at position A.

Table 34. Measured and calculated quantities for 0.55 beta ratio, elbow at 17D, IT1 at 11D, flange taps at position $C$.

Table 35. Measured and calculated quantities for 0.67 beta ratio, elbow at 17D, IT1 at 13D, flange taps at position $A$.

Table 36. Measured and calculated quantities for 0.67 beta ratio, elbow at 17D, IT1 at 13D, flange taps at position $C$.

Table 37. Measured and calculated quantities for 0.67 beta ratio, elbow at 17D, IT1 at 11D, flange taps at position $A$.

Table 38. Measured and calculated quantities for 0.67 beta ratio, elbow at 17D, IT1 at 11D, flange taps at position C.

Table 39. Measured and calculated quantities for 0.73 beta ratio, elbow at 17D, IT1 at 15D, flange taps at position A.

Table 40. Measured and calculated quantities for 0.73 beta ratio, elbow at 17D, IT1 at 15D, flange taps at position C.

Table 41. Measured and calculated quantities for 0.73 beta ratio, elbow at 17D, IT1 at 13D, flange taps at position A. 
Table 42. Measured and calculated quantities for 0.73 beta ratio,

elbow at 17D, IT1 at 13D, flange taps at position C.

Table 43. Measured and calculated quantities for 0.73 beta ratio, elbow at 17D, IT1 at 11D, flange taps at position A.

Table 44. Measured and calculated quantities for 0.73 beta ratio, elbow at 17D, ITI at 11D, flange taps at position C.

Table 45. Measured and calculated quantities for 0.55 beta ratio, elbow at 17D, Zanker at 16D, flange taps at position A.

Table 46. Measured and calculated quantities for 0.55 beta ratio, elbow at 17D, zanker at 16D, flange taps at position C.

Table 47. Measured and calculated quantities for 0.67 beta ratio, elbow at $17 \mathrm{D}$, Zanker at 16D, flange taps at position A.

Table 48. Measured and calculated quantities for 0.67 beta ratio, elbow at 17D, Zanker at 16D, flange taps at position C.

Table 49. Measured and calculated quantities for 0.73 beta ratio, elbow at 17D, Zanker at 16D, flange taps at position A.

Table 50. Measured and calculated quantities for 0.73 beta ratio, elbow at 17D, Zanker at 16D, flange taps at position C.

Table 51. Measured and calculated quantities for 0.54 beta ratio, oversize Sprenkle at 44D, flange taps at position $A$.

Table 52. Measured and calculated quantities for 0.54 beta ratio, oversize Sprenkle at 44D, flange taps at position $B$.

Table 53. Measured and calculated quantities for 0.54 beta ratio, oversize Sprenkle at 44D, flange taps at position $C$.

Table 54. Measured and calculated quantities for 0.54 beta ratio, oversize Sprenkle at 44D, flange taps at position D.

Table 55. Measured and calculated quantities for 0.67 beta ratio, oversize sprenkle at 44D, flange taps at position A.

Table 56. Measured and calculated quantities for 0.67 beta ratio, oversize sprenkle at 44D, flange taps at position B.

Table 57. Measured and calculated quantities for 0.67 beta ratio, oversize Sprenkle at 44D, flange taps at position C.

Table 58. Measured and calculated quantities for 0.67 beta ratio, oversize Sprenkle at 44D, flange taps at position $D$.

Table 59. Measured and calculated quantities for 0.54 beta ratio plate, elbow at 17D, IT3 at 12D, flange taps at position A.

Table 60. Measured and calculated quantities for 0.54 beta ratio plate, elbow at 17D, IT3 at 12D, flange taps at position B.

Table 61. Measured and calculated quantities for 0.54 beta ratio plate, elbow at 17D, IT3 at 12D, flange taps at position c. 
Table 62. Measured and calculated quantities for 0.54 beta ratio plate, elbow at 17D, IT3 at 12D, flange taps at position D.

Table 63. Measured and calculated quantities for 0.67 beta ratio 56 plate, elbow at 17D, IT3 at 12D, flange taps at position A.

Table 64. Measured and calculated quantities for 0.67 beta ratio plate, elbow at 17D, IT3 at 12D, flange taps at position $B$.

Table 65. Measured and calculated quantities for 0.67 beta ratio plate, elbow at 17D, IT3 at 12D, flange taps at position c.

Table 66. Measured and calculated quantities for 0.67 beta ratio plate, elbow at 17D, IT3 at 12D, flange taps at position D. 



\title{
FLOW CONDITIONER LOCATION EFFECTB IN ORIFICE FLOWMETERS
}

\author{
Jennifer L. Scott, Charles F. Sindt \\ Michael A. Lewis \\ Chemical Engineering Division \\ Chemical Science and Technology Laboratory \\ National Institute of Standards and Technology \\ 325 Broadway \\ Boulder, Colorado 80303-3228
}

\begin{abstract}
Tests sponsored by Gas Research Institute were conducted with orifice flowmeters of two nominal sizes: $104 \mathrm{~mm}$ (4 in) and $52 \mathrm{~mm}$ (2 in). For the $104 \mathrm{~mm}$ orifice meter we compared discharge coefficients measured in two common piping configurations used by laboratories to establish baseline flow conditions. The discharge coefficients are similar for beta ratios of $0.43,0.55$, and 0.67 , but not for the 0.73 beta ratio plate. For other tests with this orifice meter, a $90^{\circ}$ elbow or a reducer was located upstream of the orifice plate and flow conditioner. Two beta ratios $(0.54,0.67)$ were tested in the $52 \mathrm{~mm}$ orifice meter in baseline configuration and with an elbow at 17D and a flow conditioner at 12D. For many of the tests, differential pressures were measured at more than one flange tap location. Placing the flow conditioner too close to the orifice plate in either meter yields discharge coefficients below baseline values. The location of the flow conditioner with respect to the orifice plate appears to influence meter performance more significantly than the type or location of flow disturbance upstream of it. With larger beta ratio plates, the flange tap location affected the value of the discharge coefficients.
\end{abstract}

Key words: baseline; beta ratio; discharge coefficient; flange tap position; flow conditioner; flow disturbance; flow measurement; gas; orifice flowmeter; tube bundle

\section{INTRODUCTION}

A continuing research project at this laboratory is the measurement of the effect of upstream conditions on orifice flowmeter performance. The ultimate purpose of the work is to provide information that will lead to improved standards for orifice meter installations as specified in American Petroleum Institute (API) 14.3-American Gas Association (A.G.A.) Report No. 3, Part 2 [1] and International Organization for Standardization (ISO) 5167 [2]. Creating general installation standards is difficult due to the large variety of installation configurations used in the field.

The equation found in API 14.3-A.G.A. 3, Part 1 [3] for determining discharge coefficients in orifice flow measurement was derived from data produced in flow that was considered fully developed or 'ideal.' A coordinated program between this laboratory and others, sponsored by the Gas Research Institute, has been designed to test certain piping configurations, beta ratios (the ratio of the diameter of the hole in the orifice plate to the inner diameter of the meter tube), flow conditioners, and pressure tap locations to help answer the question: How can 'non-ideal' flow be conditioned to achieve accurate measurement? A goal of our research is to 
characterize flow measurement in orifice meters for numerous installation configurations while keeping tests to a minimum.

Research was conducted with orifice meters of two nominal sizes of $104 \mathrm{~mm}$ (4 in) and $52 \mathrm{~mm}$ (2 in). The first phase of the $104 \mathrm{~mm}$ orifice meter work was to compare the discharge coefficients measured in two common baseline configurations: (1) 46 pipe diameters (D) of straight pipe preceded by a sprenkle flow conditioner, or (2) 104D of straight pipe. Further tests with the $104 \mathrm{~mm}$ orifice meter included placing an in-line, 19 tube flow conditioner (IT1) directly downstream of a long-radius elbow or a $154 \mathrm{~mm}$ $\mathrm{x} 104 \mathrm{~mm}$ ( 6 in $\mathrm{x} 4 \mathrm{in}$ ) reducer, with the elbow or reducer located varying distances from the orifice plate.

Tests were also conducted with the $104 \mathrm{~mm}$ (4 in) orifice meter in which the distance between the long-radius elbow and orifice plate was varied while the flow conditioner remained fixed at a location 15D from the plate. Then the $104 \mathrm{~mm}$ orifice meter was tested with the flow conditioner at various locations with the elbow fixed 17D upstream of the plate. In these last two tests, measurements were made at more than one flange tap position. Flange taps were used in all measurements.

Testing with the $52 \mathrm{~mm}$ ( 2 in) orifice meter was begun by gathering baseline data for two beta ratio plates $(0.54,0.67)$. The piping configuration consisted of an oversize sprenkle flow conditioner and 44D of straight pipe upstream of the orifice plate. We also measured discharge coefficients using the same two orifice plates with an elbow 17D from the orifice plate and an in-line, 7-tube bundle flow conditioner (IT3) located 12D from the plate.

Table 1 shows the various piping configurations, orifice plates, and flange tap locations tested, and identifies the appropriate tables and figures where results for each configuration are summarized. 
Table 1. Cross reference chart.

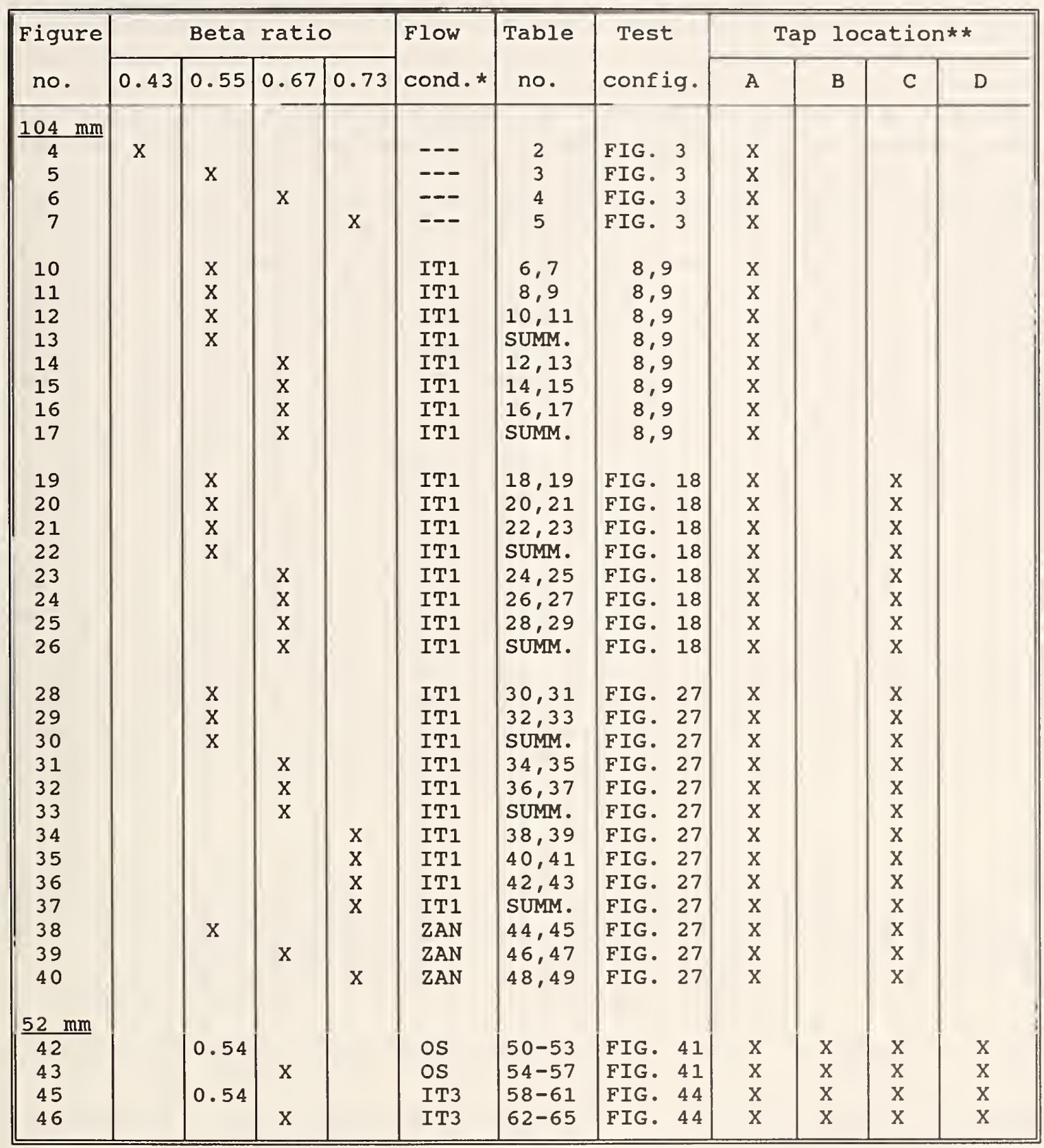

* See table 2 for details.

** See figure 2 . 


\section{SYSTEM DESCRIPTION}

The gas research facility at the National Institute of Standards and Technology in Boulder, Colorado (NIST-B), is a closed loop thermodynamic cycle in which the process fluid, nitrogen, is circulated between temperature limits of $85 \mathrm{~K}$ and $290 \mathrm{~K}$ at pressures of $0.5 \mathrm{MPa}$ to $4.1 \mathrm{MPa}$. The portion of the loop in which the orifice meter is located operates near the upper ends of the pressure and temperature ranges, $4 \mathrm{MPa}$ and $289 \mathrm{~K}\left(580 \mathrm{psia}, 60{ }^{\circ} \mathrm{F}\right)$. After the nitrogen gas is passed through the orifice meter test section it is expanded and cooled to liquid phase and weighed to determine mass flow rate.

The nominal $104 \mathrm{~mm}$ ( $4 \mathrm{in}$ ) orifice meter is made from schedule 40 stainless steel that has been bored to an internal diameter of $103.657 \mathrm{~mm}$ $(4.081 \mathrm{in})$. The orifice meters consist of three sections: approach, upstream, and downstream. Meter tube sections are pinned to ensure alignment. One of two approach sections was used in the research conducted with this orifice meter, depending upon the piping configuration. One approach section is $8 \mathrm{D}$ in length with an $\mathrm{Ra}$ of $0.76 \mu \mathrm{m}$ (30 $\mu \mathrm{in})$; the other is 6D with an Ra of $2.5 \mu \mathrm{m}(100 \mu \mathrm{in})$. Ra is the mean absolute deviation value of the surface finish measurement. The upstream section is 11D with an internal roughness of $3.8 \mu \mathrm{m}(150 \mu \mathrm{in}) \mathrm{Ra}$ and the downstream section is 16D.

The nominal $52 \mathrm{~mm}$ ( $2 \mathrm{in}$ ) orifice meter is a commercially available stainless steel flowmeter with an actual internal diameter of $52.502 \mathrm{~mm}$ $(2.067 \mathrm{in})$. We also used two approach sections with this meter. One of the sections is $34 \mathrm{D}$ in length with an internal surface roughness of $4.3 \mu \mathrm{m}$ ( 170 $\mu \mathrm{in)} \mathrm{Ra}$ and was used for baseline work. The other approach section is $8 \mathrm{D}$ and is constructed of standard schedule 40 carbon steel pipe and weld-neck flanges. The upstream section is $9 \mathrm{D}$ with a roughness of $4.1 \mu \mathrm{m}$ (160 $\mu \mathrm{in})$, and the downstream section is $20 \mathrm{D}$ with a roughness of $4.4 \mu \mathrm{m}$ (175 $\mu \mathrm{in}$ ) $\mathrm{Ra}$.

Figures $1 \mathrm{a}, 1 \mathrm{~b}$, and $1 \mathrm{c}$ show the flow conditioners used during the course of our research. The dimensions and salient features are described in table 2 .

Table 2. Flow conditioner codes, descriptions, and measurements.

\begin{tabular}{|c|c|c|c|c|c|c|}
\hline $\begin{array}{l}\text { Identi- } \\
\text { fication }\end{array}$ & Name & $\begin{array}{l}\text { Number } \\
\text { tubes / } \\
\text { blades }\end{array}$ & $\begin{array}{l}\text { Pattern/ } \\
\text { In-line (I) } \\
\text { Flanged (F) }\end{array}$ & $\begin{array}{l}\text { Dimen } \\
\text { Length }\end{array}$ & $\begin{array}{l}\text { nsion } \\
\text { OD }\end{array}$ & $\begin{array}{l}\text { mm (in) } \\
\text { Tube ID }\end{array}$ \\
\hline IT 1 & $\begin{array}{l}\text { tube } \\
\text { bundle }\end{array}$ & 19 & round-I & $\begin{array}{l}254 \\
(10)\end{array}$ & $\begin{array}{l}97 \\
(3.8)\end{array}$ & $\begin{array}{l}15 \\
(0.6)\end{array}$ \\
\hline IT3 & $\begin{array}{l}\text { tube } \\
\text { bundle }\end{array}$ & 7 & round-I & $\begin{array}{l}152 \\
(6)\end{array}$ & $\begin{array}{l}48 \\
(1.9)\end{array}$ & $\begin{array}{l}13 \\
(0.5)\end{array}$ \\
\hline $\mathrm{ZAN}$ & Zanker & $\begin{array}{c}32 \\
\text { holes }\end{array}$ & $\begin{array}{l}\text { perf. plate } \\
\text { with } \\
\text { honeycomb-F }\end{array}$ & $\begin{array}{l}108 \\
(4.3)\end{array}$ & $\begin{array}{l}102 \\
(4)\end{array}$ & --- \\
\hline os & Sprenkle & & $\begin{array}{l}\text { three perf. } \\
\text { plates (I) }\end{array}$ & $\begin{array}{r}20.3 \\
(8)\end{array}$ & $\begin{array}{l}102 \\
(4)\end{array}$ & --- \\
\hline
\end{tabular}

During some of the tests, we measured differential pressures at more than one flange tap position. Figure 2 illustrates how each tap position is referenced in this report. Location $A$ is in the plane of the nearest upstream 
elbow, along the inside of the bend. Location $\mathrm{C}$ is in the same plane but along the outside of the bend. Location B is in a plane perpendicular to the elbow and on top of the pipe, and location D is opposite of $B$.

For each beta ratio tested, we calculated discharge coefficients at four flow rates. A complete data set included at least four measurements at each flow rate taken over two days to include any effects of daily variability. For some tests we limited the number of orifice plates tested to those that would best characterize the effects of the configuration of interest.

For every configuration and/or flow conditioner we tested, a comparative method was used to evaluate the performance of the orifice meter. The discharge coefficient is compared to a 'baseline' discharge coefficient at the same pipe Reynolds number. The baseline values for the $104 \mathrm{~mm}$ (4 in) meter were determined by testing each orifice plate in a specific piping configuration consisting of an oversize Sprenkle flow conditioner and 46D of straight pipe upstream of the orifice plate. The baseline data used in this report also include discharge coefficients calculated using two other upstream configurations: 56D of straight pipe and $46 \mathrm{D}$ of straight pipe with no sprenkle flow conditioner. The results were similar for these three configurations; therefore, data from all configurations were combined [4]. These data sets were fitted to a linear curve for each beta ratio, and these curves are indicated on all figures.

Baseline data for the $52 \mathrm{~mm}$ ( 2 in) meter at selected beta ratios are included in this report. The curves representing these data are shown on the figures as will the Reader-Harris/Gallagher (RG) equation for determination of discharge coefficient found in API 14.3-A.G.A. 3, Part 1 [3].

The percent shift in orifice meter discharge coefficients resulting from specific upstream piping configurations and flow conditioner locations at selected Reynolds numbers was computed as follows:

$$
\Delta C\left(\frac{q}{b}\right)=\frac{\left(C_{\mathrm{t}}-C_{\mathrm{b}}\right) \times 100}{C_{\mathrm{b}}},
$$

where $C_{b}$ is the discharge coefficient that was experimentally determined with the baseline configurations and $c_{t}$ is the discharge coefficient calculated for the various test configurations.

\section{TESTS AND REBULTB}

\subsection{Baseline Configuration Comparison}

Baseline data from U.S. and European facilities were used to derive the recent equation revision in API 14.3-A.G.A. 3, Part 1 [3]. U.S. data were taken with a defined piping configuration of a sprenkle flow conditioner followed by $46 \mathrm{D}$ of straight pipe upstream of the orifice plate. In many cases, the Sprenkle flow conditioner was larger that the meter size. No European baseline data were collected with a sprenkle flow conditioner; however, the facilities had much longer metering runs than those used in the United States [5].

We installed $104 \mathrm{D}$ of straight pipe upstream of the orifice plate of the $104 \mathrm{~mm}$ (4 in) orifice meter and measured differential pressures for beta ratios of $0.43,0.55,0.67$, and 0.73 . The goal of this task was to compare these data with those used for our baseline [4]. Figure 3 illustrates the 
piping configuration. The flange pressure tap was located in the plane of the elbow along the inside of the bend, location A. Figures 4 through 7 display the data for each beta ratio. Also shown in each figure is the previously determined baseline for each beta ratio [4]. The data are listed in tables 3 through 6 .

Figures 4,5 , and 6 indicate that for beta ratios of $0.43,0.55$, and 0.67 , there was little difference between the discharge coefficients and the baseline curves. The differences that can be seen for these beta ratios are within the reproducibility of our gas flow system. We tested the impact that these data would have on the baseline curve by combining them with previous baseline data and creating new baseline curves. When the curves from the combined data sets were compared to the original baseline curves, the difference between the curves was less than 0.1 percent over the entire Reynolds number range for these three beta ratios.

Figure 7 shows an obvious bias in discharge coefficient between these data and the baseline for the 0.73 beta ratio plate. The discharge coefficients were higher than baseline values over the Reynolds number range. When these data were added to those making up the baseline, the new curve was from 0.15 percent to 0.2 percent higher than the baseline curve. We think that this bias warrants further investigation.

\subsection{Reducer and Elbow Disturbances}

Previous work with the $104 \mathrm{~mm}$ (4 in) orifice meter at this laboratory indicated that with a flow conditioner placed at the outlet of a tee disturbance, the discharge coefficients would be near baseline values [7]. For that work the flange taps were located in the plane of the tee and along the inside of the bend. The purpose of this test phase was to determine whether this was a good flow conditioner location for other type of disturbances that are referred to in the standard [1].

We ran tests with a single, long-radius elbow or a $154 \mathrm{~mm}$ x $105 \mathrm{~mm}$ (6 in $\mathrm{x} 4$ in) reducer as the upstream disturbance (fig. 8,9 ). The disturbance was 21,17 , or 13 pipe diameters upstream of the orifice plate as indicated by the ' $z$ ' dimension in the figures, and an in-line, 19 tube bundle flow conditioner (IT1) was placed directly downstream of the disturbance. The flange taps were located in the plane and along the inside of the last bend, location A (fig. 2). Orifice plates with beta ratios of 0.55 and 0.67 were tested in these configurations.

Figures 10 through 12 reflect the discharge coefficients when the 0.55 beta ratio plate was used. Each figure displays data from both the reducer and the elbow disturbance. These data are found in tables 7 through 12 . Figure 13 shows the relationship between experimental discharge coefficients and baseline values for both disturbances.

The results for the elbow disturbance are very similar to those reported in NIST Technical Note 1330 [6] which described the effects of flow conditioner location in undisturbed flow conditions. This work showed that, for our test facility, placing the flow conditioner more than 17D from the orifice plate increased the discharge coefficients above baseline values. Results presented here indicate that the discharge coefficients are affected more by flow conditioner location than the type and location of the disturbance upstream of it. The range of tube bundle locations for which the discharge coefficients are near baseline values is between 15D and 19D 
upstream of the orifice plate for the 0.55 beta ratio plate.

With the reducer disturbance and the 0.55 beta ratio plate the discharge coefficients approached baseline values as the flow conditioner was moved away from the orifice plate; however, the discharge coefficients were always below baseline values. When the tube bundle was 15D upstream of the orifice plate, the shift in the discharge coefficient was -0.25 percent from baseline values. At 19 diameters, the shift from baseline values was -0.15 percent.

Results were similar with the 0.67 beta ratio plate. These data are shown in figures 14,15 , and 16 and are listed in tables 13 through 18 . Once again we have plotted the results from both disturbances on each graph. The differences between experimental and baseline discharge coefficients are shown in figure 17 .

Figure 17 indicates that, with either of these disturbances, placing the flow conditioner around 15D upstream of the orifice plate will result in discharge coefficients near baseline values. The differences between experimental data and baseline values are within \pm 0.1 percent at this location. As previously reported, placing the flow conditioner too close to the orifice plate causes a negative shift in discharge coefficient. If it is too far from the plate, a positive shift occurs, unless it can be moved so far that the piping approaches baseline configuration.

If the disturbance is an elbow, a good location for the flow conditioner with the 0.55 and 0.67 beta ratio plates is apparently around 15D upstream of the orifice plate. This is consistent with previous results with a tee as a disturbance [7]. However, work at this laboratory and others has shown that the position of the flange pressure taps with respect to the elbow is important when larger beta ratio plates are used [7-10].

\subsection{Longer Meter Lengths}

Much of the recent work at this facility has been directed toward finding a good location for a flow conditioner in short metering stations $[4,7]$. We have considered configurations with 17 to 19 pipe diameters between the last disturbance and the orifice plate to simulate required piping distances specified in API 14.3-A.G.A. 3, Part 2 [1]. The standard requires a minimum distance between a partially closed valve and the 0.75 beta ratio orifice plate of $17 \mathrm{D}$ when a flow conditioner is used. There are metering stations that have more than the minimum distance between the disturbance and the plate. We examined this point by testing a tube bundle flow conditioner located 15D upstream of the orifice plate while we altered the overall meter length. The test plan was expanded to include simultaneous measurements at two flange tap locations: position $A$, inside the bend of the elbow, and position $C$, outside the bend of the elbow. The configurations tested are illustrated in figure 18.

The test with the elbow at 17D and the tube bundle directly downstream was repeated, but measurements were taken at two tap locations. The results with the 0.55 beta ratio plate are shown in figure 19. These data can be found in tables 19 and 20. At a pipe Reynolds number of $1.25 \times 10^{6}$ the difference between the discharge coefficients at the two tap locations was less than 0.1 percent (the repeatability of our transducers), and the values at each tap location were below baseline values as shown in figure 22.

Figures 20 and 21 display the discharge coefficient data for the 0.55 beta ratio plate with the elbow at distances of $22 \mathrm{D}$ and $34 \mathrm{D}$. These data can 
be found in tables 21 through 24. There is no effect of tap location, but as the elbow was moved farther from the orifice plate, the values of the discharge coefficients moved away from baseline values (figure 22).

The results for these configurations and the 0.67 beta ratio plate are shown in figures 23, 24, and 25 and are listed in tables 25 through 30 . The difference in discharge coefficient resulting from tap location was about 0.1 percent when the elbow was 17 or 22 diameters upstream of the orifice plate, but there was no difference in the data at the two tap locations when the elbow was at 34D. In addition, figure 26 shows that all discharge coefficients were near baseline values regardless of the piping configuration.

\subsection{Tap Location vs. Flow Conditioner Location}

The magnitude of the effect of tap location increases with beta ratio. Research completed at this facility with a tee disturbance indicated that as much as a 0.5 percent difference in measurement can occur between tap locations when the 0.73 beta ratio plate is used [7]. For these tests the in-line tube bundle flow conditioner was directly downstream of the tee. Researchers at another laboratory found similar results [8]. They tested the 0.75 beta ratio plate with an elbow disturbance 17D upstream of the orifice plate and a sliding, 19 tube bundle flow conditioner, which could be placed anywhere between the plate and the disturbance. Their results indicate that if the flow conditioner is moved away from the elbow, the tap location effect diminishes. However, as the flow conditioner approaches the orifice plate, the discharge coefficients move away from baseline values. We attempted to duplicate these results in our laboratory. In our tests we placed the flow conditioner at two locations between the elbow and orifice plate and included three beta ratios in the test plan.

With an elbow 17D from the orifice plate, we tested the in-line tube bundle flow conditioner at two locations: 11D and 13D upstream of the orifice plate. We tested the $0.55,0.67$, and 0.73 beta ratio plates in the configuration shown in figure 27. Tests results for beta ratios of 0.55 and 0.67 with the flow conditioner at the elbow outlet are described above. The 0.73 beta ratio measurements are included here.

Discharge coefficients for the 0.55 beta ratio plate are shown in figures 28 and 29, and are listed in tables 31 through 34 . There is no tap location effect with this beta ratio. The summary plot shown in figure 30 indicates that for this beta ratio, the best location for the flow conditioner in this piping configuration is at the outlet of the elbow.

For the 0.67 beta ratio plate, the same conclusions can be drawn. Figures 31 and 32 show a small tap location effect when the flow conditioner was at both the 11D and 13D positions. These data are listed in tables 35 through 38. This effect was as large as the effect seen when the flow conditioner was at the elbow outlet. Figure 33 shows that the discharge coefficients were nearest baseline values when the flow conditioner was at the elbow outlet.

The results for the 0.73 beta ratio plate are inconclusive because of the measurable tap location effect in all configurations. Figures 34 through 36 show the discharge coefficients at two tap locations with the flow conditioner in three positions downstream of the elbow. The data can be found in tables 39 through 44 . 
The difference in discharge coefficients between the two tap locations did not diminish as the flow conditioner was moved away from the elbow. At a pipe Reynolds number of $1.25 \times 10^{6}$ the difference in discharge coefficients between tap locations was 0.18 percent when the flow conditioner was located at the outlet flange of the elbow, and the difference was 0.3 percent when the flow conditioner was 13D upstream of the orifice plate. Figure 37 indicates that the flow conditioner could be placed between 13D and 15D upstream of the orifice plate, but depending upon the location of the pressure tap, a possible error of 0.3 percent could result.

We also conducted tests with the Zanker flow conditioner located at the elbow outlet for beta ratios of $0.55,0.67$, and 0.73 . Previous tests have shown that placing this flow conditioner at 10D with a tee located at 19D resulted in discharge coefficients within 0.15 percent of baseline values for each orifice plate used [7]. However, those tests included only one tap location: position A. Figures 38,39 , and 40 show the data with the Zanker conditioner at 16D. The figures 30,33 , and 37 compare the performance of the zanker conditioner to the tube bundle flow conditioner. The Zanker conditioner did not perform as well as the tube bundle in this location, and a pressure tap location effect was evident. These data can be found in tables 45 through 50. After analyzing one data set taken with the zanker flow conditioner, we found that this flow conditioner did not perform as well as the tube bundle at this location, and we discontinued testing with it.

\section{$3.552 \mathrm{~mm}$ (2 in) Orifice Meter}

Many gas metering stations are equipped with $52 \mathrm{~mm}(2 \mathrm{in})$ orifice meters, but there is little available gas research data in this meter size. Extensive research with water in $52 \mathrm{~mm}$ ( 2 in) orifice meters has been conducted at the National Institute of standards and Technology in Gaithersburg $[11,12]$. A recent modification to our laboratory to conduct gas research in this meter size will complement the NIST-Gaithersburg work.

The lower flow rate limits for our mass-based weighing system is 0.5 $\mathrm{kg} / \mathrm{s}(1.1 \mathrm{lb} / \mathrm{s})$. In order to test the $52 \mathrm{~mm}$ (2 in) orifice meter at low flow rates, we installed two turbine meters, in series, upstream of the orifice meter. Using a system of control valves, we bypassed part of the gas through the turbine-orifice meter arrangement while maintaining the overall flow above $0.5 \mathrm{~kg} / \mathrm{s}$. One of the turbine meters was used as the primary measurement device. We used the other turbine meter as a constant reference to the primary turbine meter by monitoring the output ratio between the two meters.

The turbine meters were calibrated over the range of our mass system. The turbine meters and associated piping were then sent to the colorado Engineering Experimental Station Incorporated (CEESI) in Nunn, colorado, to be calibrated at lower flow rates. This calibration was done using air at pressures and temperatures similar to those at which our facility operates $(3.83 \mathrm{MPa}, 290 \mathrm{~K})$. These calibration data were combined to arrive at a calibration curve for the turbine meters which covers the entire flow range.

Testing began with two beta ratios: 0.54 and 0.67 . The piping configuration used for baseline measurements is shown in figure 41 . It consisted of a $104 \mathrm{~mm}$ (4 in) sprenkle flow conditioner and 44D of straight pipe upstream of the orifice meter. We measured differential pressure at four flange tap locations, simultaneously. For each beta ratio tested, 
approximately half of the data used the mass system and the other half used the turbines to calculate discharge coefficients. Baseline data, as well as the API 14.3-A.G.A. 3 (RG) [3] equation curve are shown in figures 42 and 43 . The data are listed in tables 51 through 58.

Figure 42 indicates that for the 0.54 beta ratio plate, the discharge coefficients at all tap locations were near the values predicted by the API 14.3-A.G.A. 3 equation [3]. Baseline data for the 0.67 beta ratio plate shown in figure 43 indicate good agreement between the data and the equation at Reynolds numbers below $1.4 \times 10^{6}$. Work to investigate the shift in discharge coefficients above RG equation values at higher Reynolds numbers is scheduled. Future work will also cover a wider range of Reynolds numbers.

The approach section was replaced to create a configuration with 17D between the last elbow and the orifice plate, as shown in figure 44. An inline, 7 tube bundle flow conditioner was placed at $12 \mathrm{D}$ and the 0.54 and 0.67 orifice plates were tested.

The data for the 0.54 beta ratio plate are shown in figure 45 and are listed in tables 59 through 62. Data are about 0.2 percent lower than the values measured in the baseline configuration. There is no difference between values at the various tap locations.

The results for the 0.67 beta ratio plate are similar but exhibit a slight tap location effect. These results are shown in figure 46 , and the data are in tables 63 through 66. The largest difference in discharge coefficients occurs between the $B$ and $D$ tap locations but is less than 0.2 percent at all Reynolds numbers. The values for the $A$ and $C$ location fall between these values. In general, the discharge coefficients are about 0.2 percent below values measured in the baseline configuration but are close to equation values over the flow range.

\section{CONCLUSIONS AND RECOMENDATIONS}

Flow measurement laboratories throughout the world use various piping configurations to establish fully developed turbulent flow. Discharge coefficient data measured in these configurations were compiled and used to establish the Reader-Harris/Gallagher equation for calculation of discharge coefficients. In our system, we found no difference between discharge coefficients measured with an oversize Sprenkle flow conditioner and 46D of straight pipe or 104D of straight pipe upstream of the orifice plate for lower beta ratio values. The 0.73 beta ratio plate was consistently the most sensitive to any changes in upstream conditions in our system.

Results of the tests with the elbow and the reducer disturbances show that the flow conditioner location has a greater impact on the discharge coefficients than the location of the upstream disturbance. For beta ratios of 0.55 and 0.67 , a good location for the flow conditioner is around 15D from the orifice plate when the disturbance is located directly upstream of the flow conditioner; however, the effect of the flange tap location was not measured. Tests with the flow conditioner at 15D and the elbow at 17D, 22D, or $34 \mathrm{D}$ also indicate that $15 \mathrm{D}$ is a good location. There was a small tap location effect with the 0.67 beta ratio plate, only.

With an elbow at 17D, moving the flow conditioner closer to the orifice plate caused a negative shift in discharge coefficient which was more significant than any change in effect of the flange tap location. 
API 14.3-A.G.A. Report No. 3 [3] states that measurement uncertainties can increase with beta ratios larger than 0.6 . In our system, discharge coefficients with the flow conditioner at 15D and the 0.67 beta ratio plate were within 0.15 percent of baseline values for each of the tap location and piping configuration tested. Although work with the 0.73 beta ratio plate was limited, current and previous results show tap location effects and other inconsistencies for this beta ratio.

More work is needed with an elbow or reducer at 17D. Tests will include an examination of the effect of using no flow conditioner or using a 7 tube bundle flow conditioner. These tests should include differential pressure measurements at more than one flange tap location. Other disturbances such as a header should be tested to see if results are similar to those using an elbow disturbance.

The limited work with the $52 \mathrm{~mm}$ ( 2 in) orifice meter indicates that for the 0.54 beta ratio plate, values measured in the baseline configuration are near RG equation values. For the 0.67 beta ratio, there is a shift in discharge coefficient at a Reynolds number of about $1.4 \times 10^{6}$ which warrants further investigation.

With the flow conditioner located 12D upstream of the orifice plate and an elbow at 17D, the discharge coefficients at a Reynolds number of $1.25 \times 10^{6}$ for the 0.54 and 0.67 beta ratios were from 0.2 to 0.25 percent below baseline values, an indication that the flow conditioner is too close to the orifice plate.

Additional research is needed with the $52 \mathrm{~mm}$ (2 in) orifice meter. Work with an expanded range of beta ratios and a 19 tube bundle flow conditioner would help determine whether results with the $104 \mathrm{~mm}$ (4 in) orifice meter can be translated to other sizes. Research with high pressure gas is needed.to complement the work completed with water and oil in this orifice meter size.

\section{ACKNOWLEDGEMENTB}

The work described in this report was funded by the Gas Research Institute, Chicago, Illinois, under GRI Contract No. 5088-271-1680. This report is also cited as GRI Report Number GRI-92/0363. The technical support and guidance of John Gregor, project manager, is gratefully acknowledged. The authors also wish to acknowledge the support and input of the American Gas Association's Gas Metering Research Council (Task Group Number 16 of the Transmission Measurement Committee) as well as the assistance of Mary Yannutz and Nick Sanchez in preparing this report. 
[1] Orifice metering of natural gas and other related hydrocarbon fluids, Part 2 - Specification and installation requirements, A.G.A. Report No. 3-API 14.3, Third Edition, American Gas Association, Arlington, Virginia; February 1991.

[2] Measurement of fluid flow by means of orifice plates, nozzles and venturi tubes inserted in circular cross-section conduits running full, International Standard ISO 5167, First Edition, International Organization for Standardization; (1980).

[3] Orifice metering of natural gas and other related hydrocarbon fluids, Part 1 - General equations and uncertainty guidelines, A.G.A. Report No. 3-API 14.3, Third Edition, American Gas Association, Arlington, Virginia; October 1990.

[4] Sindt, C.F., Lewis, M.A., and Brennan, J.A., Orifice meter performance downstream of a tube bundle flow conditioner, elbows, and a tee. Natl. Inst. Stand. Tech. Tech. Note $1344 ; 1990$.

[5] Gallagher, J.E., The A.G.A. Report No. 3 orifice plate discharge coefficient equation, Second International Symposium on Fluid Flow Measurement, Calgary, Alberta, Canada; June 6-8, 1990.

[6] McFaddin, S.E., Sindt, C.F., and Brennan, J.A., Optimum location of flow conditioners in a 4-inch orifice meter, Natl. Inst. Stand. Tech. Tech. Note $1330 ; 1989$.

[7] Scott, J.L., Sindt, C.F., Lewis, M.A., and Brennan, J.A., The effects of flow conditioners and tap location on orifice flowmeter performance, Natl. Inst. Stand. Tech. Tech. Note 1352; 1991.

[8] McKee, R.J., and Sparks, C.R., GRI Metering Research Facility update, 26 th Annual Gulf Coast Measurement Short Course, Houston, Texas; September 1991.

[9] Park, J.T., and Morrow, T.B., Orifice meter installation effects: sliding vane test with a 17D meter tube and a 19-tube bundle straightening vane downstream of a tee. GRI Technical Memorandum MRF-UE05, SWRI, San Antonio, Texas; April 1992.

[10] Morrow, T.B., and Park, J.T., Orifice meter installation effects: sliding vane test with a 17D meter tube and a 7 tube bundle straightening vane downstream of a tee. GRI Technical Memorandum MRF-UE07, SWRI, San Antonio, Texas; April 1992.

[11] Mattingly, G.E., and Yeh, T.T., Summary report of NIST's industrygovernment consortium research program on flowmeter installation effects with emphasis on research period May 1989-Feb. 1990: Tube bundle effects. Natl. Inst. Stand. Tech. NISTIR 4751; 1991.

[12] Mattingly, G.E., and Yeh, T.T., Summary report of NIST's industrygovernment consortium research program on flowmeter installation effects with emphasis on research period Feb.-Dec. 1990: Tee, used as an elbow configuration. Natl. Inst. Stand. Tech. NISTIR 4753; 1992. 


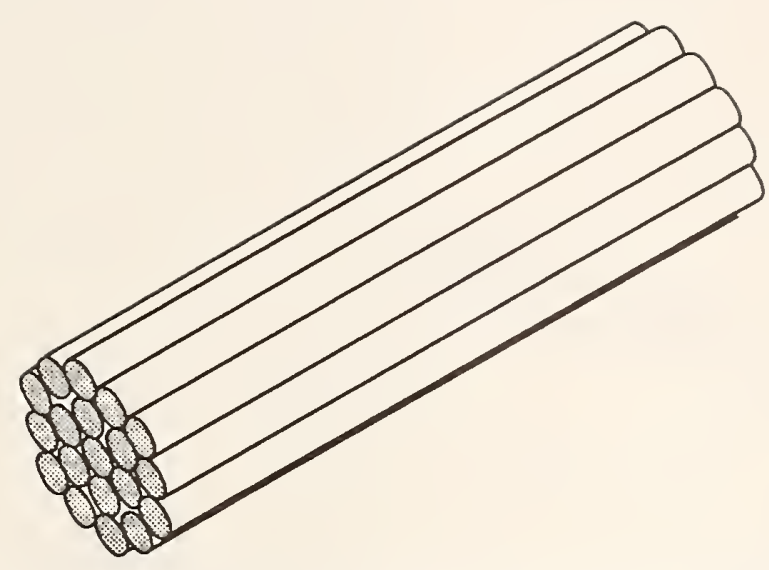

Figure 1a. In-line, 19 tube bundle flow conditioner.

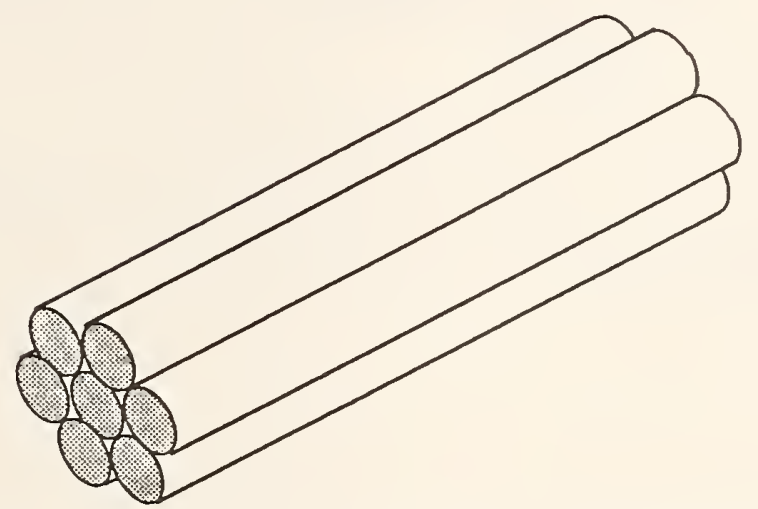

Figure 1b. In-line, 7 tube bundle flow conditioner.

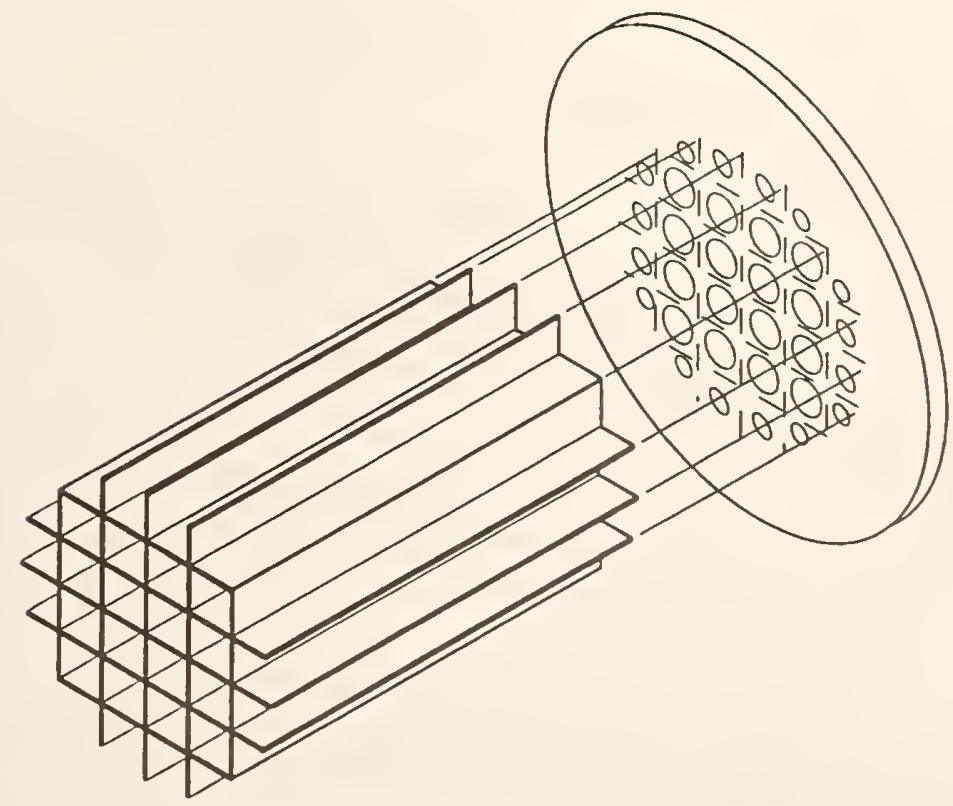

Figure 1c. Zanker flow conditioner 


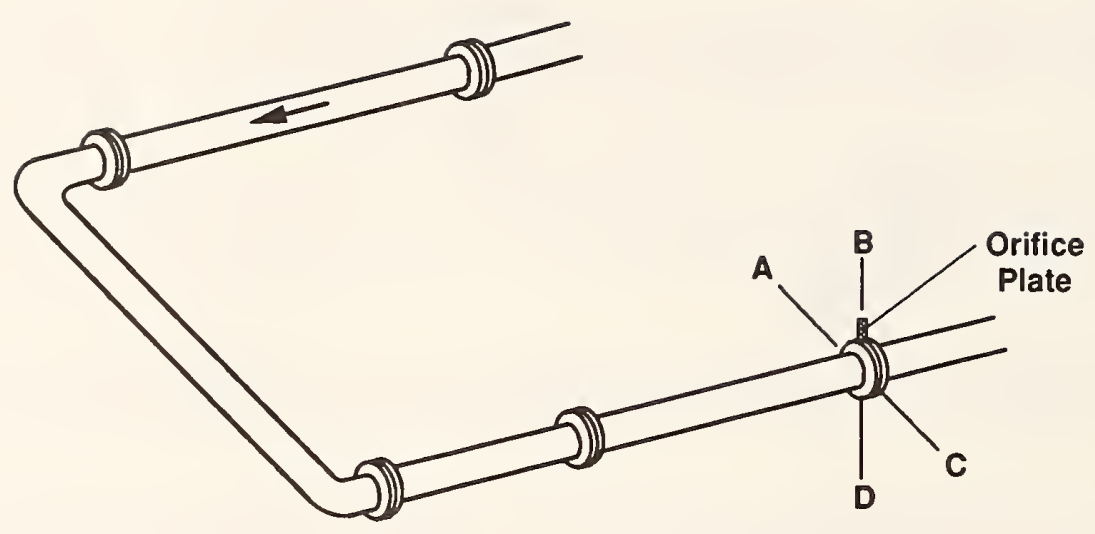

Figure 2. Flange pressure tap position code.

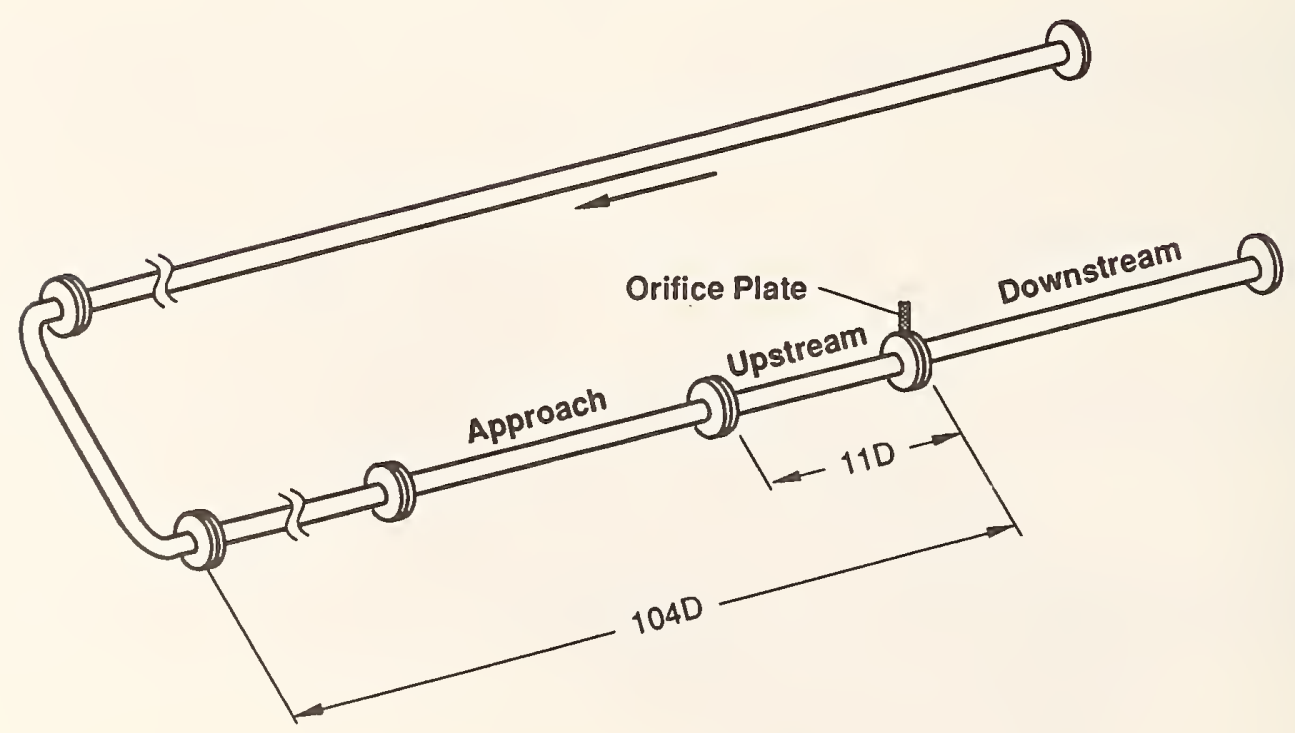

Figure 3. Baseline configuration, $104 \mathrm{~mm}$ (4 in) orifice meter. 


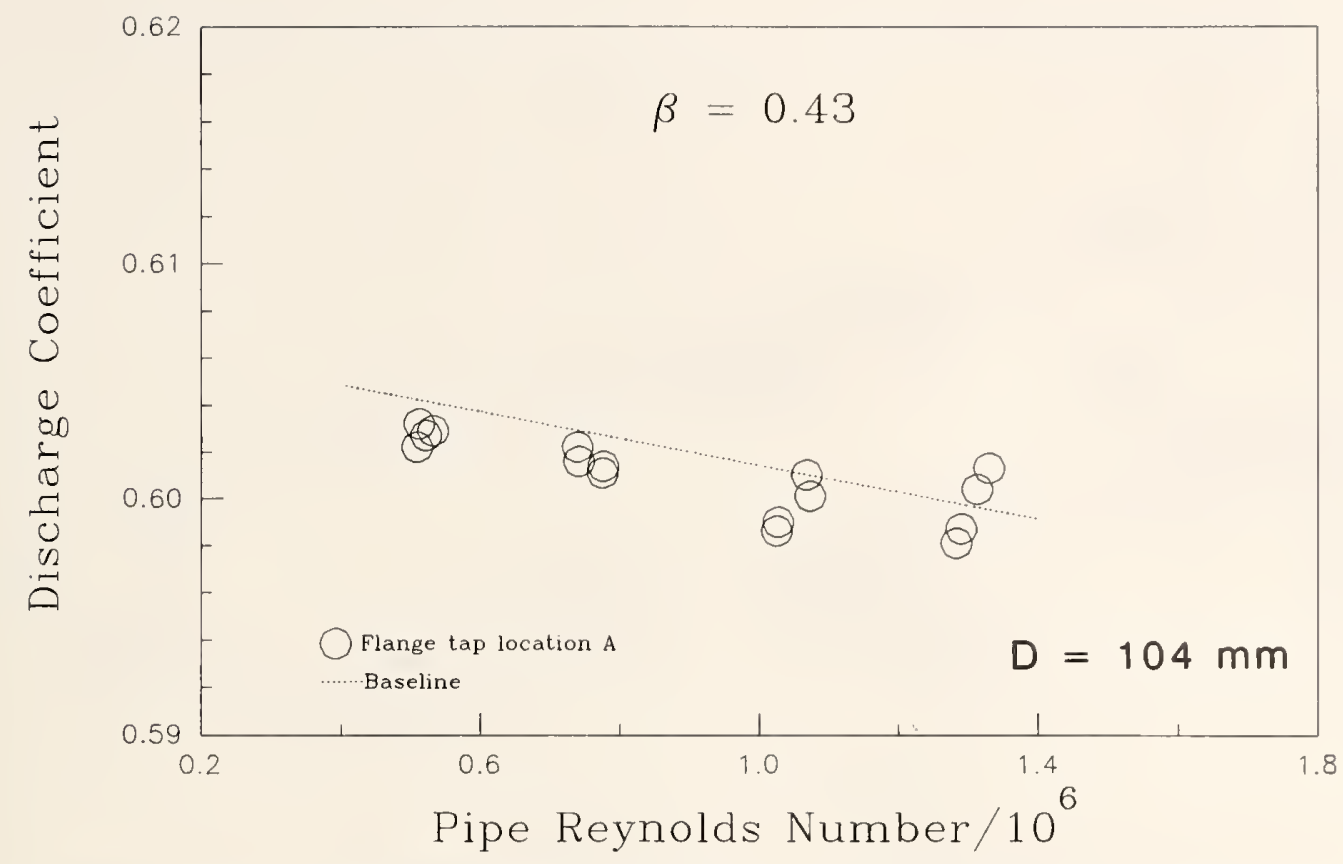

Figure 4. Discharge coefficient vs. Reynolds number for the 0.43 beta ratio plate with an elbow and $104 \mathrm{D}$ straight pipe.

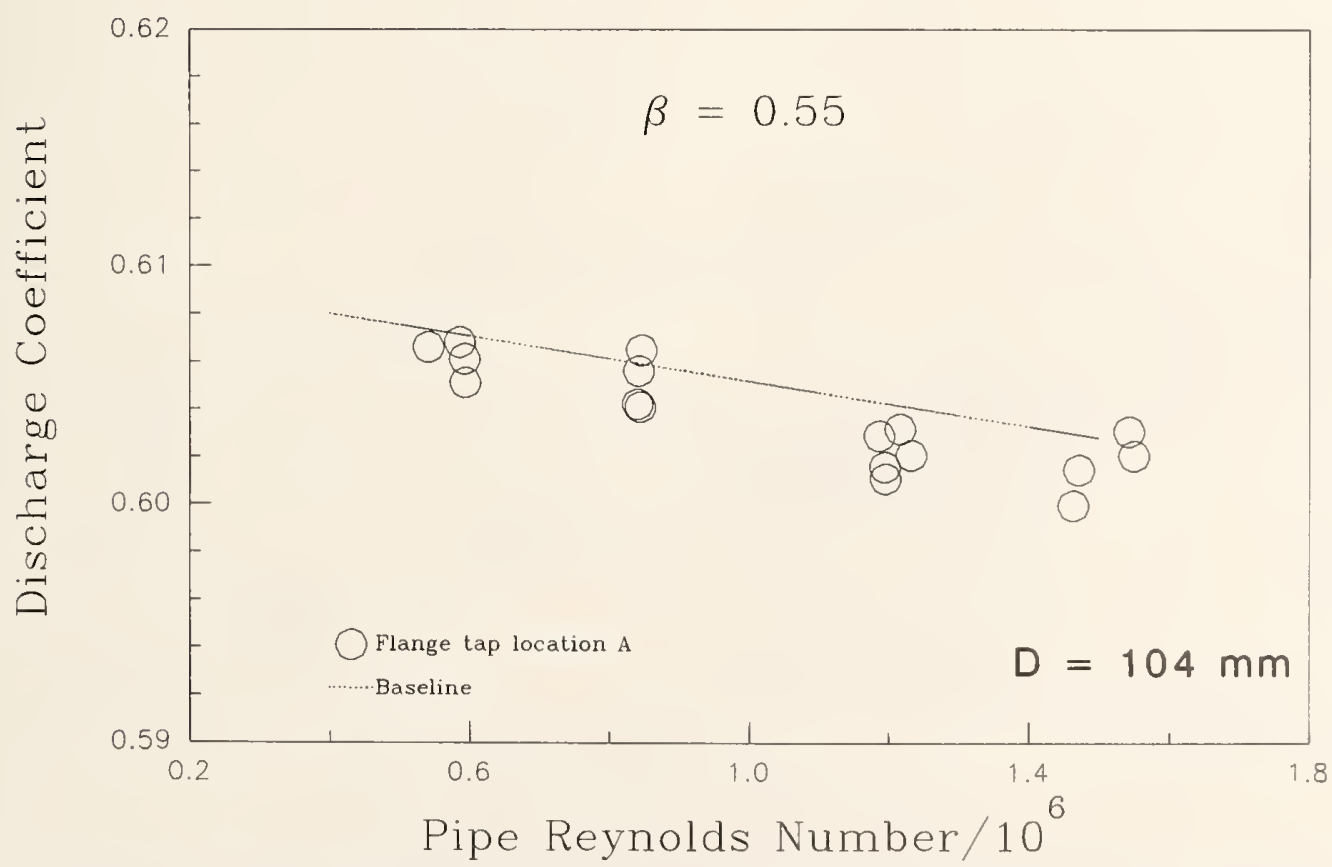

Figure 5. Discharge coefficient vs. Reynolds number for the 0.55 beta ratio plate with an elbow and 104D straight pipe. 


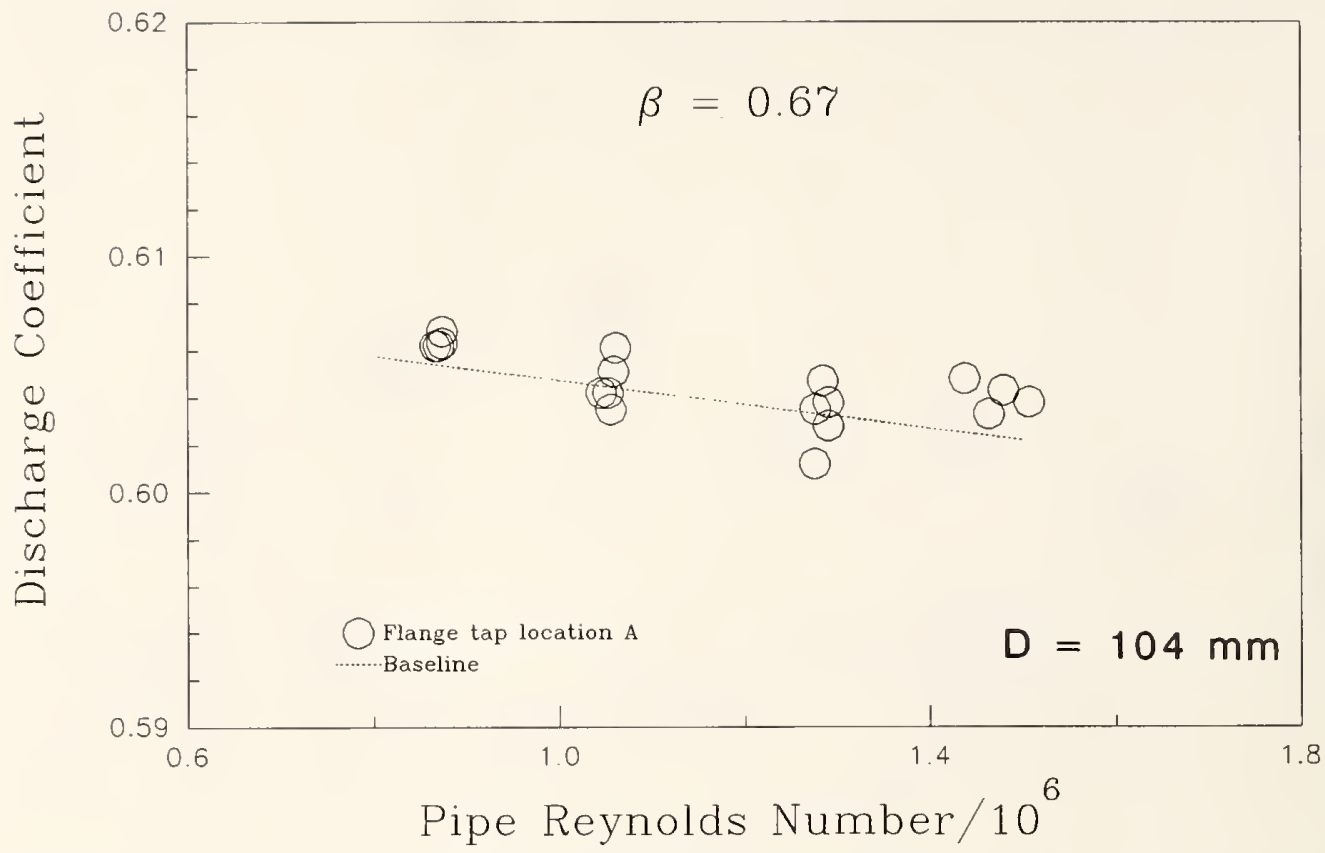

Figure 6. Discharge coefficient vs. Reynolds number for the 0.67 beta ratio plate with an elbow and 104D straight pipe.

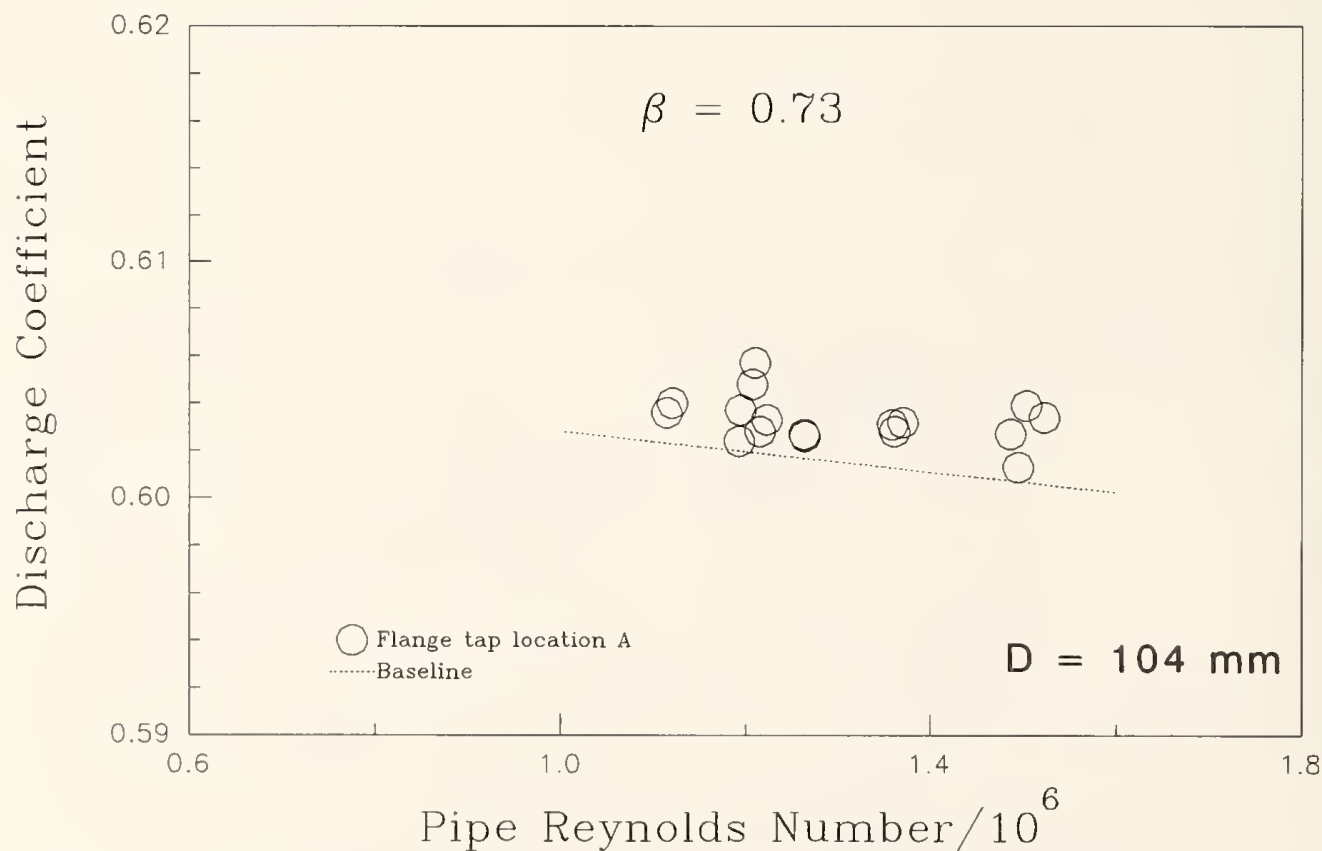

Figure 7. Discharge coefficient vs. Reynolds number for the 0.73 beta ratio plate with an elbow and 104D straight pipe. 


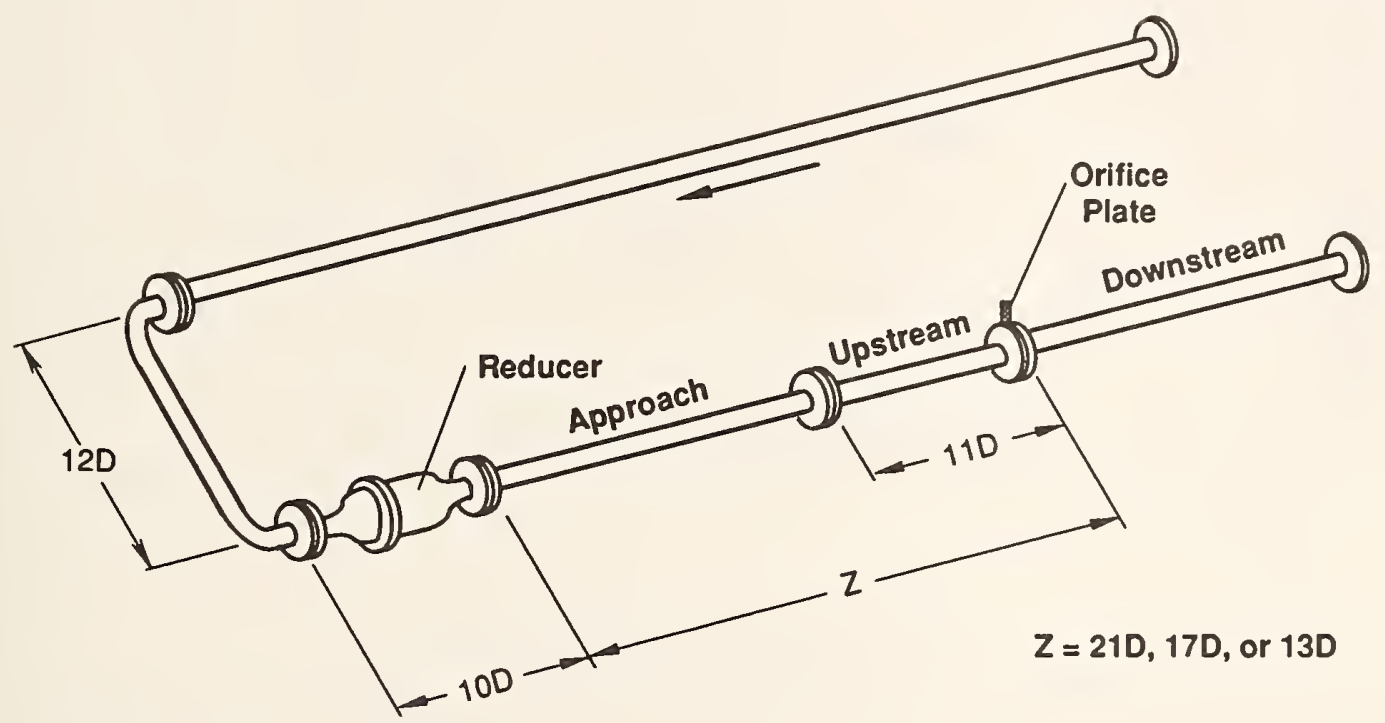

Figure 8. 'Test configuration, $104 \mathrm{~mm}$ (4 in) orifice meter, reducer disturbance.

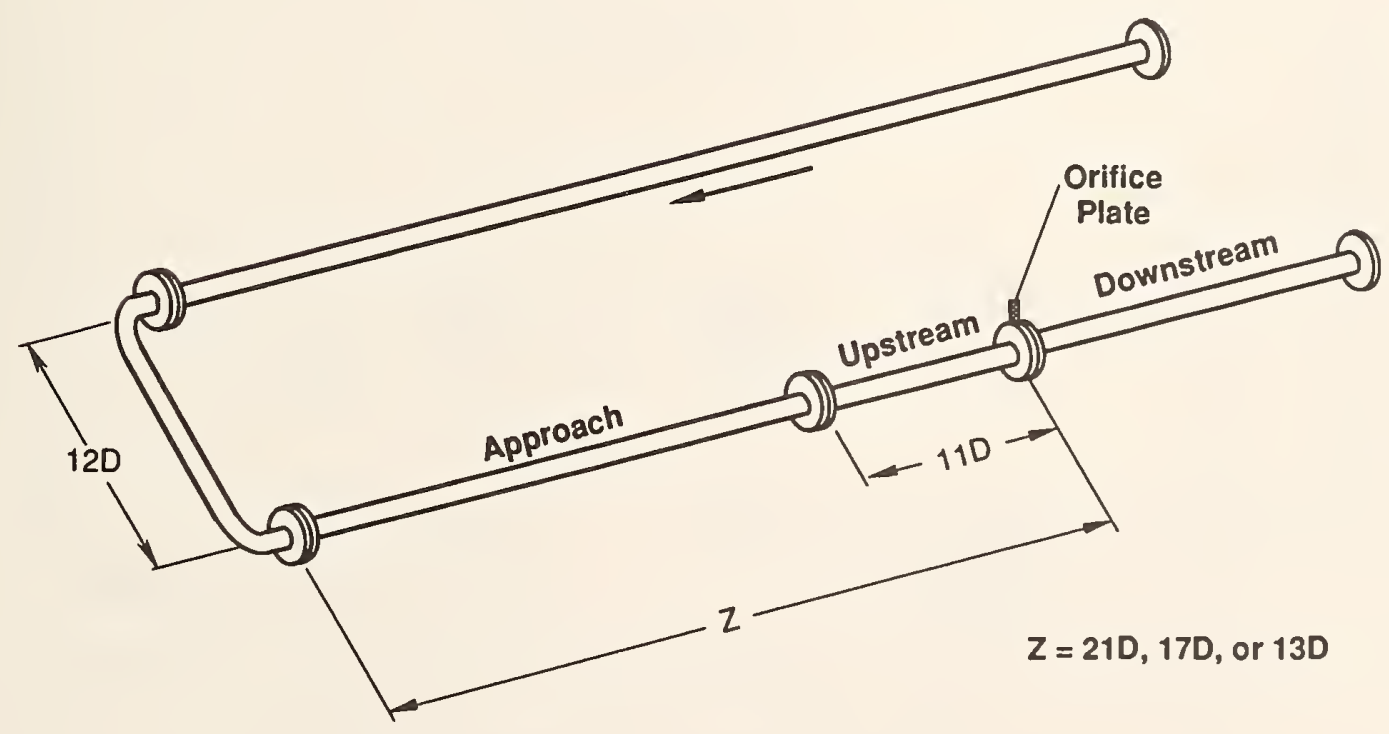

Figure 9. Test configuration, $104 \mathrm{~mm}$ (4 in) orifice meter, elbow disturbance. 


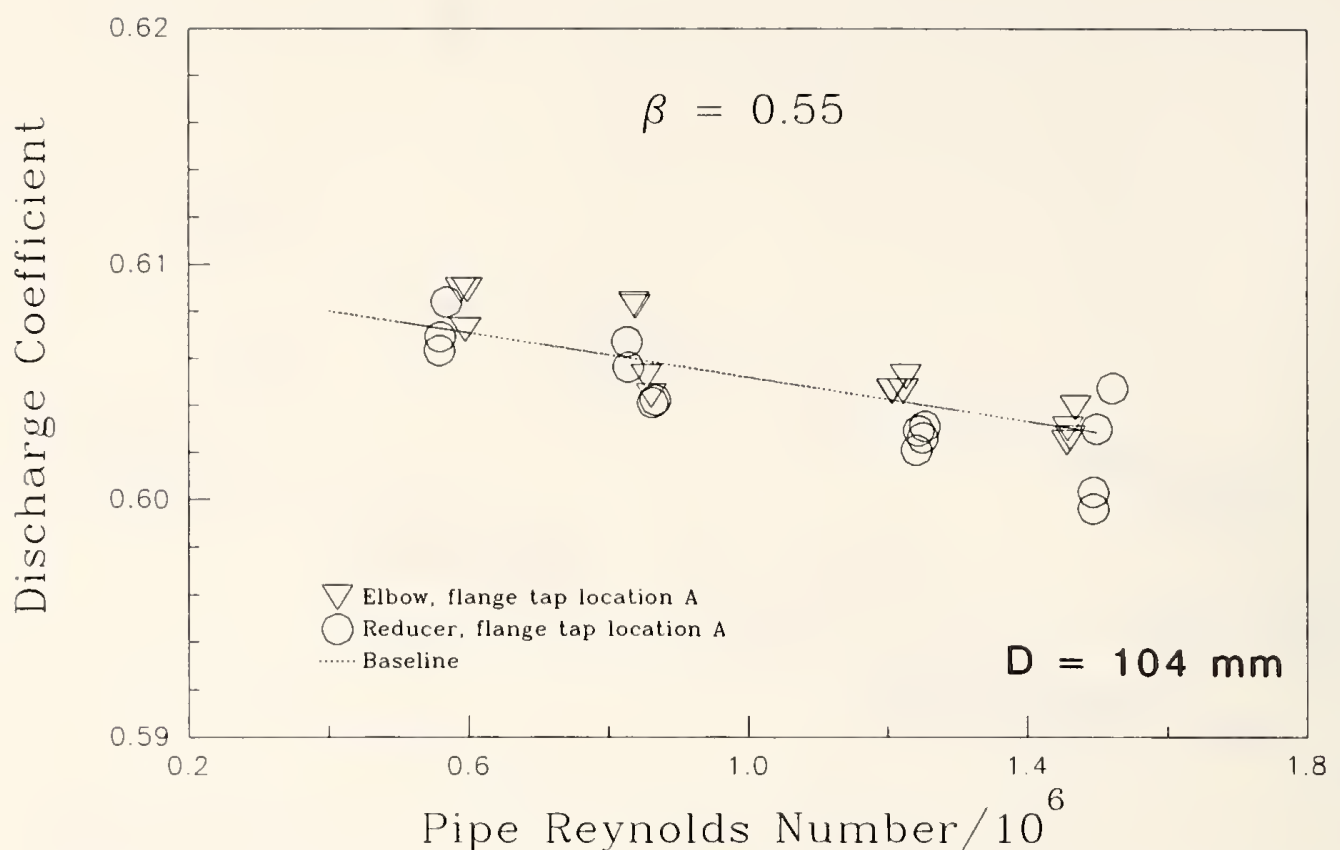

Figure 10. Discharge coefficient vs. Reynolds number for the 0.55 beta ratio plate with a reducer or elbow at $21 \mathrm{D}$, in-line, 19 tube bundle at $19 \mathrm{D}$

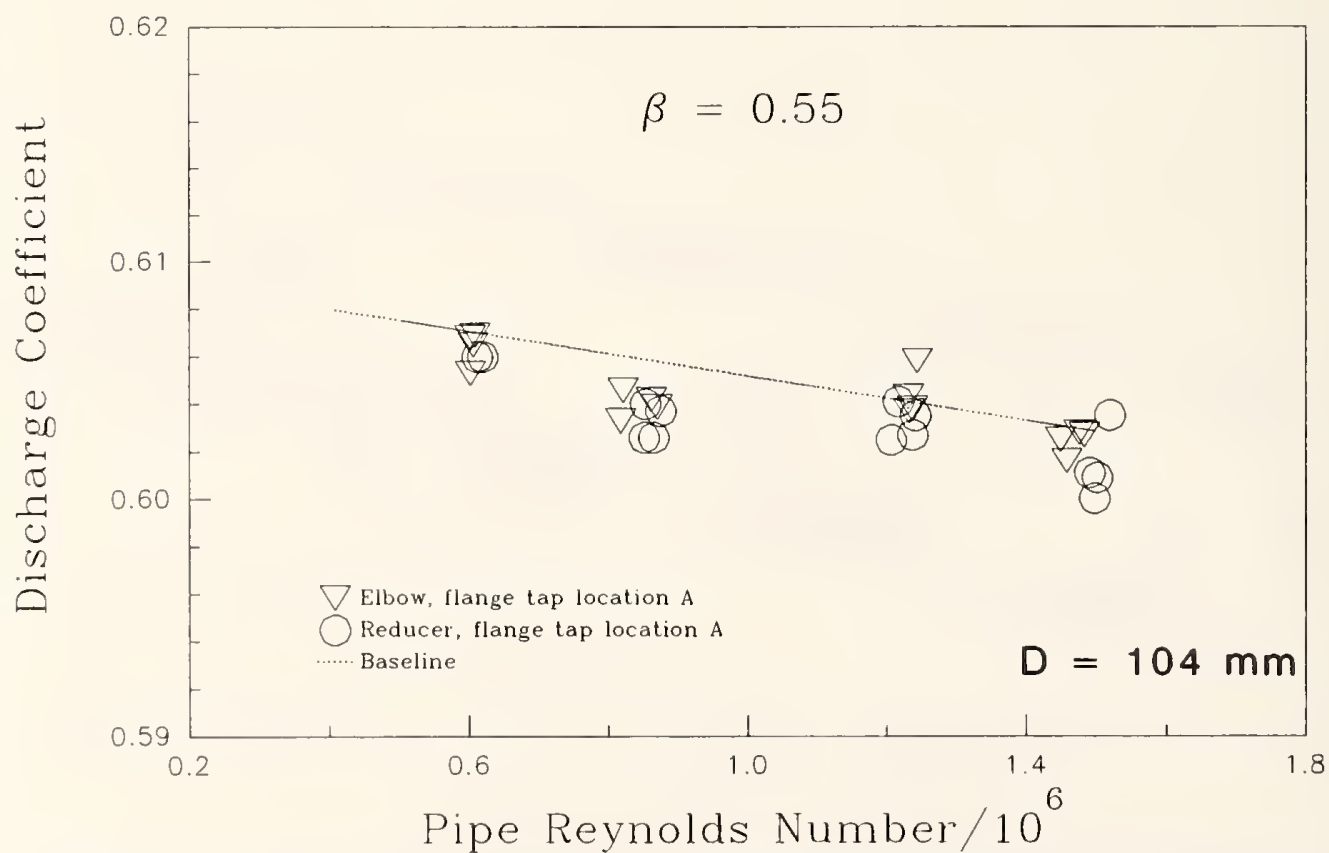

Figure 11. Discharge coefficient vs. Reynolds number for the 0.55 beta ratio plate with a reducer or elbow at $17 \mathrm{D}$, in-line, 19 tube bundle at $15 \mathrm{D}$. 


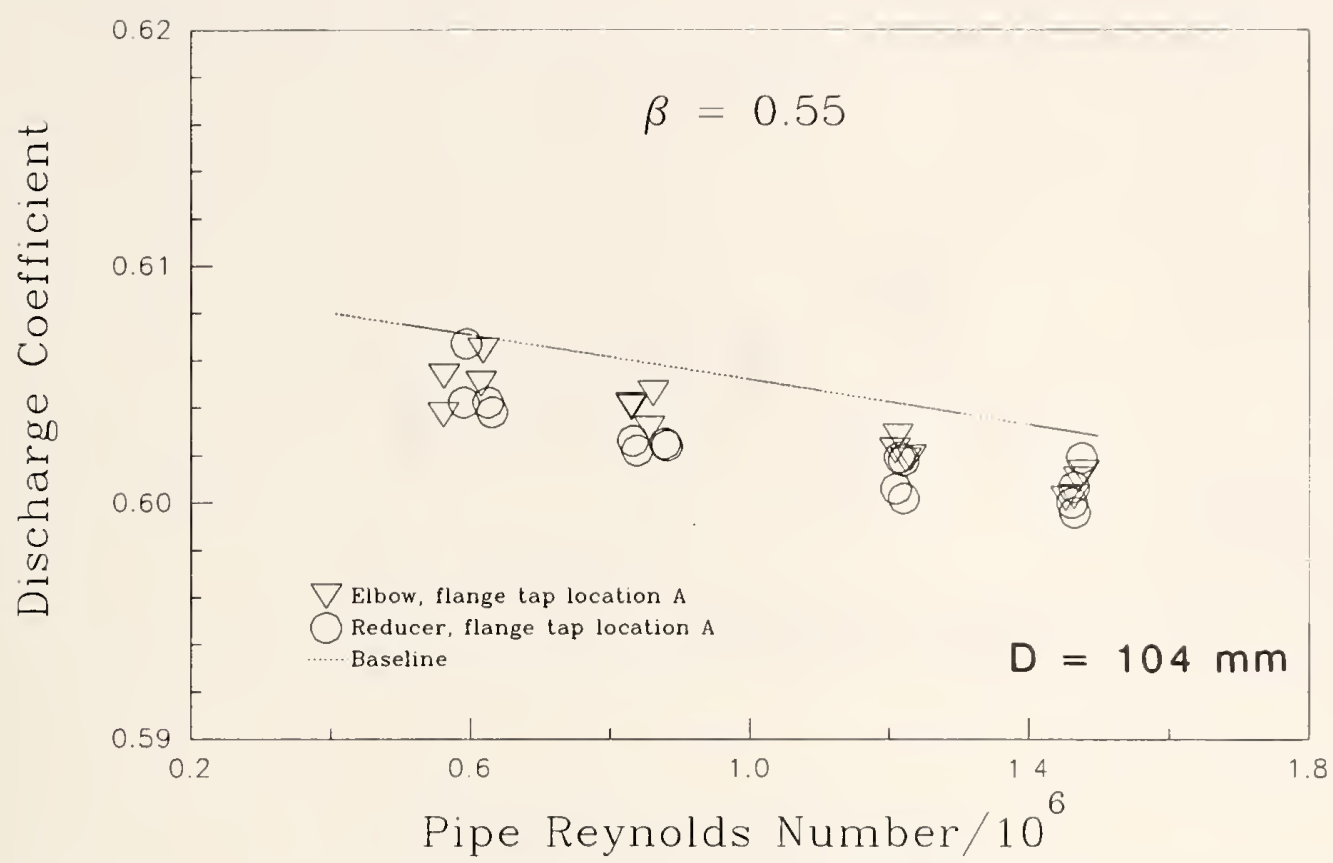

Figure 12. Discharge coefficient vs. Reynolds number for the 0.55 beta ratio plate with a reducer or elbow at $13 \mathrm{D}$, in-line, 19 tube bundle at $11 \mathrm{D}$.

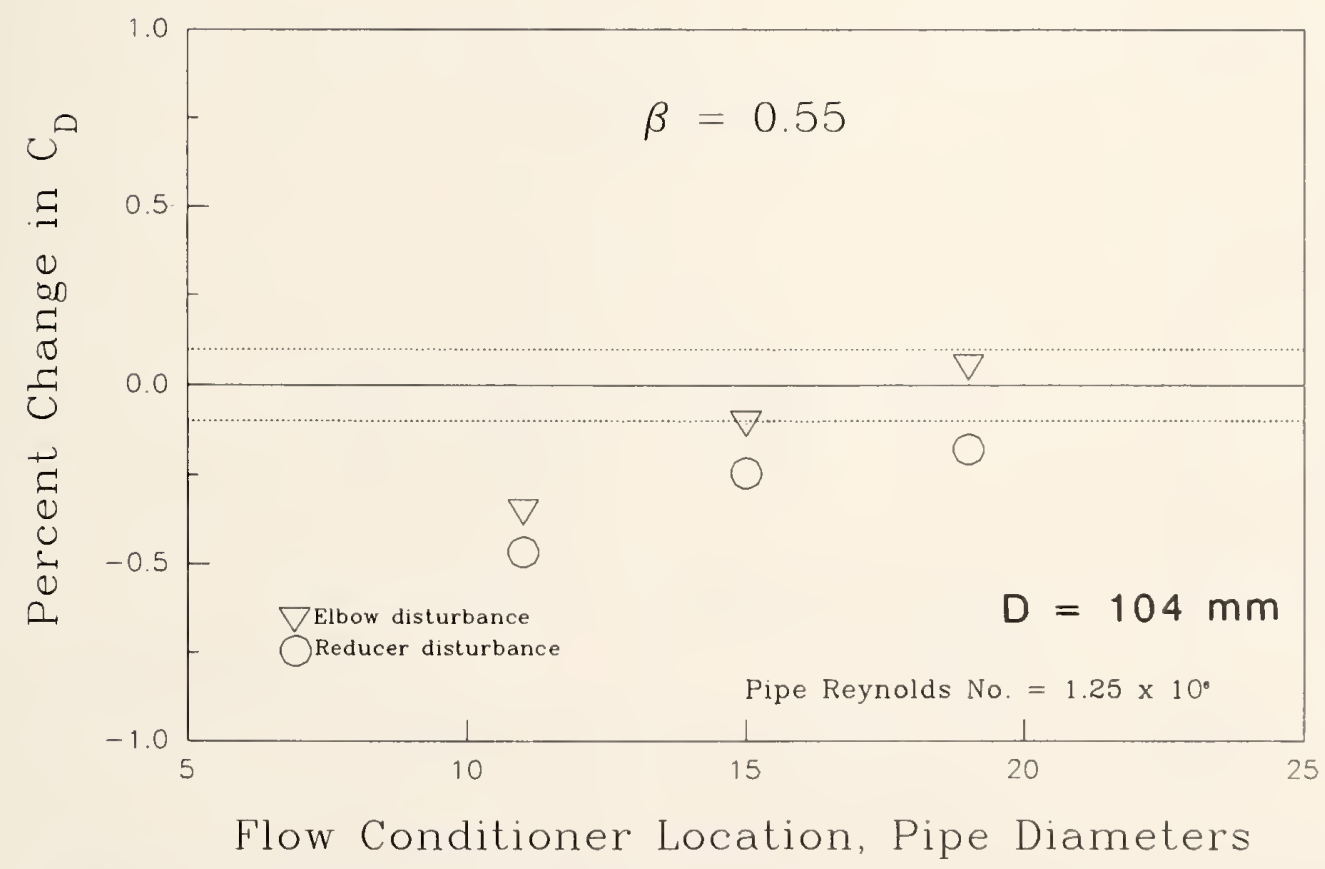

Figure 13. Percent change in discharge coefficient vs. disturbance location for the 0.55 beta ratio plate and a reducer or elbow disturbance. 


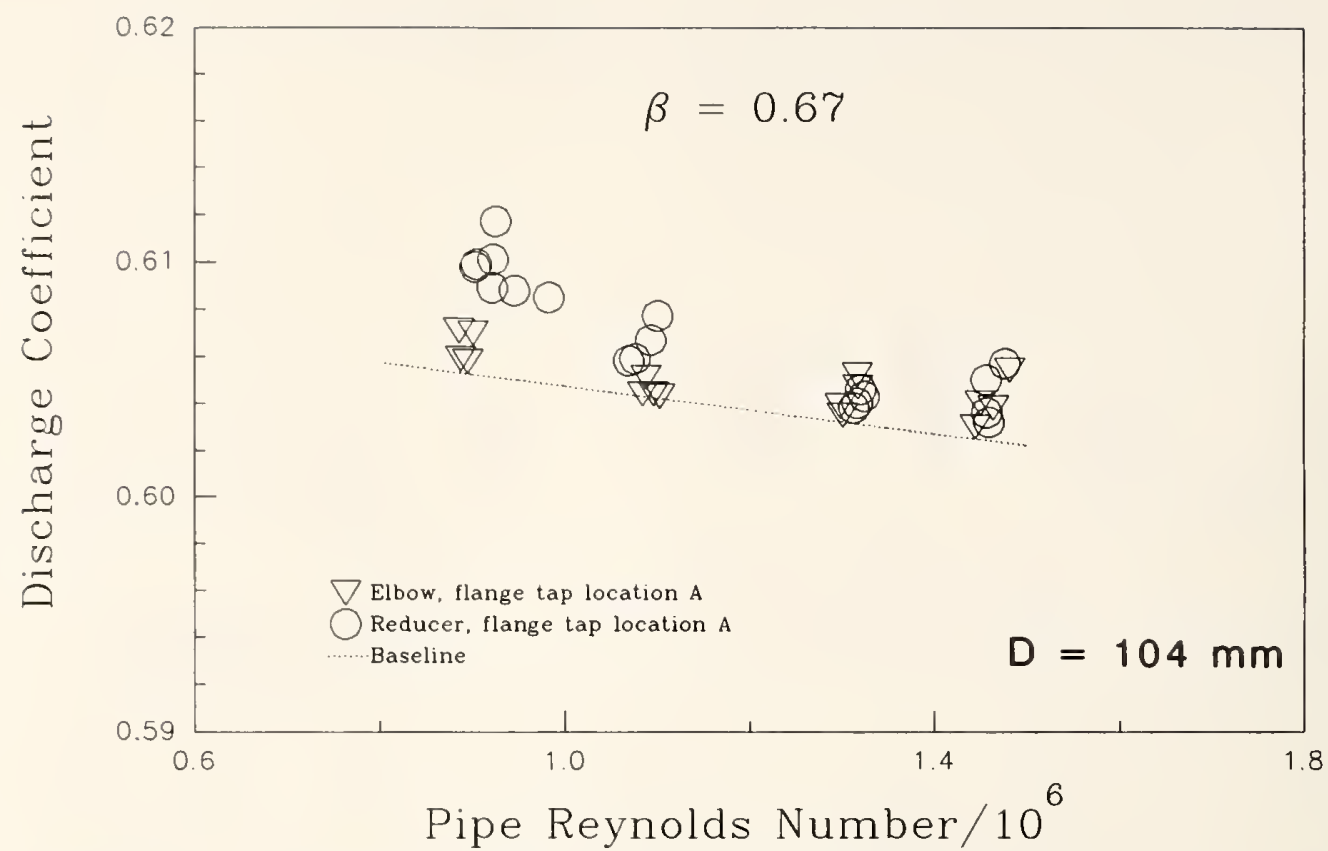

Figure 14. Discharge coefficient vs. Reynolds number for the 0.67 beta ratio plate with a reducer or elbow at $21 \mathrm{D}$, in-line, 19 tube bundle at $19 \mathrm{D}$

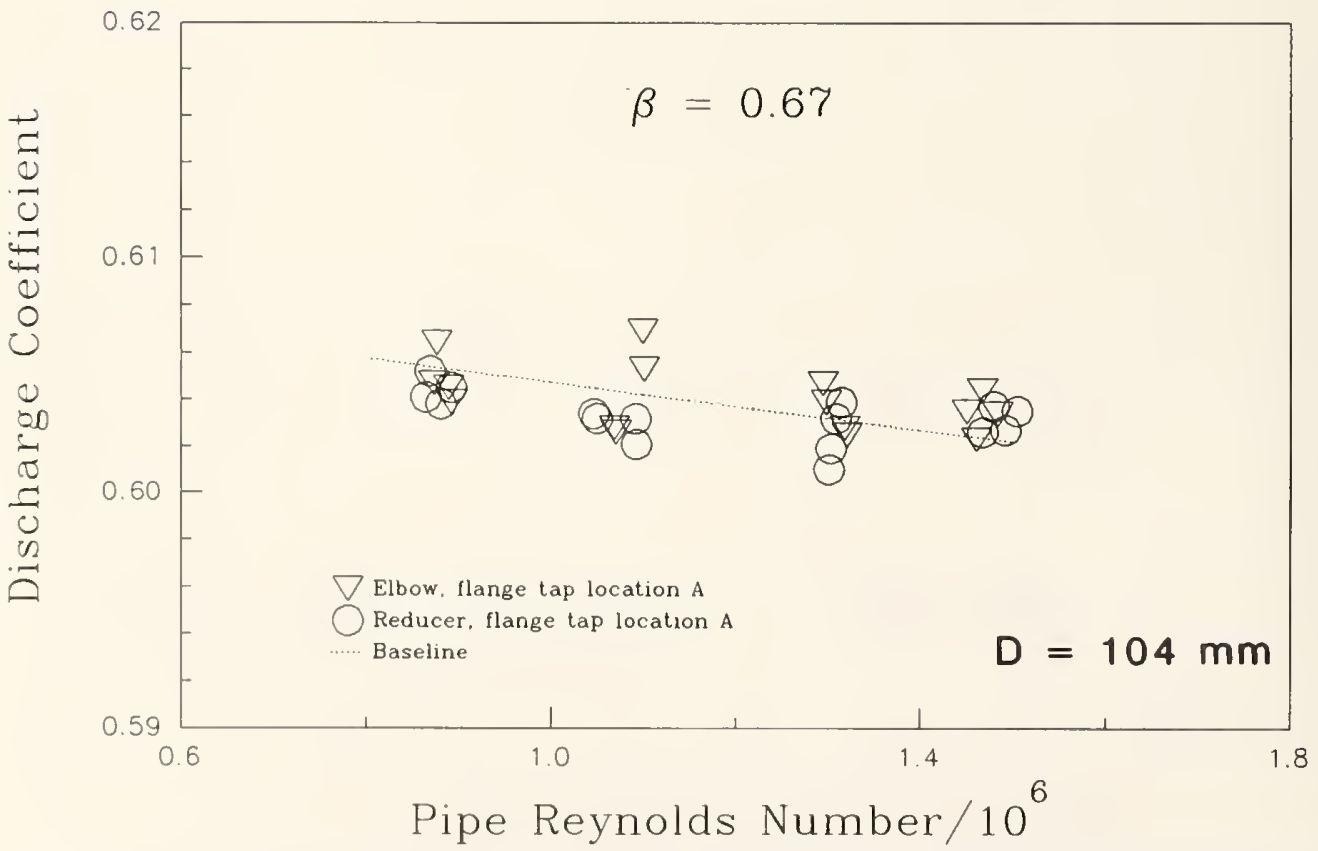

Figure 15. Discharge coefficient vs. Reynolds number for the 0.67 beta ratio plate with a reducer or elbow at 17D, in-line, 19 tube bundle at $15 \mathrm{D}$. 


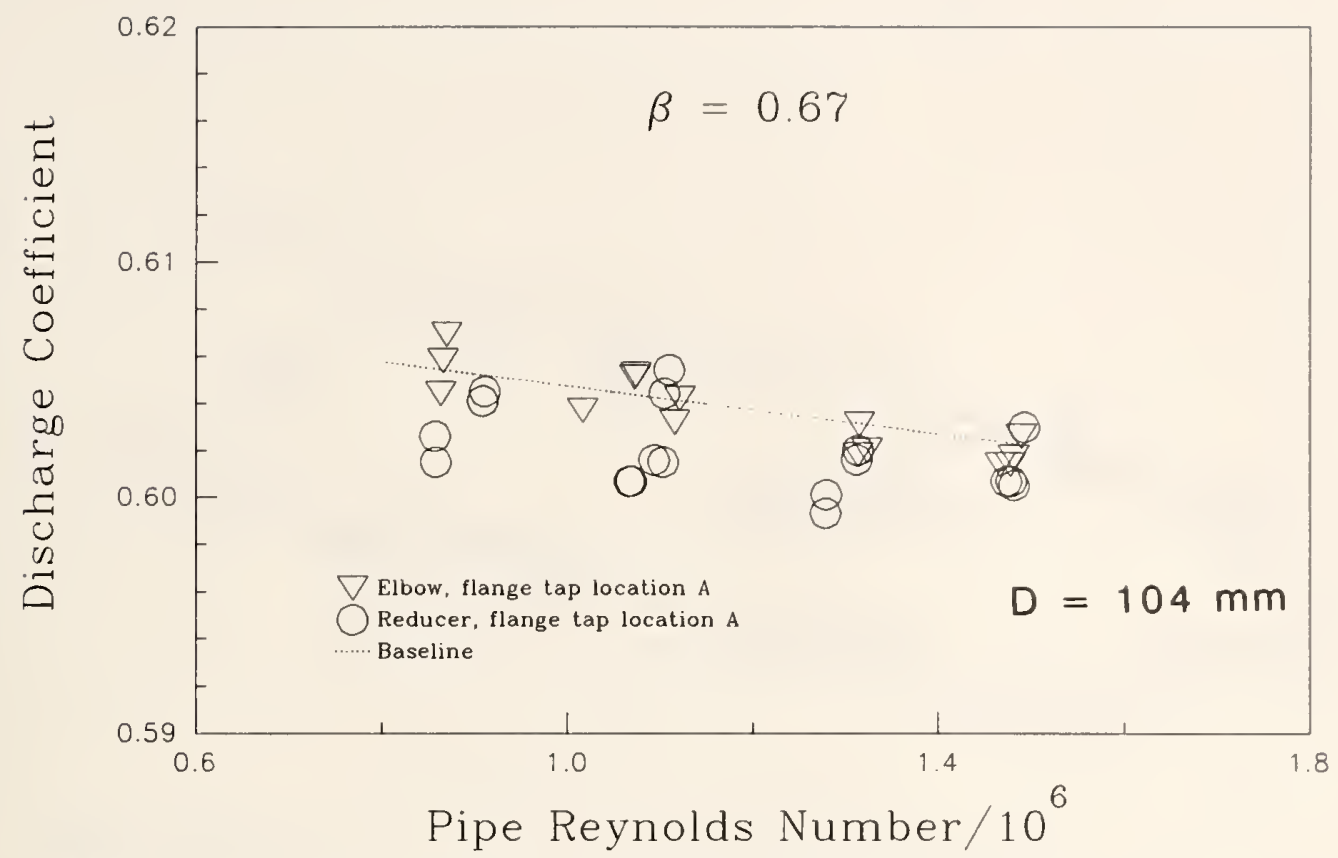

Figure 16. Discharge coefficient vs. Reynolds number for the 0.67 beta ratio plate with a reducer or elbow at 13D, in-line, 19 tube bundle at $11 \mathrm{D}$.

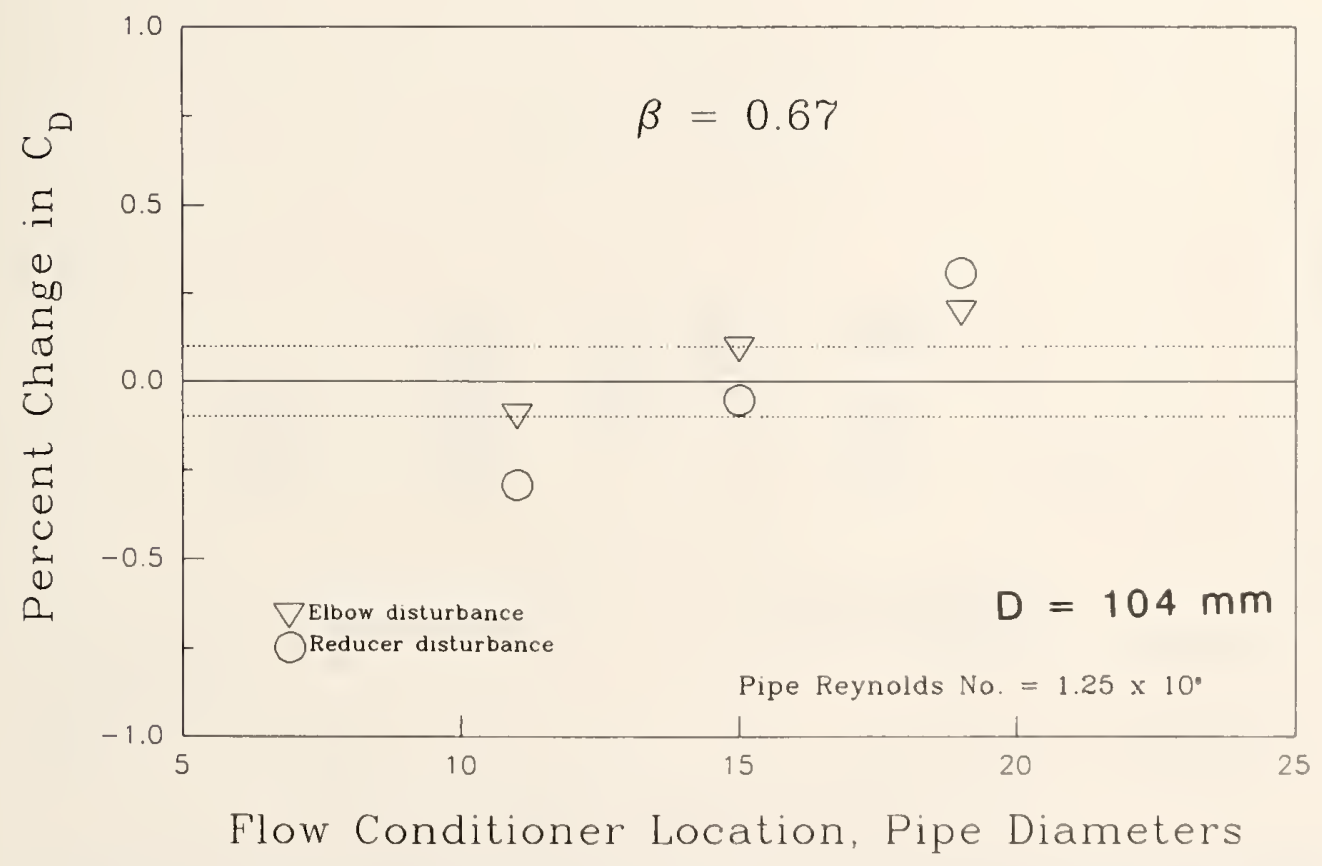

Figure 17. Percent change in discharge coefficient vs. disturbance location for the 0.67 beta ratio plate and a reducer or elbow disturbance. 


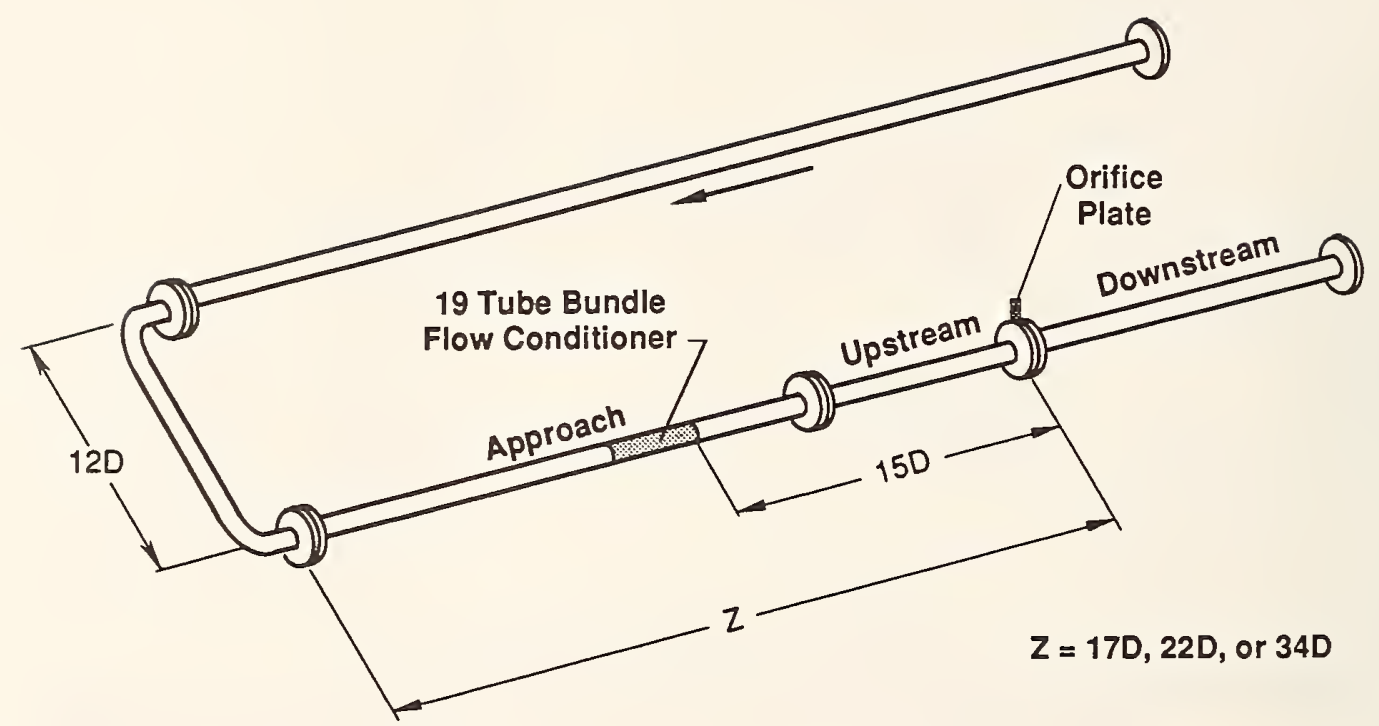

Figure 18. Test configuration, $104 \mathrm{~mm}$ (4 in) orifice meter, elbow disturbance.

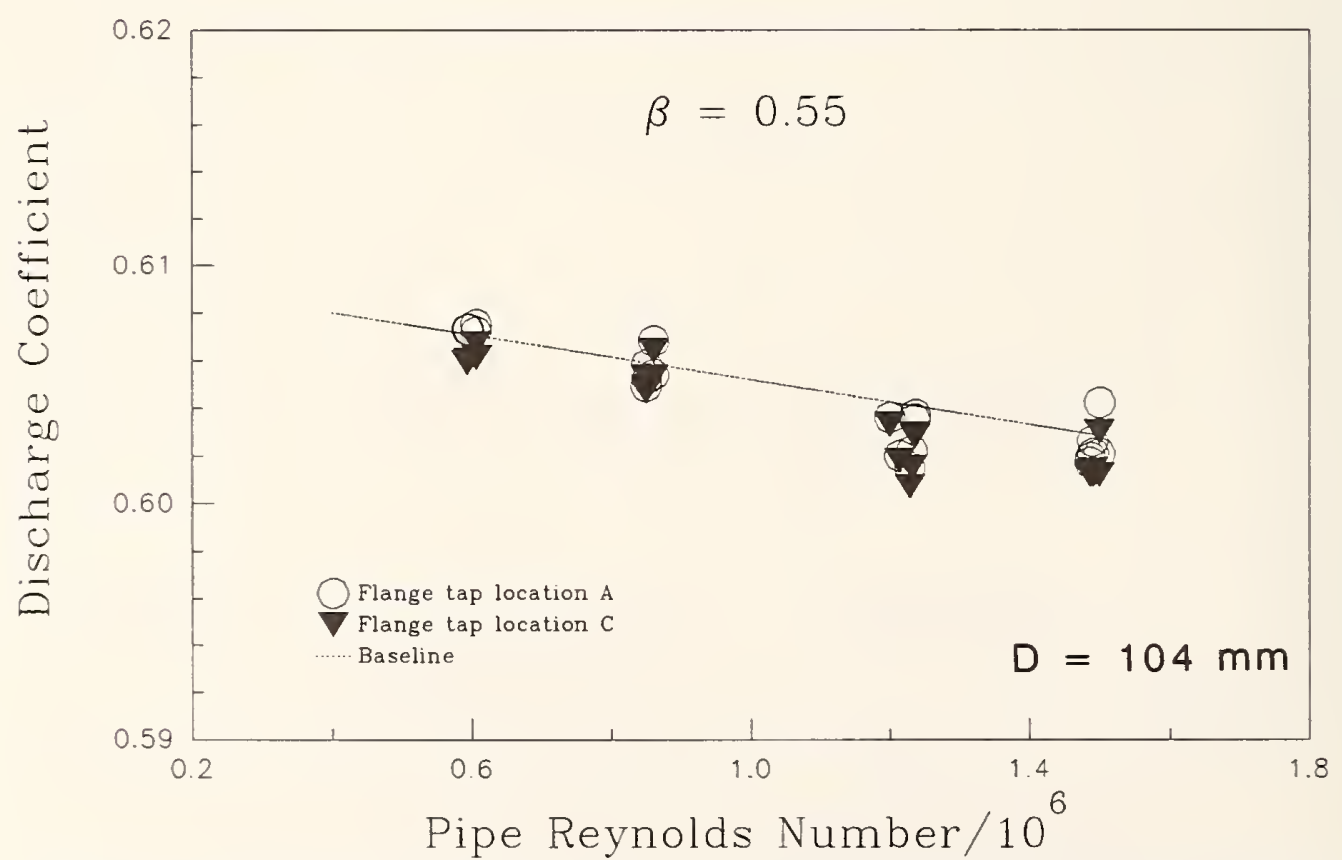

Figure 19. Discharge coefficient vs. Reynolds number for the 0.55 beta ratio plate with an elbow at $17 \mathrm{D}$, an in-line, 19 tube bundle at 15D, and 2 flange tap locations. 


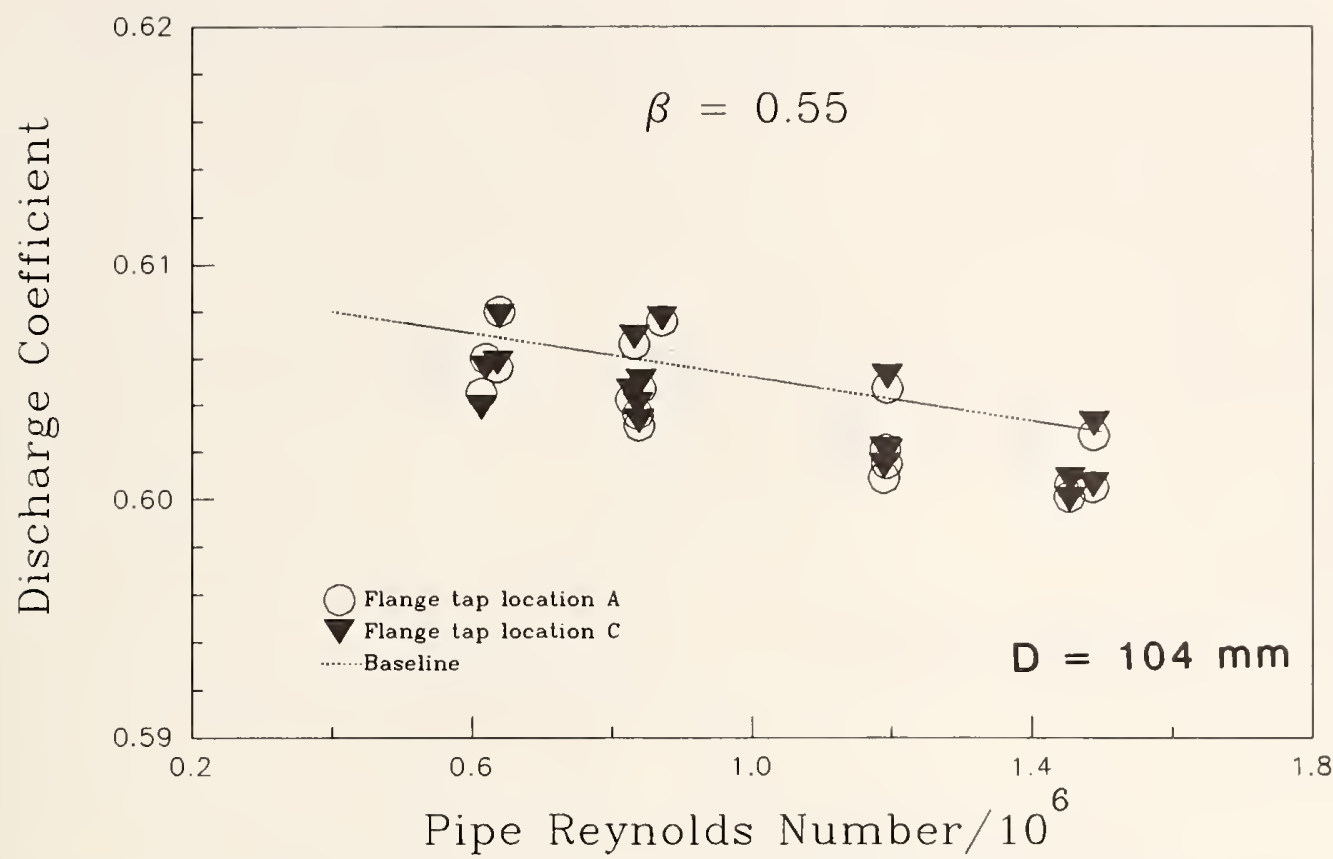

Figure 20. Discharge coefficient vs. Reynolds number for the 0.55 beta ratio plate with an elbow at 22D, an in-line, 19 tube bundle at $15 \mathrm{D}$, and 2 flange tap locations.

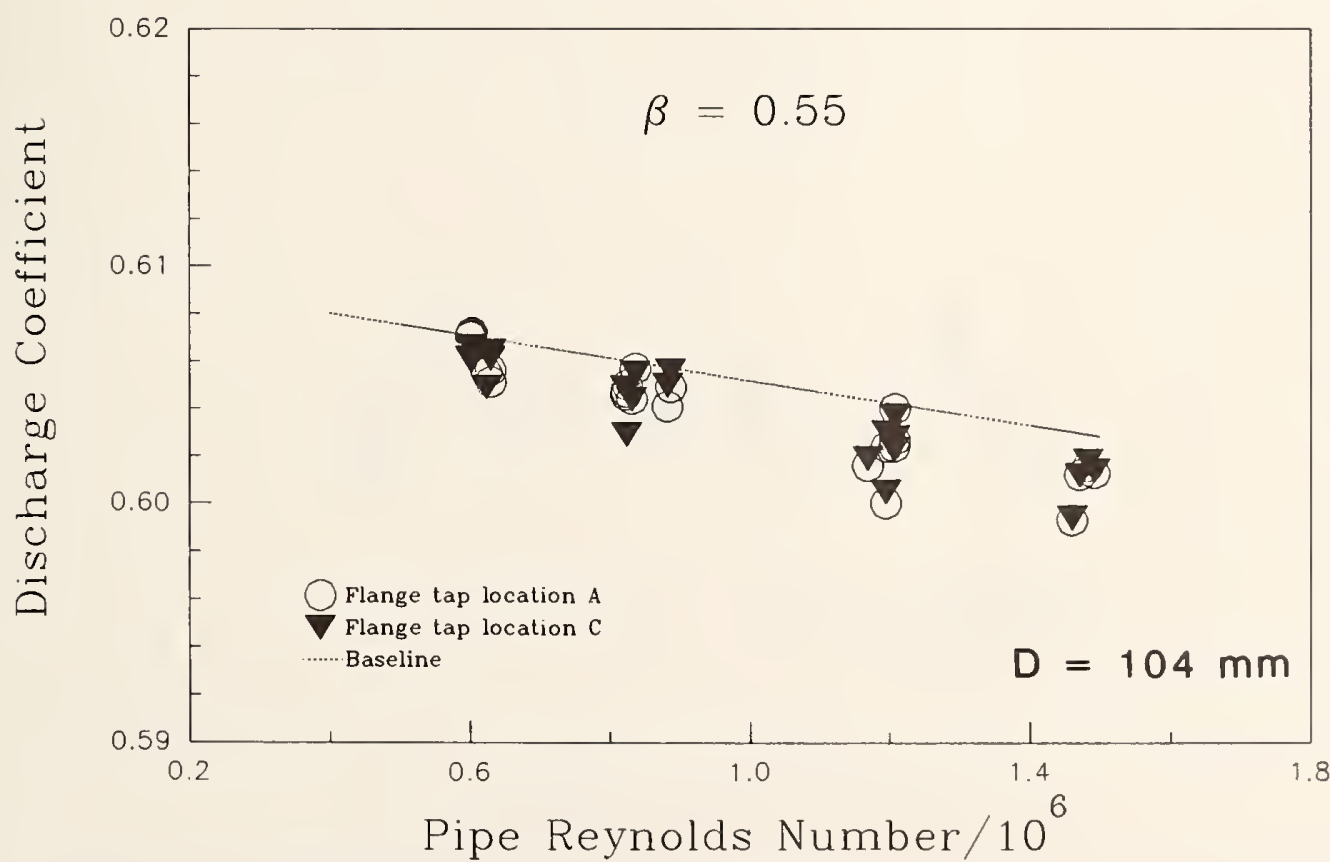

Figure 21. Discharge coefficient vs. Reynolds number for the 0.55 beta ratio plate with an elbow at $34 \mathrm{D}$, an in-line, 19 tube bundle at $15 \mathrm{D}$, and 2 flange tap locations. 


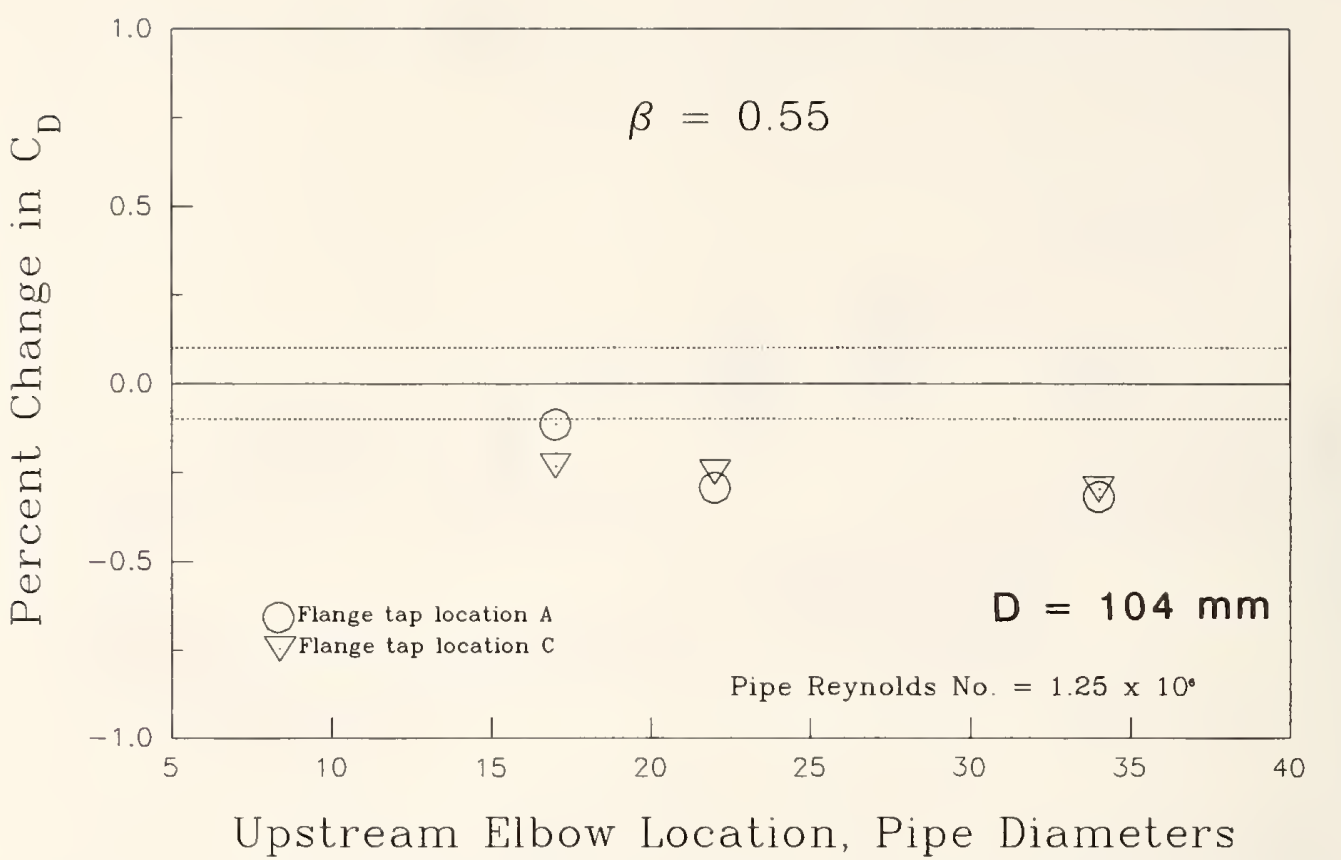

Figure 22. Percent change in discharge coefficient vs. elbow location for the 0.55 beta ratio plate with an in-line, 19 tube bundle at $15 \mathrm{D}$ and 2 flange tap locations.

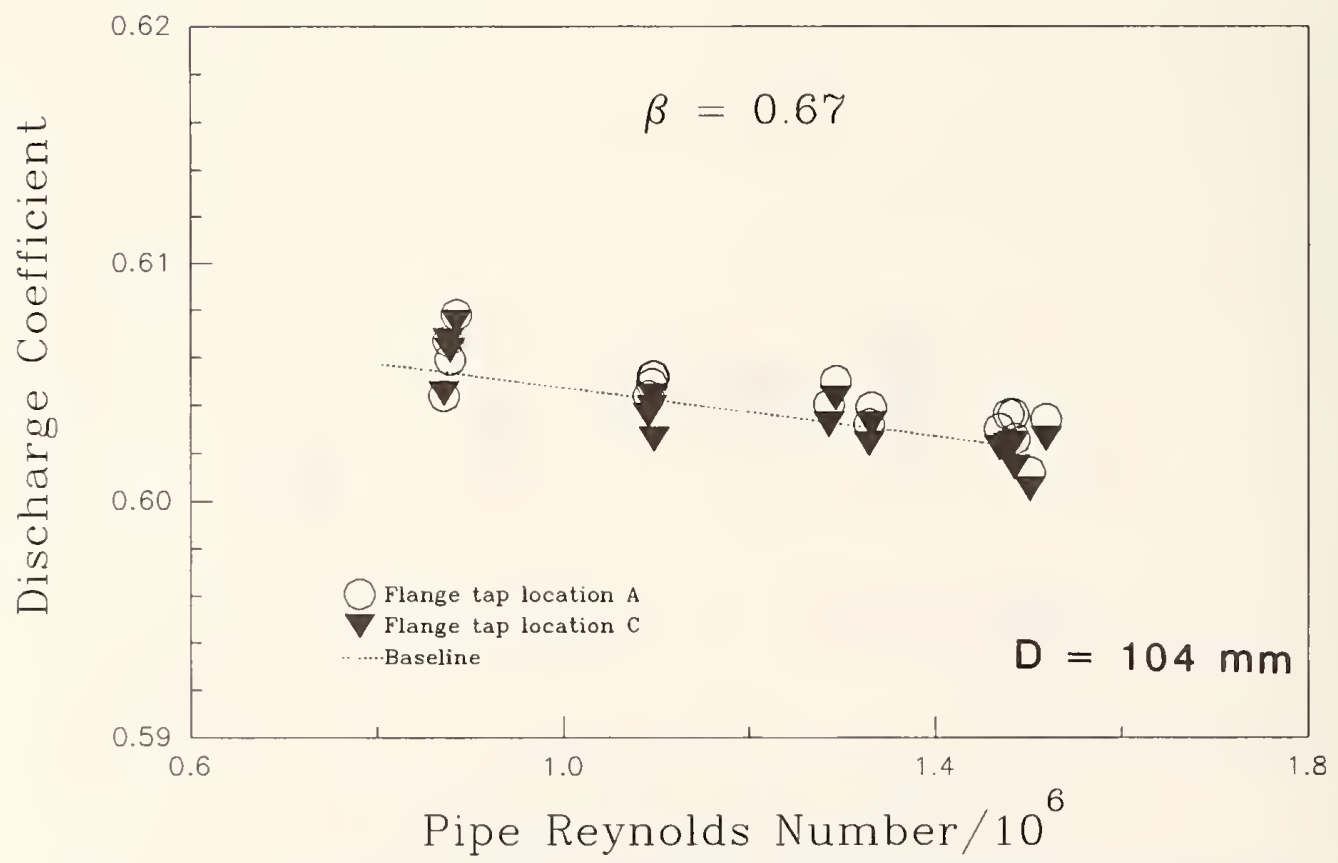

Figure 23. Discharge coefficient vs. Reynolds number for the 0.67 beta ratio plate with an elbow at $17 \mathrm{D}$, an in-line, 19 tube bundle at $15 \mathrm{D}$, and 2 flange tap locations. 


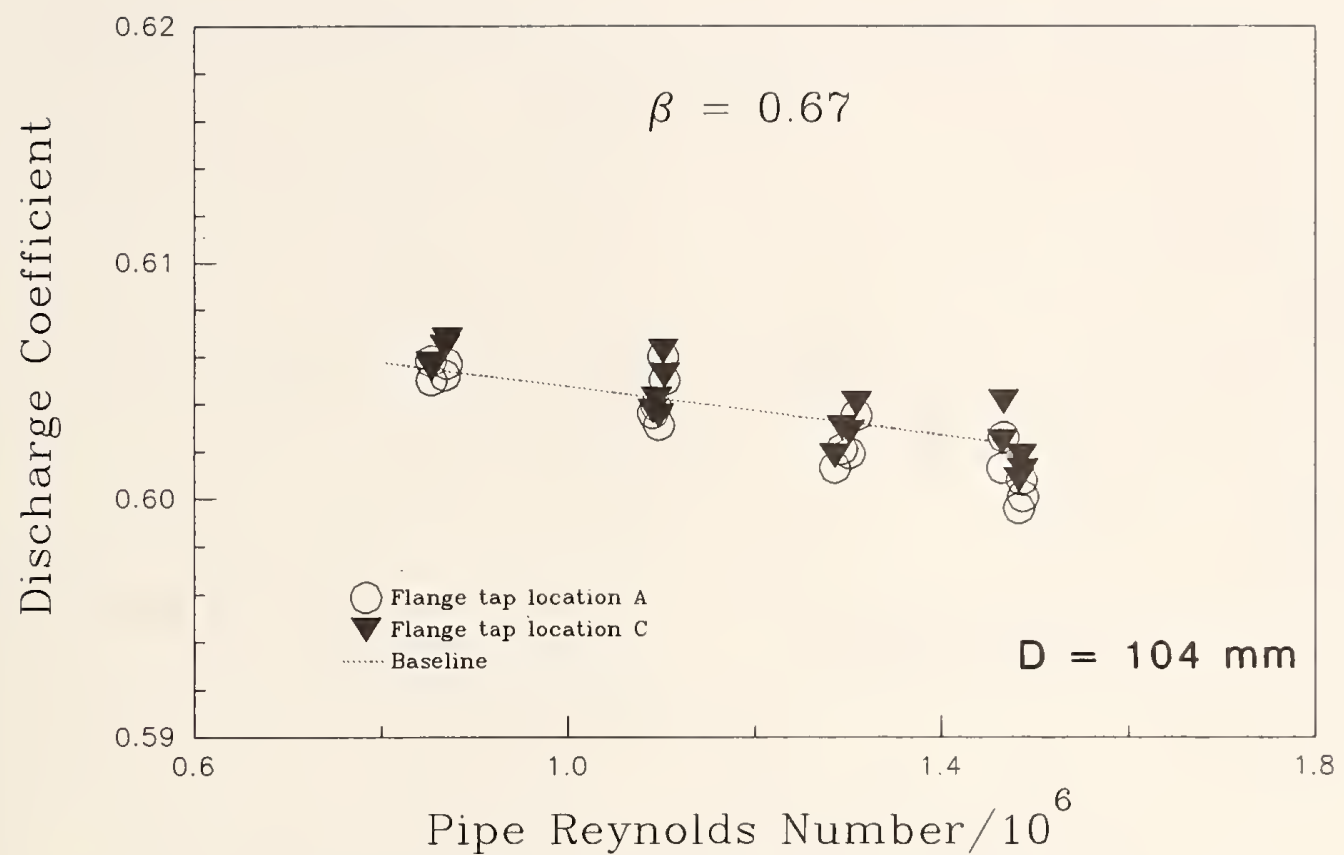

Figure 24. Discharge coefficient vs. Reynolds number for the 0.67 beta ratio plate with an elbow at 22D, an in-line, 19 tube bundle at $15 \mathrm{D}$, and 2 flange tap locations.

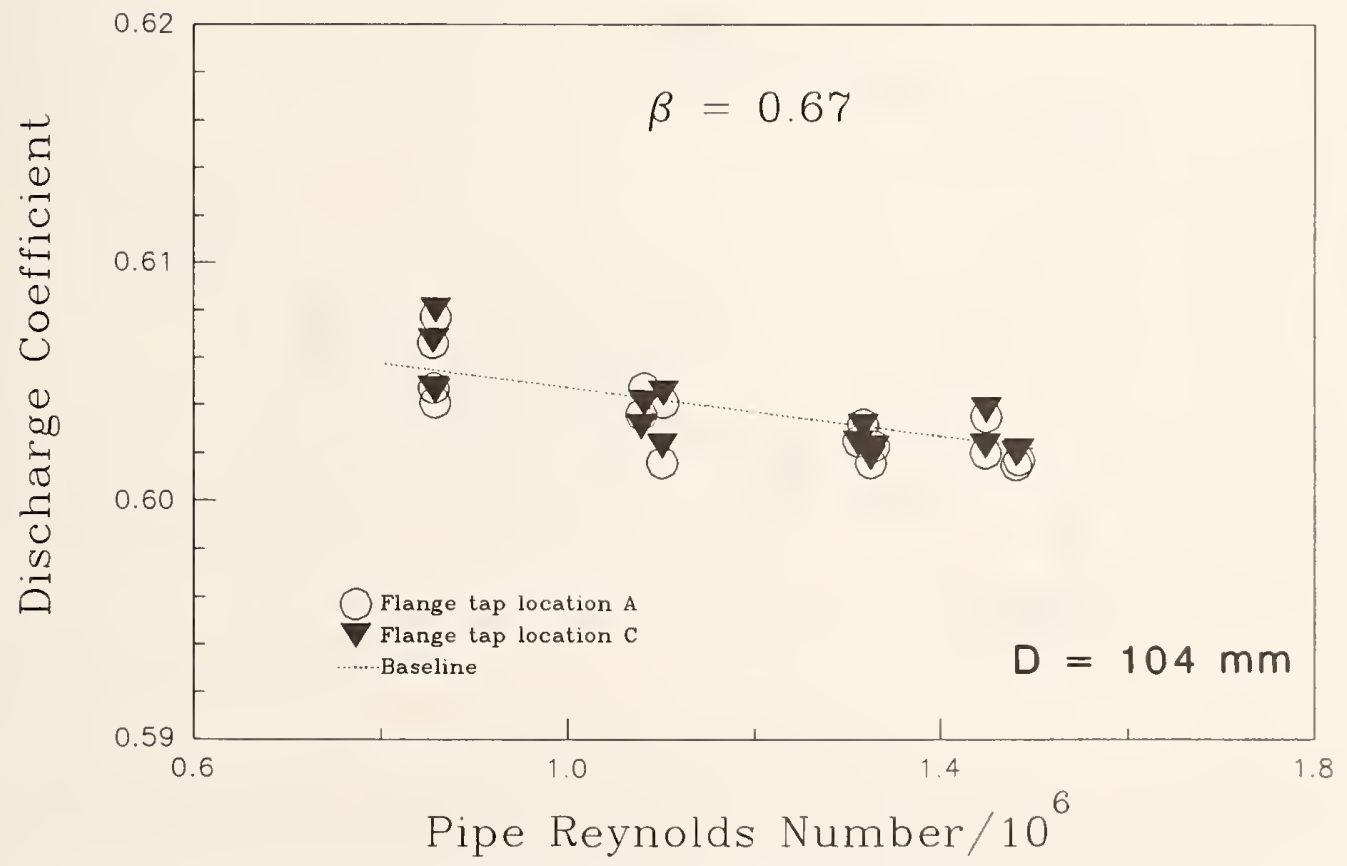

Figure 25. Discharge coefficient vs. Reynolds number for the 0.67 beta ratio plate with an elbow at $34 \mathrm{D}$, an in-line, 19 tube bundle at $15 \mathrm{D}$, and 2 flange tap locations. 


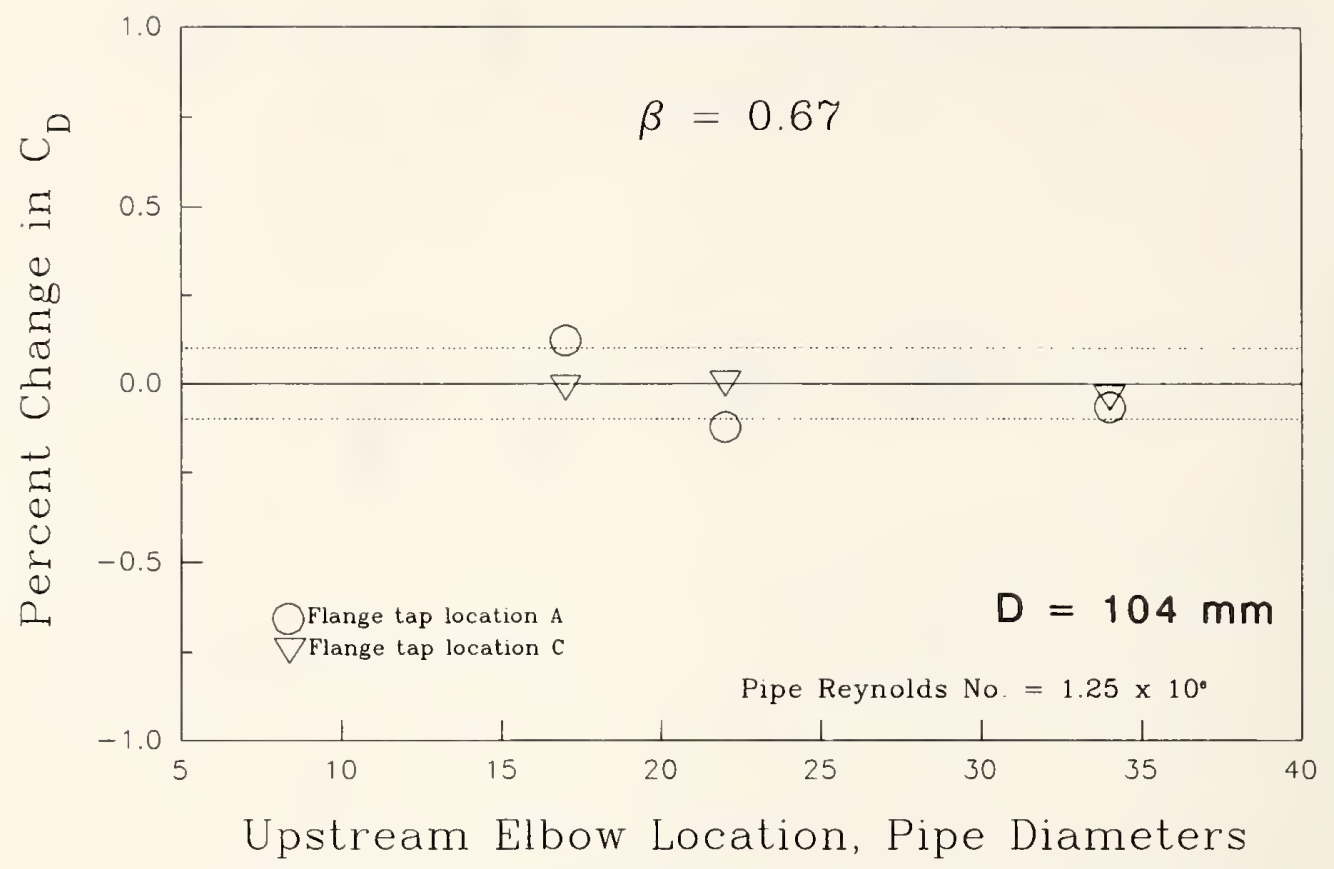

Figure 26. Percent change in discharge coefficient vs. elbow location for the 0.67 beta ratio plate with an in-line, 19 tube bundle at $15 \mathrm{D}$ and 2 flange tap locations.

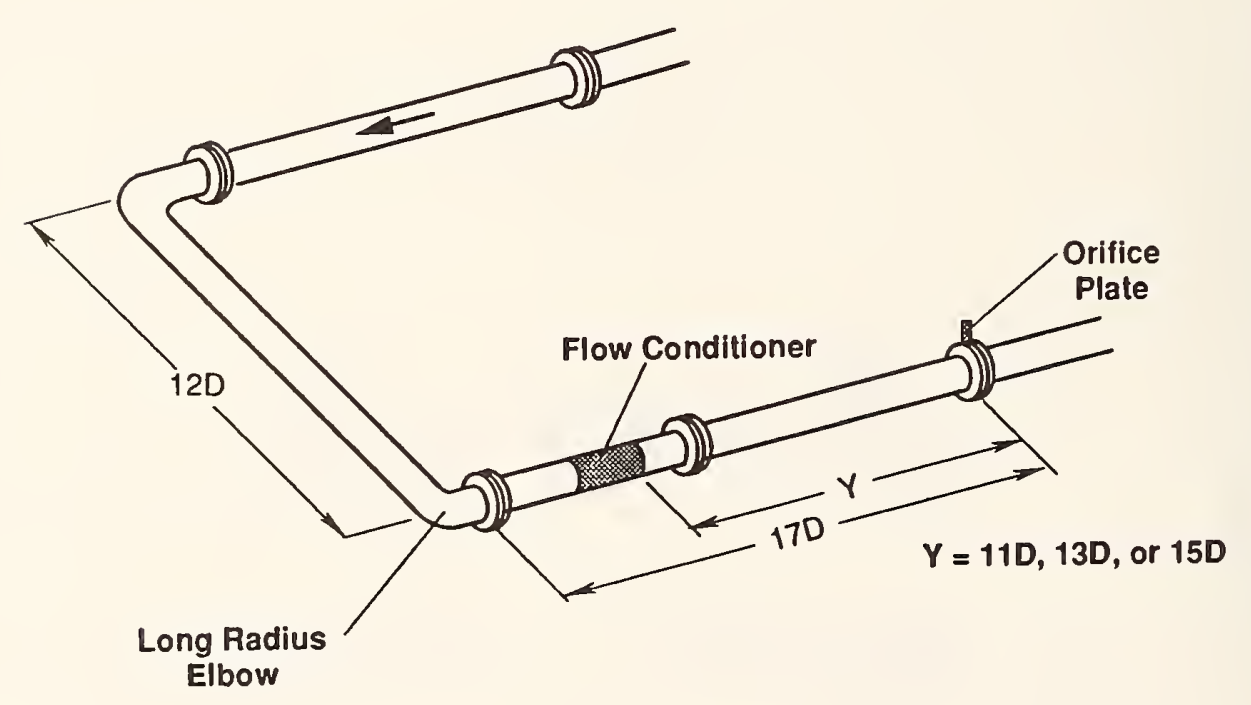

Figure 27. Test configuration, $104 \mathrm{~mm}$ (4in) orifice meter, elbow at 17D. 


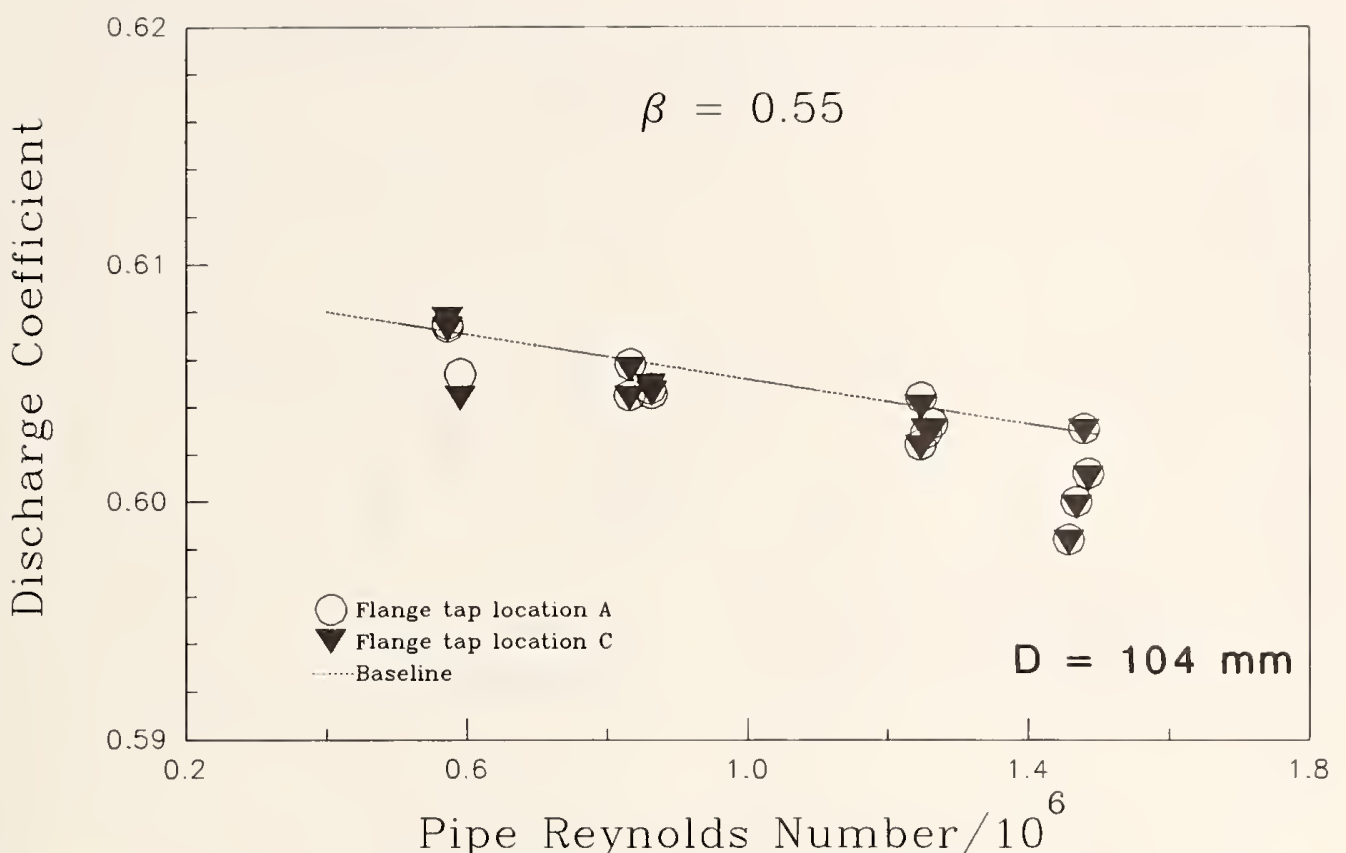

Figure 28. Discharge coefficient vs. Reynolds number for the 0.55 beta ratio plate with an elbow at $17 \mathrm{D}$, an in-line, 19 tube bundle at 13D, and 2 flange tap locations.

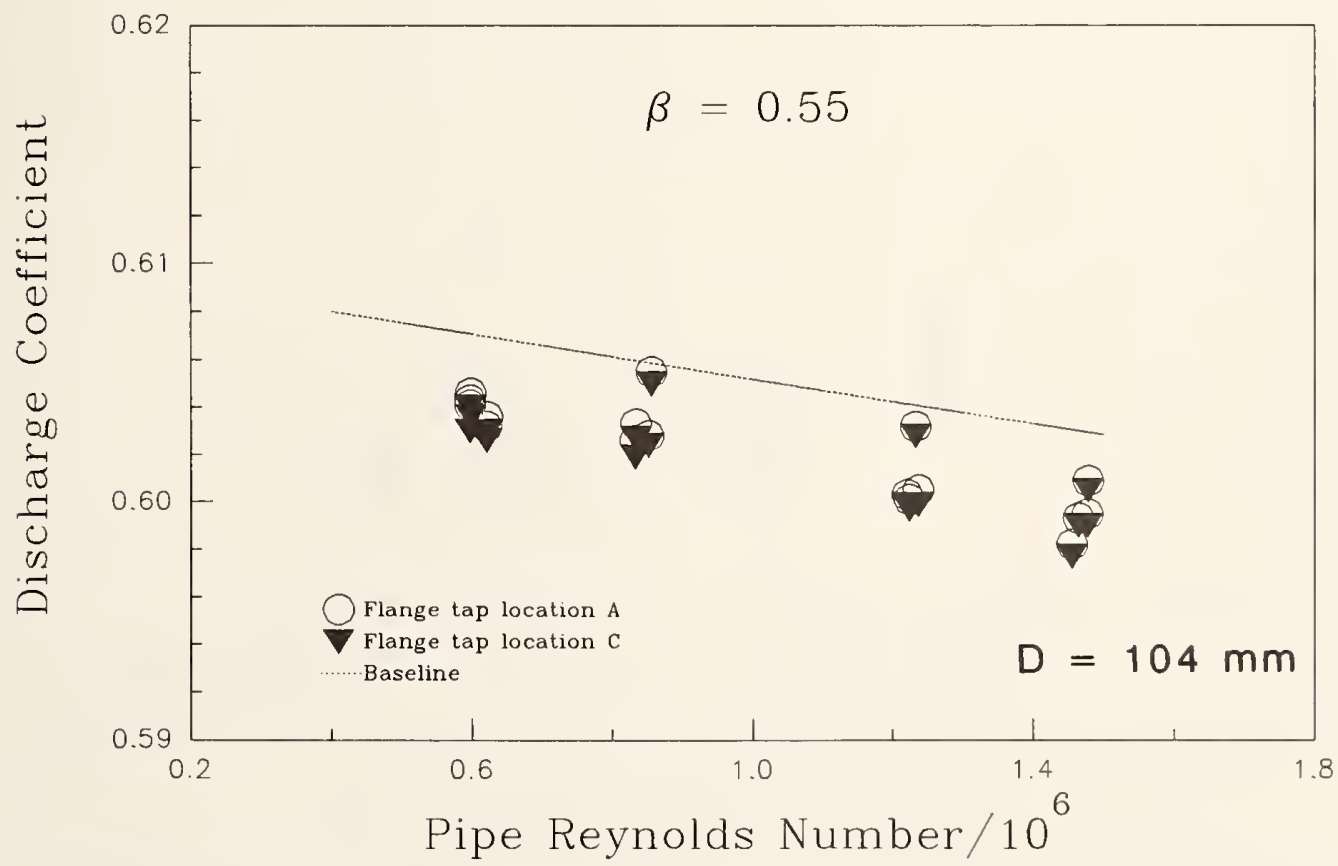

Figure 29. Discharge coefficient vs. Reynolds number for the 0.55 beta ratio plate with an elbow at $17 \mathrm{D}$, an in-line, 19 tube bundle at $11 \mathrm{D}$, and 2 flange tap locations. 


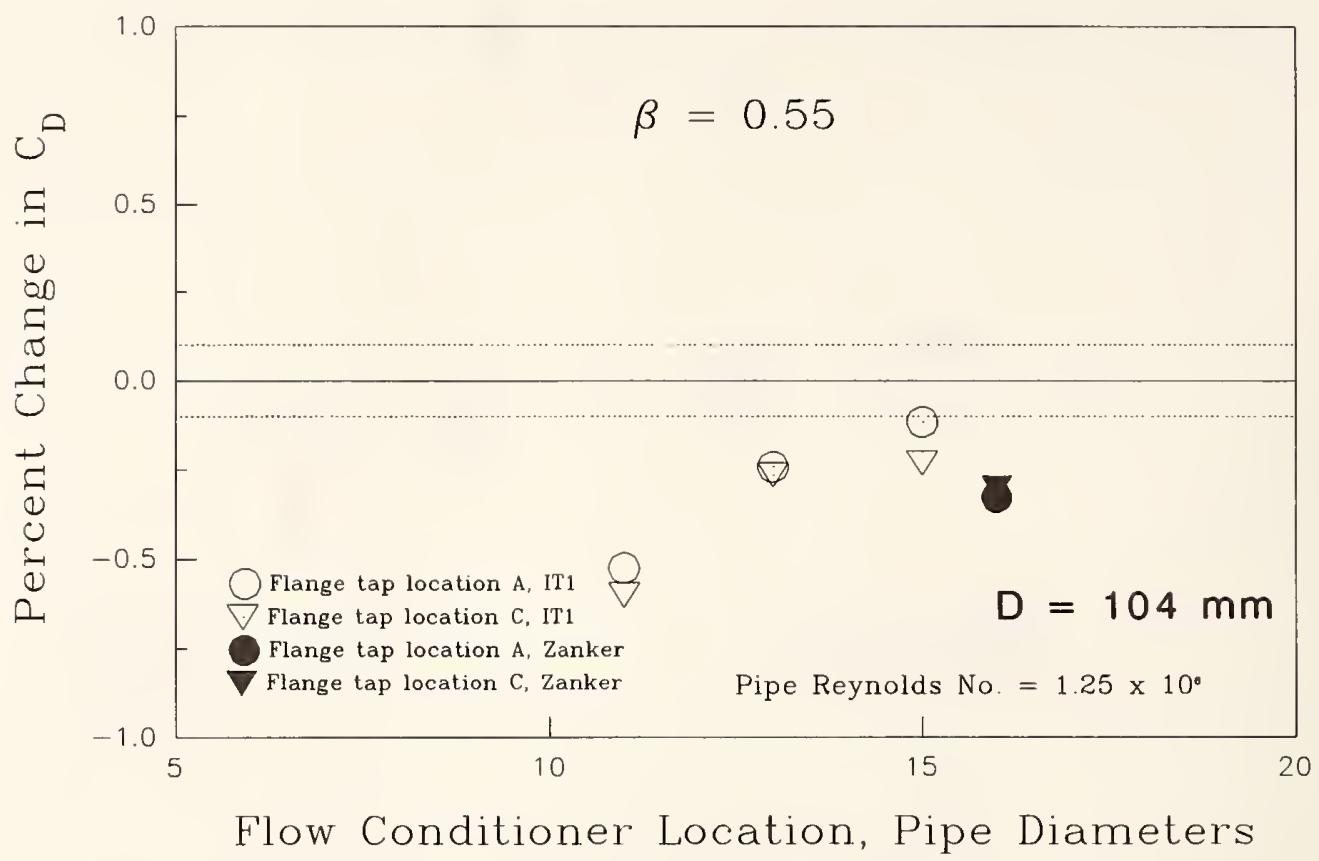

Figure 30. Percent change in discharge coefficient vs. flow conditioner location for the 0.55 beta ratio plate with an elbow at 17D and two flange tap locations.

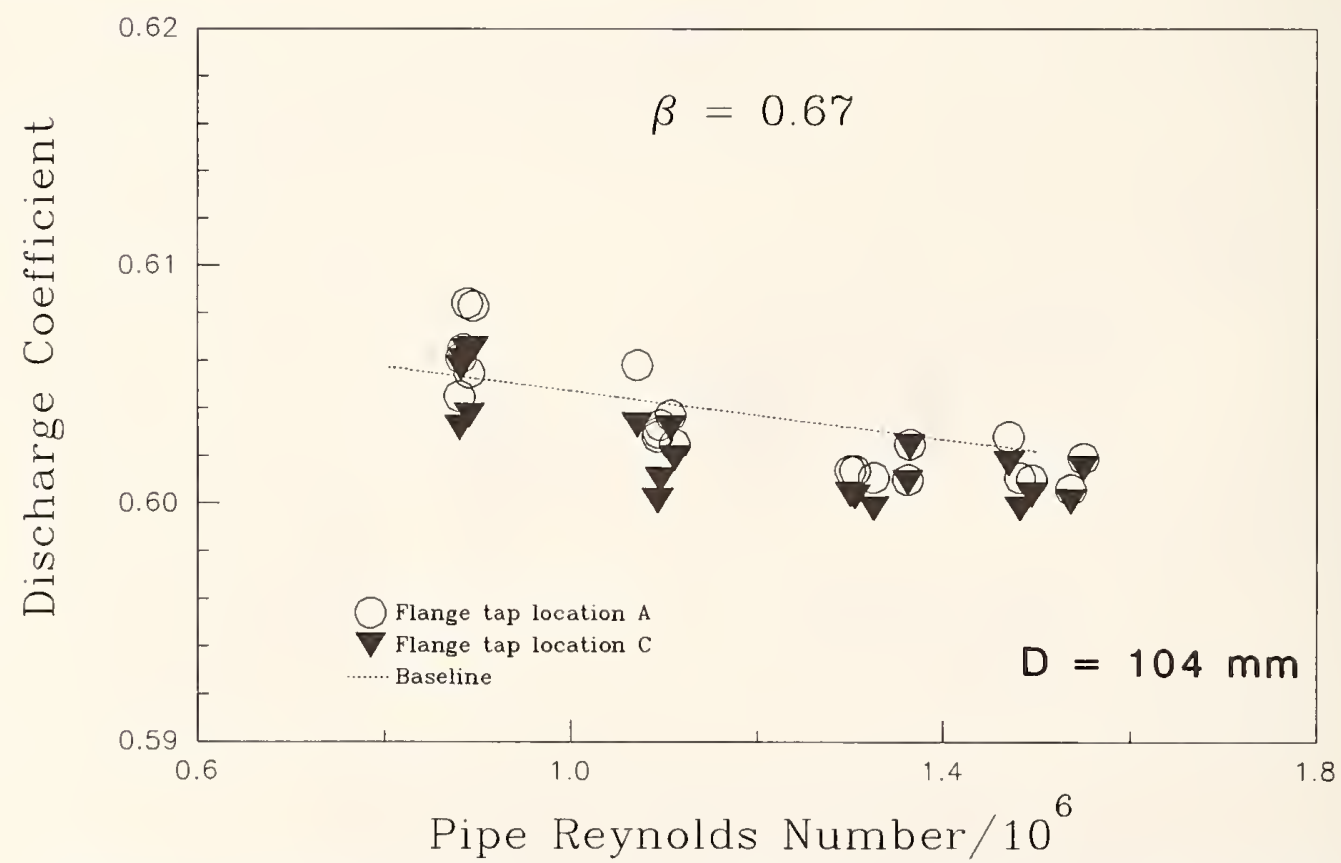

Figure 31. Discharge coefficient vs. Reynolds number for the 0.67 beta ratio plate with an elbow at $17 \mathrm{D}$, an in-line, 19 tube bundle at $13 \mathrm{D}$, and 2 flange tap locations. 


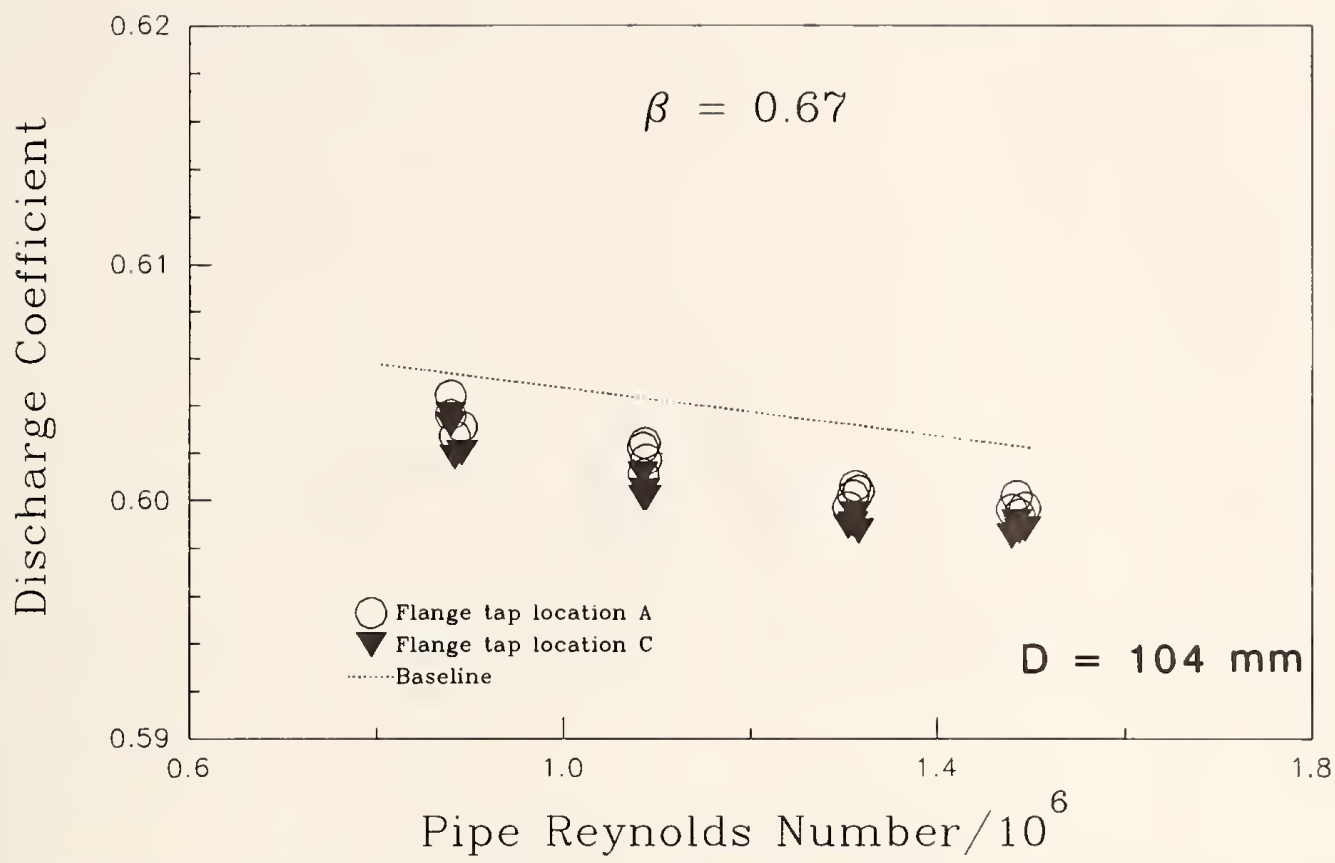

Figure 32. Discharge coefficient vs. Reynolds number for the 0.67 beta ratio plate with an elbow at $17 \mathrm{D}$, an in-line, 19 tube bundle at $11 \mathrm{D}$, and 2 flange tap locations.

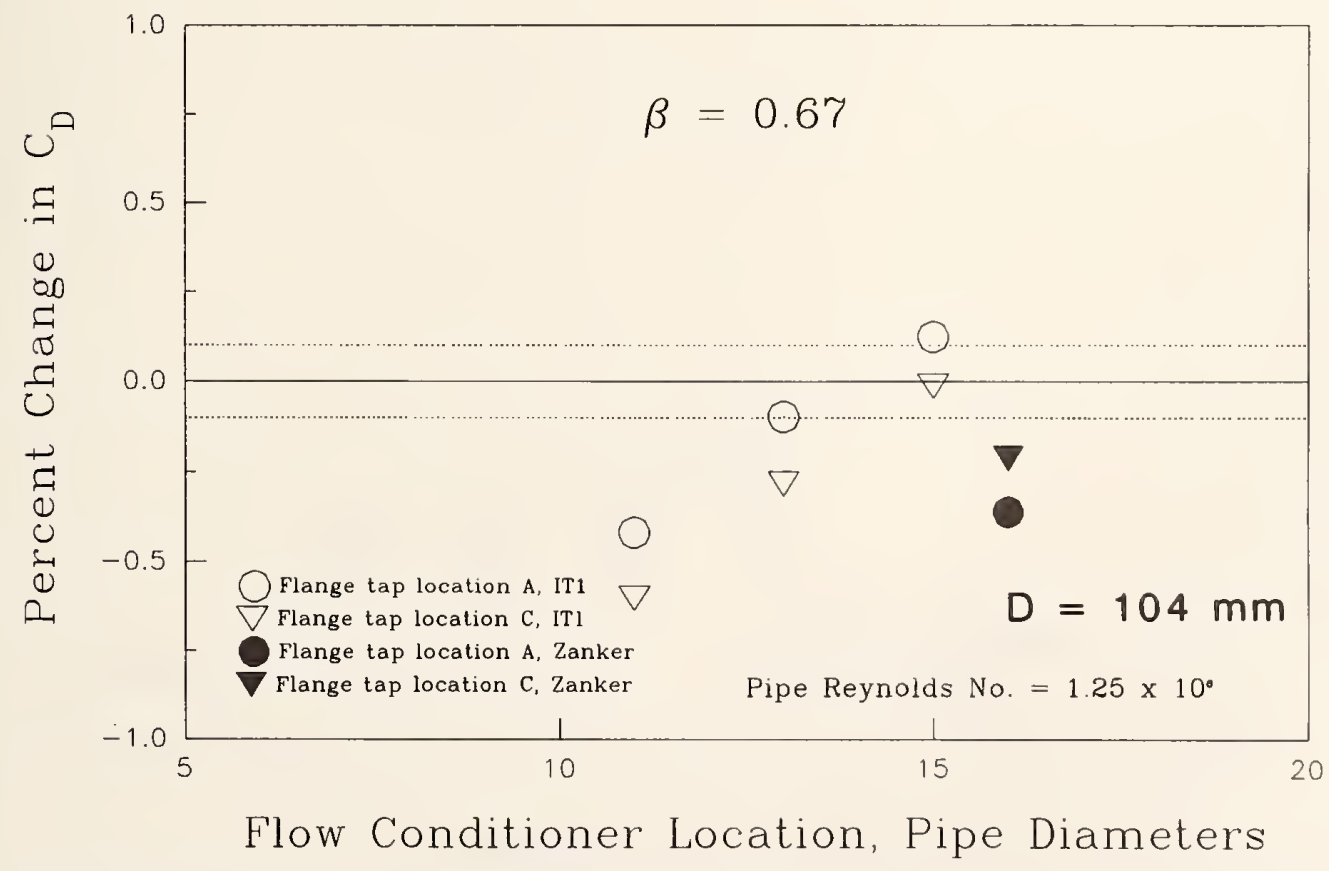

Figure 33. Percent change in discharge coefficient vs. flow conditioner location for the 0.67 beta ratio plate with an elbow at 17D and two flange tap locations 


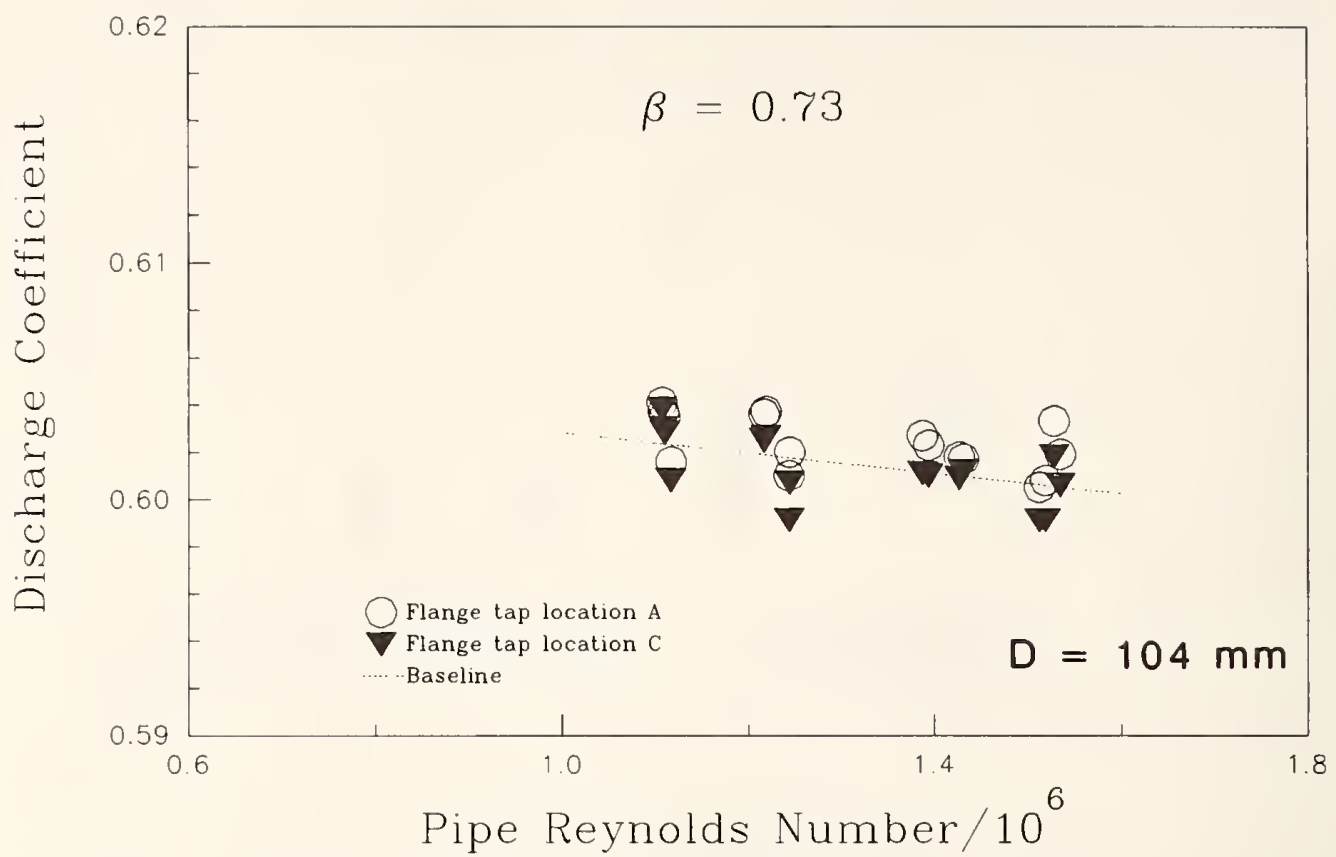

Figure 34. Discharge coefficient vs. Reynolds number for the 0.73 beta ratio plate with an elbow at 17D, an in-line, 19 tube bundle at $15 \mathrm{D}$, and 2 flange tap locations.

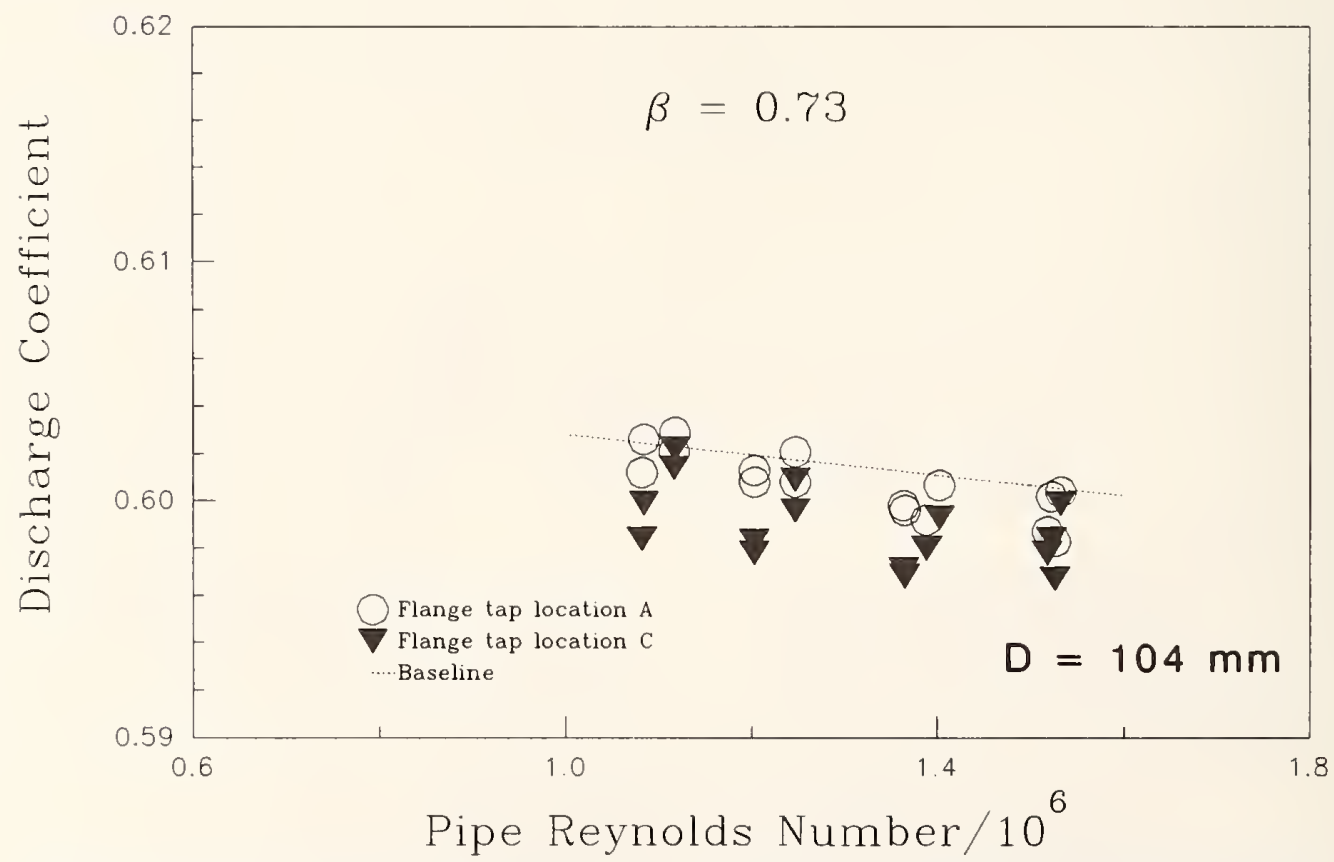

Figure 35. Discharge coefficient vs. Reynolds number for the 0.73 beta ratio plate with an elbow at $17 \mathrm{D}$, an in-line, 19 tube bundle at $13 \mathrm{D}$, and 2 flange tap locations. 


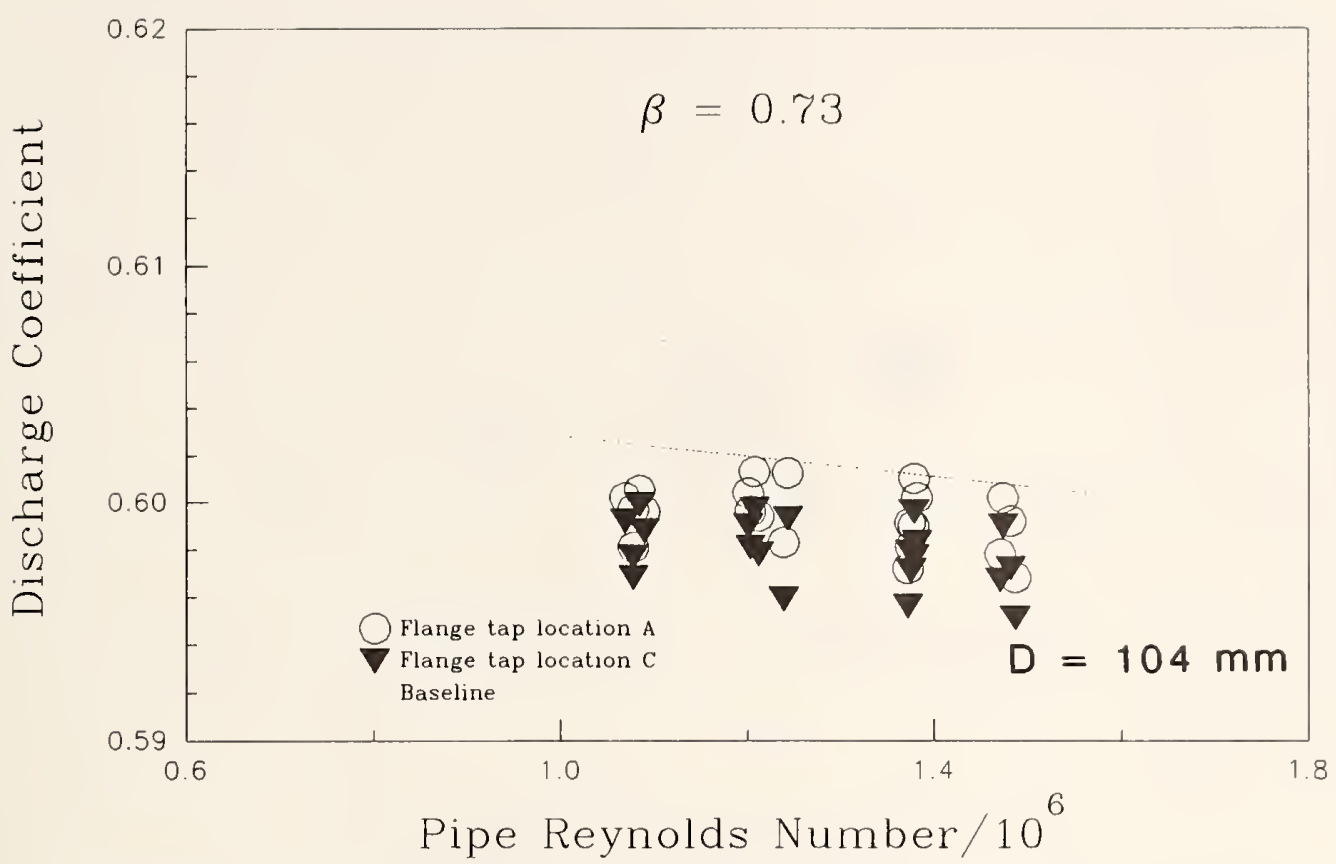

Figure 36. Discharge coefficient vs. Reynolds number for the 0.73 beta ratio plate with an elbow at $17 \mathrm{D}$, and in-line, 19 tube bundle at $11 \mathrm{D}$, and 2 flange tap locations

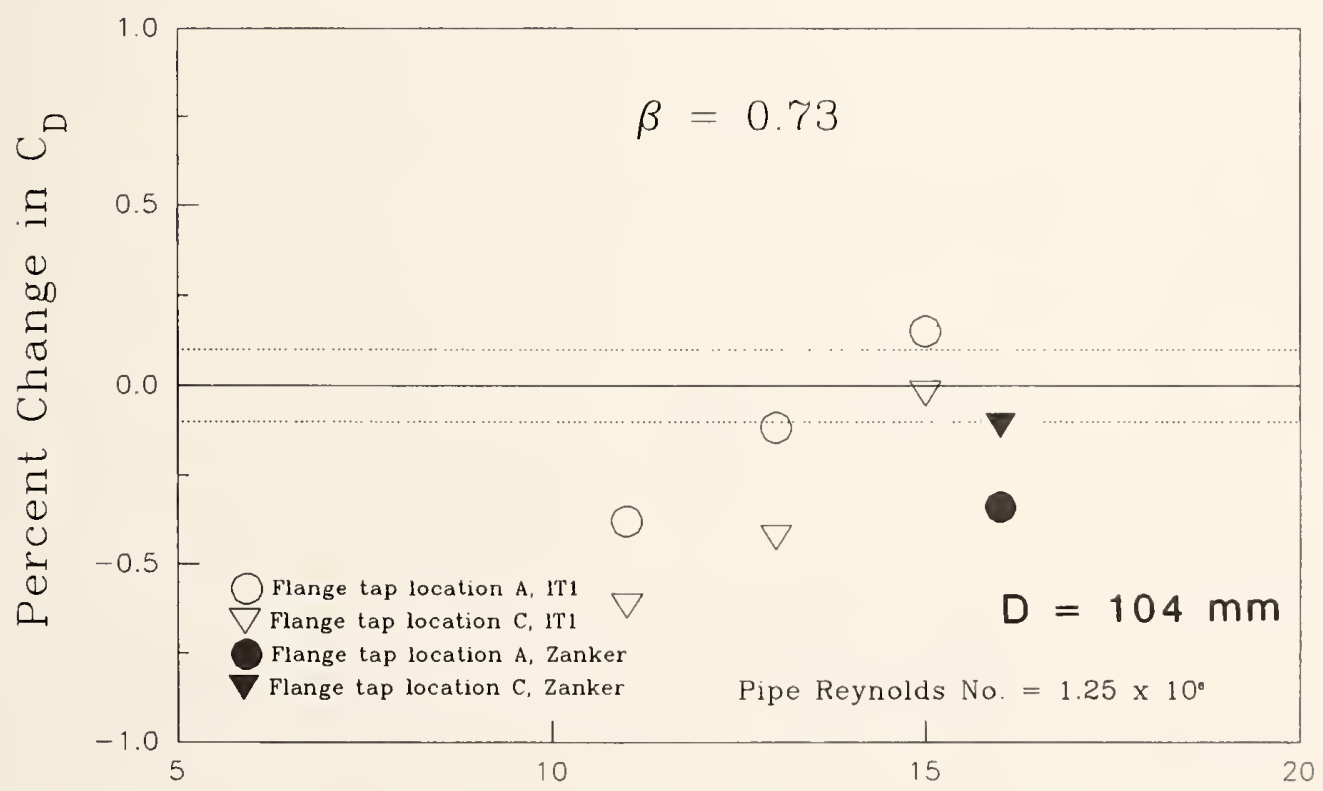

Flow Conditioner Location, Pipe Diameters

Figure 37. Percent change in discharge coefficient vs. flow conditioner location for the 0.73 beta ratio plate with an elbow at $17 \mathrm{D}$ and two flange tap locations. 


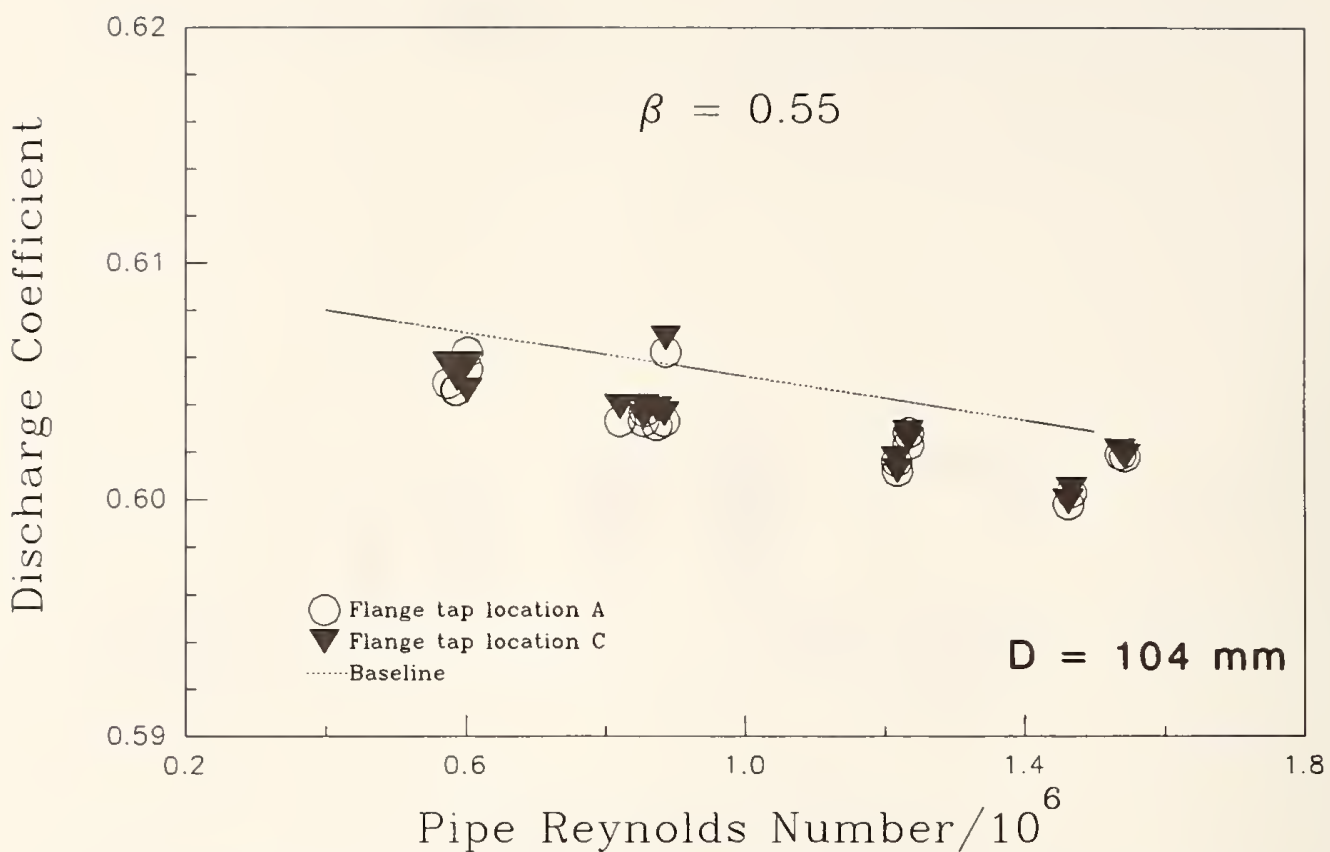

Figure 38. Discharge coefficient vs. Reynolds number for the 0.55 beta ratio plate with an elbow at $17 \mathrm{D}$, a Zanker at $16 \mathrm{D}$, and 2 flange tap locations.

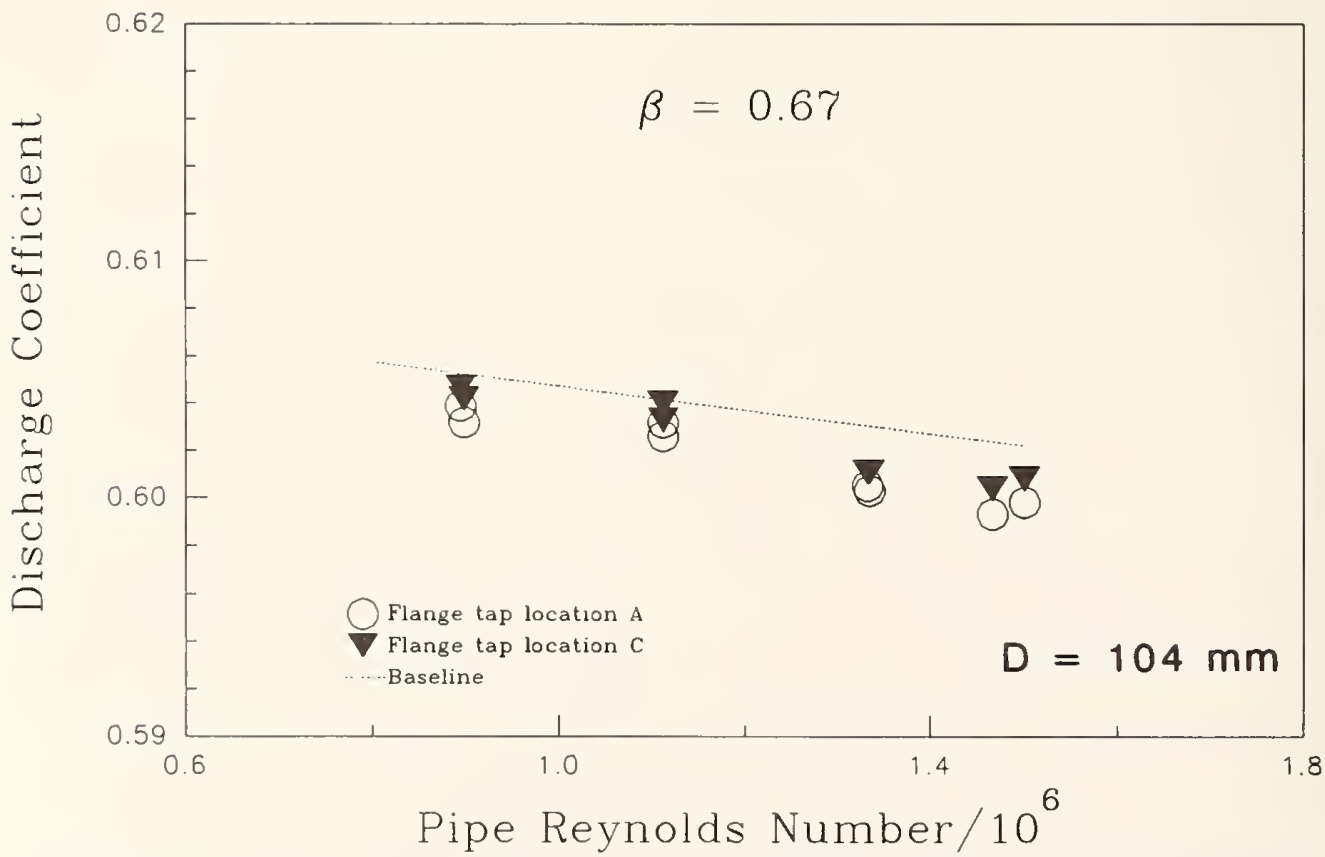

Figure 39. Discharge coefficient vs. Reynolds number for the 0.67 beta ratio plate with an elbow at 17D, a Zanker at 16D, and 2 flange tap locations. 


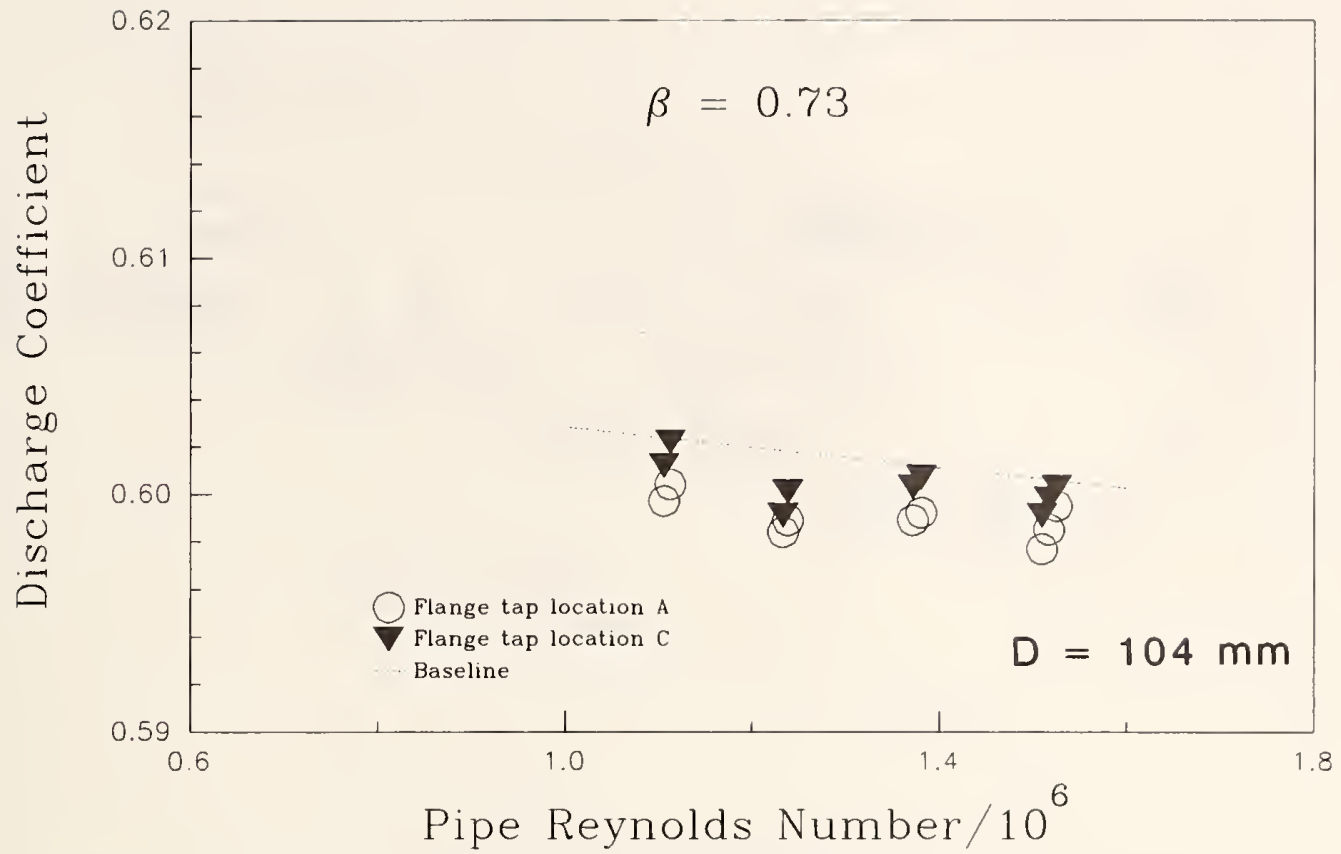

Figure 40. Discharge coefficient vs. Reynolds number for the 0.73 beta ratio plate with an elbow at $17 \mathrm{D}$, a Zanker at $16 \mathrm{D}$, and 2 flange tap locations. 


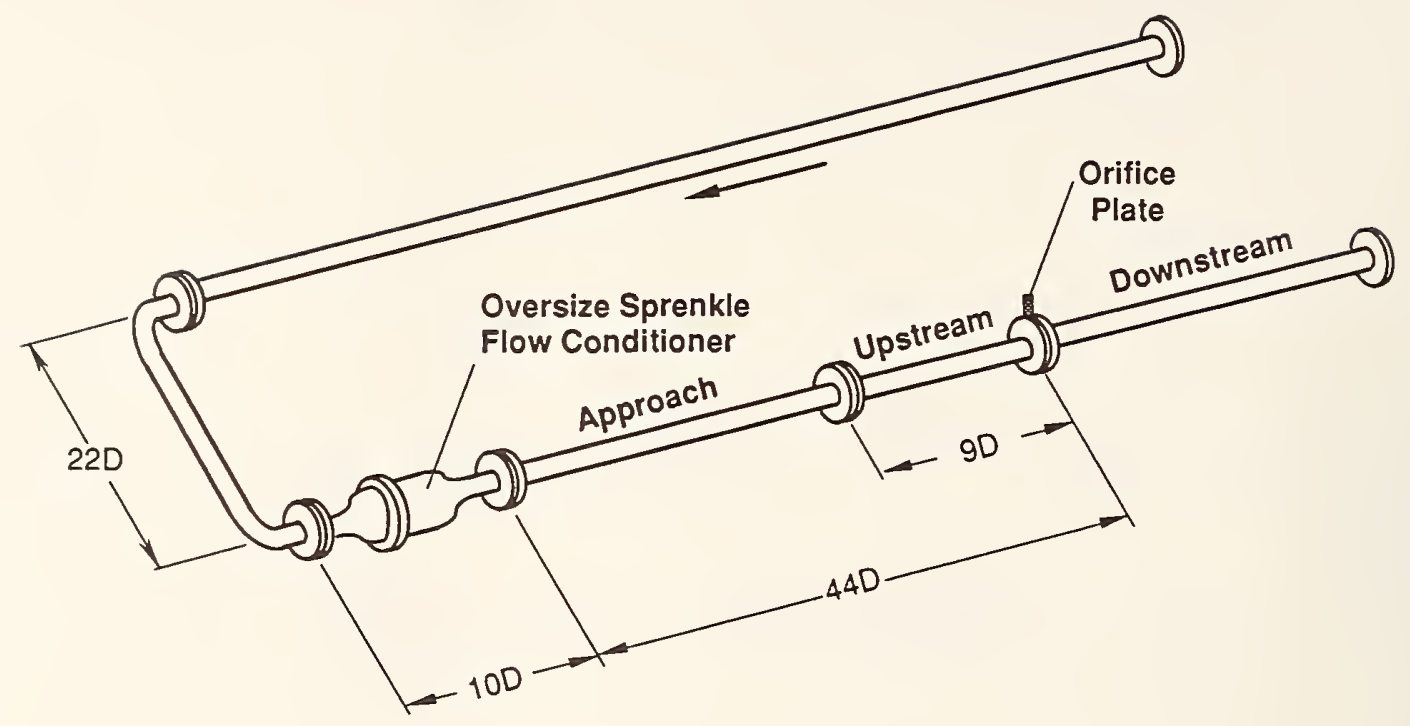

Figure 41. Baseline configuration, $52 \mathrm{~mm}$ ( 2 in) orifice meter, oversize Sprenkle at $44 \mathrm{D}$

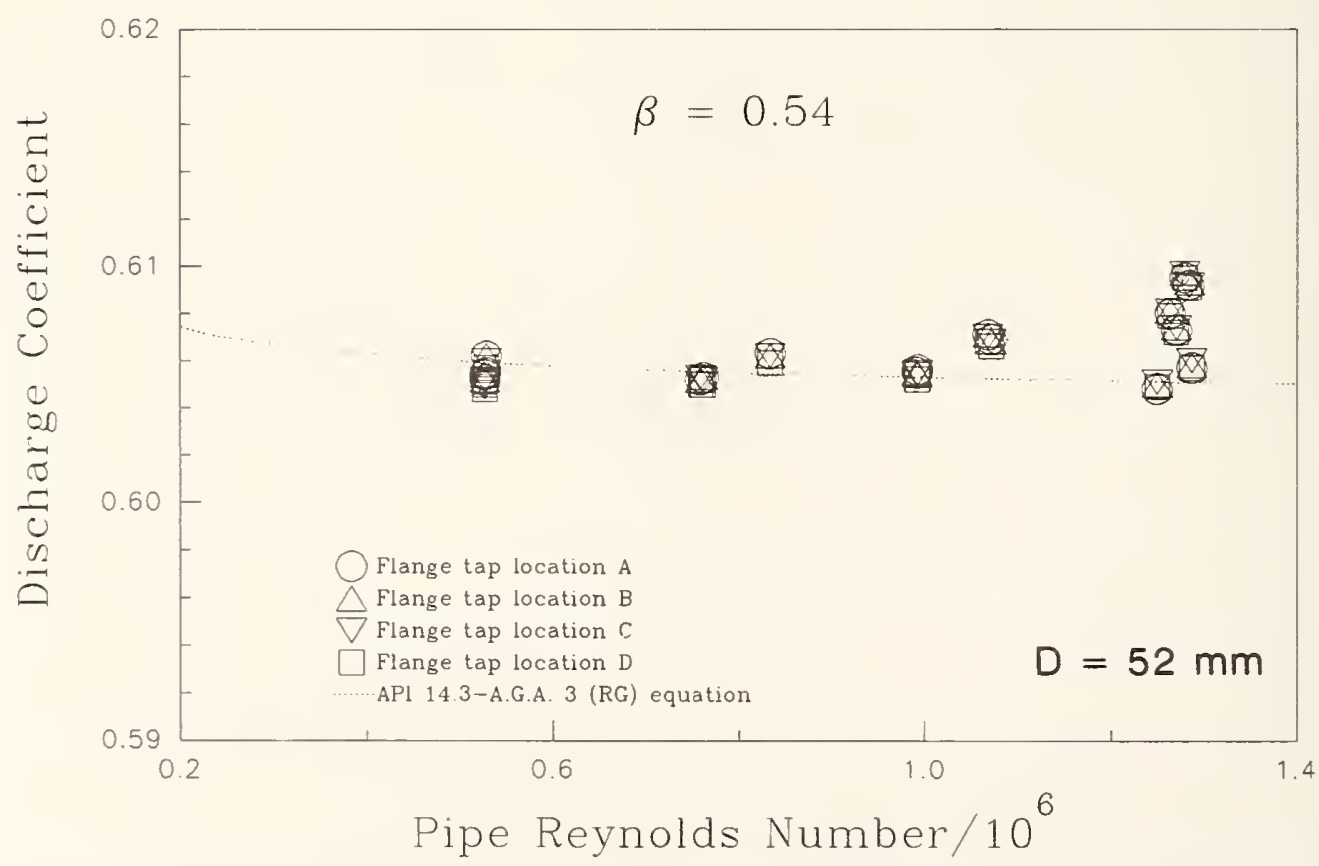

Figure 42. Discharge coefficient vs. Reynolds number for the 0.54 beta ratio plate, oversize Sprenkle at $44 \mathrm{D}$, and 4 flange tap locations. 


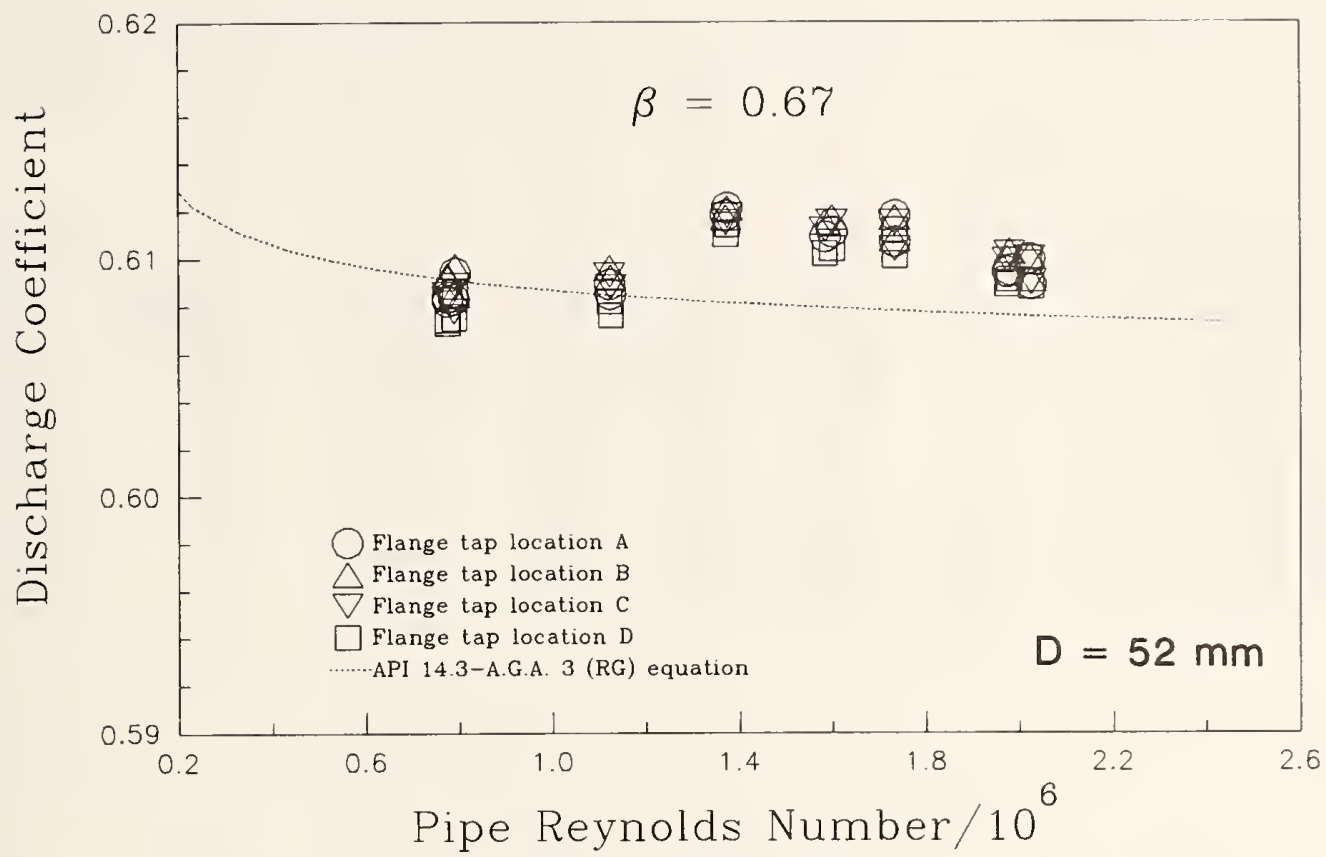

Figure 43. Discharge coefficient vs. Reynolds number for the 0.67 beta ratio plate, oversize Sprenkle at $44 \mathrm{D}$ and 4 flange tap locations.

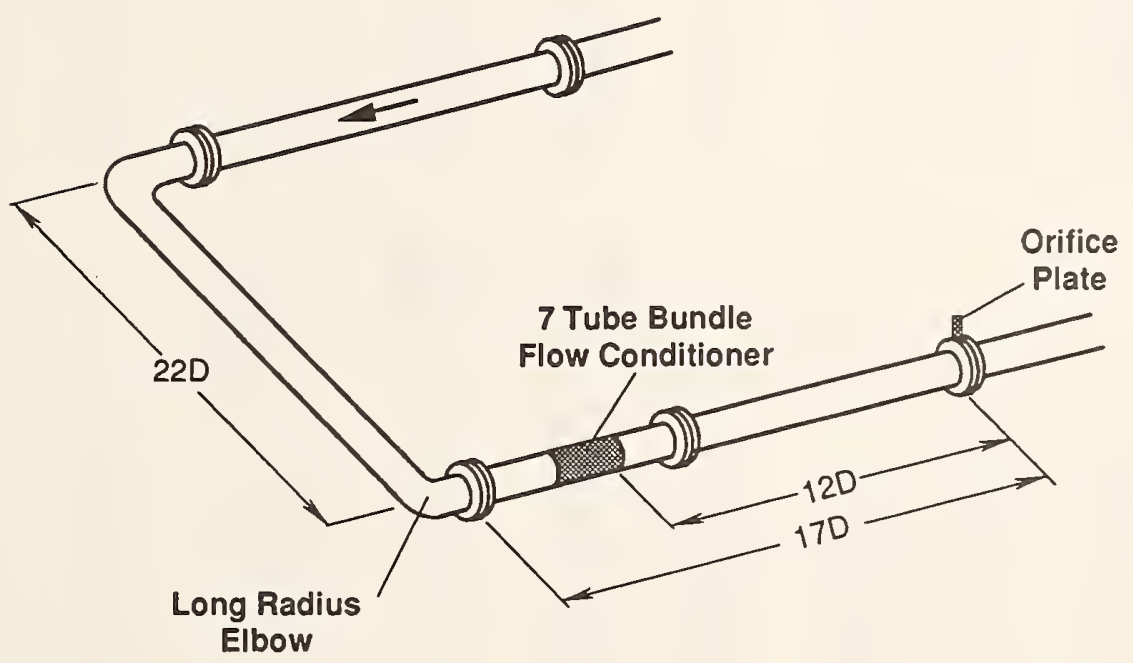

Figure 44. Test configuration, $52 \mathrm{~mm}$ ( 2 in) orifice meter, elbow at 17D. 


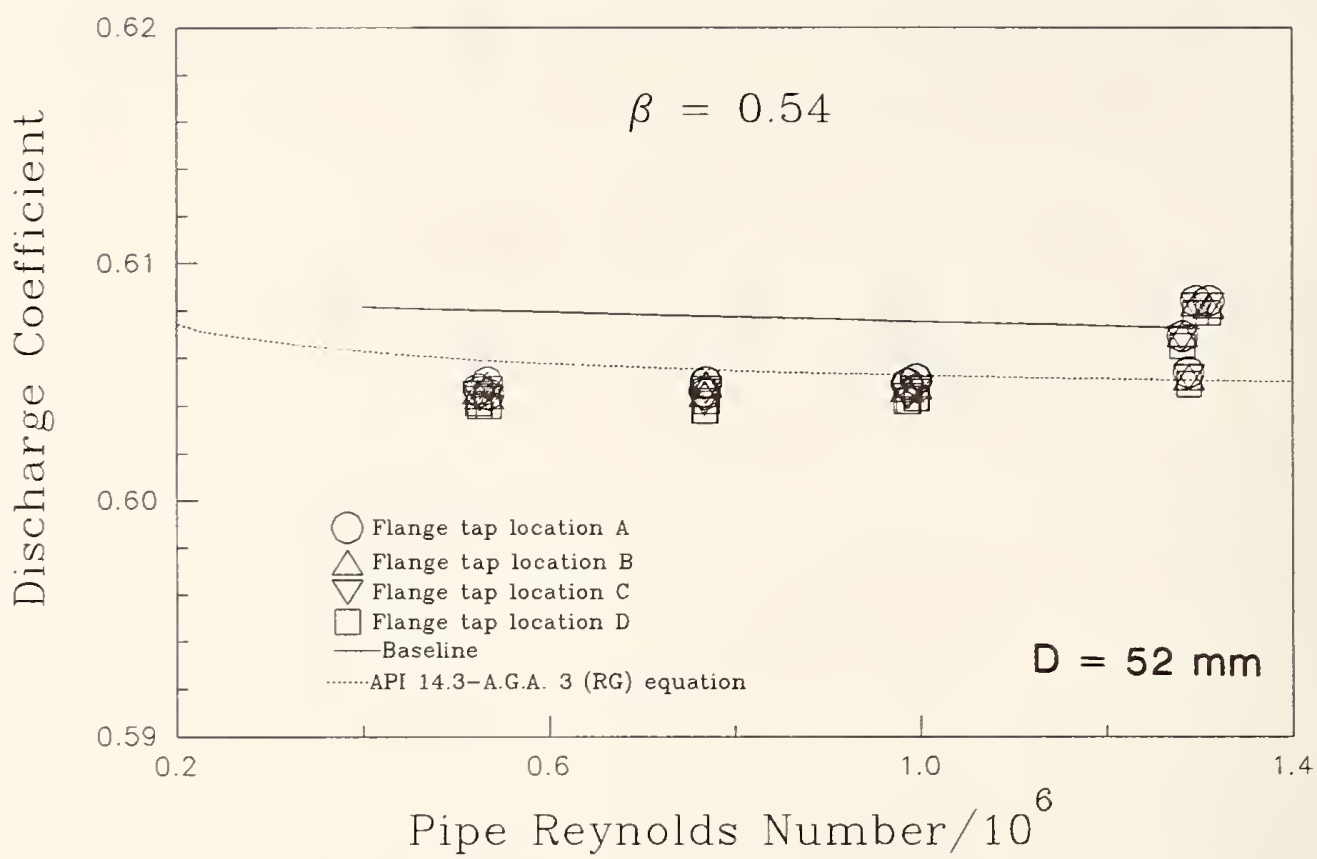

Figure 45. Discharge coefficient vs. Reynolds number for the 0.54 beta ratio plate, elbow at $17 \mathrm{D}$, and an in-line, 7 tube bundle at $12 \mathrm{D}$.

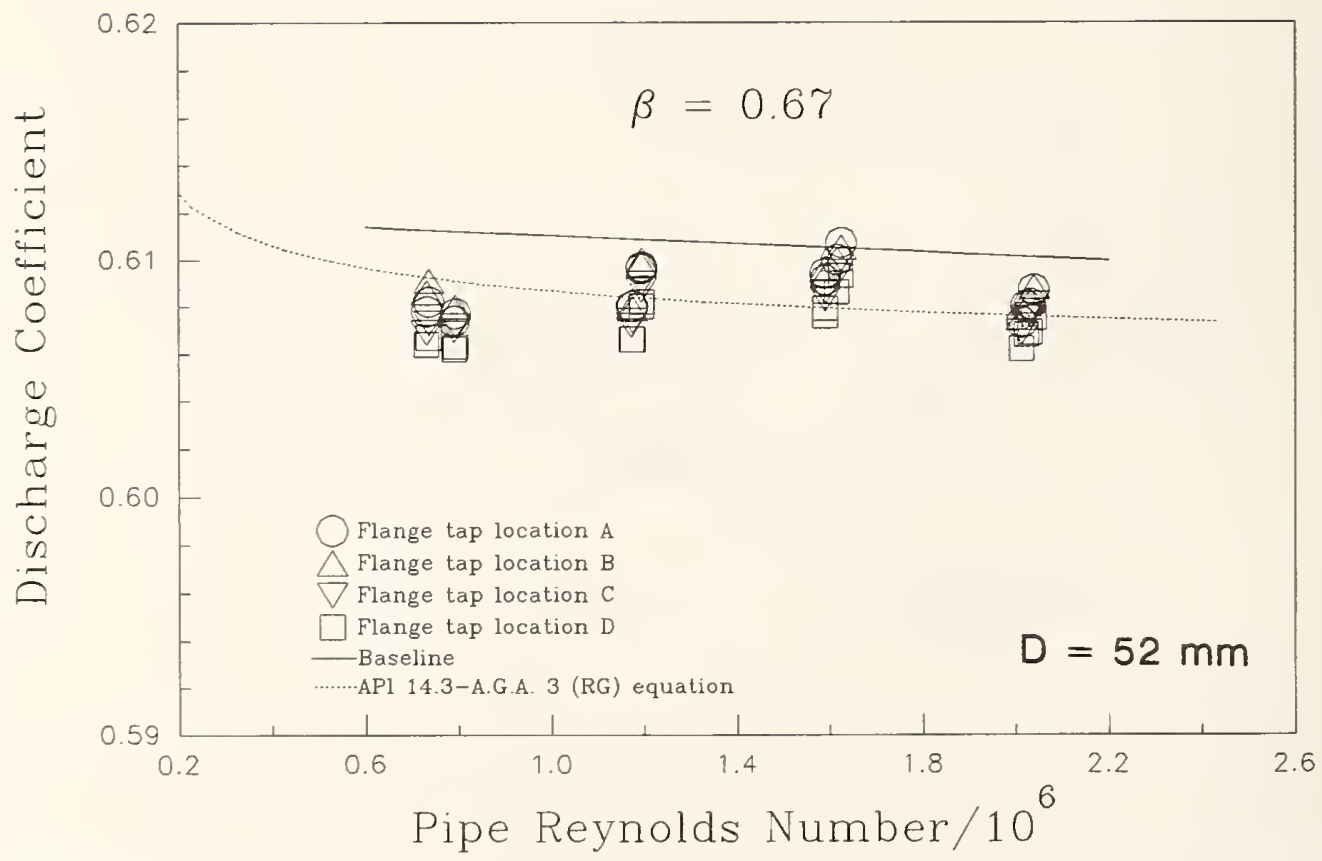

Figure 46. Discharge coefficient vs. Reynolds number for the 0.67 beta ratio plate, elbow at $17 \mathrm{D}$, and an in-line, 7 tube bundle at $12 \mathrm{D}$. 
Table 3. Measured and calculated quantities for 0.43 beta ratio, elbow at 1040 .

Pipe Dianeter $=10.366 \mathrm{~cm}(4.081 \mathrm{in}), 3.8 \mu \mathrm{m}$ Orifice Diameter $=4.4437 \mathrm{~cm}(1.7495 \mathrm{in})$

\begin{tabular}{|c|c|c|c|c|c|c|c|c|}
\hline Run ID & $\begin{array}{c}\text { Pressure } \\
\text { (MPa) }\end{array}$ & $\begin{array}{c}\text { Temperature } \\
\text { (X) }\end{array}$ & $\begin{array}{l}\text { Density } \\
\left(\mathrm{kg} / \mathrm{m}^{3}\right)\end{array}$ & $\begin{array}{l}\text { Dif Press } \\
\qquad(\mathrm{kPa})\end{array}$ & $\begin{array}{c}\text { Flow Rate } \\
(\mathrm{kg} / \mathrm{s})\end{array}$ & $\begin{array}{l}\text { Pipe Re No. } \\
\left(/ 10^{6}\right)\end{array}$ & C & $\mathrm{Cr}_{2}$ \\
\hline $\begin{array}{l}042491-1 \\
042491-2 \\
042491-3 \\
042491-4 \\
042491-5 \\
042491-6 \\
042491-7 \\
042491-8 \\
042591-1 \\
042591-2 \\
042591-3 \\
042591-4 \\
042591-5 \\
042591-6 \\
042591-7 \\
042591-8\end{array}$ & $\begin{array}{l}3.8308 \\
3.8430 \\
3.8836 \\
3.8884 \\
3.9692 \\
3.9556 \\
3.7495 \\
3.7766 \\
3.9556 \\
3.9590 \\
3.7812 \\
3.7879 \\
3.8842 \\
3.8831 \\
4.0201 \\
4.0176\end{array}$ & $\begin{array}{l}286.81 \\
286.72 \\
287.29 \\
287.09 \\
288.24 \\
288.11 \\
286.31 \\
285.91 \\
287.02 \\
286.86 \\
285.34 \\
286.14 \\
286.42 \\
286.22 \\
287.53 \\
287.69\end{array}$ & $\begin{array}{l}45.36 \\
45.52 \\
45.90 \\
45.99 \\
46.75 \\
46.61 \\
44.48 \\
44.87 \\
46.81 \\
46.87 \\
45.02 \\
44.97 \\
46.06 \\
46.09 \\
47.48 \\
47.42\end{array}$ & $\begin{array}{r}27.945 \\
27.930 \\
15.728 \\
15.740 \\
6.686 \\
6.762 \\
44.443 \\
44.401 \\
14.112 \\
13.971 \\
46.450 \\
45.680 \\
29.642 \\
29.948 \\
6.903 \\
7.175\end{array}$ & $\begin{array}{l}1.5059 \\
1.5090 \\
1.1404 \\
1.1426 \\
0.7512 \\
0.7556 \\
1.8807 \\
1.8900 \\
1.0916 \\
1.0880 \\
1.9450 \\
1.9245 \\
1.5693 \\
1.5754 \\
0.7698 \\
0.7846\end{array}$ & $\begin{array}{l}1.0250 \\
1.0272 \\
0.7749 \\
0.7766 \\
0.5087 \\
0.5119 \\
1.2829 \\
1.2901 \\
0.7415 \\
0.7393 \\
1.3294 \\
1.3128 \\
1.0685 \\
1.0731 \\
0.5219 \\
0.5317\end{array}$ & $\begin{array}{l}0.5986 \\
0.5990 \\
0.6011 \\
0.6014 \\
0.6022 \\
0.6032 \\
0.5981 \\
0.5987 \\
0.6016 \\
0.6022 \\
0.6013 \\
0.6004 \\
0.6010 \\
0.6001 \\
0.6027 \\
0.6029\end{array}$ & $\begin{array}{l}0.5996 \\
0.5999 \\
0.6017 \\
0.6020 \\
0.6025 \\
0.6035 \\
0.5996 \\
0.6003 \\
0.6021 \\
0.6027 \\
0.6029 \\
0.6020 \\
0.6020 \\
0.6011 \\
0.6029 \\
0.6031\end{array}$ \\
\hline
\end{tabular}

Table 4. Measured and calculated quantities for 0.55 beta ratio, elbow at 1040.

Pipe Diameter $=10.366 \mathrm{~cm}(4.081 \mathrm{in}), 3.8 \mu \mathrm{m}$ Orifice Diameter $=5.7142 \mathrm{~cm}(2.2497 \mathrm{in})$

\begin{tabular}{|c|c|c|c|c|c|c|c|c|}
\hline Run ID & $\begin{array}{c}\text { Pressure } \\
\text { (MPa) }\end{array}$ & $\begin{array}{c}\text { Temperature } \\
\text { (K) }\end{array}$ & $\begin{array}{l}\text { Density } \\
\left(\mathrm{kg} / \mathrm{m}^{3}\right)\end{array}$ & $\begin{array}{c}\text { Dif Press } \\
\text { (kPa) }\end{array}$ & $\begin{array}{c}\text { Flow Rate } \\
(\mathrm{kg} / \mathrm{s})\end{array}$ & $\begin{array}{c}\text { Pipe Re No. } \\
\left(/ 10^{6}\right)\end{array}$ & C & $\mathrm{Cr}_{2}$ \\
\hline $\begin{array}{l}042391-1 \\
042391-2 \\
042391-3 \\
042391-4 \\
042391-5 \\
042391-6 \\
042391-7 \\
042391-8 \\
042391-9 \\
042391-10 \\
042591-1 \\
042591-2 \\
042591-3 \\
042591-4 \\
042591-5 \\
042591-6 \\
042591-7 \\
042591-8\end{array}$ & $\begin{array}{l}3.8773 \\
3.8710 \\
3.9454 \\
3.9493 \\
3.7199 \\
3.7162 \\
4.0292 \\
4.0275 \\
3.8571 \\
3.8518 \\
3.9493 \\
3.9435 \\
3.7345 \\
3.7255 \\
3.8423 \\
3.8345 \\
3.9968 \\
3.9968\end{array}$ & $\begin{array}{l}286.73 \\
286.49 \\
287.19 \\
287.08 \\
278.90 \\
275.50 \\
287.21 \\
287.45 \\
286.32 \\
286.26 \\
286.70 \\
286.66 \\
285.01 \\
284.77 \\
286.29 \\
285.90 \\
287.13 \\
287.30\end{array}$ & $\begin{array}{l}45.93 \\
45.89 \\
46.65 \\
46.72 \\
45.43 \\
46.00 \\
47.65 \\
47.58 \\
45.76 \\
45.71 \\
46.79 \\
46.73 \\
44.52 \\
44.46 \\
45.59 \\
45.56 \\
47.28 \\
47.24\end{array}$ & $\begin{array}{r}12.827 \\
12.779 \\
6.198 \\
6.255 \\
20.542 \\
20.203 \\
2.504 \\
2.938 \\
12.579 \\
12.347 \\
6.219 \\
6.174 \\
19.645 \\
19.771 \\
13.645 \\
13.214 \\
3.049 \\
3.037\end{array}$ & $\begin{array}{l}1.7571 \\
1.7548 \\
1.2371 \\
1.2433 \\
2.2192 \\
2.2108 \\
0.7973 \\
0.8635 \\
1.7421 \\
1.7267 \\
1.2456 \\
1.2383 \\
2.1377 \\
2.1485 \\
1.8085 \\
1.7827 \\
0.8744 \\
0.8737\end{array}$ & $\begin{array}{l}1.1956 \\
1.1947 \\
0.8401 \\
0.8445 \\
1.5424 \\
1.5498 \\
0.5409 \\
0.5855 \\
1.1868 \\
1.1765 \\
0.8469 \\
0.8420 \\
1.4631 \\
1.4715 \\
1.2324 \\
1.2161 \\
0.5935 \\
0.5928\end{array}$ & $\begin{array}{l}0.6011 \\
0.6016 \\
0.6042 \\
0.6041 \\
0.6031 \\
0.6021 \\
0.6066 \\
0.6068 \\
0.6029 \\
0.6035 \\
0.6065 \\
0.6056 \\
0.6000 \\
0.6015 \\
0.6021 \\
0.6032 \\
0.6051 \\
0.6061\end{array}$ & $\begin{array}{l}0.6015 \\
0.6020 \\
0.6044 \\
0.6043 \\
0.6038 \\
0.6028 \\
0.6066 \\
0.6069 \\
0.6033 \\
0.6039 \\
0.6067 \\
0.6058 \\
0.6006 \\
0.6022 \\
0.6025 \\
0.6037 \\
0.6052 \\
0.6062\end{array}$ \\
\hline
\end{tabular}

Table 5. Measured and calculated quantities for 0.67 beta ratio, elbow at 1040 .

Pipe Diameter $=10.366 \mathrm{~cm}(4.081 \mathrm{in}), 3.8 \mu \mathrm{m}$ Orifice Dianeter $=6.9840 \mathrm{~cm}(2.7496 \mathrm{in})$

\begin{tabular}{|c|c|c|c|c|c|c|c|c|}
\hline Run 10 & $\begin{array}{c}\text { Pressure } \\
\text { (MPa) }\end{array}$ & $\begin{array}{c}\text { Temperature } \\
\text { (K) }\end{array}$ & $\begin{array}{l}\text { Oensity } \\
\left(\mathrm{kg} / \mathrm{m}^{3}\right)\end{array}$ & $\begin{array}{l}\text { Dif Press } \\
\text { (KPa) }\end{array}$ & $\begin{array}{c}\text { Flow Rate } \\
(\mathrm{kg} / \mathrm{s})\end{array}$ & $\begin{array}{l}\text { Pipe Re No. } \\
\left(/ 10^{6}\right)\end{array}$ & C & $\mathrm{CY}_{2}$ \\
\hline $\begin{array}{l}042391-1 \\
042391-2 \\
042391-3 \\
042391-4 \\
042391-5 \\
042391-6 \\
042391-7 \\
042391-8 \\
042391-9 \\
042391-10 \\
042591-1 \\
042591-2 \\
042591-3 \\
042591-4 \\
042591-5 \\
042591-6 \\
042591-7 \\
042591-8\end{array}$ & $\begin{array}{l}3.8924 \\
3.8873 \\
3.8869 \\
3.8078 \\
3.7981 \\
3.7172 \\
3.7350 \\
3.9161 \\
3.9181 \\
3.7907 \\
3.8605 \\
3.8597 \\
3.9789 \\
3.9743 \\
3.7585 \\
3.7667 \\
3.9202 \\
3.9139\end{array}$ & $\begin{array}{l}286.81 \\
286.38 \\
286.46 \\
285.99 \\
286.48 \\
285.06 \\
285.52 \\
286.72 \\
286.82 \\
286.00 \\
285.93 \\
285.91 \\
286.87 \\
287.16 \\
285.51 \\
285.45 \\
286.32 \\
286.43\end{array}$ & $\begin{array}{l}46.09 \\
46.11 \\
46.09 \\
45.23 \\
45.03 \\
44.31 \\
44.44 \\
46.39 \\
46.40 \\
45.02 \\
45.87 \\
45.86 \\
47.11 \\
47.00 \\
44.72 \\
44.83 \\
46.51 \\
46.42\end{array}$ & $\begin{array}{l}3.887 \\
3.873 \\
3.876 \\
5.783 \\
5.787 \\
7.805 \\
7.357 \\
2.574 \\
2.595 \\
5.824 \\
5.811 \\
5.797 \\
2.581 \\
2.595 \\
8.068 \\
7.603 \\
3.759 \\
3.821\end{array}$ & $\begin{array}{l}1.5598 \\
1.5505 \\
1.5550 \\
1.8695 \\
1.8731 \\
2.1609 \\
2.1029 \\
1.2735 \\
1.2789 \\
1.8830 \\
1.8924 \\
1.8929 \\
1.2863 \\
1.2872 \\
2.2056 \\
2.1418 \\
1.5358 \\
1.5470\end{array}$ & $\begin{array}{l}1.0609 \\
1.0557 \\
1.0586 \\
1.2754 \\
1.2765 \\
1.4792 \\
1.4375 \\
0.8661 \\
0.8696 \\
1.2848 \\
1.2904 \\
1.2908 \\
0.8738 \\
0.8739 \\
1.5074 \\
1.4638 \\
1.0455 \\
1.0529\end{array}$ & $\begin{array}{l}0.6061 \\
0.6035 \\
0.6051 \\
0.6012 \\
0.6035 \\
0.6043 \\
0.6048 \\
0.6062 \\
0.6062 \\
0.6047 \\
0.6028 \\
0.6038 \\
0.6068 \\
0.6063 \\
0.6038 \\
0.6033 \\
0.6042 \\
0.6042\end{array}$ & $\begin{array}{l}0.6062 \\
0.6036 \\
0.6052 \\
0.6014 \\
0.6037 \\
0.6045 \\
0.6050 \\
0.6062 \\
0.6063 \\
0.6049 \\
0.6030 \\
0.6039 \\
0.6068 \\
0.6063 \\
0.6041 \\
0.6035 \\
0.6043 \\
0.6043\end{array}$ \\
\hline
\end{tabular}


Table 6. Measured and calculated quantities for 0.73 beta ratio, elbow at 1040 .

Pipe Diameter $=10.366 \mathrm{~cm}(4.081 \mathrm{in}), 3.8 \mu \mathrm{m}$ Orifice Diameter $=7.6197 \mathrm{~cm}(2.9999 \mathrm{in})$

\begin{tabular}{|c|c|c|c|c|c|c|c|c|}
\hline Run ID & $\begin{array}{c}\text { Pressure } \\
\text { (MPa) }\end{array}$ & $\begin{array}{c}\text { Temperature } \\
\text { (K) }\end{array}$ & $\begin{array}{l}\text { Density } \\
\left(\mathrm{kg} / \mathrm{m}^{3}\right)\end{array}$ & $\begin{array}{l}\text { Dif Press } \\
\text { (KPa) }\end{array}$ & $\begin{array}{c}\text { Flow Rate } \\
(\mathrm{kg} / \mathrm{s})\end{array}$ & $\begin{array}{l}\text { Pipe Re No. } \\
\left(/ 10^{6}\right)\end{array}$ & C & $\mathrm{CY}_{2}$ \\
\hline $\begin{array}{l}042291-4 \\
042291-5 \\
042291-6 \\
042291-7 \\
042291-8 \\
042291-1 \\
042291-2 \\
042491-1 \\
042491-2 \\
042491-3 \\
042491-4 \\
042491-5 \\
042491-6 \\
042491-7 \\
042491-8 \\
042491-9 \\
042491-10\end{array}$ & $\begin{array}{l}3.8179 \\
3.8665 \\
3.8592 \\
3.7767 \\
3.7217 \\
3.8423 \\
3.8453 \\
3.8415 \\
3.8432 \\
3.7154 \\
3.7132 \\
3.8599 \\
3.8620 \\
3.7721 \\
3.7709 \\
3.8144 \\
3.8042\end{array}$ & $\begin{array}{l}285.93 \\
286.56 \\
285.94 \\
285.53 \\
285.29 \\
286.28 \\
286.21 \\
286.00 \\
286.35 \\
285.26 \\
278.61 \\
286.28 \\
285.67 \\
286.27 \\
285.04 \\
286.03 \\
285.86\end{array}$ & $\begin{array}{l}45.36 \\
45.83 \\
45.85 \\
44.94 \\
44.32 \\
45.59 \\
45.64 \\
45.63 \\
45.59 \\
44.25 \\
45.39 \\
45.80 \\
45.93 \\
44.75 \\
44.95 \\
45.30 \\
45.21\end{array}$ & $\begin{array}{l}4.159 \\
3.258 \\
3.282 \\
4.935 \\
5.073 \\
3.148 \\
3.152 \\
3.204 \\
3.208 \\
5.095 \\
4.940 \\
2.732 \\
2.740 \\
4.168 \\
4.109 \\
3.548 \\
3.556\end{array}$ & $\begin{array}{l}2.0077 \\
1.7850 \\
1.7936 \\
2.1751 \\
2.1850 \\
1.7527 \\
1.7509 \\
1.7747 \\
1.7722 \\
2.1974 \\
2.1892 \\
1.6361 \\
1.6421 \\
1.9951 \\
1.9864 \\
1.8519 \\
1.8514\end{array}$ & $\begin{array}{l}1.3697 \\
1.2152 \\
1.2230 \\
1.4861 \\
1.4947 \\
1.1944 \\
1.1933 \\
1.2102 \\
1.2074 \\
1.5034 \\
1.5228 \\
1.1146 \\
1.1204 \\
1.3607 \\
1.3589 \\
1.2631 \\
1.2635\end{array}$ & $\begin{array}{l}0.6032 \\
0.6028 \\
0.6033 \\
0.6027 \\
0.6013 \\
0.6037 \\
0.6024 \\
0.6057 \\
0.6048 \\
0.6039 \\
0.6034 \\
0.6036 \\
0.6040 \\
0.6028 \\
0.6031 \\
0.6027 \\
0.6026\end{array}$ & $\begin{array}{l}0.6033 \\
0.6029 \\
0.6034 \\
0.6028 \\
0.6014 \\
0.6038 \\
0.6025 \\
0.6058 \\
0.6048 \\
0.6040 \\
0.6035 \\
0.6037 \\
0.6041 \\
0.6029 \\
0.6032 \\
0.6028 \\
0.6026\end{array}$ \\
\hline
\end{tabular}

Table 7. Measured and calculated quantities for 0.55 beta ratio, reducer at $210,1 \mathrm{~T} 1$ at $190, \mathrm{flange} t$ aps at position A.

Pipe Diameter $=10.366 \mathrm{~cm}(4.081 \mathrm{in}), 3.8 \mu \mathrm{m}$ Orifice Diameter $=5.7142 \mathrm{~cm}(2.2497 \mathrm{in})$

\begin{tabular}{|c|c|c|c|c|c|c|c|c|}
\hline Run ID & $\begin{array}{l}\text { Pressure } \\
\text { (MPa) }\end{array}$ & $\begin{array}{c}\text { Temperature } \\
\text { (K) }\end{array}$ & $\begin{array}{l}\text { Density } \\
\left(\mathrm{kg} / \mathrm{m}^{3}\right)\end{array}$ & $\begin{array}{c}\text { Dif Press } \\
\text { (kPa) }\end{array}$ & $\begin{array}{c}\text { Flow Rate } \\
(\mathrm{kg} / \mathrm{s})\end{array}$ & $\begin{array}{l}\text { Pipe Re No. } \\
\left(/ 10^{6}\right)\end{array}$ & C & $\mathrm{Cr}_{2}$ \\
\hline $\begin{array}{l}052191-1 \\
052191-2 \\
052191-3 \\
052191-4 \\
052191-5 \\
052191-6 \\
052191-7 \\
052291-1 \\
052291-2 \\
052291-3 \\
052291-4 \\
052291-5 \\
052291-6 \\
052291-7 \\
052291-8\end{array}$ & $\begin{array}{l}3.9498 \\
3.9389 \\
3.8191 \\
3.8185 \\
4.0021 \\
4.0079 \\
4.0336 \\
3.9914 \\
4.0380 \\
3.9597 \\
3.9540 \\
3.7468 \\
3.7541 \\
3.8534 \\
3.8478\end{array}$ & $\begin{array}{l}285.78 \\
285.80 \\
284.47 \\
284.46 \\
285.84 \\
286.40 \\
286.84 \\
286.83 \\
286.89 \\
285.77 \\
285.94 \\
284.73 \\
285.15 \\
285.83 \\
285.21\end{array}$ & $\begin{array}{l}46.96 \\
46.83 \\
45.63 \\
45.63 \\
47.57 \\
47.54 \\
47.77 \\
47.27 \\
47.81 \\
47.08 \\
46.98 \\
44.72 \\
44.73 \\
45.80 \\
45.84\end{array}$ & $\begin{array}{r}13.613 \\
13.488 \\
20.006 \\
19.952 \\
6.394 \\
6.473 \\
2.658 \\
2.681 \\
2.734 \\
5.911 \\
5.884 \\
20.819 \\
20.340 \\
13.798 \\
13.918\end{array}$ & $\begin{array}{l}1.8350 \\
1.8224 \\
2.1827 \\
2.1819 \\
1.2684 \\
1.2760 \\
0.8222 \\
0.8223 \\
0.8372 \\
1.2162 \\
1.2143 \\
2.2228 \\
2.1913 \\
1.8253 \\
1.8346\end{array}$ & $\begin{array}{l}1.2503 \\
1.2419 \\
1.4944 \\
1.4939 \\
0.8636 \\
0.8676 \\
0.5582 \\
0.5586 \\
0.5683 \\
0.8286 \\
0.8270 \\
1.5222 \\
1.4989 \\
1.2450 \\
1.2534\end{array}$ & $\begin{array}{l}0.6026 \\
0.6021 \\
0.5996 \\
0.6003 \\
0.6041 \\
0.6042 \\
0.6063 \\
0.6069 \\
0.6084 \\
0.6056 \\
0.6067 \\
0.6047 \\
0.6030 \\
0.6029 \\
0.6031\end{array}$ & $\begin{array}{l}0.6030 \\
0.6025 \\
0.6003 \\
0.6009 \\
0.6043 \\
0.6044 \\
0.6064 \\
0.6070 \\
0.6085 \\
0.6058 \\
0.6068 \\
0.6053 \\
0.6036 \\
0.6033 \\
0.6035\end{array}$ \\
\hline
\end{tabular}

Table 8. Measured and calculated quantities for 0.55 beta ratio, elbow at 210 , IT1 at 190, flange taps at position A.

Pipe Diameter $=10.366 \mathrm{~cm}(4.081 \mathrm{in}), 3.8 \mu \mathrm{m}$ Orifice Diameter $=5.7142 \mathrm{~cm}(2.2497 \mathrm{in})$

\begin{tabular}{|c|c|c|c|c|c|c|c|c|}
\hline Run ID & $\begin{array}{c}\text { Pressure } \\
\text { (MPa) }\end{array}$ & $\begin{array}{c}\text { Temperature } \\
\text { (K) }\end{array}$ & $\begin{array}{l}\text { Density } \\
\left(\mathrm{kg} / \mathrm{m}^{3}\right)\end{array}$ & $\begin{array}{c}\text { Dif Press } \\
\text { (KPa) }\end{array}$ & $\begin{array}{c}\text { Flow Rate } \\
(\mathrm{kg} / \mathrm{s})\end{array}$ & $\begin{array}{l}\text { Pipe Re No. } \\
\left(/ 10^{6}\right)\end{array}$ & C & $\mathrm{Cr}_{2}$ \\
\hline $\begin{array}{l}060491-1 \\
060491-2 \\
060491-4 \\
060491-5 \\
060491-6 \\
060491-7 \\
060491-8 \\
060591-1 \\
060591-2 \\
060591-3 \\
060591-4 \\
060591-5 \\
060591-6 \\
060591-7 \\
060591-8\end{array}$ & $\begin{array}{l}3.8682 \\
3.8598 \\
4.1087 \\
4.0305 \\
4.0263 \\
3.9302 \\
3.9248 \\
4.0525 \\
4.0510 \\
3.9131 \\
3.9325 \\
3.8089 \\
3.8176 \\
3.9699 \\
3.9650\end{array}$ & $\begin{array}{l}286.06 \\
285.13 \\
286.90 \\
286.06 \\
286.31 \\
285.68 \\
285.33 \\
286.71 \\
286.94 \\
285.01 \\
285.46 \\
284.32 \\
284.96 \\
285.76 \\
286.34\end{array}$ & $\begin{array}{l}45.94 \\
46.00 \\
48.65 \\
47.87 \\
47.78 \\
46.75 \\
46.74 \\
48.02 \\
47.95 \\
46.66 \\
46.81 \\
45.54 \\
45.53 \\
47.20 \\
47.04\end{array}$ & $\begin{array}{r}18.990 \\
18.751 \\
2.879 \\
5.923 \\
5.910 \\
13.031 \\
12.958 \\
3.004 \\
3.002 \\
12.603 \\
12.616 \\
19.069 \\
18.924 \\
6.279 \\
6.439\end{array}$ & $\begin{array}{l}2.1441 \\
2.1334 \\
0.8673 \\
1.2329 \\
1.2304 \\
1.7989 \\
1.7921 \\
0.8801 \\
0.8769 \\
1.7656 \\
1.7695 \\
2.1439 \\
2.1301 \\
1.2543 \\
1.2664\end{array}$ & $\begin{array}{l}1.4614 \\
1.4575 \\
0.5882 \\
0.8387 \\
0.8365 \\
1.2263 \\
1.2228 \\
0.5976 \\
0.5951 \\
1.2058 \\
1.2069 \\
1.4685 \\
1.4566 \\
0.8545 \\
0.8616\end{array}$ & $\begin{array}{l}0.6026 \\
0.6030 \\
0.6089 \\
0.6082 \\
0.6083 \\
0.6052 \\
0.6046 \\
0.6089 \\
0.6072 \\
0.6046 \\
0.6046 \\
0.6039 \\
0.6024 \\
0.6052 \\
0.6044\end{array}$ & $\begin{array}{l}0.6032 \\
0.6036 \\
0.6090 \\
0.6084 \\
0.6084 \\
0.6056 \\
0.6050 \\
0.6090 \\
0.6073 \\
0.6049 \\
0.6050 \\
0.6045 \\
0.6030 \\
0.6053 \\
0.6046\end{array}$ \\
\hline
\end{tabular}


Table 9. Measured and calculated quantities for 0.55 beta ratio, reducer at 170,111 at 150 , flange 2 aps at position A.

Pipe Diameter $=10.366 \mathrm{~cm}(4.081 \mathrm{in}), 3.8 \mu \mathrm{m}$ Orifice Diameter $=5.7142 \mathrm{~cm}(2.2497 \mathrm{in})$

\begin{tabular}{|c|c|c|c|c|c|c|c|c|}
\hline Run ID & $\begin{array}{c}\text { Pressure } \\
\text { (MPa) }\end{array}$ & $\begin{array}{c}\text { Temperature } \\
\text { (K) }\end{array}$ & $\begin{array}{l}\text { Density } \\
\left(\mathrm{kg} / \mathrm{m}^{3}\right)\end{array}$ & $\begin{array}{c}\text { Dif Press } \\
\text { (kPa) }\end{array}$ & $\begin{array}{c}\text { F low Rate } \\
(\mathrm{kg} / \mathrm{s})\end{array}$ & $\begin{array}{l}\text { Pipe Re No. } \\
\left(/ 10^{6}\right)\end{array}$ & C & $\mathrm{Cr}_{2}$ \\
\hline $\begin{array}{l}052891-1 \\
052891-2 \\
052891-3 \\
052891-4 \\
052891-5 \\
052891-6 \\
052891-7 \\
052891-8 \\
052991-1 \\
052991-2 \\
052991-3 \\
052991-4 \\
052991-5 \\
052991-6\end{array}$ & $\begin{array}{l}3.9862 \\
3.9788 \\
3.7978 \\
3.7934 \\
4.0394 \\
4.0295 \\
3.9010 \\
3.8929 \\
3.9271 \\
3.9210 \\
4.0013 \\
4.0107 \\
3.8205 \\
3.8322\end{array}$ & $\begin{array}{l}286.66 \\
286.16 \\
284.97 \\
285.89 \\
286.87 \\
286.97 \\
285.04 \\
285.33 \\
285.27 \\
284.94 \\
286.16 \\
286.13 \\
284.45 \\
285.19\end{array}$ & $\begin{array}{l}47.24 \\
47.24 \\
45.29 \\
45.07 \\
47.83 \\
47.69 \\
46.51 \\
46.36 \\
46.78 \\
46.77 \\
47.51 \\
47.62 \\
45.65 \\
45.66\end{array}$ & $\begin{array}{r}6.315 \\
6.305 \\
20.257 \\
20.502 \\
3.192 \\
3.279 \\
12.892 \\
12.800 \\
13.386 \\
13.325 \\
6.477 \\
6.581 \\
20.410 \\
19.870\end{array}$ & $\begin{array}{l}1.2559 \\
1.2518 \\
2.1894 \\
2.2009 \\
0.9012 \\
0.9122 \\
1.7816 \\
1.7676 \\
1.8189 \\
1.8119 \\
1.2724 \\
1.2866 \\
2.2192 \\
2.1814\end{array}$ & $\begin{array}{l}0.8535 \\
0.8519 \\
1.4975 \\
1.5021 \\
0.6118 \\
0.6192 \\
1.2168 \\
1.2066 \\
1.2412 \\
1.2376 \\
0.8657 \\
0.8753 \\
1.5194 \\
1.4906\end{array}$ & $\begin{array}{l}0.6040 \\
0.6026 \\
0.6000 \\
0.6009 \\
0.6060 \\
0.6060 \\
0.6041 \\
0.6025 \\
0.6035 \\
0.6027 \\
0.6026 \\
0.6037 \\
0.6035 \\
0.6011\end{array}$ & $\begin{array}{l}0.6042 \\
0.6028 \\
0.6006 \\
0.6016 \\
0.6061 \\
0.6061 \\
0.6045 \\
0.6029 \\
0.6039 \\
0.6031 \\
0.6028 \\
0.6039 \\
0.6041 \\
0.6018\end{array}$ \\
\hline
\end{tabular}

Table 10. Messured and calculated quantities for 0.55 beta ratio, elbow at 17D, IT1 at 15D, flange taps at position A.

Pipe Diameter $=10.366 \mathrm{~cm}(4.081 \mathrm{in}), 3.8 \mu \mathrm{m}$ Orifice Diameter $=5.7142 \mathrm{~cm}(2.2497 \mathrm{in})$

\begin{tabular}{|c|c|c|c|c|c|c|c|c|}
\hline Run ID & $\begin{array}{l}\text { Pressure } \\
\text { (MPa) }\end{array}$ & $\begin{array}{c}\text { Temperature } \\
\text { (K) }\end{array}$ & $\begin{array}{l}\text { Density } \\
\left(\mathrm{kg} / \mathrm{m}^{3}\right)\end{array}$ & $\begin{array}{c}\text { Dif Press } \\
\text { (kPa) }\end{array}$ & $\begin{array}{l}\text { Flow Rate } \\
(\mathrm{kg} / \mathrm{s})\end{array}$ & $\begin{array}{l}\text { Pipe Re No. } \\
\left(/ 10^{6}\right)\end{array}$ & C & $\mathrm{CY}_{2}$ \\
\hline $\begin{array}{l}053091-1 \\
053091-2 \\
053091-3 \\
053091-4 \\
053091-5 \\
053091-6 \\
053091-7 \\
053091-8 \\
053191-1 \\
053191-2 \\
053191-3 \\
053191-4 \\
053191-5 \\
053191-6 \\
053191-7 \\
053191-8\end{array}$ & $\begin{array}{l}4.0538 \\
4.0506 \\
3.8670 \\
3.8543 \\
4.0823 \\
4.0730 \\
3.9193 \\
3.9155 \\
3.8717 \\
3.8704 \\
4.0123 \\
4.0107 \\
3.7868 \\
3.7735 \\
3.9397 \\
3.9642\end{array}$ & $\begin{array}{l}286.24 \\
286.75 \\
284.45 \\
285.38 \\
286.43 \\
286.62 \\
285.96 \\
284.94 \\
286.37 \\
285.21 \\
286.53 \\
286.66 \\
285.59 \\
285.42 \\
286.04 \\
286.11\end{array}$ & $\begin{array}{l}48.12 \\
47.98 \\
46.21 \\
45.89 \\
48.42 \\
48.27 \\
46.56 \\
46.70 \\
45.92 \\
46.12 \\
47.57 \\
47.53 \\
45.05 \\
44.92 \\
46.79 \\
47.08\end{array}$ & $\begin{array}{r}5.731 \\
5.732 \\
19.296 \\
18.913 \\
3.052 \\
3.120 \\
13.443 \\
13.276 \\
13.427 \\
13.350 \\
3.085 \\
3.134 \\
18.965 \\
19.682 \\
6.467 \\
6.568\end{array}$ & $\begin{array}{l}1.2086 \\
1.2044 \\
2.1679 \\
2.1351 \\
0.8856 \\
0.8964 \\
1.8254 \\
1.8106 \\
1.8072 \\
1.8041 \\
0.8846 \\
0.8910 \\
2.1217 \\
2.1593 \\
1.2654 \\
1.2784\end{array}$ & $\begin{array}{l}0.8216 \\
0.8177 \\
1.4835 \\
1.4579 \\
0.6015 \\
0.6086 \\
1.2437 \\
1.2367 \\
1.2308 \\
1.2322 \\
0.6012 \\
0.6054 \\
1.4492 \\
1.4757 \\
0.8618 \\
0.8702\end{array}$ & $\begin{array}{l}0.6046 \\
0.6033 \\
0.6027 \\
0.6016 \\
0.6053 \\
0.6069 \\
0.6058 \\
0.6038 \\
0.6043 \\
0.6037 \\
0.6068 \\
0.6065 \\
0.6025 \\
0.6028 \\
0.6042 \\
0.6039\end{array}$ & $\begin{array}{l}0.6048 \\
0.6034 \\
0.6033 \\
0.6022 \\
0.6054 \\
0.6070 \\
0.6062 \\
0.6042 \\
0.6047 \\
0.6042 \\
0.6068 \\
0.6066 \\
0.6031 \\
0.6034 \\
0.6044 \\
0.6041\end{array}$ \\
\hline
\end{tabular}

Table 11. Measured and calculated quantities for 0.55 beta ratio, reducer at 130 , IT1 at 110 , flange taps at position A.

Pipe Diameter $=10.366 \mathrm{~cm}(4.081 \mathrm{in}), 3.8 \mu \mathrm{m}$ Orifice Diameter $=5.7142 \mathrm{~cm}(2.2497 \mathrm{in})$

\begin{tabular}{|c|c|c|c|c|c|c|c|c|}
\hline Run ID & $\begin{array}{c}\text { Pressure } \\
\text { (MPa) }\end{array}$ & $\begin{array}{c}\text { Temperature } \\
\text { (K) }\end{array}$ & $\begin{array}{l}\text { Density } \\
\left(\mathrm{kg} / \mathrm{m}^{3}\right)\end{array}$ & $\begin{array}{c}\text { Dif Press } \\
\text { (KPa) }\end{array}$ & $\begin{array}{c}\text { Flow Rate } \\
(\mathrm{kg} / \mathrm{s})\end{array}$ & $\begin{array}{c}\text { Pipe Re No. } \\
\left(/ 10^{6}\right)\end{array}$ & C & $\mathrm{CY}_{2}$ \\
\hline $\begin{array}{l}052391-1 \\
052391-2 \\
052391-3 \\
052391-4 \\
052391-5 \\
052391-6 \\
052391-7 \\
052391-8 \\
052491-1 \\
052491-2 \\
052491-3 \\
052491-4 \\
052491-5 \\
052491-6 \\
052491-7 \\
052491-8\end{array}$ & $\begin{array}{l}3.9370 \\
3.9393 \\
3.8491 \\
3.8541 \\
4.0068 \\
4.0087 \\
4.0851 \\
4.0940 \\
3.7480 \\
3.7512 \\
3.9202 \\
3.9150 \\
3.8403 \\
3.8370 \\
3.9876 \\
3.9834\end{array}$ & $\begin{array}{l}286.13 \\
285.19 \\
286.24 \\
284.54 \\
286.26 \\
286.41 \\
286.68 \\
286.98 \\
285.67 \\
285.22 \\
286.06 \\
286.23 \\
285.97 \\
286.29 \\
286.46 \\
286.49\end{array}$ & $\begin{array}{l}46.75 \\
46.94 \\
45.68 \\
46.04 \\
47.55 \\
47.55 \\
48.41 \\
48.46 \\
44.57 \\
44.69 \\
46.56 \\
46.47 \\
45.62 \\
45.52 \\
47.29 \\
47.23\end{array}$ & $\begin{array}{r}12.906 \\
12.847 \\
19.273 \\
18.991 \\
5.983 \\
6.083 \\
2.951 \\
2.970 \\
19.878 \\
19.697 \\
6.784 \\
6.847 \\
13.447 \\
13.426 \\
3.369 \\
3.445\end{array}$ & $\begin{array}{l}1.7766 \\
1.7800 \\
2.1447 \\
2.1396 \\
1.2236 \\
1.2330 \\
0.8692 \\
0.8761 \\
2.1586 \\
2.1430 \\
1.2891 \\
1.2936 \\
1.7904 \\
1.7919 \\
0.9179 \\
0.9271\end{array}$ & $\begin{array}{l}1.2097 \\
1.2148 \\
1.4615 \\
1.4640 \\
0.8322 \\
0.8383 \\
0.5900 \\
0.5942 \\
1.4748 \\
1.4657 \\
0.8781 \\
0.8808 \\
1.2210 \\
1.2211 \\
0.6241 \\
0.6303\end{array}$ & $\begin{array}{l}0.6006 \\
0.6019 \\
0.6000 \\
0.6007 \\
0.6026 \\
0.6022 \\
0.6042 \\
0.6067 \\
0.6019 \\
0.5996 \\
0.6025 \\
0.6024 \\
0.6002 \\
0.6018 \\
0.6042 \\
0.6038\end{array}$ & $\begin{array}{l}0.6010 \\
0.6023 \\
0.6006 \\
0.6012 \\
0.6028 \\
0.6024 \\
0.6043 \\
0.6068 \\
0.6026 \\
0.6002 \\
0.6027 \\
0.6026 \\
0.6006 \\
0.6022 \\
0.6043 \\
0.6039\end{array}$ \\
\hline
\end{tabular}


Table 12. Measured and calculated quantities for 0.55 beta ratio, elbow at 130, IT1 at 110 , flange taps at position A.

Pipe Diameter $=10.366 \mathrm{~cm}(4.081 \mathrm{in}), 3.8 \mu \mathrm{m}$ Orifice Diameter $=5.7142 \mathrm{~cm}(2.2497 \mathrm{in})$

\begin{tabular}{|c|c|c|c|c|c|c|c|c|}
\hline Run I0 & $\begin{array}{c}\text { Pressure } \\
\text { (MPa) }\end{array}$ & $\begin{array}{c}\text { Temperature } \\
\text { (K) }\end{array}$ & $\begin{array}{l}\text { Density } \\
\left(\mathrm{kg} / \mathrm{m}^{3}\right)\end{array}$ & $\begin{array}{c}\text { Dif Press } \\
\text { (kPa) }\end{array}$ & $\begin{array}{c}\text { Flow Rate } \\
(\mathrm{kg} / \mathrm{s})\end{array}$ & $\begin{array}{c}\text { Pipe Re No. } \\
\left(/ 10^{6}\right)\end{array}$ & C & $\mathrm{Cr}_{2}$ \\
\hline $\begin{array}{l}060691-1 \\
060691-2 \\
060691-3 \\
060691-4 \\
060691-5 \\
060691-6 \\
060691-7 \\
060691-8 \\
060791-1 \\
060791-2 \\
060791-3 \\
060791-4 \\
060791-5 \\
060791-6 \\
060791-7 \\
060791-8\end{array}$ & $\begin{array}{l}4.0382 \\
4.0356 \\
4.0905 \\
4.0953 \\
3.9388 \\
3.9353 \\
3.8458 \\
3.8489 \\
4.0083 \\
4.0092 \\
3.8623 \\
3.8622 \\
3.9321 \\
3.9321 \\
3.7607 \\
3.7581\end{array}$ & $\begin{array}{l}286.59 \\
286.26 \\
286.65 \\
286.72 \\
285.10 \\
286.27 \\
284.68 \\
285.51 \\
286.34 \\
286.48 \\
284.93 \\
284.69 \\
285.89 \\
285.96 \\
285.80 \\
285.38\end{array}$ & $\begin{array}{l}47.87 \\
47.90 \\
48.48 \\
48.52 \\
46.95 \\
46.70 \\
45.91 \\
45.80 \\
47.56 \\
47.54 \\
46.07 \\
46.11 \\
46.73 \\
46.72 \\
44.70 \\
44.74\end{array}$ & $\begin{array}{r}5.910 \\
5.889 \\
3.189 \\
3.208 \\
13.179 \\
13.183 \\
19.083 \\
18.900 \\
2.706 \\
2.708 \\
12.960 \\
12.871 \\
6.414 \\
6.463 \\
19.983 \\
19.726\end{array}$ & $\begin{array}{l}1.2230 \\
1.2213 \\
0.9053 \\
0.9106 \\
1.8031 \\
1.7982 \\
2.1405 \\
2.1274 \\
0.8241 \\
0.8266 \\
1.7738 \\
1.7668 \\
1.2569 \\
1.2648 \\
2.1651 \\
2.1511\end{array}$ & $\begin{array}{l}0.8308 \\
0.8303 \\
0.6145 \\
0.6180 \\
1.2308 \\
1.2240 \\
1.4642 \\
1.4523 \\
0.5604 \\
0.5619 \\
1.2124 \\
1.2083 \\
0.8564 \\
0.8617 \\
1.4785 \\
1.4705\end{array}$ & $\begin{array}{l}0.6040 \\
0.6041 \\
0.6050 \\
0.6064 \\
0.6019 \\
0.6018 \\
0.6003 \\
0.6002 \\
0.6037 \\
0.6053 \\
0.6028 \\
0.6022 \\
0.6031 \\
0.6046 \\
0.6013 \\
0.6010\end{array}$ & $\begin{array}{l}0.6042 \\
0.6042 \\
0.6051 \\
0.6065 \\
0.6023 \\
0.6022 \\
0.6009 \\
0.6008 \\
0.6038 \\
0.6054 \\
0.6032 \\
0.6026 \\
0.6033 \\
0.6048 \\
0.6019 \\
0.6016\end{array}$ \\
\hline
\end{tabular}

Table 13. Measured and calculated quantities for 0.67 beta ratio, reducer at $210,1 T 1$ at 190 , flange taps at position A.

Pipe Diameter $=10.366 \mathrm{~cm}(4.081 \mathrm{in}), 3.8 \mu \mathrm{m}$ Orifice Diameter $=6.9840 \mathrm{~cm}(2.7496 \mathrm{in})$

\begin{tabular}{|c|c|c|c|c|c|c|c|c|}
\hline Run 10 & $\begin{array}{c}\text { Pressure } \\
\text { (MPa) }\end{array}$ & $\begin{array}{c}\text { Temperature } \\
\text { (K) }\end{array}$ & $\begin{array}{l}\text { Oensity } \\
\left(\mathrm{kg} / \mathrm{m}^{3}\right)\end{array}$ & $\begin{array}{c}\text { Dif Press } \\
\text { (KPa) }\end{array}$ & $\begin{array}{c}\text { Flow Rate } \\
(\mathrm{kg} / \mathrm{s})\end{array}$ & $\begin{array}{l}\text { Pipe Re No. } \\
\left(/ 10^{6}\right)\end{array}$ & C & $\mathrm{Cr}_{2}$ \\
\hline $\begin{array}{l}052191-1 \\
052191-2 \\
052191-3 \\
052191-4 \\
052191-5 \\
052191-6 \\
052191-7 \\
052191-8 \\
052191-9 \\
052191-10 \\
052191-11 \\
052291-1 \\
052291-2 \\
052291-3 \\
052291-4 \\
052291-5 \\
052291-6 \\
052291-7 \\
052291-8\end{array}$ & $\begin{array}{l}3.9866 \\
3.9894 \\
3.9091 \\
3.9204 \\
4.0162 \\
4.0117 \\
4.0125 \\
3.8476 \\
3.8523 \\
3.9839 \\
3.9018 \\
3.7951 \\
3.8027 \\
3.9590 \\
3.9539 \\
3.8511 \\
3.8479 \\
3.9273 \\
3.9199\end{array}$ & $\begin{array}{l}285.74 \\
285.71 \\
285.09 \\
286.09 \\
286.46 \\
286.27 \\
286.27 \\
284.84 \\
286.22 \\
285.49 \\
283.86 \\
285.84 \\
284.67 \\
285.94 \\
286.24 \\
284.94 \\
285.64 \\
285.83 \\
285.31\end{array}$ & $\begin{array}{l}47.41 \\
47.45 \\
46.60 \\
46.55 \\
47.63 \\
47.61 \\
47.62 \\
45.91 \\
45.72 \\
47.42 \\
46.74 \\
45.10 \\
45.40 \\
47.04 \\
46.93 \\
45.93 \\
45.77 \\
46.68 \\
46.69\end{array}$ & $\begin{array}{l}3.876 \\
3.829 \\
5.938 \\
5.924 \\
2.816 \\
2.810 \\
2.807 \\
7.485 \\
7.385 \\
3.204 \\
2.975 \\
7.533 \\
7.409 \\
2.720 \\
2.735 \\
6.058 \\
6.035 \\
4.049 \\
4.081\end{array}$ & $\begin{array}{l}1.5791 \\
1.5697 \\
1.9336 \\
1.9279 \\
1.3558 \\
1.3601 \\
1.3557 \\
2.1589 \\
2.1374 \\
1.4418 \\
1.3799 \\
2.1380 \\
2.1287 \\
1.3260 \\
1.3283 \\
1.9379 \\
1.9301 \\
1.6035 \\
1.6127\end{array}$ & $\begin{array}{l}1.0756 \\
1.0693 \\
1.3204 \\
1.3131 \\
0.9216 \\
0.9250 \\
0.9220 \\
1.4762 \\
1.4566 \\
0.9827 \\
0.9452 \\
1.4593 \\
1.4570 \\
0.9030 \\
0.9040 \\
1.3247 \\
1.3172 \\
1.0928 \\
1.1005\end{array}$ & $\begin{array}{l}0.6059 \\
0.6058 \\
0.6046 \\
0.6038 \\
0.6089 \\
0.6117 \\
0.6101 \\
0.6057 \\
0.6050 \\
0.6085 \\
0.6088 \\
0.6032 \\
0.6036 \\
0.6098 \\
0.6099 \\
0.6043 \\
0.6040 \\
0.6067 \\
0.6077\end{array}$ & $\begin{array}{l}0.6060 \\
0.6059 \\
0.6047 \\
0.6039 \\
0.6090 \\
0.6117 \\
0.6101 \\
0.6059 \\
0.6052 \\
0.6086 \\
0.6089 \\
0.6034 \\
0.6038 \\
0.6099 \\
0.6100 \\
0.6044 \\
0.6041 \\
0.6068 \\
0.6078\end{array}$ \\
\hline
\end{tabular}

Table 14. Measured and calculated quantities for 0.67 beta ratio, elbow at $210, I T 1$ at 190 , flange taps at position A.

Pipe Diameter $=10.366 \mathrm{~cm}(4.081 \mathrm{in}), 3.8 \mu \mathrm{m}$ Orifice Diameter $=6.9840 \mathrm{~cm}(2.7496 \mathrm{in})$

\begin{tabular}{|c|c|c|c|c|c|c|c|c|}
\hline Run 10 & $\begin{array}{l}\text { Pressure } \\
\text { (MPa) }\end{array}$ & $\begin{array}{c}\text { Temperature } \\
\text { (K) }\end{array}$ & $\begin{array}{l}\text { Density } \\
\left(\mathrm{kg} / \mathrm{m}^{3}\right)\end{array}$ & $\begin{array}{l}\text { Dif Press } \\
\text { (kPa) }\end{array}$ & $\begin{array}{c}\text { Flow Rate } \\
(\mathrm{kg} / \mathrm{s})\end{array}$ & $\begin{array}{l}\text { Pipe Re No. } \\
\left(/ 10^{6}\right)\end{array}$ & C & $\mathrm{Cr}_{2}$ \\
\hline $\begin{array}{l}060491-1 \\
060491-2 \\
060491-3 \\
060491-4 \\
060491-5 \\
060491-6 \\
060491-7 \\
060491-8 \\
060591-1 \\
060591-2 \\
060591-3 \\
060591-4 \\
060591-5 \\
060591-6 \\
060591-7 \\
060591-8\end{array}$ & $\begin{array}{l}3.8888 \\
3.8841 \\
3.8258 \\
3.8258 \\
3.9470 \\
3.9457 \\
3.9868 \\
3.9881 \\
3.9744 \\
3.9730 \\
3.9013 \\
3.8995 \\
3.9903 \\
4.0066 \\
3.8420 \\
3.8405\end{array}$ & $\begin{array}{l}286.46 \\
286.57 \\
284.57 \\
286.36 \\
285.72 \\
285.36 \\
285.78 \\
285.66 \\
286.03 \\
286.53 \\
285.73 \\
285.75 \\
285.88 \\
285.82 \\
286.14 \\
285.01\end{array}$ & $\begin{array}{l}46.11 \\
46.04 \\
45.69 \\
45.38 \\
46.94 \\
46.99 \\
47.40 \\
47.44 \\
47.21 \\
47.10 \\
46.39 \\
46.37 \\
47.43 \\
47.63 \\
45.61 \\
45.79\end{array}$ & $\begin{array}{l}6.010 \\
6.005 \\
7.572 \\
7.547 \\
4.080 \\
4.121 \\
2.638 \\
2.613 \\
3.998 \\
3.995 \\
5.827 \\
5.799 \\
2.685 \\
2.697 \\
7.355 \\
7.255\end{array}$ & $\begin{array}{l}1.9357 \\
1.9349 \\
2.1652 \\
2.1488 \\
1.6081 \\
1.6167 \\
1.3024 \\
1.2993 \\
1.5981 \\
1.5942 \\
1.9078 \\
1.9040 \\
1.3142 \\
1.3226 \\
2.1274 \\
2.1135\end{array}$ & $\begin{array}{l}1.3178 \\
1.3169 \\
1.4819 \\
1.4643 \\
1.0960 \\
1.1028 \\
0.8870 \\
0.8852 \\
1.0879 \\
1.0840 \\
1.3009 \\
1.2982 \\
0.8948 \\
0.9005 \\
1.4502 \\
1.4447\end{array}$ & $\begin{array}{l}0.6047 \\
0.6052 \\
0.6054 \\
0.6038 \\
0.6044 \\
0.6043 \\
0.6059 \\
0.6071 \\
0.6051 \\
0.6044 \\
0.6035 \\
0.6039 \\
0.6058 \\
0.6070 \\
0.6040 \\
0.6030\end{array}$ & $\begin{array}{l}0.6049 \\
0.6054 \\
0.6056 \\
0.6040 \\
0.6045 \\
0.6044 \\
0.6059 \\
0.6071 \\
0.6052 \\
0.6045 \\
0.6036 \\
0.6041 \\
0.6058 \\
0.6070 \\
0.6042 \\
0.6032\end{array}$ \\
\hline
\end{tabular}


Table 15. Measured and calculated quantities for 0.67 beta ratio, reducer at 170, 171 at 150 , flange taps at position A. Pipe Oiameter $=10.366 \mathrm{~cm}(4.081 \mathrm{in}), 3.8 \mu \mathrm{m}$ Orifice 0 iameter $=6.9840 \mathrm{~cm}(2.7496 \mathrm{in})$

\begin{tabular}{|c|c|c|c|c|c|c|c|c|}
\hline Run 10 & $\begin{array}{l}\text { Pressure } \\
\text { (MPa) }\end{array}$ & $\begin{array}{c}\text { Temperature } \\
\text { (K) }\end{array}$ & $\begin{array}{l}\text { Density } \\
\left(\mathrm{kg} / \mathrm{m}^{3}\right)\end{array}$ & $\begin{array}{l}\text { Dif Press } \\
\text { (kPa) }\end{array}$ & $\begin{array}{c}\text { Flow Rate } \\
\text { (kg/s) }\end{array}$ & $\begin{array}{c}\text { Pipe Re Ho. } \\
\left(/ 10^{6}\right)\end{array}$ & C & $\mathrm{CY}_{2}$ \\
\hline $\begin{array}{l}052891-1 \\
052891-2 \\
052891-3 \\
052891-4 \\
052891-5 \\
052891-6 \\
052891-7 \\
052891-8 \\
052991-1 \\
052991-2 \\
052991-3 \\
052991-4 \\
052991-5 \\
052991-6 \\
052991-7 \\
052991-8\end{array}$ & $\begin{array}{l}3.8564 \\
3.8503 \\
3.9290 \\
3.9236 \\
3.7893 \\
3.8048 \\
3.9458 \\
3.9446 \\
3.9127 \\
3.9079 \\
3.9641 \\
3.9687 \\
4.0153 \\
4.0218 \\
3.8501 \\
3.8532\end{array}$ & $\begin{array}{l}285.03 \\
285.16 \\
286.42 \\
285.76 \\
284.70 \\
284.94 \\
286.43 \\
286.09 \\
286.21 \\
285.19 \\
285.39 \\
285.85 \\
286.28 \\
286.06 \\
285.06 \\
285.14\end{array}$ & $\begin{array}{l}45.98 \\
45.88 \\
46.60 \\
46.65 \\
45.23 \\
45.38 \\
46.80 \\
46.84 \\
46.44 \\
46.57 \\
47.20 \\
47.17 \\
47.65 \\
47.77 \\
45.90 \\
45.92\end{array}$ & $\begin{array}{l}5.968 \\
5.945 \\
3.766 \\
3.781 \\
7.661 \\
7.557 \\
2.654 \\
2.708 \\
5.887 \\
5.847 \\
4.039 \\
4.071 \\
2.510 \\
2.520 \\
7.844 \\
7.731\end{array}$ & $\begin{array}{l}1.9236 \\
1.9156 \\
1.5370 \\
1.5401 \\
2.1609 \\
2.1455 \\
1.2937 \\
1.3089 \\
1.9108 \\
1.9097 \\
1.6013 \\
1.6042 \\
1.2702 \\
1.2764 \\
2.2018 \\
2.1837\end{array}$ & $\begin{array}{l}1.3145 \\
1.3088 \\
1.0459 \\
1.0498 \\
1.4791 \\
1.4675 \\
0.8802 \\
0.8913 \\
1.3012 \\
1.3037 \\
1.0919 \\
1.0926 \\
0.8638 \\
0.8684 \\
1.5047 \\
1.4920\end{array}$ & $\begin{array}{l}0.6039 \\
0.6032 \\
0.6034 \\
0.6032 \\
0.6037 \\
0.6026 \\
0.6038 \\
0.6045 \\
0.6010 \\
0.6019 \\
0.6032 \\
0.6021 \\
0.6041 \\
0.6052 \\
0.6035 \\
0.6027\end{array}$ & $\begin{array}{l}0.6041 \\
0.6034 \\
0.6035 \\
0.6033 \\
0.6039 \\
0.6028 \\
0.6039 \\
0.6046 \\
0.6011 \\
0.6021 \\
0.6033 \\
0.6022 \\
0.6042 \\
0.6053 \\
0.6037 \\
0.6030\end{array}$ \\
\hline
\end{tabular}

Table 16. Measured and calculated quantities for 0.67 beta ratio, elbow at 170, 1T1 at 15D, flange taps at position A.

Pipe Oiameter $=10.366 \mathrm{~cm}(4.081 \mathrm{in}), 3.8 \mu \mathrm{m}$ Orifice 0 iameter $=6.9840 \mathrm{~cm}(2.7496 \mathrm{in})$

\begin{tabular}{|c|c|c|c|c|c|c|c|c|}
\hline Run 10 & $\begin{array}{l}\text { Pressure } \\
\text { (MPB) }\end{array}$ & $\begin{array}{c}\text { Temperature } \\
\text { (K) }\end{array}$ & $\begin{array}{l}\text { Oensity } \\
\left(\mathrm{kg} / \mathrm{m}^{3}\right)\end{array}$ & $\begin{array}{c}\text { Dif Press } \\
\text { (kPa) }\end{array}$ & $\begin{array}{c}\text { Flow Rate } \\
(\mathrm{kg} / \mathrm{s})\end{array}$ & $\begin{array}{c}\text { Pipe Re No. } \\
\left(/ 10^{6}\right)\end{array}$ & C & $\mathrm{CY}_{2}$ \\
\hline $\begin{array}{l}053091-1 \\
053091-2 \\
053091-3 \\
053091-4 \\
053091-5 \\
053091-6 \\
053091-7 \\
053091-8 \\
053191-1 \\
053191-2 \\
053191-4 \\
053191-5 \\
053191-6 \\
053191-7 \\
053191-8 \\
053191-9\end{array}$ & $\begin{array}{l}3.9595 \\
3.9690 \\
3.9834 \\
3.9798 \\
3.8788 \\
3.8791 \\
3.8189 \\
3.8250 \\
3.9485 \\
3.9459 \\
3.8029 \\
3.7965 \\
3.8624 \\
3.8480 \\
3.9508 \\
3.9510\end{array}$ & $\begin{array}{l}285.70 \\
285.08 \\
285.77 \\
286.22 \\
286.31 \\
285.56 \\
284.32 \\
285.36 \\
286.13 \\
285.71 \\
285.47 \\
284.20 \\
285.66 \\
285.41 \\
285.65 \\
286.05\end{array}$ & $\begin{array}{l}47.09 \\
47.32 \\
47.36 \\
47.24 \\
46.02 \\
46.16 \\
45.66 \\
45.55 \\
46.88 \\
46.93 \\
45.26 \\
45.41 \\
45.94 \\
45.81 \\
47.00 \\
46.93\end{array}$ & $\begin{array}{l}4.057 \\
4.060 \\
2.565 \\
2.582 \\
5.853 \\
5.766 \\
7.440 \\
7.351 \\
3.912 \\
3.915 \\
7.533 \\
7.670 \\
6.049 \\
6.087 \\
2.679 \\
2.713\end{array}$ & $\begin{array}{l}1.6127 \\
1.6131 \\
1.2814 \\
1.2873 \\
1.9058 \\
1.8967 \\
2.1421 \\
2.1233 \\
1.5695 \\
1.5704 \\
2.1385 \\
2.1652 \\
1.9321 \\
1.9344 \\
1.3040 \\
1.3099\end{array}$ & $\begin{array}{l}1.0989 \\
1.1007 \\
0.8728 \\
0.8759 \\
1.2980 \\
1.2942 \\
1.4671 \\
1.4505 \\
1.0685 \\
1.0703 \\
1.4609 \\
1.4838 \\
1.3183 \\
1.3209 \\
0.8888 \\
0.8919\end{array}$ & $\begin{array}{l}0.6069 \\
0.6053 \\
0.6047 \\
0.6064 \\
0.6039 \\
0.6047 \\
0.6044 \\
0.6035 \\
0.6028 \\
0.6026 \\
0.6023 \\
0.6034 \\
0.6028 \\
0.6025 \\
0.6045 \\
0.6039\end{array}$ & $\begin{array}{l}0.6070 \\
0.6054 \\
0.6048 \\
0.6064 \\
0.6041 \\
0.6048 \\
0.6047 \\
0.6037 \\
0.6029 \\
0.6027 \\
0.6025 \\
0.6036 \\
0.6030 \\
0.6026 \\
0.6046 \\
0.6039\end{array}$ \\
\hline
\end{tabular}

Table 17. Measured and calculated quantities for 0.67 beta ratio, reducer at 13D, IT1 at $11 \mathrm{D}$, flange taps at position A.

Pipe 0iameter $=10.366 \mathrm{~cm}(4.081 \mathrm{in}), 3.8 \mu \mathrm{m}$ Orifice 0 iameter $=6.9840 \mathrm{~cm}(2.7496 \mathrm{in})$

\begin{tabular}{|c|c|c|c|c|c|c|c|c|}
\hline Run 10 & $\begin{array}{c}\text { Pressure } \\
\text { (MPB) }\end{array}$ & $\begin{array}{c}\text { Temperature } \\
\text { (K) }\end{array}$ & $\begin{array}{l}\text { Oensity } \\
\left(\mathrm{kg} / \mathrm{m}^{3}\right)\end{array}$ & $\begin{array}{l}\text { Dif Press } \\
\text { (KPa) }\end{array}$ & $\begin{array}{c}\text { Flow Rate } \\
(\mathrm{kg} / \mathrm{s})\end{array}$ & $\begin{array}{c}\text { Pipe Re No. } \\
\left(/ 10^{6}\right)\end{array}$ & C & $\mathrm{CY}_{2}$ \\
\hline $\begin{array}{l}052391-1 \\
052391-2 \\
052391-3 \\
052391-4 \\
052391-5 \\
052391-6 \\
052391-7 \\
052391-8 \\
052391-9 \\
052391-10 \\
052491-1 \\
052491-2 \\
052491-3 \\
052491-4 \\
052491-5 \\
052491-6 \\
052491-7 \\
052491-8\end{array}$ & $\begin{array}{l}3.9725 \\
3.9681 \\
4.0044 \\
4.0001 \\
3.9013 \\
3.9151 \\
3.8232 \\
3.8221 \\
3.9536 \\
3.9521 \\
3.8464 \\
3.8414 \\
3.9306 \\
3.9282 \\
3.8946 \\
3.8955 \\
3.7585 \\
3.7592\end{array}$ & $\begin{array}{l}285.91 \\
286.54 \\
286.18 \\
285.94 \\
285.29 \\
285.49 \\
285.96 \\
285.88 \\
285.94 \\
285.32 \\
285.89 \\
285.44 \\
286.23 \\
286.13 \\
285.39 \\
285.89 \\
285.17 \\
284.37\end{array}$ & $\begin{array}{l}47.21 \\
47.04 \\
47.54 \\
47.53 \\
46.47 \\
46.60 \\
45.42 \\
45.42 \\
46.98 \\
47.08 \\
45.71 \\
45.73 \\
46.65 \\
46.64 \\
46.37 \\
46.29 \\
44.78 \\
44.93\end{array}$ & $\begin{array}{l}4.157 \\
4.159 \\
2.791 \\
2.782 \\
5.949 \\
5.935 \\
7.842 \\
7.791 \\
4.107 \\
4.157 \\
5.780 \\
5.773 \\
2.533 \\
2.544 \\
3.968 \\
3.965 \\
7.820 \\
7.710\end{array}$ & $\begin{array}{l}1.6307 \\
1.6254 \\
1.3387 \\
1.3354 \\
1.9247 \\
1.9234 \\
2.1882 \\
2.1720 \\
1.6064 \\
1.6176 \\
1.8754 \\
1.8721 \\
1.2593 \\
1.2596 \\
1.5665 \\
1.5647 \\
2.1614 \\
2.1496\end{array}$ & $\begin{array}{l}1.1105 \\
1.1053 \\
0.9107 \\
0.9090 \\
1.3138 \\
1.3121 \\
1.4926 \\
1.4819 \\
1.0941 \\
1.1034 \\
1.2791 \\
1.2784 \\
0.8573 \\
0.8578 \\
1.0691 \\
1.0666 \\
1.4784 \\
1.4732\end{array}$ & $\begin{array}{l}0.6054 \\
0.6044 \\
0.6045 \\
0.6041 \\
0.6020 \\
0.6016 \\
0.6030 \\
0.6005 \\
0.6016 \\
0.6015 \\
0.6001 \\
0.5993 \\
0.6026 \\
0.6015 \\
0.6007 \\
0.6007 \\
0.6007 \\
0.6007\end{array}$ & $\begin{array}{l}0.6056 \\
0.6045 \\
0.6046 \\
0.6041 \\
0.6022 \\
0.6017 \\
0.6032 \\
0.6007 \\
0.6017 \\
0.6016 \\
0.6003 \\
0.5995 \\
0.6026 \\
0.6016 \\
0.6008 \\
0.6008 \\
0.6009 \\
0.6009\end{array}$ \\
\hline
\end{tabular}


Table 18. Measured and calculated quantities for 0.67 beta ratio, elbow at 130,111 at 110 , flange taps at position A. Pipe Diameter $=10.366 \mathrm{~cm}(4.081 \mathrm{in}), 3.8 \mu \mathrm{m}$ Orifice Diameter $=6.9840 \mathrm{~cm}(2.7496 \mathrm{in})$

\begin{tabular}{|c|c|c|c|c|c|c|c|c|}
\hline Run 10 & $\begin{array}{l}\text { Pressure } \\
\text { (MPa) }\end{array}$ & $\begin{array}{c}\text { Temperature } \\
\text { (K) }\end{array}$ & $\begin{array}{l}\text { Density } \\
\left(\mathrm{kg} / \mathrm{m}^{3}\right)\end{array}$ & $\begin{array}{l}\text { Dif Press } \\
\quad(\mathrm{kPa})\end{array}$ & $\begin{array}{l}\text { Flow Rate } \\
(\mathrm{kg} / \mathrm{s})\end{array}$ & $\begin{array}{l}\text { Pipe Re No. } \\
\left(/ 10^{6}\right)\end{array}$ & C & $\mathrm{CY}_{2}$ \\
\hline $\begin{array}{l}060691-2 \\
060691-3 \\
060691-4 \\
060691-5 \\
060691-6 \\
060691-7 \\
060691-8 \\
060691-9 \\
060791-3 \\
060791-4 \\
060791-5 \\
060791-6 \\
060791-7 \\
060791-8 \\
060791-9\end{array}$ & $\begin{array}{l}4.0051 \\
3.9696 \\
3.9646 \\
3.8922 \\
3.8900 \\
3.8269 \\
3.8247 \\
3.9595 \\
3.9493 \\
3.9485 \\
3.7819 \\
3.7825 \\
3.9040 \\
3.9000 \\
3.8358\end{array}$ & $\begin{array}{l}286.45 \\
285.96 \\
285.79 \\
285.98 \\
284.51 \\
284.73 \\
286.04 \\
285.78 \\
285.77 \\
285.73 \\
285.93 \\
285.51 \\
285.36 \\
285.47 \\
286.29\end{array}$ & $\begin{array}{l}47.50 \\
47.16 \\
47.14 \\
46.24 \\
46.48 \\
45.68 \\
45.42 \\
47.08 \\
46.96 \\
46.95 \\
44.93 \\
45.01 \\
46.49 \\
46.42 \\
45.51\end{array}$ & $\begin{array}{l}2.533 \\
3.900 \\
3.891 \\
5.989 \\
5.932 \\
7.638 \\
7.615 \\
3.511 \\
2.535 \\
2.534 \\
7.896 \\
7.805 \\
4.279 \\
4.315 \\
6.190\end{array}$ & $\begin{array}{l}1.2798 \\
1.5782 \\
1.5755 \\
1.9297 \\
1.9211 \\
2.1601 \\
2.1508 \\
1.4921 \\
1.2708 \\
1.2673 \\
2.1827 \\
2.1684 \\
1.6356 \\
1.6441 \\
1.9427\end{array}$ & $\begin{array}{l}0.8700 \\
1.0746 \\
1.0733 \\
1.3151 \\
1.3140 \\
1.4778 \\
1.4668 \\
1.0166 \\
0.8659 \\
0.8636 \\
1.4897 \\
1.4815 \\
1.1162 \\
1.1217 \\
1.3239\end{array}$ & $\begin{array}{l}0.6069 \\
0.6052 \\
0.6051 \\
0.6031 \\
0.6018 \\
0.6014 \\
0.6014 \\
0.6037 \\
0.6058 \\
0.6044 \\
0.6026 \\
0.6017 \\
0.6032 \\
0.6042 \\
0.6020\end{array}$ & $\begin{array}{l}0.6069 \\
0.6053 \\
0.6052 \\
0.6032 \\
0.6020 \\
0.6016 \\
0.6016 \\
0.6038 \\
0.6059 \\
0.6044 \\
0.6028 \\
0.6019 \\
0.6033 \\
0.6043 \\
0.6021\end{array}$ \\
\hline
\end{tabular}

Table 19. Measured and calculated quantities for 0.55 beta ratio, elbow at 170, 111 at 150 , flange taps at position A. Pipe Diameter $=10.366 \mathrm{~cm}(4.081 \mathrm{in}), 3.8 \mathrm{\mu m}$ Orifice Diameter $=5.7142 \mathrm{~cm}(2.2497 \mathrm{in})$

\begin{tabular}{|c|c|c|c|c|c|c|c|c|}
\hline Run 10 & $\begin{array}{c}\text { Pressure } \\
\text { (MPa) }\end{array}$ & $\begin{array}{c}\text { Temperature } \\
\text { (K) }\end{array}$ & $\begin{array}{l}\text { Density } \\
\left(\mathrm{kg} / \mathrm{m}^{3}\right)\end{array}$ & $\begin{array}{l}\text { Dif Press } \\
\qquad(\mathrm{kPa})\end{array}$ & $\begin{array}{c}\text { Flow Rate } \\
(\mathrm{kg} / \mathrm{s})\end{array}$ & $\begin{array}{c}\text { Pipe Re No. } \\
\left(/ 10^{6}\right)\end{array}$ & C & $\mathrm{CY}_{2}$ \\
\hline $\begin{array}{l}061091-1 \\
061091-2 \\
061091-1 \\
061091-2 \\
061091-3 \\
061091-4 \\
071191-2 \\
071191-3 \\
071191-4 \\
071191-5 \\
071191-6 \\
071291-1 \\
071291-2 \\
071291-3 \\
071291-4 \\
071291-5 \\
071291-6 \\
071291-7 \\
071291-8 \\
071291-9 \\
071291-10\end{array}$ & $\begin{array}{l}3.9224 \\
3.9294 \\
3.8309 \\
3.8200 \\
3.9899 \\
4.0024 \\
4.0089 \\
3.8227 \\
3.8236 \\
4.0797 \\
4.0746 \\
3.9857 \\
3.9841 \\
3.8039 \\
3.8037 \\
3.9881 \\
3.9912 \\
3.8992 \\
3.8983 \\
3.8983 \\
3.9049\end{array}$ & $\begin{array}{l}285.10 \\
286.38 \\
284.46 \\
283.82 \\
286.07 \\
285.86 \\
283.68 \\
282.00 \\
282.06 \\
288.46 \\
287.84 \\
285.04 \\
285.12 \\
283.12 \\
282.90 \\
285.54 \\
285.96 \\
283.19 \\
282.99 \\
283.01 \\
283.48\end{array}$ & $\begin{array}{l}46.76 \\
46.61 \\
45.78 \\
45.76 \\
47.39 \\
47.58 \\
48.06 \\
46.12 \\
46.12 \\
48.02 \\
48.07 \\
47.53 \\
47.49 \\
45.69 \\
45.73 \\
47.46 \\
47.42 \\
46.83 \\
46.85 \\
46.85 \\
46.84\end{array}$ & $\begin{array}{r}12.857 \\
12.610 \\
19.608 \\
19.544 \\
6.201 \\
6.316 \\
6.166 \\
19.397 \\
19.271 \\
2.994 \\
3.009 \\
6.154 \\
6.151 \\
19.834 \\
19.568 \\
3.113 \\
3.130 \\
13.114 \\
13.096 \\
13.068 \\
13.062\end{array}$ & $\begin{array}{l}1.7774 \\
1.7624 \\
2.1724 \\
2.1676 \\
1.2483 \\
1.2634 \\
1.2575 \\
2.1770 \\
2.1640 \\
0.8764 \\
0.8791 \\
1.2460 \\
1.2464 \\
2.1835 \\
2.1696 \\
0.8889 \\
0.8904 \\
1.8009 \\
1.8008 \\
1.7942 \\
1.7917\end{array}$ & $\begin{array}{l}1.2135 \\
1.1994 \\
1.4872 \\
1.4864 \\
0.8495 \\
0.8602 \\
0.8606 \\
1.4995 \\
1.4903 \\
0.5924 \\
0.5951 \\
0.8501 \\
0.8503 \\
1.5001 \\
1.4914 \\
0.6057 \\
0.6061 \\
1.2356 \\
1.2362 \\
1.2316 \\
1.2284\end{array}$ & $\begin{array}{l}0.6020 \\
0.6036 \\
0.6019 \\
0.6017 \\
0.6049 \\
0.6054 \\
0.6068 \\
0.6042 \\
0.6026 \\
0.6073 \\
0.6073 \\
0.6052 \\
0.6058 \\
0.6021 \\
0.6021 \\
0.6075 \\
0.6072 \\
0.6035 \\
0.6037 \\
0.6022 \\
0.6015\end{array}$ & $\begin{array}{l}0.6023 \\
0.6040 \\
0.6025 \\
0.6023 \\
0.6050 \\
0.6056 \\
0.6070 \\
0.6049 \\
0.6032 \\
0.6073 \\
0.6074 \\
0.6054 \\
0.6060 \\
0.6027 \\
0.6027 \\
0.6076 \\
0.6073 \\
0.6039 \\
0.6041 \\
0.6026 \\
0.6019\end{array}$ \\
\hline
\end{tabular}

Table 20. Measured and calculated quantities for 0.55 beta ratio, elbow at 17D, 111 at 150 , flange taps at position $C$. Pipe Diameter $=10.366 \mathrm{~cm}(4.081 \mathrm{in}), 3.8 \mathrm{\mu m}$ Orifice Diameter $=5.7142 \mathrm{~cm}(2.2497 \mathrm{in})$

$\begin{array}{lcccccccc}\text { Run 10 } & \begin{array}{c}\text { Pressure } \\ \text { (MPa) }\end{array} & \begin{array}{c}\text { Temperature } \\ (\mathrm{K})\end{array} & \begin{array}{c}\text { Density } \\ \left(\mathrm{kg} / \mathrm{m}^{3}\right)\end{array} & \begin{array}{c}\text { Dif Press } \\ (\mathrm{kPa})\end{array} & \begin{array}{c}\text { Flow Rate } \\ (\mathrm{kg} / \mathrm{s})\end{array} & \begin{array}{c}\text { Pipe Re No. } \\ \left(/ 10^{6}\right)\end{array} & \mathrm{C} \\ 061091-1 & 3.9224 & 285.10 & 46.76 & 12.866 & 1.7774 & 1.2135 & 0.6018 & 0.6021 \\ 061091-2 & 3.9294 & 286.38 & 46.61 & 12.625 & 1.7624 & 1.1994 & 0.6033 & 0.6037 \\ 061091-1 & 3.8309 & 284.46 & 45.78 & 19.650 & 2.1724 & 1.4872 & 0.6013 & 0.6019 \\ 061091-2 & 3.8200 & 283.82 & 45.76 & 19.575 & 2.1676 & 1.4864 & 0.6012 & 0.6018 \\ 061091-3 & 3.9899 & 286.07 & 47.39 & 6.204 & 1.2483 & 0.8495 & 0.6047 & 0.6049 \\ 061091-4 & 4.0024 & 285.86 & 47.58 & 6.319 & 1.2634 & 0.8602 & 0.6053 & 0.6055 \\ 071191-2 & 4.0089 & 283.68 & 48.06 & 6.174 & 1.2575 & 0.8606 & 0.6064 & 0.6066 \\ 071191-3 & 3.8227 & 282.00 & 46.12 & 19.474 & 2.1770 & 1.4995 & 0.6030 & 0.6036 \\ 071191-4 & 3.8236 & 282.06 & 46.12 & 19.348 & 2.1640 & 1.4903 & 0.6014 & 0.6020 \\ 071191-5 & 4.0797 & 288.46 & 48.02 & 3.007 & 0.8764 & 0.5924 & 0.6059 & 0.6060 \\ 071191-6 & 4.0746 & 287.84 & 48.07 & 3.022 & 0.8791 & 0.5951 & 0.6060 & 0.6061 \\ 071291-1 & 3.9857 & 285.04 & 47.53 & 6.161 & 1.2460 & 0.8501 & 0.6049 & 0.6050 \\ 071291-2 & 3.9841 & 285.12 & 47.49 & 6.161 & 1.2464 & 0.8503 & 0.6053 & 0.6054 \\ 071291-3 & 3.8039 & 283.12 & 45.69 & 19.893 & 2.1835 & 1.5001 & 0.6012 & 0.6018 \\ 071291-4 & 3.8037 & 282.90 & 45.73 & 19.627 & 2.1696 & 1.4914 & 0.6012 & 0.6018 \\ 071291-5 & 3.9881 & 285.54 & 47.46 & 3.122 & 0.8889 & 0.6057 & 0.6067 & 0.6068 \\ 071291-6 & 3.9912 & 285.96 & 47.42 & 3.142 & 0.8904 & 0.6061 & 0.6061 & 0.6062 \\ 071291-7 & 3.8992 & 283.19 & 46.83 & 13.145 & 1.8009 & 1.2356 & 0.6028 & 0.6032 \\ 071291-8 & 3.8983 & 282.99 & 46.85 & 13.132 & 1.8008 & 1.2362 & 0.6029 & 0.6033 \\ 071291-9 & 3.8983 & 283.01 & 46.85 & 13.097 & 1.7942 & 1.2316 & 0.6015 & 0.6019 \\ 071291-10 & 3.9049 & 283.48 & 46.84 & 13.097 & 1.7917 & 1.2284 & 0.6007 & 0.6011\end{array}$


Table 21. Measured and calculated quantities for 0.55 beta ratio, elbow at 220, 111 at 150 , flange taps at position A.

Pipe Diameter $=10.366 \mathrm{~cm}(4.081 \mathrm{in}), 3.8 \mu \mathrm{m}$ Orifice Diameter $=5.7142 \mathrm{~cm}(2.2497 \mathrm{in})$

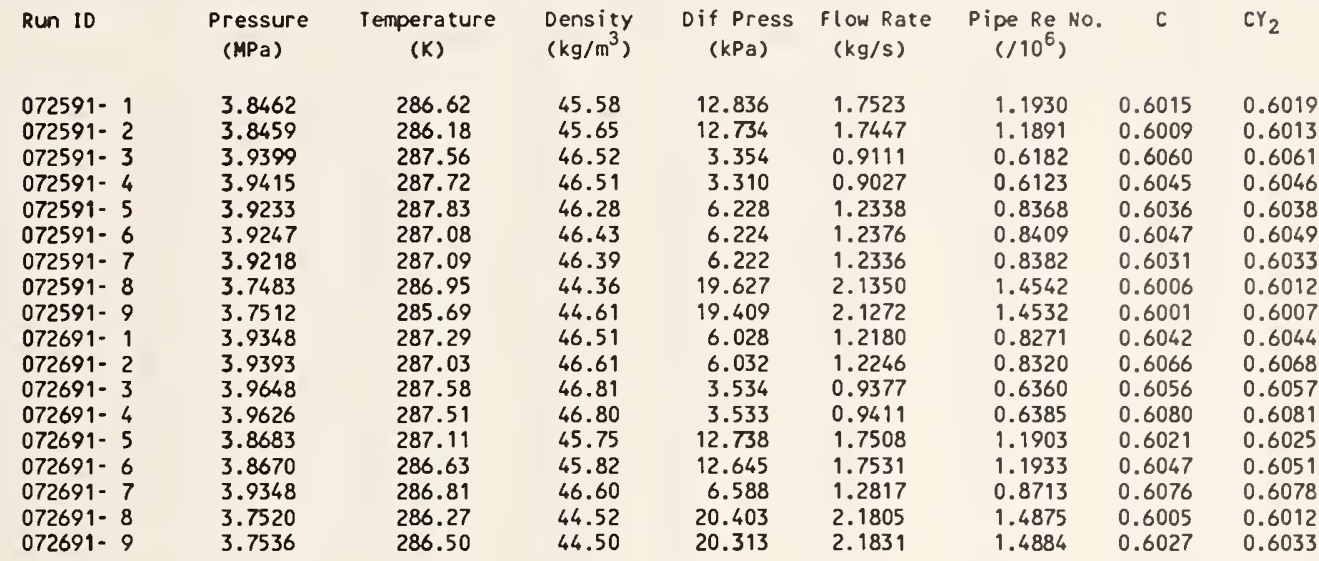

Table 22. Measured and calculated quantities for 0.55 beta ratio, elbow at 22D, IT1 at 150 , flange taps at position C.

Pipe 0iameter $=10.366 \mathrm{~cm}(4.081 \mathrm{in}), 3.8 \mu \mathrm{m}$ Orifice Diameter $=5.7142 \mathrm{~cm}(2.2497 \mathrm{in})$

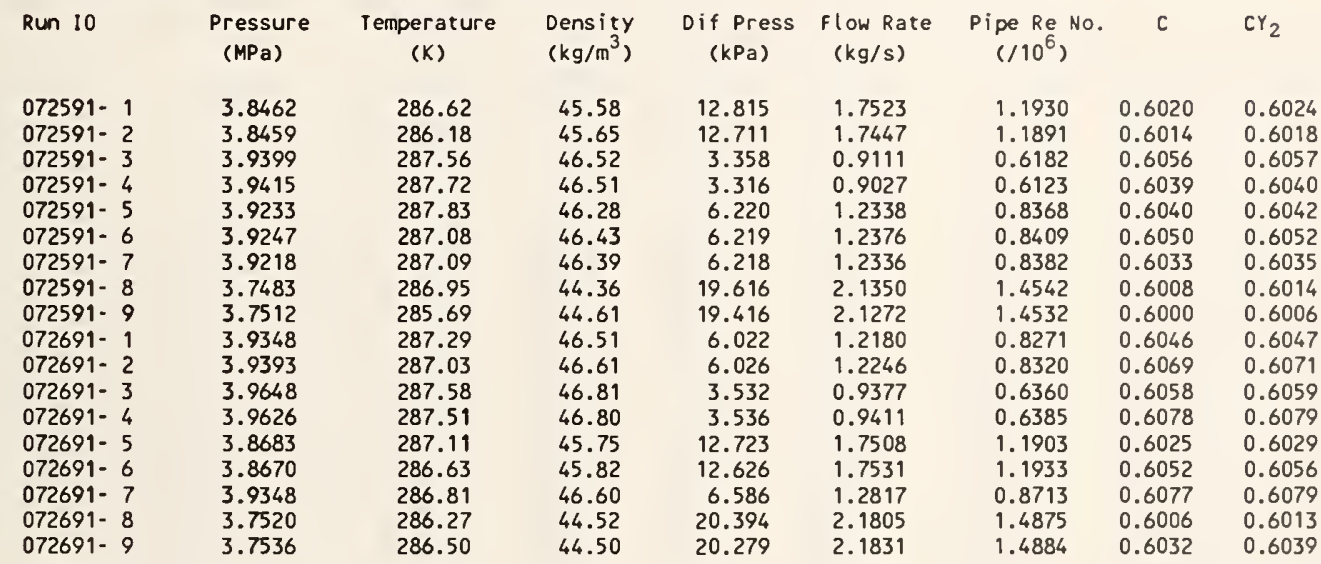

Table 23. Measured and calculated quantities for 0.55 beta ratio, elbow at 34D, ITI at 150, ftange taps at position A.

Pipe Oiameter $=10.366 \mathrm{~cm}(4.081 \mathrm{in}), 3.8 \mu \mathrm{m}$ Orifice Diameter $=5.7142 \mathrm{~cm}(2.2497 \mathrm{in})$

\begin{tabular}{|c|c|c|c|c|c|c|c|c|}
\hline Run 10 & $\begin{array}{c}\text { Pressure } \\
\text { (MPa) }\end{array}$ & $\begin{array}{c}\text { Temperature } \\
\text { (K) }\end{array}$ & $\begin{array}{l}\text { Density } \\
\left(\mathrm{kg} / \mathrm{m}^{3}\right)\end{array}$ & $\begin{array}{c}\text { Dif Press } \\
(\mathrm{kPa})\end{array}$ & $\begin{array}{c}\text { Flow Rate } \\
(\mathrm{kg} / \mathrm{s})\end{array}$ & $\begin{array}{l}\text { Pipe Re No. } \\
\left(/ 10^{6}\right)\end{array}$ & C & $\mathrm{Cr}_{2}$ \\
\hline $072991-1$ & 3.8220 & 287.48 & 45.14 & 13.035 & 1.7599 & 1.1960 & 0.6024 & 0.6028 \\
\hline $072991-2$ & 3.8188 & 286.74 & 45.23 & 13.039 & 1.7548 & 1.1948 & 0.6000 & 0.6004 \\
\hline $072991-3$ & 3.7234 & 286.94 & 44.06 & 20.167 & 2.1591 & 1.4711 & 0.6012 & 0.6018 \\
\hline $072991-4$ & 3.7159 & 285.38 & 44.24 & 19.767 & 2.1350 & 1.4603 & 0.5993 & 0.5999 \\
\hline $072991-5$ & 3.8884 & 287.13 & 45.99 & 6.930 & 1.2985 & 0.8826 & 0.6041 & 0.6044 \\
\hline $072991-6$ & 3.8874 & 287.30 & 45.95 & 6.990 & 1.3051 & 0.8867 & 0.6049 & 0.605 \\
\hline $072991-7$ & 3.9110 & 288.38 & 46.04 & 3.533 & 0.9290 & 0.6294 & 0.6051 & 0.6053 \\
\hline $072991-8$ & 3.9094 & 288.34 & 46.02 & 3.534 & 0.9297 & 0.6299 & 0.6056 & 0.6057 \\
\hline $072991-9$ & 3.8284 & 287.86 & 45.15 & 12.502 & 1.7214 & 1.1688 & 0.6016 & 0.602 \\
\hline $073091-1$ & 3.7438 & 286.11 & 44.45 & 20.492 & 2.1864 & 1.4923 & 0.6013 & 0.601 \\
\hline $073091-2$ & 3.7443 & 287.69 & 44.18 & 20.499 & 2.1815 & 1.4832 & 0.6016 & 0.602 \\
\hline $073091-3$ & 3.8469 & 287.06 & 45.51 & 13.145 & 1.7755 & 1.2075 & 0.6027 & 0.603 \\
\hline $073091-4$ & 3.8467 & 288.19 & 45.31 & 13.218 & 1.7803 & 1.2075 & 0.6040 & 0.604 \\
\hline $073091-5$ & 3.9275 & 288.26 & 46.25 & 6.145 & 1.2268 & 0.8312 & 0.6044 & 0.604 \\
\hline $073091-6$ & 3.9272 & 287.88 & 46.32 & 6.183 & 1.2340 & 0.8368 & 0.6057 & 0.605 \\
\hline $073091-7$ & 3.9482 & 288.42 & 46.47 & 3.182 & 0.8885 & 0.6016 & 0.6071 & 0.607 \\
\hline $073091-8$ & 3.9546 & 288.74 & 46.49 & 3.174 & 0.8873 & 0.6003 & 0.6070 & 0.607 \\
\hline $073091-9$ & 3.9536 & 288.44 & 46.53 & 3.183 & 0.8893 & 0.6021 & 0.6072 & 0.607 \\
\hline $073091-10$ & 3.9383 & 288.21 & 46.39 & 6.018 & 1.2171 & 0.8245 & 0.6050 & 0.605 \\
\hline $073091-11$ & 3.9334 & 288.08 & 46.35 & 6.013 & 1.2155 & 0.8238 & 0.6047 & 0.604 \\
\hline $073091-12$ & 3.8491 & 287.44 & 45.47 & 13.184 & 1.7762 & 1.2069 & 0.6024 & 0.602 \\
\hline $073091-13$ & 3.9488 & 288.45 & 46.47 & 3.433 & 0.9205 & 0.6232 & 0.6055 & 0.605 \\
\hline $073091-14$ & 3.9811 & 288.17 & 46.90 & 5.931 & 1.2140 & 0.8221 & 0.6046 & 0.604 \\
\hline
\end{tabular}


Table 24. Measured and calculated quantities for 0.55 beta ratio, elbow at 34D, IT1 at 150, flange taps at position C.

\begin{tabular}{|c|c|c|c|c|c|c|c|c|}
\hline Run ID & $\begin{array}{l}\text { Pressure } \\
\text { (MPa) }\end{array}$ & $\begin{array}{c}\text { Temperature } \\
(K)\end{array}$ & $\begin{array}{l}\text { Density } \\
\left(\mathrm{kg} / \mathrm{m}^{3}\right)\end{array}$ & $\begin{array}{l}\text { Dif Press } \\
\text { (KPa) }\end{array}$ & $\begin{array}{c}\text { Flow Rate } \\
(\mathrm{kg} / \mathrm{s})\end{array}$ & $\begin{array}{l}\text { Pipe Re No. } \\
\left(/ 10^{6}\right)\end{array}$ & C & $\mathrm{CY}_{2}$ \\
\hline $\begin{array}{l}072991-1 \\
072991-2 \\
072991-3 \\
072991-4 \\
072991-5 \\
072991-6 \\
072991-7 \\
072991-8 \\
072991-9 \\
073091-1 \\
073091-2 \\
073091-3 \\
073091-4 \\
073091-5 \\
073091-6 \\
073091-7 \\
073091-8 \\
073091-9 \\
073091-10 \\
073091-11 \\
073091-12 \\
073091-13 \\
073091-14\end{array}$ & $\begin{array}{l}3.8220 \\
3.8188 \\
3.7234 \\
3.7159 \\
3.8884 \\
3.8874 \\
3.9110 \\
3.9094 \\
3.8284 \\
3.7438 \\
3.7443 \\
3.8469 \\
3.8467 \\
3.9275 \\
3.9272 \\
3.9482 \\
3.9546 \\
3.9536 \\
3.9383 \\
3.9334 \\
3.8491 \\
3.9488 \\
3.9811\end{array}$ & $\begin{array}{l}287.48 \\
286.74 \\
286.94 \\
285.38 \\
287.13 \\
287.30 \\
288.38 \\
288.34 \\
287.86 \\
286.11 \\
287.69 \\
287.06 \\
288.19 \\
288.26 \\
287.88 \\
288.42 \\
288.74 \\
288.44 \\
288.21 \\
288.08 \\
287.44 \\
288.45 \\
288.17\end{array}$ & $\begin{array}{l}45.14 \\
45.23 \\
44.06 \\
44.24 \\
45.99 \\
45.95 \\
46.04 \\
46.02 \\
45.15 \\
44.45 \\
44.18 \\
45.51 \\
45.31 \\
46.25 \\
46.32 \\
46.47 \\
46.49 \\
46.53 \\
46.39 \\
46.35 \\
45.47 \\
46.47 \\
46.90\end{array}$ & $\begin{array}{r}13.011 \\
13.015 \\
20.162 \\
19.755 \\
6.912 \\
6.973 \\
3.522 \\
3.524 \\
12.490 \\
20.486 \\
20.482 \\
13.144 \\
13.232 \\
6.146 \\
6.186 \\
3.194 \\
3.183 \\
3.189 \\
6.020 \\
6.018 \\
13.185 \\
3.439 \\
5.925\end{array}$ & $\begin{array}{l}1.7599 \\
1.7548 \\
2.1591 \\
2.1350 \\
1.2985 \\
1.3051 \\
0.9290 \\
0.9297 \\
1.7214 \\
2.1864 \\
2.1815 \\
1.7755 \\
1.7803 \\
1.2268 \\
1.2340 \\
0.8885 \\
0.8873 \\
0.8893 \\
1.2171 \\
1.2155 \\
1.7762 \\
0.9205 \\
1.2140\end{array}$ & $\begin{array}{l}1.1960 \\
1.1948 \\
1.4711 \\
1.4603 \\
0.8826 \\
0.8867 \\
0.6294 \\
0.6299 \\
1.1688 \\
1.4923 \\
1.4832 \\
1.2075 \\
1.2075 \\
0.8312 \\
0.8368 \\
0.6016 \\
0.6003 \\
0.6021 \\
0.8245 \\
0.8238 \\
1.2069 \\
0.6232 \\
0.8221\end{array}$ & $\begin{array}{l}0.6030 \\
0.6005 \\
0.6012 \\
0.5994 \\
0.6050 \\
0.6056 \\
0.6061 \\
0.6064 \\
0.6019 \\
0.6014 \\
0.6018 \\
0.6028 \\
0.6037 \\
0.6044 \\
0.6055 \\
0.6060 \\
0.6061 \\
0.6066 \\
0.6049 \\
0.6044 \\
0.6023 \\
0.6049 \\
0.6049\end{array}$ & $\begin{array}{l}0.6034 \\
0.6009 \\
0.6019 \\
0.6001 \\
0.6052 \\
0.6058 \\
0.6062 \\
0.6065 \\
0.6023 \\
0.6020 \\
0.6025 \\
0.6032 \\
0.6041 \\
0.6046 \\
0.6057 \\
0.6061 \\
0.6062 \\
0.6067 \\
0.6051 \\
0.6046 \\
0.6027 \\
0.6050 \\
0.6051\end{array}$ \\
\hline
\end{tabular}

Table 25. Measured and calculated quantities for 0.67 beta ratio, elbow at 170, IT1 at 15D, flange taps at position A. Pipe Diameter $=10.366 \mathrm{~cm}(4.081 \mathrm{in}), 3.8 \mu \mathrm{m}$ Orifice Diameter $=6.9840 \mathrm{~cm}(2.7496 \mathrm{in})$

\begin{tabular}{|c|c|c|c|c|c|c|c|c|}
\hline Run 10 & $\begin{array}{c}\text { Pressure } \\
\text { (MPa) }\end{array}$ & $\begin{array}{c}\text { Temperature } \\
\text { (K) }\end{array}$ & $\begin{array}{l}\text { Dens ity } \\
\left(\mathrm{kg} / \mathrm{m}^{3}\right)\end{array}$ & $\begin{array}{c}\text { Dif Press } \\
\text { (KPa) }\end{array}$ & $\begin{array}{c}\text { Flow Rate } \\
(\mathrm{kg} / \mathrm{s})\end{array}$ & $\begin{array}{c}\text { Pipe Re No. } \\
\left(/ 10^{6}\right)\end{array}$ & C & $\mathrm{Cr}_{2}$ \\
\hline $\begin{array}{l}061091-1 \\
061091-2 \\
061091-3 \\
061091-4 \\
061091-5 \\
061091-6 \\
061091-7 \\
061091-8 \\
071291-1 \\
071291-2 \\
071291-3 \\
071291-4 \\
071291-5 \\
071291-6 \\
071291-7 \\
071291-9 \\
071291-10 \\
071291-11\end{array}$ & $\begin{array}{l}3.8994 \\
3.9053 \\
3.9588 \\
3.9579 \\
3.8218 \\
3.8203 \\
3.9842 \\
3.9832 \\
3.9400 \\
3.9390 \\
3.8007 \\
3.8001 \\
3.8696 \\
3.8698 \\
3.9698 \\
3.9628 \\
3.8094 \\
3.8123\end{array}$ & $\begin{array}{l}285.73 \\
285.46 \\
285.79 \\
285.33 \\
284.81 \\
284.46 \\
285.64 \\
285.49 \\
283.83 \\
283.81 \\
283.44 \\
283.33 \\
283.80 \\
284.01 \\
284.19 \\
285.16 \\
283.52 \\
283.87\end{array}$ & $\begin{array}{l}46.37 \\
46.49 \\
47.07 \\
47.14 \\
45.61 \\
45.65 \\
47.40 \\
47.41 \\
47.20 \\
47.19 \\
45.59 \\
45.60 \\
46.36 \\
46.32 \\
47.49 \\
47.23 \\
45.68 \\
45.66\end{array}$ & $\begin{array}{l}5.725 \\
5.662 \\
4.032 \\
4.040 \\
7.698 \\
7.583 \\
2.556 \\
2.577 \\
4.019 \\
4.006 \\
7.975 \\
7.844 \\
6.037 \\
6.036 \\
2.539 \\
2.606 \\
7.592 \\
7.473\end{array}$ & $\begin{array}{l}1.8954 \\
1.8841 \\
1.6009 \\
1.6048 \\
2.1710 \\
2.1594 \\
1.2790 \\
1.2876 \\
1.6024 \\
1.5998 \\
2.2124 \\
2.1863 \\
1.9423 \\
1.9392 \\
1.2808 \\
1.2962 \\
2.1613 \\
2.1418\end{array}$ & $\begin{array}{l}1.2924 \\
1.2855 \\
1.0907 \\
1.0946 \\
1.4851 \\
1.4784 \\
0.8714 \\
0.8776 \\
1.0972 \\
1.0954 \\
1.5189 \\
1.5013 \\
1.3311 \\
1.3283 \\
0.8759 \\
0.8844 \\
1.4833 \\
1.4686\end{array}$ & $\begin{array}{l}0.6050 \\
0.6040 \\
0.6044 \\
0.6049 \\
0.6026 \\
0.6036 \\
0.6044 \\
0.6059 \\
0.6052 \\
0.6052 \\
0.6034 \\
0.6012 \\
0.6039 \\
0.6032 \\
0.6067 \\
0.6078 \\
0.6036 \\
0.6030\end{array}$ & $\begin{array}{l}0.6052 \\
0.6041 \\
0.6045 \\
0.6050 \\
0.6028 \\
0.6038 \\
0.6045 \\
0.6060 \\
0.6053 \\
0.6053 \\
0.6037 \\
0.6014 \\
0.6040 \\
0.6033 \\
0.6068 \\
0.6078 \\
0.6038 \\
0.6032\end{array}$ \\
\hline
\end{tabular}

Table 26. Measured and calculated quantities for 0.67 beta ratio, elbow at 170,111 at 150 , flange taps at position $\mathrm{C}$.

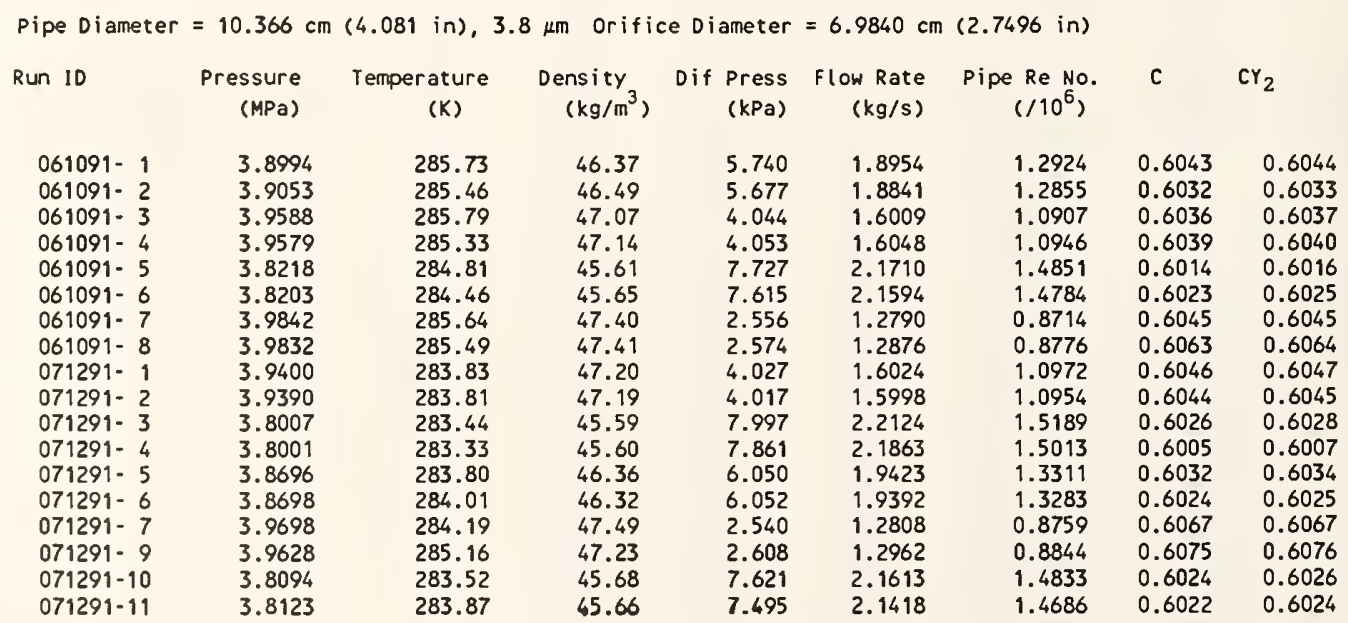


Table 27. Measured and calculated quantities for 0.67 beta ratio, elbow at 220, 111 at $150, f l a n g e$ taps at position A. Pipe Diameter $=10.366 \mathrm{~cm}(4.081 \mathrm{in}), 3.8 \mu \mathrm{m}$ Orifice Diameter $=6.9840 \mathrm{~cm}(2.7496 \mathrm{in})$

\begin{tabular}{|c|c|c|c|c|c|c|c|c|}
\hline Run 10 & $\begin{array}{l}\text { Pressure } \\
\text { (MPa) }\end{array}$ & $\begin{array}{c}\text { Temperature } \\
\text { (K) }\end{array}$ & $\begin{array}{l}\text { Density } \\
\left(\mathrm{kg} / \mathrm{m}^{3}\right)\end{array}$ & $\begin{array}{c}\text { Dif Press } \\
\text { (KPa) }\end{array}$ & $\begin{array}{c}\text { Flow Rate } \\
(\mathrm{kg} / \mathrm{s})\end{array}$ & $\begin{array}{c}\text { Pipe Re No. } \\
\left(/ 10^{6}\right)\end{array}$ & C & $\mathrm{CY}_{2}$ \\
\hline $\begin{array}{l}072591-1 \\
072591-2 \\
072591-3 \\
072591-4 \\
072591-5 \\
072591-6 \\
072591-7 \\
072591-8 \\
072591-9 \\
072691-1 \\
072691-2 \\
072691-3 \\
072691-4 \\
072691-5 \\
072691-6 \\
072691-7 \\
072691-8 \\
072691-9\end{array}$ & $\begin{array}{l}3.8877 \\
3.9216 \\
3.7507 \\
3.7488 \\
3.9178 \\
3.9184 \\
3.8245 \\
3.8467 \\
3.8854 \\
3.7971 \\
3.8007 \\
3.7223 \\
3.7263 \\
3.7288 \\
3.8553 \\
3.8560 \\
3.9193 \\
3.9206\end{array}$ & $\begin{array}{l}286.76 \\
286.48 \\
287.27 \\
286.73 \\
286.79 \\
287.49 \\
286.78 \\
286.31 \\
286.58 \\
286.34 \\
286.86 \\
286.81 \\
286.14 \\
287.16 \\
287.13 \\
286.65 \\
287.34 \\
287.21\end{array}$ & $\begin{array}{l}46.05 \\
46.50 \\
44.33 \\
44.40 \\
46.40 \\
46.28 \\
45.29 \\
45.64 \\
46.05 \\
45.04 \\
44.99 \\
44.07 \\
44.23 \\
44.09 \\
45.59 \\
45.69 \\
46.32 \\
46.36\end{array}$ & $\begin{array}{l}4.146 \\
4.156 \\
7.823 \\
7.775 \\
2.593 \\
2.618 \\
6.028 \\
6.012 \\
4.218 \\
5.967 \\
5.932 \\
8.082 \\
8.031 \\
8.128 \\
4.217 \\
4.230 \\
2.511 \\
2.517\end{array}$ & $\begin{array}{l}1.6035 \\
1.6197 \\
2.1533 \\
2.1530 \\
1.2762 \\
1.2817 \\
1.9124 \\
1.9219 \\
1.6211 \\
1.8980 \\
1.8889 \\
2.1803 \\
2.1732 \\
2.1845 \\
1.6101 \\
1.6119 \\
1.2561 \\
1.2565\end{array}$ & $\begin{array}{l}1.0908 \\
1.1021 \\
1.4654 \\
1.4672 \\
0.8678 \\
0.8701 \\
1.3019 \\
1.3095 \\
1.1033 \\
1.2938 \\
1.2860 \\
1.4859 \\
1.4834 \\
1.4874 \\
1.0948 \\
1.0972 \\
0.8529 \\
0.8535\end{array}$ & $\begin{array}{l}0.6036 \\
0.6060 \\
0.6013 \\
0.6026 \\
0.6052 \\
0.6057 \\
0.6019 \\
0.6035 \\
0.6050 \\
0.6021 \\
0.6013 \\
0.6008 \\
0.5996 \\
0.6001 \\
0.6039 \\
0.6031 \\
0.6058 \\
0.6050\end{array}$ & $\begin{array}{l}0.6037 \\
0.6061 \\
0.6015 \\
0.6028 \\
0.6053 \\
0.6057 \\
0.6021 \\
0.6036 \\
0.6051 \\
0.6023 \\
0.6015 \\
0.6010 \\
0.5998 \\
0.6003 \\
0.6040 \\
0.6032 \\
0.6059 \\
0.6051\end{array}$ \\
\hline
\end{tabular}

Table 28. Measured and calculated quantities for 0.67 beta ratio, elbow at 220, 111 at 150 , flange taps at position C.

Pipe Diameter $=10.366 \mathrm{~cm}(4.081 \mathrm{in}), 3.8 \mu \mathrm{m}$ Orifice Diameter $=6.9840 \mathrm{~cm}(2.7496 \mathrm{in})$

\begin{tabular}{|c|c|c|c|c|c|c|c|c|}
\hline Run 10 & $\begin{array}{l}\text { Pressure } \\
\text { (MPa) }\end{array}$ & $\begin{array}{c}\text { Temperature } \\
\text { (K) }\end{array}$ & $\begin{array}{l}\text { Density } \\
\left(\mathrm{kg} / \mathrm{m}^{3}\right)\end{array}$ & $\begin{array}{c}\text { Dif Press } \\
\text { (XPa) }\end{array}$ & $\begin{array}{c}\text { F low Rate } \\
(\mathrm{kg} / \mathrm{s})\end{array}$ & $\begin{array}{c}\text { Pipe Re No. } \\
\left(/ 10^{6}\right)\end{array}$ & C & $\mathrm{CY}_{2}$ \\
\hline $\begin{array}{l}072591-1 \\
072591-2 \\
072591-3 \\
072591-4 \\
072591-5 \\
072591-6 \\
072591-7 \\
072591-8 \\
072591-9 \\
072691-1 \\
072691-2 \\
072691-3 \\
072691-4 \\
072691-5 \\
072691-6 \\
072691-7 \\
072691-8 \\
072691-9\end{array}$ & $\begin{array}{l}3.8877 \\
3.9216 \\
3.7507 \\
3.7488 \\
3.9178 \\
3.9184 \\
3.8245 \\
3.8467 \\
3.8854 \\
3.7971 \\
3.8007 \\
3.7223 \\
3.7263 \\
3.7288 \\
3.8553 \\
3.8560 \\
3.9193 \\
3.9206\end{array}$ & $\begin{array}{l}286.76 \\
286.48 \\
287.27 \\
286.73 \\
286.79 \\
287.49 \\
286.78 \\
286.31 \\
286.58 \\
286.34 \\
286.86 \\
286.81 \\
286.14 \\
287.16 \\
287.13 \\
286.65 \\
287.34 \\
287.21\end{array}$ & $\begin{array}{l}46.05 \\
46.50 \\
44.33 \\
44.40 \\
46.40 \\
46.28 \\
45.29 \\
45.64 \\
46.05 \\
45.04 \\
44.99 \\
44.07 \\
44.23 \\
44.09 \\
45.59 \\
45.69 \\
46.32 \\
46.36\end{array}$ & $\begin{array}{l}4.146 \\
4.154 \\
7.795 \\
7.736 \\
2.582 \\
2.609 \\
6.010 \\
6.001 \\
4.215 \\
5.949 \\
5.922 \\
8.054 \\
8.000 \\
8.098 \\
4.214 \\
4.224 \\
2.512 \\
2.513\end{array}$ & $\begin{array}{l}1.6035 \\
1.6197 \\
2.1533 \\
2.1530 \\
1.2762 \\
1.2817 \\
1.9124 \\
1.9219 \\
1.6211 \\
1.8980 \\
1.8889 \\
2.1803 \\
2.1732 \\
2.1845 \\
1.6101 \\
1.6119 \\
1.2561 \\
1.2565\end{array}$ & $\begin{array}{l}1.0908 \\
1.1021 \\
1.4654 \\
1.4672 \\
0.8678 \\
0.8701 \\
1.3019 \\
1.3095 \\
1.1033 \\
1.2938 \\
1.2860 \\
1.4859 \\
1.4834 \\
1.4874 \\
1.0948 \\
1.0972 \\
0.8529 \\
0.8535\end{array}$ & $\begin{array}{l}0.6037 \\
0.6062 \\
0.6024 \\
0.6041 \\
0.6064 \\
0.6067 \\
0.6028 \\
0.6040 \\
0.6052 \\
0.6030 \\
0.6018 \\
0.6018 \\
0.6008 \\
0.6012 \\
0.6042 \\
0.6035 \\
0.6057 \\
0.6055\end{array}$ & $\begin{array}{l}0.6038 \\
0.6063 \\
0.6026 \\
0.6043 \\
0.6065 \\
0.6068 \\
0.6030 \\
0.6042 \\
0.6053 \\
0.6032 \\
0.6020 \\
0.6020 \\
0.6010 \\
0.6014 \\
0.6043 \\
0.6036 \\
0.6058 \\
0.6056\end{array}$ \\
\hline
\end{tabular}

Table 29. Measured and calculated quantities for 0.67 beta ratio, elbow at 340 , IT1 at 150 , flange taps at position A.

Pipe Diameter $=10.366 \mathrm{~cm}(4.081 \mathrm{in}), 3.8 \mu \mathrm{m}$ Orifice Diameter $=6.9840 \mathrm{~cm}(2.7496 \mathrm{in})$

\begin{tabular}{|c|c|c|c|c|c|c|c|c|}
\hline Run ID & $\begin{array}{c}\text { Pressure } \\
\text { (MPa) }\end{array}$ & $\begin{array}{c}\text { Temperature } \\
\text { (K) }\end{array}$ & $\begin{array}{l}\text { Density } \\
\left(\mathrm{kg} / \mathrm{m}^{3}\right)\end{array}$ & $\begin{array}{c}\text { Dif Press } \\
\text { (KPa) }\end{array}$ & $\begin{array}{c}\text { Flow Rate } \\
(\mathrm{kg} / \mathrm{s})\end{array}$ & $\begin{array}{c}\text { Pipe Re No. } \\
\left(/ 10^{6}\right)\end{array}$ & C & $\mathrm{CY}_{2}$ \\
\hline $072991 \cdot 1$ & 3.7765 & 287.06 & 44.67 & 6.360 & 1.9522 & 1.3289 & 0.6023 & 0.602 \\
\hline $072991-2$ & 3.7763 & 287.34 & 44.62 & 6.353 & 1.9478 & 1.3249 & 0.6016 & 0.60 \\
\hline $072991-3$ & 3.7165 & 287.12 & 43.95 & 8.071 & 2.1792 & 1.4842 & 0.6017 & 0.60 \\
\hline $072991 \cdot 4$ & 3.7173 & 286.97 & 43.98 & 8.034 & 2.1743 & 1.4814 & 0.6015 & 0.60 \\
\hline $072991-5$ & 3.8602 & 287.31 & 45.62 & 4.280 & 1.6230 & 1.1030 & 0.6041 & 0.60 \\
\hline $072991-6$ & 3.8613 & 287.53 & 45.60 & 4.311 & 1.6217 & 1.1015 & 0.6016 & 0.60 \\
\hline $072991 \cdot 7$ & 3.8933 & 287.77 & 45.93 & 2.566 & 1.2620 & 0.8563 & 0.6047 & 0.60 \\
\hline $072991-8$ & 3.8968 & 287.89 & 45.95 & 2.581 & 1.2648 & 0.8580 & 0.6041 & 0.60 \\
\hline $073091-1$ & 3.9310 & 287.29 & 46.47 & 4.044 & 1.5937 & 1.0822 & 0.6047 & 0.60 \\
\hline $073091 \cdot 2$ & 3.9308 & 287.43 & 46.44 & 4.040 & 1.5896 & 1.0791 & 0.6036 & 0.60 \\
\hline $073091-3$ & 3.9799 & 288.01 & 46.91 & 2.503 & 1.2637 & 0.8561 & 0.6066 & 0.60 \\
\hline $073091-4$ & 3.9781 & 287.69 & 46.95 & 2.504 & 1.2667 & 0.8588 & 0.6077 & 0.60 \\
\hline $073091-5$ & 3.7873 & 287.48 & 44.73 & 7.566 & 2.1298 & 1.4480 & 0.6020 & 0.60 \\
\hline $073091-6$ & 3.7874 & 286.74 & 44.86 & 7.491 & 2.1272 & 1.4489 & 0.6035 & 0.603 \\
\hline $073091-7$ & 3.8313 & 287.76 & 45.20 & 6.149 & 1.9317 & 1.3118 & 0.6025 & 0.602 \\
\hline $073091-8$ & 3.8299 & 286.82 & 45.35 & 6.134 & 1.9344 & 1.3167 & 0.6032 & 0.603 \\
\hline
\end{tabular}


Table 30. Measured and calculated quantities for 0.67 beta ratio, elbow at 340,111 at $150, f l a n g e$ taps at position $\mathrm{C}$. Pipe oiameter $=10.366 \mathrm{~cm}(4.081 \mathrm{in}), 3.8 \mu \mathrm{m}$ Orifice Diameter $=6.9840 \mathrm{~cm}(2.7496 \mathrm{in})$

\begin{tabular}{|c|c|c|c|c|c|c|c|c|}
\hline Run ID & $\begin{array}{l}\text { Pressure } \\
\text { (MPa) }\end{array}$ & $\begin{array}{c}\text { Temperature } \\
(\mathrm{K})\end{array}$ & $\begin{array}{l}\text { Density } \\
\left(\mathrm{kg} / \mathrm{m}^{3}\right)\end{array}$ & $\begin{array}{c}\text { Dif Press } \\
\text { (kPa) }\end{array}$ & $\begin{array}{c}\text { Flow Rate } \\
(\mathrm{kg} / \mathrm{s})\end{array}$ & $\begin{array}{l}\text { Pipe Re No. } \\
\left(/ 10^{6}\right)\end{array}$ & C & $\mathrm{CY}_{2}$ \\
\hline $\begin{array}{l}072991-1 \\
072991-2 \\
072991-3 \\
072991-4 \\
072991-5 \\
072991-6 \\
072991-7 \\
072991-8 \\
073091-1 \\
073091-2 \\
073091-3 \\
073091-4 \\
073091-5 \\
073091-6 \\
073091-7 \\
073091-8\end{array}$ & $\begin{array}{l}3.7765 \\
3.7763 \\
3.7165 \\
3.7173 \\
3.8602 \\
3.8613 \\
3.8933 \\
3.8968 \\
3.9310 \\
3.9308 \\
3.9799 \\
3.9781 \\
3.7873 \\
3.7874 \\
3.8313 \\
3.8299\end{array}$ & $\begin{array}{l}287.06 \\
287.34 \\
287.12 \\
286.97 \\
287.31 \\
287.53 \\
287.77 \\
287.89 \\
287.29 \\
287.43 \\
288.01 \\
287.69 \\
287.48 \\
286.74 \\
287.76 \\
286.82\end{array}$ & $\begin{array}{l}44.67 \\
44.62 \\
43.95 \\
43.98 \\
45.62 \\
45.60 \\
45.93 \\
45.95 \\
46.47 \\
46.44 \\
46.91 \\
46.95 \\
44.73 \\
44.86 \\
45.20 \\
45.35\end{array}$ & $\begin{array}{l}6.363 \\
6.350 \\
8.060 \\
8.019 \\
4.274 \\
4.301 \\
2.555 \\
2.577 \\
4.052 \\
4.046 \\
2.502 \\
2.501 \\
7.559 \\
7.484 \\
6.151 \\
6.137\end{array}$ & $\begin{array}{l}1.9522 \\
1.9478 \\
2.1792 \\
2.1743 \\
1.6230 \\
1.6217 \\
1.2620 \\
1.2648 \\
1.5937 \\
1.5896 \\
1.2637 \\
1.2667 \\
2.1298 \\
2.1272 \\
1.9317 \\
1.9344\end{array}$ & $\begin{array}{l}1.3289 \\
1.3249 \\
1.4842 \\
1.4814 \\
1.1030 \\
1.1015 \\
0.8563 \\
0.8580 \\
1.0822 \\
1.0791 \\
0.8561 \\
0.8588 \\
1.4480 \\
1.4489 \\
1.3118 \\
1.3167\end{array}$ & $\begin{array}{l}0.6022 \\
0.6018 \\
0.6021 \\
0.6020 \\
0.6045 \\
0.6023 \\
0.6060 \\
0.6046 \\
0.6041 \\
0.6031 \\
0.6067 \\
0.6080 \\
0.6023 \\
0.6038 \\
0.6024 \\
0.6031\end{array}$ & $\begin{array}{l}0.6024 \\
0.6020 \\
0.6023 \\
0.6023 \\
0.6046 \\
0.6024 \\
0.6060 \\
0.6046 \\
0.6042 \\
0.6032 \\
0.6067 \\
0.6081 \\
0.6025 \\
0.6040 \\
0.6026 \\
0.6032\end{array}$ \\
\hline
\end{tabular}

Table 31. Measured and calculated quantities for 0.55 beta ratio, elbow at 170, 1T1 at 130 , flange taps at position A. Pipe Diameter $=10.366 \mathrm{~cm}(4.081 \mathrm{in}), 3.8 \mu \mathrm{m}$ Orifice Diameter $=5.7142 \mathrm{~cm}(2.2497 \mathrm{in})$

\begin{tabular}{|c|c|c|c|c|c|c|c|c|}
\hline Run ID & $\begin{array}{l}\text { Pressure } \\
\text { (MPa) }\end{array}$ & $\begin{array}{c}\text { Temperature } \\
(\mathrm{K})\end{array}$ & $\begin{array}{l}\text { Density } \\
\left(\mathrm{kg} / \mathrm{m}^{3}\right)\end{array}$ & $\begin{array}{l}\text { Dif Press } \\
\text { (KPa) }\end{array}$ & $\begin{array}{c}\text { Flow Rate } \\
(\mathrm{kg} / \mathrm{s})\end{array}$ & $\begin{array}{c}\text { Pipe Re No. } \\
\left(/ 10^{6}\right)\end{array}$ & c & $\mathrm{CY}_{2}$ \\
\hline $071691-1$ & 3.7838 & 282.86 & 45.49 & 19.550 & 2.1599 & 1.4852 & 0.6012 & 0.6018 \\
\hline $071691-2$ & 3.7848 & 283.51 & 45.39 & 19.359 & 2. 1537 & 1.4786 & 0.6031 & 0.6037 \\
\hline $071691-3$ & 3.9499 & 285.86 & 46.95 & 5.997 & 1.2210 & 0.8318 & 0.6045 & 0.6046 \\
\hline $071691-4$ & 3.9501 & 285.03 & 47.10 & 5.939 & 1.2196 & 0.8325 & 0.6058 & 0.6059 \\
\hline $071691-5$ & 3.8711 & 284.31 & 46.29 & 13.623 & 1.8216 & 1.2469 & 0.6024 & 0.6028 \\
\hline $071691 \cdot 6$ & 3.8695 & 283.91 & 46.34 & 13.499 & 1.8203 & 1.2472 & 0.6044 & 0.6048 \\
\hline $071691-7$ & 4.0330 & 291.56 & 46.91 & 2.892 & 0.8517 & 0.5717 & 0.6074 & 0.6075 \\
\hline $071691-8$ & 4.0237 & 292.47 & 46.64 & 2.916 & 0.8529 & 0.5714 & 0.6075 & 0.6076 \\
\hline $071791-1$ & 3.8811 & 275.77 & 48.01 & 12.728 & 1.7942 & 1.2543 & 0.6029 & 0.6033 \\
\hline $071791-2$ & 3.8811 & 273.04 & 48.55 & 12.573 & 1.7943 & 1.2630 & 0.6033 & 0.6037 \\
\hline $071791-3$ & 3.9679 & 273.11 & 49.63 & 5.712 & 1.2254 & 0.8614 & 0.6048 & 0.6050 \\
\hline $071791-4$ & 3.9706 & 273.04 & 49.67 & 5.738 & 1.2282 & 0.8635 & 0.6046 & 0.6038 \\
\hline $071991-1$ & 3.7712 & 285.76 & 44.83 & 19.723 & 2.1497 & 1.4680 & 0.6000 & 0.6007 \\
\hline $071991-2$ & 3.7650 & 285.47 & 44.81 & 19.518 & 2.1321 & 1.4571 & 0.5984 & 0.5990 \\
\hline $071991-3$ & 3.9233 & 287.73 & 46.29 & 3.075 & 0.8693 & 0.5897 & 0.6054 & 0.6055 \\
\hline
\end{tabular}

Table 32. Measured and calculated quantities for 0.55 beta ratio, elbow at $170,1 T 1$ at 130 , flange taps at position $\mathrm{C}$.

Pipe Diameter $=10.366 \mathrm{~cm}(4.081 \mathrm{in}), 3.8 \mu \mathrm{m}$ Orifice Diameter $=5.7142 \mathrm{~cm}(2.2497 \mathrm{in})$

\begin{tabular}{|c|c|c|c|c|c|c|c|c|}
\hline Run ID & $\begin{array}{c}\text { Pressure } \\
\text { (MPa) }\end{array}$ & $\begin{array}{c}\text { Temperature } \\
(\mathrm{K})\end{array}$ & $\begin{array}{l}\text { Density } \\
\left(\mathrm{kg} / \mathrm{m}^{3}\right)\end{array}$ & $\begin{array}{c}\text { Dif Press } \\
\text { (kPa) }\end{array}$ & $\begin{array}{c}\text { Flow Rate } \\
(\mathrm{kg} / \mathrm{s})\end{array}$ & $\begin{array}{c}\text { Pipe Re No. } \\
\left(/ 10^{6}\right)\end{array}$ & C & $\mathrm{CY}_{2}$ \\
\hline $071691-1$ & 3.7838 & 282.86 & 45.49 & 19.565 & 2.1599 & 1.4852 & 0.6010 & 0.6016 \\
\hline $071691-2$ & 3.7848 & 283.51 & 45.39 & 19.364 & 2.1537 & 1.4786 & 0.6030 & 0.6036 \\
\hline $071691-3$ & 3.9499 & 285.86 & 46.95 & 5.998 & 1.2210 & 0.8318 & 0.6044 & 0.6046 \\
\hline $071691 \cdot 4$ & 3.9501 & 285.03 & 47.10 & 5.942 & 1.2196 & 0.8325 & 0.6056 & 0.6058 \\
\hline $071691-5$ & 3.8711 & 284.31 & 46.29 & 13.627 & 1.8216 & 1.2469 & 0.6023 & 0.6027 \\
\hline $071691-6$ & 3.8695 & 283.91 & 46.34 & 13.514 & 1.8203 & 1.2472 & 0.6040 & 0.6044 \\
\hline $071691 \cdot 7$ & 4.0330 & 291.56 & 46.91 & 2.893 & 0.8517 & 0.5717 & 0.6073 & 0.6074 \\
\hline $071691-8$ & 4.0237 & 292.47 & 46.64 & 2.914 & 0.8529 & 0.5714 & 0.6077 & 0.6078 \\
\hline $071791-1$ & 3.8811 & 275.77 & 48.01 & 12.724 & 1.7942 & 1.2543 & 0.6030 & 0.6034 \\
\hline $071791-2$ & 3.8811 & 273.04 & 48.55 & 12.587 & 1.7943 & 1.2630 & 0.6030 & 0.6034 \\
\hline $071791-3$ & 3.9679 & 273.11 & 49.63 & 5.711 & 1.2254 & 0.8614 & 0.6049 & 0.6051 \\
\hline $071791-4$ & 3.9706 & 273.04 & 49.67 & 5.737 & 1.2282 & 0.8635 & 0.6046 & 0.6048 \\
\hline $071991-1$ & 3.7712 & 285.76 & 44.83 & 19.739 & 2.1497 & 1.4680 & 0.5998 & 0.6004 \\
\hline $071991-2$ & 3.7650 & 285.47 & 44.81 & 19.530 & 2.1321 & 1.4571 & 0.5983 & 0.5989 \\
\hline $071991-3$ & 3.9233 & 287.73 & 46.29 & 3.086 & 0.8693 & 0.5897 & 0.6044 & 0.6045 \\
\hline
\end{tabular}


Table 33. Measured and calculated quantities for 0.55 beta ratio, elbow at 17D, IT1 at 110 , flange taps at position A.

Pipe Diameter $=10.366 \mathrm{~cm}(4.081 \mathrm{in}), 3.8 \mu \mathrm{m}$ Orifice Diameter $=5.7142 \mathrm{~cm}(2.2497 \mathrm{in})$

\begin{tabular}{|c|c|c|c|c|c|c|c|c|}
\hline Run ID & $\begin{array}{c}\text { Pressure } \\
\text { (MPa) }\end{array}$ & $\begin{array}{l}\text { Temperature } \\
\text { (K) }\end{array}$ & $\begin{array}{l}\text { Density } \\
\left(\mathrm{kg} / \mathrm{m}^{3}\right)\end{array}$ & $\begin{array}{l}\text { Dif Press } \\
\text { (kPa) }\end{array}$ & $\begin{array}{c}\text { Flow Rate } \\
(\mathrm{kg} / \mathrm{s})\end{array}$ & $\begin{array}{l}\text { Pipe Re No. } \\
\left(/ 10^{6}\right)\end{array}$ & C & $\mathrm{Cr}_{2}$ \\
\hline $\begin{array}{l}072391-1 \\
072391-2 \\
072391-3 \\
072391-4 \\
072391-5 \\
072391-6 \\
072391-7 \\
072391-8 \\
072391-9 \\
072491-1 \\
072491-2 \\
072491-3 \\
072491-4 \\
072491-5 \\
072491-6 \\
072491-7 \\
072491-8\end{array}$ & $\begin{array}{l}3.9063 \\
3.9033 \\
3.9852 \\
3.9845 \\
3.8042 \\
3.8020 \\
4.0061 \\
4.0072 \\
4.0060 \\
3.9210 \\
3.9224 \\
3.7411 \\
3.7414 \\
3.8331 \\
3.8327 \\
3.9360 \\
3.9381\end{array}$ & $\begin{array}{l}286.82 \\
287.25 \\
287.08 \\
286.71 \\
286.56 \\
287.11 \\
287.21 \\
287.91 \\
287.64 \\
287.82 \\
287.60 \\
287.09 \\
286.71 \\
287.61 \\
286.79 \\
287.72 \\
287.89\end{array}$ & $\begin{array}{l}46.26 \\
46.14 \\
47.15 \\
47.21 \\
45.09 \\
44.97 \\
47.37 \\
47.26 \\
47.29 \\
46.25 \\
46.31 \\
44.24 \\
44.31 \\
45.25 \\
45.39 \\
46.45 \\
46.44\end{array}$ & $\begin{array}{r}13.674 \\
13.517 \\
6.335 \\
6.323 \\
19.971 \\
20.009 \\
3.086 \\
3.109 \\
3.106 \\
6.193 \\
6.179 \\
20.053 \\
19.793 \\
13.652 \\
13.631 \\
3.420 \\
3.417\end{array}$ & $\begin{array}{l}1.8188 \\
1.8144 \\
1.2543 \\
1.2594 \\
2.1674 \\
2.1716 \\
0.8794 \\
0.8814 \\
0.8820 \\
1.2293 \\
1.2273 \\
2.1509 \\
2.1345 \\
1.7969 \\
1.7978 \\
0.9157 \\
0.9146\end{array}$ & $\begin{array}{l}1.2369 \\
1.2326 \\
0.8516 \\
0.8559 \\
1.4766 \\
1.4776 \\
0.5967 \\
0.5971 \\
0.5979 \\
0.8338 \\
0.8328 \\
1.4646 \\
1.4548 \\
1.2207 \\
1.2237 \\
0.6211 \\
0.6201\end{array}$ & $\begin{array}{l}0.6005 \\
0.6032 \\
0.6028 \\
0.6055 \\
0.5995 \\
0.6009 \\
0.6043 \\
0.6041 \\
0.6046 \\
0.6033 \\
0.6026 \\
0.5993 \\
0.5982 \\
0.6003 \\
0.6001 \\
0.6036 \\
0.6032\end{array}$ & $\begin{array}{l}0.6009 \\
0.6036 \\
0.6030 \\
0.6057 \\
0.6001 \\
0.6015 \\
0.6044 \\
0.6042 \\
0.6047 \\
0.6035 \\
0.6028 \\
0.6000 \\
0.5988 \\
0.6007 \\
0.6005 \\
0.6037 \\
0.6033\end{array}$ \\
\hline
\end{tabular}

Table 34. Measured and calculated quantities for 0.55 beta ratio, elbow at $170,1 T 1$ at 110 , flange taps at position $C$.

Pipe Diameter $=10.366 \mathrm{~cm}(4.081 \mathrm{in}), 3.8 \mu \mathrm{m}$ Orifice Diameter $=5.7142 \mathrm{~cm}(2.2497 \mathrm{in})$

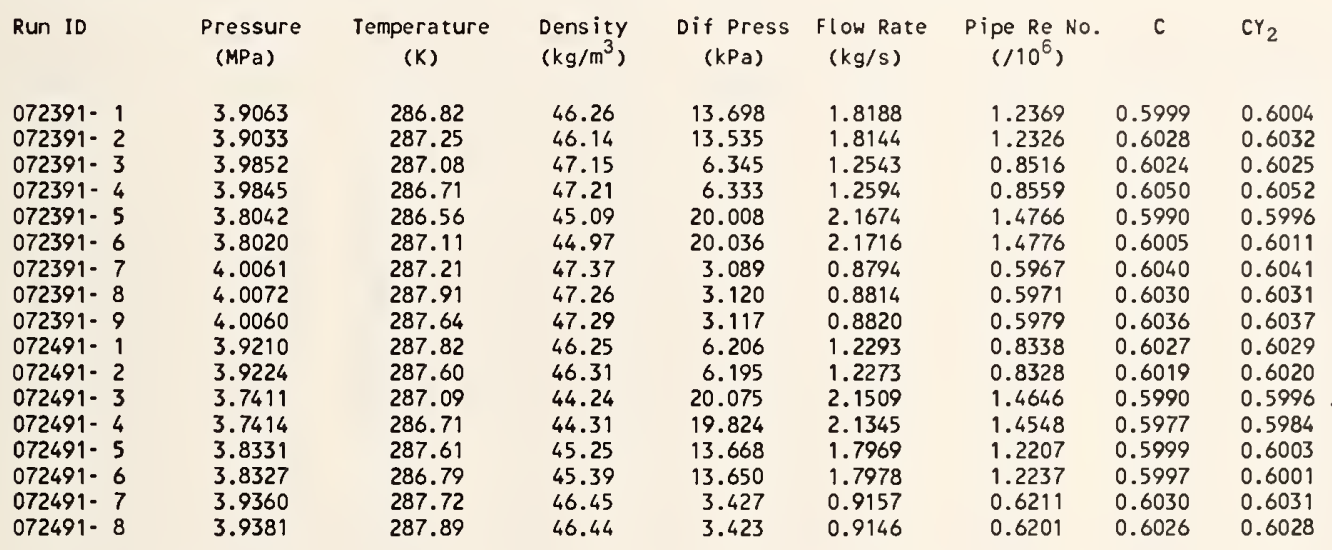

Table 35. Measured and calculated quantities for 0.67 beta ratio, elbow at 17D, 1 T1 at 130 , flange taps at position A.

Pipe Diameter $=10.366 \mathrm{~cm}(4.081 \mathrm{in}), 3.8 \mu \mathrm{m}$ Orifice Diameter $=6.9840 \mathrm{~cm}(2.7496 \mathrm{in})$

\begin{tabular}{|c|c|c|c|c|c|c|c|c|}
\hline Run ID & $\begin{array}{c}\text { Pressure } \\
\text { (MPa) }\end{array}$ & $\begin{array}{c}\text { Temperature } \\
\text { (K) }\end{array}$ & $\begin{array}{l}\text { Density } \\
\left(\mathrm{kg} / \mathrm{m}^{3}\right)\end{array}$ & $\begin{array}{l}\text { Dif Press } \\
\text { (kPa) }\end{array}$ & $\begin{array}{l}\text { Flow Rate } \\
(\mathrm{kg} / \mathrm{s})\end{array}$ & $\begin{array}{c}\text { Pipe Re No. } \\
\left(/ 10^{6}\right)\end{array}$ & C & $\mathrm{CY}_{2}$ \\
\hline $071691-1$ & 3.9484 & 283.22 & 47.42 & 2.569 & 1.2860 & 0.8817 & 0.6061 & 0.6062 \\
\hline $071691-2$ & 3.9491 & 282.41 & 47.57 & 2.561 & 1.2868 & 0.8841 & 0.6065 & 0.6066 \\
\hline $071691-3$ & 3.7710 & 279.56 & 45.93 & 8.125 & 2.2355 & 1.5502 & 0.6019 & 0.6021 \\
\hline $071691-4$ & 3.7719 & 279.43 & 45.97 & 8.011 & 2.2156 & 1.5368 & 0.6006 & 0.6008 \\
\hline $071691-5$ & 3.8468 & 280.76 & 46.64 & 6.240 & 1.9759 & 1.3647 & 0.6025 & 0.6026 \\
\hline $071691-6$ & 3.8449 & 280.47 & 46.67 & 6.236 & 1.9710 & 1.3624 & 0.6010 & 0.6012 \\
\hline $071691-7$ & 3.9100 & 284.31 & 46.75 & 4.159 & 1.6184 & 1.1073 & 0.6037 & 0.6038 \\
\hline $071691-8$ & 3.9117 & 282.09 & 47.18 & 4.128 & 1.6162 & 1.1117 & 0.6025 & 0.6026 \\
\hline $071991-1$ & 3.9300 & 287.20 & 46.47 & 4.147 & 1.6091 & 1.0929 & 0.6028 & 0.6029 \\
\hline $071991-2$ & 3.9300 & 287.03 & 46.50 & 4.147 & 1.6099 & 1.0939 & 0.6030 & 0.6031 \\
\hline $071991-3$ & 3.8639 & 285.99 & 45.90 & 5.977 & 1.9151 & 1.3056 & 0.6014 & 0.6015 \\
\hline $071991-4$ & 3.8650 & 286.45 & 45.83 & 5.950 & 1.9096 & 1.3004 & 0.6014 & 0.6016 \\
\hline $071991-5$ & 3.9687 & 287.03 & 46.96 & 2.649 & 1.2962 & 0.8803 & 0.6045 & 0.6046 \\
\hline $071991-6$ & 3.9659 & 286.87 & 46.95 & 2.661 & 1.3074 & 0.8883 & 0.6084 & 0.6085 \\
\hline $071991-7$ & 4.0010 & 286.89 & 47.37 & 2.681 & 1.3178 & 0.8950 & 0.6083 & 0.6084 \\
\hline $071991-8$ & 3.7974 & 285.15 & 45.25 & 7.781 & 2.1688 & 1.4828 & 0.6011 & 0.6013 \\
\hline $071991-9$ & 3.7961 & 286.49 & 45.00 & 7.706 & 2.1585 & 1.4709 & 0.6028 & 0.6030 \\
\hline $071991-10$ & 3.9299 & 286.43 & 46.61 & 3.920 & 1.5743 & 1.0713 & 0.6058 & 0.6059 \\
\hline $071991-1$ & 3.9849 & 286.83 & 47.19 & 2.690 & 1.3115 & 0.8910 & 0.6055 & 0.6056 \\
\hline $071991-2$ & 3.9506 & 286.00 & 46.93 & 4.103 & 1.6095 & 1.0961 & 0.6033 & 0.6034 \\
\hline $071991 \cdot 3$ & 3.8746 & 286.96 & 45.86 & 6.204 & 1.9497 & 1.3259 & 0.6011 & 0.6013 \\
\hline $071991-4$ & 3.8075 & 286.11 & 45.21 & 7.960 & 2.1925 & 1.4953 & 0.6010 & 0.6013 \\
\hline
\end{tabular}


Table 36. Measured and calculated quantities for 0.67 beta ratio, elbow at 17D, ITI at 13D, flange taps at position C. Pipe Diameter $=10.366 \mathrm{~cm}(4.081 \mathrm{in}), 3.8 \mu \mathrm{m}$ Orifice Diameter $=6.9840 \mathrm{~cm}(2.7496 \mathrm{in})$

\begin{tabular}{|c|c|c|c|c|c|c|c|c|}
\hline Run ID & $\begin{array}{c}\text { Pressure } \\
\text { (MPa) }\end{array}$ & $\begin{array}{c}\text { Temperature } \\
(\mathrm{K})\end{array}$ & $\begin{array}{l}\text { Density } \\
\left(\mathrm{kg} / \mathrm{m}^{3}\right)\end{array}$ & $\begin{array}{c}\text { Dif Press } \\
\text { (kPa) }\end{array}$ & $\begin{array}{c}\text { Flow Rate } \\
(\mathrm{kg} / \mathrm{s})\end{array}$ & $\begin{array}{l}\text { Pipe Re No. } \\
\left(/ 10^{6}\right)\end{array}$ & C & $\mathrm{Cr}_{2}$ \\
\hline 071691- 1 & 3.9484 & 283.22 & 47.42 & 2.573 & 1.2860 & 0.8817 & 0.6057 & 0.6057 \\
\hline $071691-2$ & 3.9491 & 282.41 & 47.57 & 2.565 & 1.2868 & 0.8841 & 0.6060 & 0.6060 \\
\hline $071691-3$ & 3.7710 & 279.56 & 45.93 & 8.135 & 2.2355 & 1.5502 & 0.6015 & 0.6018 \\
\hline $071691-4$ & 3.7719 & 279.43 & 45.97 & 8.022 & 2.2156 & 1.5368 & 0.6001 & 0.6004 \\
\hline $071691-5$ & 3.8468 & 280.76 & 46.64 & 6.241 & 1.9759 & 1.3637 & 0.6024 & 0.6026 \\
\hline $071691-6$ & 3.8449 & 280.47 & 46.67 & 6.237 & 1.9710 & 1.3624 & 0.6009 & 0.6011 \\
\hline $071691-7$ & 3.9100 & 284.31 & 46.75 & 4.166 & 1.6184 & 1.1073 & 0.6032 & 0.6033 \\
\hline $071691-8$ & 3.9117 & 282.09 & 47.18 & 4.135 & 1.6162 & 1.1117 & 0.6019 & 0.6020 \\
\hline $071991-1$ & 3.9300 & 287.20 & 46.47 & 4.169 & 1.6091 & 1.0929 & 0.6013 & 0.6014 \\
\hline $071991-2$ & 3.9300 & 287.03 & 46.50 & 4.170 & 1.6099 & 1.0939 & 0.6013 & 0.6014 \\
\hline $071991-3$ & 3.8639 & 285.99 & 45.90 & 5.997 & 1.9151 & 1.3056 & 0.6003 & 0.6005 \\
\hline $071991-4$ & 3.8650 & 286.45 & 45.83 & 5.971 & 1.9096 & 1.3004 & 0.6004 & 0.6005 \\
\hline $071991-5$ & 3.9687 & 287.03 & 46.96 & 2.660 & 1.2962 & 0.8803 & 0.6032 & 0.6033 \\
\hline $071991-6$ & 3.9659 & 286.87 & 46.95 & 2.679 & 1.3074 & 0.8883 & 0.6064 & 0.6064 \\
\hline $071991-7$ & 4.0010 & 286.89 & 47.37 & 2.697 & 1.3178 & 0.8950 & 0.6065 & 0.6065 \\
\hline $071991-8$ & 3.7974 & 285.15 & 45.25 & 7.815 & 2.1688 & 1.4828 & 0.5998 & 0.6000 \\
\hline 071991-9 & 3.7961 & 286.49 & 45.00 & 7.733 & 2.1585 & 1.4709 & 0.6017 & 0.6019 \\
\hline $071991-10$ & 3.9299 & 286.43 & 46.61 & 3.952 & 1.5743 & 1.0713 & 0.6033 & 0.6034 \\
\hline $071991-1$ & 3.9849 & 286.83 & 47.19 & 2.706 & 1.3115 & 0.8910 & 0.6037 & 0.6037 \\
\hline $071991-2$ & 3.9506 & 286.00 & 46.93 & 4.134 & 1.6095 & 1.0961 & 0.6010 & 0.6011 \\
\hline $071991-3$ & 3.8746 & 286.96 & 45.86 & 6.233 & 1.9497 & 1.3259 & 0.5998 & 0.5999 \\
\hline $071991-4$ & 3.8075 & 286.11 & 45.21 & 7.976 & 2.1925 & 1.4953 & 0.6004 & 0.6007 \\
\hline
\end{tabular}

Table 37. Measured and calculated quantities for 0.67 beta ratio, elbow at 17D, IT1 at 110 , flange taps at position A.

Pipe Diameter $=10.366 \mathrm{~cm}(4.081 \mathrm{in}), 3.8 \mu \mathrm{m}$ Orifice Diameter $=6.9840 \mathrm{~cm}(2.7496 \mathrm{in})$

\begin{tabular}{|c|c|c|c|c|c|c|c|c|}
\hline Run ID & $\begin{array}{l}\text { Pressure } \\
\text { (MPa) }\end{array}$ & $\begin{array}{l}\text { Temperature } \\
\text { (K) }\end{array}$ & $\begin{array}{l}\text { Density } \\
\left(\mathrm{kg} / \mathrm{m}^{3}\right)\end{array}$ & $\begin{array}{l}\text { Dif Press } \\
\text { (KPa) }\end{array}$ & $\begin{array}{l}\text { Flow Rate } \\
(\mathrm{kg} / \mathrm{s})\end{array}$ & $\begin{array}{l}\text { Pipe Re No. } \\
\left(/ 10^{6}\right)\end{array}$ & C & $\mathrm{Cr}_{2}$ \\
\hline $072399-1$ & 3.9610 & 286.66 & 46.94 & 4.080 & 1.6008 & 1.0883 & 0.6017 & 0.6018 \\
\hline $072391-2$ & 3.9615 & 286.36 & 46.99 & 4.051 & 1.5981 & 1.0872 & 0.6024 & 0.6025 \\
\hline $072391-3$ & 3.8311 & 285.81 & 45.54 & 7.915 & 2.1895 & 1.4940 & 0.5997 & 0.5999 \\
\hline $072391-4$ & 3.8305 & 285.38 & 45.61 & 7.743 & 2.1665 & 1.4798 & 0.5996 & 0.5998 \\
\hline $072391-5$ & 3.9883 & 287.39 & 47.13 & 2.681 & 1.3025 & 0.8836 & 0.6027 & 0.6027 \\
\hline $072391-6$ & 3.9889 & 287.07 & 47.19 & 2.716 & 1.3126 & 0.8911 & 0.6031 & 0.6032 \\
\hline $072391-7$ & 3.8875 & 286.75 & 46.05 & 6.100 & 1.9348 & 1.3163 & 0.6004 & 0.6006 \\
\hline $072391-8$ & 3.8890 & 287.32 & 45.96 & 6.073 & 1.9282 & 1.3099 & 0.6002 & 0.6004 \\
\hline $072491-1$ & 3.8199 & 286.80 & 45.23 & 6.156 & 1.9272 & 1.3119 & 0.6006 & 0.6008 \\
\hline $072491-2$ & 3.8211 & 287.22 & 45.18 & 6.131 & 1.9191 & 1.3051 & 0.5997 & 0.5999 \\
\hline $072491-3$ & 3.7459 & 287.12 & 44.30 & 8.062 & 2.1810 & 1.4849 & 0.6002 & 0.6004 \\
\hline $072491-4$ & 3.7472 & 285.42 & 44.60 & 7.994 & 2.1765 & 1.4879 & 0.5994 & 0.5996 \\
\hline $072491-5$ & 3.8835 & 287.27 & 45.91 & 4.143 & 1.5969 & 1.0850 & 0.6022 & 0.6023 \\
\hline $072499 \cdot 6$ & 3.8825 & 287.09 & 45.92 & 4.159 & 1.5974 & 1.0858 & 0.6011 & 0.6012 \\
\hline $072491-7$ & 3.9218 & 287.43 & 46.33 & 2.679 & 1.2946 & 0.8789 & 0.6044 & 0.6045 \\
\hline $072491-8$ & .9202 & 287.25 & 46.34 & 2.682 & 1.2936 & 0.8786 & 0.6036 & 0.6036 \\
\hline
\end{tabular}

Table 38. Measured and calculated quantities for 0.67 beta ratio, elbow at 17D, IT1 at 110 , flange taps at position C.

Pipe Diameter $=10.366 \mathrm{~cm}(4.081 \mathrm{in}), 3.8 \mu \mathrm{m}$ Orifice Diameter $=6.9840 \mathrm{~cm}(2.7496 \mathrm{in})$

\begin{tabular}{|c|c|c|c|c|c|c|c|c|}
\hline Run ID & $\begin{array}{l}\text { Pressure } \\
\text { (MPa) }\end{array}$ & $\begin{array}{c}\text { Temperature } \\
\text { (K) }\end{array}$ & $\begin{array}{l}\text { Density } \\
\left(\mathrm{kg} / \mathrm{m}^{3}\right)\end{array}$ & $\begin{array}{c}\text { Dif Press } \\
\text { (kPa) }\end{array}$ & $\begin{array}{c}\text { Flow Rate } \\
(\mathrm{kg} / \mathrm{s})\end{array}$ & $\begin{array}{c}\text { Pipe Re No. } \\
\left(/ 10^{6}\right)\end{array}$ & C & $\mathrm{Cr}_{2}$ \\
\hline 072391- 1 & 3.9610 & 286.66 & 46.94 & 4.101 & 1.6008 & 1.0883 & 0.6001 & 0.6002 \\
\hline $072391-2$ & 3.9615 & 286.36 & 46.99 & 4.078 & 1.5981 & 1.0872 & 0.6004 & 0.6005 \\
\hline $072391-3$ & 3.8311 & 285.81 & 45.54 & 7.941 & 2.1895 & 1.4940 & 0.5988 & 0.5990 \\
\hline $072391-4$ & 3.8305 & 285.38 & 45.61 & 7.772 & 2.1665 & 1.4798 & 0.5985 & 0.5987 \\
\hline $072391-5$ & 3.9883 & 287.39 & 47.13 & 2.690 & 1.3025 & 0.8836 & 0.6018 & 0.6018 \\
\hline $072391-6$ & 3.9889 & 287.07 & 47.19 & 2.726 & 1.3126 & 0.8911 & 0.6020 & 0.6021 \\
\hline $072391-7$ & 3.8875 & 286.75 & 46.05 & 6.134 & 1.9348 & 1.3163 & 0.5987 & 0.5989 \\
\hline $072391-8$ & 3.8890 & 287.32 & 45.96 & 6.098 & 1.9282 & 1.3099 & 0.5990 & 0.5991 \\
\hline $072491-1$ & 3.8199 & 286.80 & 45.23 & 6.180 & 1.9272 & 1.3119 & 0.5994 & 0.5996 \\
\hline $072491-2$ & 3.8211 & 287.22 & 45.18 & 6.147 & 1.9191 & 1.3051 & 0.5989 & 0.5991 \\
\hline $072491-3$ & 3.7459 & 287.12 & 44.30 & 8.091 & 2.1810 & 1.4849 & 0.5991 & 0.5993 \\
\hline $072491 \cdot 4$ & 3.7472 & 285.42 & 44.60 & 8.012 & 2.1765 & 1.4879 & 0.5987 & 0.5989 \\
\hline $072491-5$ & 3.8835 & 287.27 & 45.91 & 4.159 & 1.5969 & 1.0850 & 0.6011 & 0.6012 \\
\hline $072491-6$ & 3.8825 & 287.09 & 45.92 & 4.174 & 1.5974 & 1.0858 & 0.6001 & 0.6002 \\
\hline $072491-7$ & 3.9218 & 287.43 & 46.33 & 2.686 & 1.2946 & 0.8789 & 0.6036 & 0.6037 \\
\hline $072491-8$ & 3.9202 & 287.25 & 46.34 & 2.685 & 1.2936 & 0.8786 & 0.6032 & 0.6032 \\
\hline
\end{tabular}


Table 39. Measured and calculated quantities for 0.73 beta ratio, elbow at 170, 1T1 at 150, flange taps at position A.

Pipe Diameter $=10.366 \mathrm{~cm}(4.081 \mathrm{in}), 3.8 \mu \mathrm{m}$ Orifice Diameter $=7.6197 \mathrm{~cm}(2.9999 \mathrm{in})$

\begin{tabular}{|c|c|c|c|c|c|c|c|c|}
\hline Run 10 & $\begin{array}{c}\text { Pressure } \\
\text { (MPa) }\end{array}$ & $\begin{array}{l}\text { Temperature } \\
\text { (K) }\end{array}$ & $\begin{array}{l}\text { Density } \\
\left(\mathrm{kg} / \mathrm{m}^{3}\right)\end{array}$ & $\begin{array}{l}\text { Dif Press } \\
\text { (kPa) }\end{array}$ & $\begin{array}{c}\text { Flow Rate } \\
(\mathrm{kg} / \mathrm{s})\end{array}$ & $\begin{array}{l}\text { Pipe Re No. } \\
\left(/ 10^{5}\right)\end{array}$ & C & $\mathrm{CY}_{2}$ \\
\hline $\begin{array}{l}061191-1 \\
061191-2 \\
061191-3 \\
061191-4 \\
061191-5 \\
061191-6 \\
061191-7 \\
061191-8 \\
071291-1 \\
071291-2 \\
071291-3 \\
071291-4 \\
071291-5 \\
071291-6 \\
071291-7 \\
071291-8\end{array}$ & $\begin{array}{l}3.9426 \\
3.9490 \\
3.8258 \\
3.8240 \\
3.9577 \\
3.9721 \\
3.8723 \\
3.8693 \\
3.9033 \\
3.9041 \\
3.8311 \\
3.8347 \\
3.9286 \\
3.9295 \\
3.7868 \\
3.7929\end{array}$ & $\begin{array}{l}284.94 \\
285.55 \\
284.89 \\
284.62 \\
286.21 \\
286.09 \\
284.21 \\
285.29 \\
284.87 \\
284.52 \\
283.82 \\
282.87 \\
283.34 \\
283.71 \\
282.64 \\
281.91\end{array}$ & $\begin{array}{l}47.03 \\
46.99 \\
45.64 \\
45.66 \\
46.98 \\
47.17 \\
46.32 \\
46.09 \\
46.57 \\
46.64 \\
45.89 \\
46.11 \\
47.16 \\
47.10 \\
45.57 \\
45.77\end{array}$ & $\begin{array}{l}3.327 \\
3.331 \\
5.098 \\
5.050 \\
2.649 \\
2.684 \\
4.201 \\
4.197 \\
3.194 \\
3.173 \\
4.462 \\
4.396 \\
2.582 \\
2.600 \\
5.133 \\
5.025\end{array}$ & $\begin{array}{l}1.8218 \\
1.8254 \\
2.2208 \\
2.2098 \\
1.6316 \\
1.6404 \\
2.0359 \\
2.0312 \\
1.7843 \\
1.7795 \\
2.0868 \\
2.0760 \\
1.6152 \\
1.6188 \\
2.2307 \\
2.2172\end{array}$ & $\begin{array}{l}1.2440 \\
1.2445 \\
1.5188 \\
1.5123 \\
1.1105 \\
1.1166 \\
1.3938 \\
1.3870 \\
1.2192 \\
1.2169 \\
1.4308 \\
1.4266 \\
1.1074 \\
1.1089 \\
1.5347 \\
1.5281\end{array}$ & $\begin{array}{l}0.6010 \\
0.6020 \\
0.6008 \\
0.6005 \\
0.6035 \\
0.6016 \\
0.6023 \\
0.6027 \\
0.6037 \\
0.6036 \\
0.6017 \\
0.6018 \\
0.6041 \\
0.6037 \\
0.6019 \\
0.6033\end{array}$ & $\begin{array}{l}0.6011 \\
0.6021 \\
0.6009 \\
0.6006 \\
0.6036 \\
0.6017 \\
0.6024 \\
0.6028 \\
0.6038 \\
0.6037 \\
0.6019 \\
0.6019 \\
0.6041 \\
0.6038 \\
0.6020 \\
0.6034\end{array}$ \\
\hline
\end{tabular}

Table 40. Measured and calculated quantities for 0.73 beta ratio, elbow at 17D, $1 T 1$ at 150 , flange taps at position $C$.

Pipe Diameter $=10.366 \mathrm{~cm}(4.081 \mathrm{in}), 3.8 \mu \mathrm{m}$ Orifice Diameter $=7.6197 \mathrm{~cm}(2.9999 \mathrm{in})$

\begin{tabular}{|c|c|c|c|c|c|c|c|c|}
\hline Run ID & $\begin{array}{l}\text { Pressure } \\
\text { (MPa) }\end{array}$ & $\begin{array}{c}\text { Temperature } \\
\text { (K) }\end{array}$ & $\begin{array}{l}\text { Density } \\
\left(\mathrm{kg} / \mathrm{m}^{3}\right)\end{array}$ & $\begin{array}{c}\text { Dif Press } \\
\text { (kPa) }\end{array}$ & $\begin{array}{c}\text { Flow Rate } \\
(\mathrm{kg} / \mathrm{s})\end{array}$ & $\begin{array}{c}\text { Pipe Re No. } \\
\left(/ 10^{5}\right)\end{array}$ & $c$ & $\mathrm{Cr}_{2}$ \\
\hline $\begin{array}{l}061191-1 \\
061191-2 \\
061191-3 \\
061191-4 \\
061191-5 \\
061191-6 \\
061191-7 \\
061191-8 \\
071291-1 \\
071291-2 \\
071291-3 \\
071291-4 \\
071291-5 \\
071291-6 \\
071291-7 \\
071291-8\end{array}$ & $\begin{array}{l}3.9426 \\
3.9490 \\
3.8258 \\
3.8240 \\
3.9577 \\
3.9721 \\
3.8723 \\
3.8693 \\
3.9033 \\
3.9041 \\
3.8311 \\
3.8347 \\
3.9286 \\
3.9295 \\
3.7868 \\
3.7929\end{array}$ & $\begin{array}{l}284.94 \\
285.55 \\
284.89 \\
284.62 \\
286.21 \\
286.09 \\
284.21 \\
285.29 \\
284.87 \\
284.52 \\
283.82 \\
282.87 \\
283.34 \\
283.71 \\
282.64 \\
281.91\end{array}$ & $\begin{array}{l}47.03 \\
46.99 \\
45.64 \\
45.66 \\
46.98 \\
47.17 \\
46.32 \\
46.09 \\
46.57 \\
46.64 \\
45.89 \\
46.11 \\
47.16 \\
47.10 \\
45.57 \\
45.77\end{array}$ & $\begin{array}{l}3.348 \\
3.346 \\
5.126 \\
5.074 \\
2.656 \\
2.691 \\
4.220 \\
4.219 \\
3.207 \\
3.185 \\
4.471 \\
4.409 \\
2.585 \\
2.606 \\
5.154 \\
5.051\end{array}$ & $\begin{array}{l}1.8218 \\
1.8254 \\
2.2208 \\
2.2098 \\
1.6316 \\
1.6404 \\
2.0359 \\
2.0312 \\
1.7843 \\
1.7795 \\
2.0868 \\
2.0760 \\
1.6152 \\
1.6188 \\
2.2307 \\
2.2172\end{array}$ & $\begin{array}{l}1.2440 \\
1.2445 \\
1.5188 \\
1.5123 \\
1.1105 \\
1.1166 \\
1.3938 \\
1.3870 \\
1.2192 \\
1.2169 \\
1.4306 \\
1.4266 \\
1.1074 \\
1.1089 \\
1.5347 \\
1.5281\end{array}$ & $\begin{array}{l}0.5991 \\
0.6007 \\
0.5991 \\
0.5991 \\
0.6028 \\
0.6008 \\
0.6010 \\
0.6011 \\
0.6026 \\
0.6025 \\
0.6012 \\
0.6009 \\
0.6038 \\
0.6030 \\
0.6006 \\
0.6018\end{array}$ & $\begin{array}{l}0.5992 \\
0.6008 \\
0.5993 \\
0.5992 \\
0.6028 \\
0.6009 \\
0.6011 \\
0.6012 \\
0.6026 \\
0.6026 \\
0.6013 \\
0.6010 \\
0.6039 \\
0.6031 \\
0.6008 \\
0.6019\end{array}$ \\
\hline
\end{tabular}

Table 41. Measured and calculated quantities for 0.73 beta ratio, elbow at 17D, IT1 at 13D, flange taps at position A.

Pipe Diameter $=10.366 \mathrm{~cm}(4.081 \mathrm{in}), 3.8 \mu \mathrm{m}$ Orifice Diameter $=7.6197 \mathrm{~cm}(2.9999 \mathrm{in})$

\begin{tabular}{|c|c|c|c|c|c|c|c|c|}
\hline Run ID & $\begin{array}{c}\text { Pressure } \\
\text { (MPa) }\end{array}$ & $\begin{array}{c}\text { Temperature } \\
\text { (K) }\end{array}$ & $\begin{array}{l}\text { Density } \\
\left(\mathrm{kg} / \mathrm{m}^{3}\right)\end{array}$ & $\begin{array}{c}\text { Dif Press } \\
(\mathrm{kPa})\end{array}$ & $\begin{array}{c}\text { Flow Rate } \\
(\mathrm{kg} / \mathrm{s})\end{array}$ & $\begin{array}{l}\text { Pipe Re No. } \\
\left(/ 10^{5}\right)\end{array}$ & C & $\mathrm{CY}_{2}$ \\
\hline $071691-1$ & 3.9361 & 283.42 & 47.23 & 2.640 & 1.6313 & 1.1181 & 0.6029 & 0.6030 \\
\hline $071691 \cdot 2$ & 3.9337 & 283.18 & 47.24 & 2.637 & 1.6283 & 1.1168 & 0.6021 & 0.6021 \\
\hline $071691-3$ & 3.8412 & 283.31 & 46.11 & 4.274 & 2.0434 & 1.4027 & 0.6007 & 0.6008 \\
\hline $071691-4$ & 3.8379 & 282.21 & 46.26 & 4.175 & 2.0177 & 1.3888 & 0.5992 & 0.5993 \\
\hline $071691-5$ & 3.8849 & 283.63 & 46.57 & 3.339 & 1.8194 & 1.2472 & 0.6021 & 0.6022 \\
\hline $071691-6$ & 3.8838 & 283.77 & 46.54 & 3.359 & 1.8202 & 1.2473 & 0.6008 & 0.6009 \\
\hline $071691-7$ & 3.7856 & 282.40 & 45.60 & 5.134 & 2.2261 & 1.5325 & 0.6004 & 0.6005 \\
\hline $071691-8$ & 3.7818 & 282.46 & 45.54 & 5.074 & 2.2054 & 1.5181 & 0.5987 & 0.5988 \\
\hline $071991-1$ & 3.9617 & 286.83 & 46.91 & 2.545 & 1.5920 & 1.0818 & 0.6012 & 0.6012 \\
\hline $071991-2$ & 3.9605 & 286.52 & 46.95 & 2.537 & 1.5939 & 1.0840 & 0.6026 & 0.6026 \\
\hline $071991-3$ & 3.9227 & 286.16 & 46.57 & 3.163 & 1.7669 & 1.2032 & 0.6008 & 0.6008 \\
\hline $071991-4$ & 3.9226 & 285.94 & 46.61 & 3.152 & 1.7660 & 1.2032 & 0.6013 & 0.6014 \\
\hline $071991-5$ & 3.8690 & 285.91 & 45.97 & 4.131 & 2.0023 & 1.3653 & 0.5996 & 0.5997 \\
\hline $071991-6$ & 3.8684 & 285.43 & 46.05 & 4.104 & 1.9982 & 1.3641 & 0.5998 & 0.5999 \\
\hline $071991-7$ & 3.8014 & 285.74 & 45.20 & 5.259 & 2.2356 & 1.5262 & 0.5983 & 0.5984 \\
\hline $071991-8$ & 3.8050 & 285.11 & 45.35 & 5.168 & 2.2269 & 1.5225 & 0.6002 & 0.6003 \\
\hline
\end{tabular}


Table 42. Measured and calculated quantities for 0.73 beta ratio, elbow at 170, II 1 at 130 , flange taps at position $\mathrm{C}$.

Pipe Diameter $=10.366 \mathrm{~cm}(4.081 \mathrm{in}), 3.8 \mu \mathrm{m}$ Orifice Diameter $=7.6197 \mathrm{~cm}(2.9999 \mathrm{in})$

\begin{tabular}{|c|c|c|c|c|c|c|c|c|}
\hline Run 10 & $\begin{array}{l}\text { Pressure } \\
\text { (MPa) }\end{array}$ & $\begin{array}{l}\text { Temperature } \\
\text { (K) }\end{array}$ & $\begin{array}{l}\text { Density } \\
\left(\mathrm{kg} / \mathrm{m}^{3}\right)\end{array}$ & $\begin{array}{l}\text { Dif Press } \\
\text { (kPa) }\end{array}$ & $\begin{array}{l}\text { Flow Rate } \\
(\mathrm{kg} / \mathrm{s})\end{array}$ & $\begin{array}{c}\text { Pipe Re No. } \\
\left(/ 10^{6}\right)\end{array}$ & c & $\mathrm{CY}_{2}$ \\
\hline $\begin{array}{l}071691-1 \\
071691-2 \\
071691-3 \\
071691-4 \\
071691-5 \\
071691-6 \\
071691-7 \\
071691-8 \\
071991-1 \\
071991-2 \\
071991-3 \\
071991-4 \\
071991-5 \\
071991-6 \\
071991-7 \\
071991-8\end{array}$ & $\begin{array}{l}3.9361 \\
3.9337 \\
3.8412 \\
3.8379 \\
3.8849 \\
3.8838 \\
3.7856 \\
3.7818 \\
3.9617 \\
3.9605 \\
3.9227 \\
3.9226 \\
3.8690 \\
3.8684 \\
3.8014 \\
3.8050\end{array}$ & $\begin{array}{l}283.42 \\
283.18 \\
283.31 \\
282.21 \\
283.63 \\
283.77 \\
282.40 \\
282.46 \\
286.83 \\
286.52 \\
286.16 \\
285.94 \\
285.91 \\
285.43 \\
285.74 \\
285.11\end{array}$ & $\begin{array}{l}47.23 \\
47.24 \\
46.11 \\
46.26 \\
46.57 \\
46.54 \\
45.60 \\
45.54 \\
46.91 \\
46.95 \\
46.57 \\
46.61 \\
45.97 \\
46.05 \\
45.20 \\
45.35\end{array}$ & $\begin{array}{l}2.647 \\
2.643 \\
4.294 \\
4.191 \\
3.353 \\
3.373 \\
5.143 \\
5.090 \\
2.569 \\
2.560 \\
3.195 \\
3.183 \\
4.170 \\
4.141 \\
5.288 \\
5.200\end{array}$ & $\begin{array}{l}1.6313 \\
1.6283 \\
2.0434 \\
2.0177 \\
1.8194 \\
1.8202 \\
2.2261 \\
2.2054 \\
1.5920 \\
1.5939 \\
1.7669 \\
1.7660 \\
2.0023 \\
1.9982 \\
2.2356 \\
2.2269\end{array}$ & $\begin{array}{l}1.1181 \\
1.1168 \\
1.4027 \\
1.3888 \\
1.2472 \\
1.2473 \\
1.5325 \\
1.5181 \\
1.0818 \\
1.0840 \\
1.2032 \\
1.2032 \\
1.3653 \\
1.3641 \\
1.5262 \\
1.5225\end{array}$ & $\begin{array}{l}0.6022 \\
0.6014 \\
0.5993 \\
0.5980 \\
0.6009 \\
0.5996 \\
0.5999 \\
0.5978 \\
0.5984 \\
0.5999 \\
0.5978 \\
0.5983 \\
0.5968 \\
0.5971 \\
0.5967 \\
0.5984\end{array}$ & $\begin{array}{l}0.6022 \\
0.6014 \\
0.5994 \\
0.5981 \\
0.6009 \\
0.5997 \\
0.6000 \\
0.5979 \\
0.5984 \\
0.6000 \\
0.5979 \\
0.5984 \\
0.5969 \\
0.5972 \\
0.5968 \\
0.5985\end{array}$ \\
\hline
\end{tabular}

Table 43. Measured and calculated quantities for 0.73 beta ratio, elbow at 170,171 at 110 , flange taps at position A.

Pipe Diameter $=10.366 \mathrm{~cm}(4.081 \mathrm{in}), 3.8 \mu \mathrm{m}$ Orifice Diameter $=7.6197 \mathrm{~cm}(2.9999 \mathrm{in})$

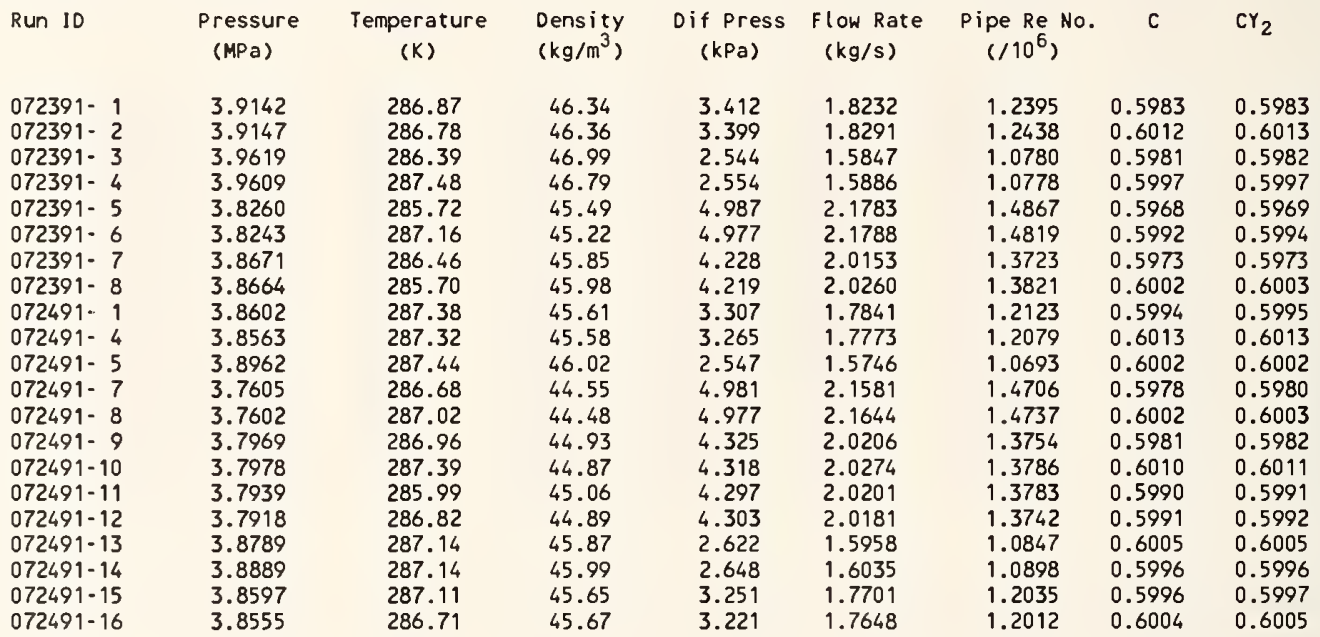

Table 44. Measured and calculated quantities for 0.73 beta ratio, elbow at $170,1 \mathrm{~T} 1$ at 110 , flange taps at position $\mathrm{C}$.

Pipe 0 iameter $=10.366 \mathrm{~cm}(4.081 \mathrm{in}), 3.8 \mu \mathrm{m}$ Orifice Diameter $=7.6197 \mathrm{~cm}(2.9999 \mathrm{in})$

\begin{tabular}{|c|c|c|c|c|c|c|c|c|}
\hline Run ID & $\begin{array}{c}\text { Pressure } \\
\text { (MPa) }\end{array}$ & $\begin{array}{c}\text { Temperature } \\
\text { (K) }\end{array}$ & $\begin{array}{l}\text { Density } \\
\left(\mathrm{kg} / \mathrm{m}^{3}\right)\end{array}$ & $\begin{array}{c}\text { Dif Press } \\
\text { (kPa) }\end{array}$ & $\begin{array}{c}\text { Flow Rate } \\
\text { (kg/s) }\end{array}$ & $\begin{array}{l}\text { Pipe Re No. } \\
\left(/ 10^{6}\right)\end{array}$ & $c$ & $\mathrm{Cr}_{2}$ \\
\hline $072391-1$ & 3.9142 & 286.87 & 46.34 & 3.439 & 1.8232 & 1.2395 & 0.5959 & 0.5960 \\
\hline $072391-2$ & 3.9147 & 286.78 & 46.36 & 3.421 & 1.8291 & 1.2438 & 0.5993 & 0.5994 \\
\hline $072391-3$ & 3.9619 & 286.39 & 46.99 & 2.555 & 1.5847 & 1.0780 & 0.5968 & 0.5968 \\
\hline $072391 \cdot 4$ & 3.9609 & 287.48 & 46.79 & 2.571 & 1.5886 & 1.0778 & 0.5977 & 0.5978 \\
\hline $072391-5$ & 3.8260 & 285.72 & 45.49 & 5.014 & 2.1783 & 1.4867 & 0.5951 & 0.5952 \\
\hline $072391-6$ & 3.8243 & 287.16 & 45.22 & 5.012 & 2.1788 & 1.4819 & 0.5972 & 0.5973 \\
\hline $072391-7$ & 3.8671 & 286.46 & 45.85 & 4.252 & 2.0153 & 1.3723 & 0.5956 & 0.5957 \\
\hline $072391-8$ & 3.8664 & 285.70 & 45.98 & 4.246 & 2.0260 & 1.3821 & 0.5983 & 0.5984 \\
\hline $072491-1$ & 3.8602 & 287.38 & 45.61 & 3.325 & 1.7841 & 1.2123 & 0.5978 & 0.5979 \\
\hline $072491-4$ & 3.8563 & 287.32 & 45.58 & 3.282 & 1.7773 & 1.2079 & 0.5997 & 0.5998 \\
\hline $072491-5$ & 3.8962 & 287.44 & 46.02 & 2.555 & 1.5746 & 1.0693 & 0.5992 & 0.5992 \\
\hline $072491-7$ & 3.7605 & 286.68 & 44.55 & 4.999 & 2.1581 & 1.4706 & 0.5967 & 0.5968 \\
\hline $072491-8$ & 3.7602 & 287.02 & 44.48 & 4.996 & 2.1644 & 1.4737 & 0.5990 & 0.5992 \\
\hline $072491-9$ & 3.7969 & 286.96 & 44.93 & 4.340 & 2.0206 & 1.3754 & 0.5971 & 0.5972 \\
\hline $072491-10$ & 3.7978 & 287.39 & 44.87 & 4.338 & 2.0274 & 1.3786 & 0.5996 & 0.5997 \\
\hline $072491-11$ & 3.7939 & 285.99 & 45.06 & 4.316 & 2.0201 & 1.3783 & 0.5977 & 0.5978 \\
\hline $072491-12$ & 3.7918 & 286.82 & 44.89 & 4.320 & 2.0181 & 1.3742 & 0.5979 & 0.5980 \\
\hline $072491-13$ & 3.8789 & 287.14 & 45.87 & 2.627 & 1.5958 & 1.0847 & 0.5999 & 0.6000 \\
\hline $072491-14$ & 3.8889 & 287.14 & 45.99 & 2.655 & 1.6035 & 1.0898 & 0.5988 & 0.5988 \\
\hline $072491-15$ & 3.8597 & 287.11 & 45.65 & 3.267 & 1.7701 & 1.2035 & 0.5981 & 0.5982 \\
\hline $072491-16$ & 3.8555 & 286.71 & 45.67 & 3.237 & 1.7648 & 1.2012 & 0.5990 & 0.5990 \\
\hline
\end{tabular}


Table 45. Measured and calculated quantities for 0.55 beta ratio, elbow at 170 , Zanker at $16 \mathrm{D}$, flange taps at position $\mathrm{A}$. Pipe Diameter $=10.366 \mathrm{~cm}(4.081 \mathrm{in}), 3.8 \mu \mathrm{m}$ Orifice Diameter $=5.7142 \mathrm{~cm}(2.2497 \mathrm{in})$

\begin{tabular}{|c|c|c|c|c|c|c|c|c|}
\hline Run 1D & $\begin{array}{c}\text { Pressure } \\
\text { (MPa) }\end{array}$ & $\begin{array}{c}\text { Temperature } \\
\text { (K) }\end{array}$ & $\begin{array}{l}\text { Density } \\
\left(\mathrm{kg} / \mathrm{m}^{3}\right)\end{array}$ & $\begin{array}{c}\text { Dif Press } \\
\text { (kPa) }\end{array}$ & $\begin{array}{l}\text { Flow Rate } \\
(\mathrm{kg} / \mathrm{s})\end{array}$ & $\begin{array}{c}\text { Pipe Re No. } \\
\left(/ 10^{6}\right)\end{array}$ & C & $\mathrm{CY}_{2}$ \\
\hline $061291-1$ & 3.9029 & 285.23 & 46.50 & 13.355 & 1.8076 & 1.2340 & 0.6023 & 0.6027 \\
\hline $061291-2$ & 3.9027 & 285.16 & 46.51 & 13.318 & 1.8068 & 1.2337 & 0.6028 & 0.6032 \\
\hline $061291-1$ & 4.0063 & 286.69 & 47.47 & 2.971 & 0.8641 & 0.5871 & 0.6046 & 0.6047 \\
\hline $061291-2$ & 4.0045 & 286.68 & 47.45 & 2.954 & 0.8615 & 0.5853 & 0.6046 & 0.6047 \\
\hline $061291-3$ & 3.7715 & 285.14 & 44.94 & 21.547 & 2.2565 & 1.5433 & 0.6018 & 0.6025 \\
\hline $061291-4$ & 3.7732 & 284.75 & 45.03 & 21.277 & 2.2446 & 1.5366 & 0.6019 & 0.6025 \\
\hline $061291-5$ & 3.9631 & 285.37 & 47.20 & 6.598 & 1.2812 & 0.8737 & 0.6031 & 0.6033 \\
\hline $061291 \cdot 6$ & 3.9593 & 285.54 & 47.12 & 6.773 & 1.2974 & 0.8844 & 0.6033 & 0.6035 \\
\hline $061291-7$ & 3.9717 & 286.17 & 47.15 & 6.754 & 1.3024 & 0.8864 & 0.6062 & 0.6064 \\
\hline $061291-8$ & 3.7987 & 285.12 & 45.27 & 6.030 & 1.2000 & 0.8205 & 0.6033 & 0.6035 \\
\hline $061291-9$ & 3.9574 & 286.07 & 47.00 & 2.854 & 0.8433 & 0.5741 & 0.6049 & 0.6050 \\
\hline 061391- & 4.0134 & 285.75 & 47.73 & 6.254 & 1.2548 & 0.8544 & 0.6033 & 0.6035 \\
\hline 061391 - & 4.0135 & 285.72 & 47.74 & 6.259 & 1.2563 & 0.8555 & 0.6037 & 0.6039 \\
\hline $061391-4$ & 3.7819 & 286.11 & 44.90 & 19.599 & 2.1435 & 1.4623 & 0.5998 & 0.6004 \\
\hline $061391-5$ & 3.7838 & 285.02 & 45.11 & 19.490 & 2.1445 & 1.4669 & 0.6003 & 0.6009 \\
\hline $061391-6$ & 3.8766 & 285.73 & 46.10 & 13.151 & 1.7839 & 1.2168 & 0.6016 & 0.6020 \\
\hline $061391-7$ & 3.8738 & 285.46 & 46.11 & 13.174 & 1.7846 & 1.2181 & 0.6012 & 0.6016 \\
\hline $061391-8$ & 4.0172 & 286.41 & 47.65 & 3.097 & 0.8852 & 0.6018 & 0.6055 & 0.6056 \\
\hline $061391-9$ & 4.0267 & 286.73 & 47.70 & 3.096 & 0.8867 & 0.6023 & 0.6062 & 0.6063 \\
\hline
\end{tabular}

Table 46. Measured and calculated quantities for 0.55 beta ratio, elbow at 170 , Zanker at 160 , flange taps at position $\mathrm{C}$. Pipe Diameter $=10.366 \mathrm{~cm}(4.081 \mathrm{in}), 3.8 \mu \mathrm{m}$ Orifice Diameter $=5.7142 \mathrm{~cm}(2.2497 \mathrm{in})$

\begin{tabular}{|c|c|c|c|c|c|c|c|c|}
\hline Run ID & $\begin{array}{c}\text { Pressure } \\
\text { (MPa) }\end{array}$ & $\begin{array}{c}\text { Temperature } \\
\text { (K) }\end{array}$ & $\begin{array}{l}\text { Density } \\
\left(\mathrm{kg} / \mathrm{m}^{3}\right)\end{array}$ & $\begin{array}{c}\text { Dif Press } \\
\text { (KPa) }\end{array}$ & $\begin{array}{c}\text { Flow Rate } \\
(\mathrm{kg} / \mathrm{s})\end{array}$ & $\begin{array}{l}\text { Pipe Re No. } \\
\left(/ 10^{6}\right)\end{array}$ & C & $\mathrm{CY}_{2}$ \\
\hline $\begin{array}{l}061291-1 \\
061291-2 \\
061291-1 \\
061291-2 \\
061291-3 \\
061291-4 \\
061291-5 \\
061291-6 \\
061291-7 \\
061291-8 \\
061291-9 \\
061391-1 \\
061391-2 \\
061391-4 \\
061391-5 \\
061391-6 \\
061391-7 \\
061391-8 \\
061391-9\end{array}$ & $\begin{array}{l}3.9029 \\
3.9027 \\
4.0063 \\
4.0045 \\
3.7715 \\
3.7732 \\
3.9631 \\
3.9593 \\
3.9717 \\
3.7987 \\
3.9574 \\
4.0134 \\
4.0135 \\
3.7819 \\
3.7838 \\
3.8766 \\
3.8738 \\
4.0172 \\
4.0267\end{array}$ & $\begin{array}{l}285.23 \\
285.16 \\
286.69 \\
286.68 \\
285.14 \\
284.75 \\
285.37 \\
285.54 \\
286.17 \\
285.12 \\
286.07 \\
285.75 \\
285.72 \\
286.11 \\
285.02 \\
285.73 \\
285.46 \\
286.41 \\
286.73\end{array}$ & $\begin{array}{l}46.50 \\
46.51 \\
47.47 \\
47.45 \\
44.94 \\
45.03 \\
47.20 \\
47.12 \\
47.15 \\
45.27 \\
47.00 \\
47.73 \\
47.74 \\
44.90 \\
45.11 \\
46.10 \\
46.11 \\
47.65 \\
47.70\end{array}$ & $\begin{array}{r}13.347 \\
13.317 \\
2.966 \\
2.948 \\
21.548 \\
21.271 \\
6.582 \\
6.767 \\
6.740 \\
6.017 \\
2.846 \\
6.250 \\
6.257 \\
19.590 \\
19.484 \\
13.147 \\
13.174 \\
3.106 \\
3.102\end{array}$ & $\begin{array}{l}1.8076 \\
1.8068 \\
0.8641 \\
0.8615 \\
2.2565 \\
2.2446 \\
1.2812 \\
1.2974 \\
1.3024 \\
1.2000 \\
0.8433 \\
1.2548 \\
1.2563 \\
2.1435 \\
2.1445 \\
1.7839 \\
1.7846 \\
0.8852 \\
0.8867\end{array}$ & $\begin{array}{l}1.2340 \\
1.2337 \\
0.5871 \\
0.5853 \\
1.5433 \\
1.5366 \\
0.8737 \\
0.8844 \\
0.8864 \\
0.8205 \\
0.5741 \\
0.8544 \\
0.8555 \\
1.4623 \\
1.4669 \\
1.2168 \\
1.2181 \\
0.6018 \\
0.6023\end{array}$ & $\begin{array}{l}0.6025 \\
0.6028 \\
0.6051 \\
0.6053 \\
0.6018 \\
0.6020 \\
0.6038 \\
0.6036 \\
0.6068 \\
0.6039 \\
0.6057 \\
0.6035 \\
0.6039 \\
0.5999 \\
0.6004 \\
0.6017 \\
0.6012 \\
0.6046 \\
0.6057\end{array}$ & $\begin{array}{l}0.6029 \\
0.6032 \\
0.6052 \\
0.6054 \\
0.6025 \\
0.6026 \\
0.6040 \\
0.6038 \\
0.6070 \\
0.6041 \\
0.6058 \\
0.6037 \\
0.6041 \\
0.6005 \\
0.6010 \\
0.6021 \\
0.6017 \\
0.6047 \\
0.6057\end{array}$ \\
\hline
\end{tabular}

Table 47. Measured and calculated quantities for 0.67 beta ratio, elbow at 170, Zanker at 160 , $f($ ange taps at position A. Pipe Diameter $=10.366 \mathrm{~cm}(4.081 \mathrm{in}), 3.8 \mu \mathrm{m}$ Orifice Diameter $=6.9840 \mathrm{~cm}(2.7496 \mathrm{in})$

\begin{tabular}{|c|c|c|c|c|c|c|c|c|}
\hline Run ID & $\begin{array}{c}\text { Pressure } \\
\text { (MPa) }\end{array}$ & $\begin{array}{c}\text { Temperature } \\
\text { (K) }\end{array}$ & $\begin{array}{l}\text { Density } \\
\left(\mathrm{kg} / \mathrm{m}^{3}\right)\end{array}$ & $\begin{array}{c}\text { Dif Press } \\
\text { (kPa) }\end{array}$ & $\begin{array}{c}\text { Flow Rate } \\
(\mathrm{kg} / \mathrm{s})\end{array}$ & $\begin{array}{c}\text { Pipe Re No. } \\
\left(/ 10^{5}\right)\end{array}$ & C & $\mathrm{Cr}_{2}$ \\
\hline $\begin{array}{l}061291-1 \\
061291-2 \\
061291-4 \\
061291-5 \\
061291-6 \\
061291-7 \\
061291-8 \\
061291-9\end{array}$ & $\begin{array}{l}3.9659 \\
3.9601 \\
3.8851 \\
3.8798 \\
3.9863 \\
3.9839 \\
3.8242 \\
3.8076\end{array}$ & $\begin{array}{l}285.31 \\
285.38 \\
284.42 \\
284.31 \\
285.58 \\
285.48 \\
285.03 \\
285.48\end{array}$ & $\begin{array}{l}47.24 \\
47.16 \\
46.43 \\
46.39 \\
47.43 \\
47.42 \\
45.59 \\
45.32\end{array}$ & $\begin{array}{l}4.185 \\
4.204 \\
6.157 \\
6.135 \\
2.695 \\
2.722 \\
7.601 \\
8.010\end{array}$ & $\begin{array}{l}1.6306 \\
1.6313 \\
1.9513 \\
1.9476 \\
1.3127 \\
1.3176 \\
2.1451 \\
2.1973\end{array}$ & $\begin{array}{l}1.1121 \\
1.1125 \\
1.3350 \\
1.3330 \\
0.8945 \\
0.8980 \\
1.4666 \\
1.5009\end{array}$ & $\begin{array}{l}0.6032 \\
0.6026 \\
0.6003 \\
0.6005 \\
0.6039 \\
0.6032 \\
0.5993 \\
0.5998\end{array}$ & $\begin{array}{l}0.6033 \\
0.6027 \\
0.6004 \\
0.6006 \\
0.6040 \\
0.6032 \\
0.5995 \\
0.6000\end{array}$ \\
\hline
\end{tabular}


Table 48. Measured and calculated quantities for 0.67 beta ratio, elbow at 170 , Zanker at 160 , $\mathrm{flange}$ taps at position $\mathrm{C}$. Pipe Diameter $=10.366 \mathrm{~cm}(4.081 \mathrm{in}), 3.8 \mu \mathrm{m}$ Orifice Diameter $=6.9840 \mathrm{~cm}(2.7496 \mathrm{in})$

\begin{tabular}{|c|c|c|c|c|c|c|c|c|}
\hline Run ID & $\begin{array}{c}\text { Pressure } \\
\text { (MPa) }\end{array}$ & $\begin{array}{c}\text { Temperature } \\
(K)\end{array}$ & $\begin{array}{l}\text { Density } \\
\left(\mathrm{kg} / \mathrm{m}^{3}\right)\end{array}$ & $\begin{array}{c}\text { Dif Press } \\
\text { (kPa) }\end{array}$ & $\begin{array}{c}\text { Flow Rate } \\
(\mathrm{kg} / \mathrm{s})\end{array}$ & $\begin{array}{c}\text { Pipe Re No. } \\
\left(/ 10^{6}\right)\end{array}$ & C & $\mathrm{Cr}_{2}$ \\
\hline $\begin{array}{l}061291-1 \\
061291-2 \\
061291-4 \\
061291-5 \\
061291-6 \\
061291-7 \\
061291-8 \\
061291-9\end{array}$ & $\begin{array}{l}3.9659 \\
3.9601 \\
3.8851 \\
3.8798 \\
3.9863 \\
3.9839 \\
3.8242 \\
3.8076\end{array}$ & $\begin{array}{l}285.31 \\
285.38 \\
284.42 \\
284.31 \\
285.58 \\
285.48 \\
285.03 \\
285.48\end{array}$ & $\begin{array}{l}47.24 \\
47.16 \\
46.43 \\
46.39 \\
47.43 \\
47.42 \\
45.59 \\
45.32\end{array}$ & $\begin{array}{l}4.174 \\
4.195 \\
6.139 \\
6.121 \\
2.688 \\
2.713 \\
7.571 \\
7.983\end{array}$ & $\begin{array}{l}1.6306 \\
1.6313 \\
1.9513 \\
1.9476 \\
1.3127 \\
1.3176 \\
2.1451 \\
2.1973\end{array}$ & $\begin{array}{l}1.1121 \\
1.1125 \\
1.3350 \\
1.3330 \\
0.8945 \\
0.8980 \\
1.4666 \\
1.5009\end{array}$ & $\begin{array}{l}0.6040 \\
0.6033 \\
0.6011 \\
0.6011 \\
0.6047 \\
0.6042 \\
0.6004 \\
0.6008\end{array}$ & $\begin{array}{l}0.6041 \\
0.6034 \\
0.6013 \\
0.6013 \\
0.6048 \\
0.6043 \\
0.6006 \\
0.6010\end{array}$ \\
\hline
\end{tabular}

Table 49. Measured and calculated quantities for 0.73 beta ratio, elbow at 170, Zanker at 160 , $f(a n g e$ taps at position A. Pipe Diameter $=10.366 \mathrm{~cm}(4.081 \mathrm{in}), 3.8 \mu \mathrm{m}$ Orifice Diameter $=7.6197 \mathrm{~cm}(2.9999 \mathrm{in})$

\begin{tabular}{|c|c|c|c|c|c|c|c|c|}
\hline Run ID & $\begin{array}{l}\text { Pressure } \\
\text { (MPa) }\end{array}$ & $\begin{array}{c}\text { Temperature } \\
(K)\end{array}$ & $\begin{array}{l}\text { Density } \\
\left(\mathrm{kg} / \mathrm{m}^{3}\right)\end{array}$ & $\begin{array}{c}\text { Dif Press } \\
\text { (kPa) }\end{array}$ & $\begin{array}{c}\text { Flow Rate } \\
(\mathrm{kg} / \mathrm{s})\end{array}$ & $\begin{array}{l}\text { Pipe Re No. } \\
\left(/ 10^{6}\right)\end{array}$ & C & $\mathrm{Cr}_{2}$ \\
\hline $\begin{array}{l}061191-1 \\
061191-2 \\
061191-3 \\
061191-4 \\
061191-5 \\
061191-6 \\
061191-7 \\
061191-8 \\
061191-9\end{array}$ & $\begin{array}{l}3.8651 \\
3.8629 \\
3.9410 \\
3.9411 \\
3.8105 \\
3.7969 \\
3.8986 \\
3.8980 \\
3.7909\end{array}$ & $\begin{array}{l}286.21 \\
286.13 \\
285.74 \\
285.79 \\
285.98 \\
285.36 \\
285.60 \\
285.71 \\
284.24\end{array}$ & $\begin{array}{l}45.88 \\
45.86 \\
46.86 \\
46.86 \\
45.26 \\
45.21 \\
46.38 \\
46.36 \\
45.33\end{array}$ & $\begin{array}{l}4.247 \\
4.196 \\
2.661 \\
2.689 \\
5.232 \\
5.144 \\
3.351 \\
3.377 \\
5.142\end{array}$ & $\begin{array}{l}2.0269 \\
2.0134 \\
1.6228 \\
1.6329 \\
2.2357 \\
2.2088 \\
1.8078 \\
1.8158 \\
2.2144\end{array}$ & $\begin{array}{l}1.3811 \\
1.3722 \\
1.1059 \\
1.1127 \\
1.5252 \\
1.5094 \\
1.2331 \\
1.2382 \\
1.5174\end{array}$ & $\begin{array}{l}0.5992 \\
0.5989 \\
0.5997 \\
0.6004 \\
0.5995 \\
0.5977 \\
0.5984 \\
0.5989 \\
0.5985\end{array}$ & $\begin{array}{l}0.5993 \\
0.5990 \\
0.5998 \\
0.6004 \\
0.5996 \\
0.5978 \\
0.5985 \\
0.5990 \\
0.5986\end{array}$ \\
\hline
\end{tabular}

Table 50. Measured and calculated quantities for 0.73 beta ratio, elbow at $170,2 a n k e r$ at 160 , flange taps at position $C$. Pipe Diameter $=10.366 \mathrm{~cm}(4.081 \mathrm{in}), 3.8 \mu \mathrm{m}$ Orifice Diameter $=7.6197 \mathrm{~cm}(2.9999 \mathrm{in})$

\begin{tabular}{|c|c|c|c|c|c|c|c|c|}
\hline Run ID & $\begin{array}{c}\text { Pressure } \\
\text { (MPa) }\end{array}$ & $\begin{array}{c}\text { Temperature } \\
\text { (K) }\end{array}$ & $\begin{array}{l}\text { Density } \\
\left(\mathrm{kg} / \mathrm{m}^{3}\right)\end{array}$ & $\begin{array}{c}\text { Dif Press } \\
\text { (kPa) }\end{array}$ & $\begin{array}{c}\text { Flow Rate } \\
(\mathrm{kg} / \mathrm{s})\end{array}$ & $\begin{array}{l}\text { Pipe Re No. } \\
\left(/ 10^{6}\right)\end{array}$ & C & $\mathrm{Cr}_{2}$ \\
\hline $\begin{array}{l}061191-1 \\
061191-2 \\
061191-3 \\
061191-4 \\
061191-5 \\
061191-6 \\
061191-7 \\
061191-8 \\
061191-9\end{array}$ & $\begin{array}{l}3.8651 \\
3.8629 \\
3.9410 \\
3.9411 \\
3.8105 \\
3.7969 \\
3.8986 \\
3.8980 \\
3.7909\end{array}$ & $\begin{array}{l}286.21 \\
286.13 \\
285.74 \\
285.79 \\
285.98 \\
285.36 \\
285.60 \\
285.71 \\
284.24\end{array}$ & $\begin{array}{l}45.88 \\
45.86 \\
46.86 \\
46.86 \\
45.26 \\
45.21 \\
46.38 \\
46.36 \\
45.33\end{array}$ & $\begin{array}{l}4.226 \\
4.177 \\
2.647 \\
2.672 \\
5.218 \\
5.120 \\
3.343 \\
3.363 \\
5.119\end{array}$ & $\begin{array}{l}2.0269 \\
2.0134 \\
1.6228 \\
1.6329 \\
2.2357 \\
2.2088 \\
1.8078 \\
1.8158 \\
2.2144\end{array}$ & $\begin{array}{l}1.3811 \\
1.3722 \\
1.1059 \\
1.1127 \\
1.5252 \\
1.5094 \\
1.2331 \\
1.2382 \\
1.5174\end{array}$ & $\begin{array}{l}0.6007 \\
0.6003 \\
0.6012 \\
0.6022 \\
0.6003 \\
0.5991 \\
0.5991 \\
0.6001 \\
0.5998\end{array}$ & $\begin{array}{l}0.6008 \\
0.6004 \\
0.6013 \\
0.6023 \\
0.6004 \\
0.5992 \\
0.5992 \\
0.6002 \\
0.6000\end{array}$ \\
\hline
\end{tabular}

Table 51. Measured and catculated quantities for 0.54 beta ratio, oversize Sprenkle at 440 , flange taps at position A.

Pipe Diameter $=5.250 \mathrm{~cm}(2.067 \mathrm{in}), 4.1 \mu \mathrm{m}$ Orifice Diameter $=2.8588 \mathrm{~cm}(1.1255 \mathrm{in})$

\begin{tabular}{|c|c|c|c|c|c|c|c|c|}
\hline Run ID & $\begin{array}{l}\text { Pressure } \\
\text { (MPa) }\end{array}$ & $\begin{array}{c}\text { Temperature } \\
\text { (K) }\end{array}$ & $\begin{array}{l}\text { Density } \\
\left(\mathrm{kg} / \mathrm{m}^{3}\right)\end{array}$ & $\begin{array}{c}\text { Dif Press } \\
\text { (kPa) }\end{array}$ & $\begin{array}{c}\text { Flow Rate } \\
(\mathrm{kg} / \mathrm{s})\end{array}$ & $\begin{array}{c}\text { Pipe Re No. } \\
\left(/ 10^{6}\right)\end{array}$ & C & $\mathrm{CY}_{2}$ \\
\hline $102291-1$ & 4.0411 & 288.49 & 47.55 & 9.902 & 0.3955 & 0.5280 & 0.6062 & 0.6065 \\
\hline $102291-2$ & 4.0408 & 288.46 & 47.56 & 9.892 & 0.3948 & 0.5271 & 0.6055 & 0.6058 \\
\hline $102299-3$ & 3.9806 & 288.07 & 46.91 & 57.814 & 0.9567 & 1.2795 & 0.6095 & 0.6113 \\
\hline $102299-4$ & 3.9776 & 288.01 & 46.89 & 58.333 & 0.9602 & 1.2844 & 0.6092 & 0.6110 \\
\hline $102291-5$ & 3.8349 & 287.46 & 45.30 & 42.171 & 0.7989 & 1.0719 & 0.6069 & 0.6083 \\
\hline $102291-6$ & 3.8357 & 287.61 & 45.28 & 41.913 & 0.7965 & 1.0683 & 0.6071 & 0.6084 \\
\hline $102291-7$ & 3.8922 & 287.96 & 45.89 & 25.402 & 0.6229 & 0.8341 & 0.6063 & 0.6071 \\
\hline $102291-9$ & 3.8088 & 287.29 & 45.02 & 59.325 & 0.9461 & 1.2703 & 0.6073 & 0.6092 \\
\hline $102291 \cdot 10$ & 3.8110 & 287.63 & 44.98 & 58.740 & 0.9420 & 1.2638 & 0.6080 & 0.6098 \\
\hline $102391-1$ & 3.8399 & 288.17 & 45.23 & 57.929 & 0.9332 & 1.2499 & 0.6048 & 0.6067 \\
\hline $102391-2$ & 3.8380 & 288.21 & 45.20 & 61.285 & 0.9610 & 1.2870 & 0.6057 & 0.6076 \\
\hline $102391-3$ & 3.8202 & 287.96 & 45.04 & 21.472 & 0.5662 & 0.7589 & 0.6052 & 0.6059 \\
\hline $102391-4$ & 3.8211 & 288.07 & 45.03 & 21.640 & 0.5685 & 0.7617 & 0.6053 & 0.6060 \\
\hline $102391-5$ & 3.7783 & 287.87 & 44.56 & 36.953 & 0.7398 & 0.9922 & 0.6055 & 0.6067 \\
\hline $102391-6$ & 3.7778 & 287.36 & 44.64 & 36.838 & 0.7394 & 0.9929 & 0.6056 & 0.6068 \\
\hline $102391-7$ & 3.8908 & 288.34 & 45.80 & 10.219 & 0.3937 & 0.5267 & 0.6052 & 0.6055 \\
\hline $102391-8$ & 3.8940 & 288.34 & 45.84 & 10.198 & 0.3936 & 0.5266 & 0.6054 & 0.6057 \\
\hline
\end{tabular}


Table 52. Measured and calculated quantities for 0.54 beta ratio, oversize Sprenkle at 440 , flange taps at position 8 .

Pipe o iameter $=5.250 \mathrm{~cm}(2.067 \mathrm{in}), 4.1 \mu \mathrm{m}$ Orifice Diameter $=2.8588 \mathrm{~cm}(1.1255 \mathrm{in})$

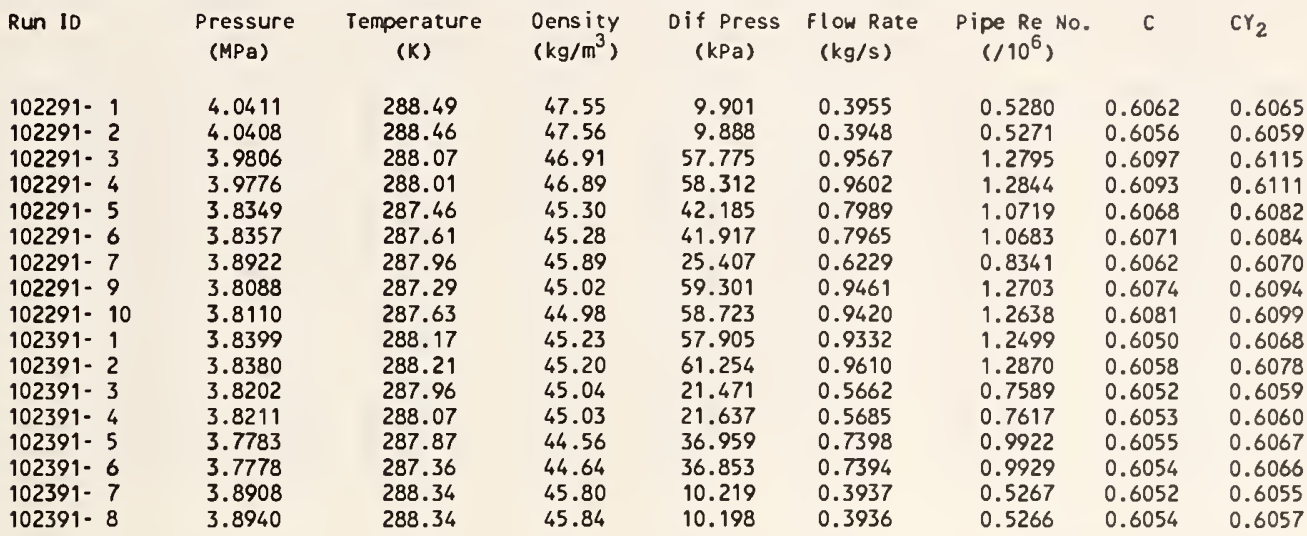

Table 53. Measured and calculated quantities for 0.54 beta ratio, oversize Sprenkle at 440 , flange taps at position $\mathrm{C}$.

Pipe 0iameter $=5.250 \mathrm{~cm}(2.067 \mathrm{in}), 4.1 \mu \mathrm{m}$ Orifice Diameter $=2.8588 \mathrm{~cm}(1.1255 \mathrm{in})$

\begin{tabular}{|c|c|c|c|c|c|c|c|c|}
\hline Run 10 & $\begin{array}{c}\text { Pressure } \\
\text { (MPa) }\end{array}$ & $\begin{array}{c}\text { Temperature } \\
\text { (K) }\end{array}$ & $\begin{array}{l}\text { Density } \\
\left(\mathrm{kg} / \mathrm{m}^{3}\right)\end{array}$ & $\begin{array}{c}\text { Dif Press } \\
\text { (kPa) }\end{array}$ & $\begin{array}{c}\text { Flow Rate } \\
(\mathrm{kg} / \mathrm{s})\end{array}$ & $\begin{array}{c}\text { Pipe Re No. } \\
\left(/ 10^{6}\right)\end{array}$ & C & $\mathrm{Cr}_{2}$ \\
\hline $\begin{array}{l}102291-1 \\
102291-2 \\
102291-3 \\
102291-4 \\
102291-5 \\
102291-6 \\
102291-7 \\
102291-9 \\
102291-10 \\
102391-1 \\
102391-2 \\
102391-3 \\
102391-4 \\
102391-5 \\
102391-6 \\
102391-7 \\
102391-8\end{array}$ & $\begin{array}{l}4.0411 \\
4.0408 \\
3.9806 \\
3.9776 \\
3.8349 \\
3.8357 \\
3.8922 \\
3.8088 \\
3.8110 \\
3.8399 \\
3.8380 \\
3.8202 \\
3.8211 \\
3.7783 \\
3.7778 \\
3.8908 \\
3.8940\end{array}$ & $\begin{array}{l}288.49 \\
288.46 \\
288.07 \\
288.01 \\
287.46 \\
287.61 \\
287.96 \\
287.29 \\
287.63 \\
288.17 \\
288.21 \\
287.96 \\
288.07 \\
287.87 \\
287.36 \\
288.34 \\
288.34\end{array}$ & $\begin{array}{l}47.55 \\
47.56 \\
46.91 \\
46.89 \\
45.30 \\
45.28 \\
45.89 \\
45.02 \\
44.98 \\
45.23 \\
45.20 \\
45.04 \\
45.03 \\
44.56 \\
44.64 \\
45.80 \\
45.84\end{array}$ & $\begin{array}{r}9.910 \\
9.900 \\
57.788 \\
58.324 \\
42.196 \\
41.925 \\
25.413 \\
59.302 \\
58.704 \\
57.868 \\
61.216 \\
21.471 \\
21.645 \\
36.965 \\
36.843 \\
10.227 \\
10.206\end{array}$ & $\begin{array}{l}0.3955 \\
0.3948 \\
0.9567 \\
0.9602 \\
0.7989 \\
0.7965 \\
0.6229 \\
0.9461 \\
0.9420 \\
0.9332 \\
0.9610 \\
0.5662 \\
0.5685 \\
0.7398 \\
0.7394 \\
0.3937 \\
0.3936\end{array}$ & $\begin{array}{l}0.5280 \\
0.5271 \\
1.2795 \\
1.2844 \\
1.0719 \\
1.0683 \\
0.8341 \\
1.2703 \\
1.2638 \\
1.2499 \\
1.2870 \\
0.7589 \\
0.7617 \\
0.9922 \\
0.9929 \\
0.5267 \\
0.5266\end{array}$ & $\begin{array}{l}0.6060 \\
0.6052 \\
0.6097 \\
0.6092 \\
0.6068 \\
0.6070 \\
0.6062 \\
0.6074 \\
0.6081 \\
0.6051 \\
0.6060 \\
0.6053 \\
0.6052 \\
0.6054 \\
0.6055 \\
0.6049 \\
0.6052\end{array}$ & $\begin{array}{l}0.6063 \\
0.6055 \\
0.6115 \\
0.6110 \\
0.6081 \\
0.6083 \\
0.6070 \\
0.6093 \\
0.6100 \\
0.6070 \\
0.6079 \\
0.6059 \\
0.6059 \\
0.6066 \\
0.6067 \\
0.6053 \\
0.6055\end{array}$ \\
\hline
\end{tabular}

Table 54. Measured and calculated quantities for 0.54 beta ratio, oversize Sprenkle at 440 , flange taps at position 0 .

Pipe Diameter $=5.250 \mathrm{~cm}(2.067 \mathrm{in}), 4.1 \mu \mathrm{m}$ Orifice Diameter $=2.8588 \mathrm{~cm}(1.1255 \mathrm{in})$

\begin{tabular}{|c|c|c|c|c|c|c|c|c|}
\hline Run 10 & $\begin{array}{c}\text { Pressure } \\
\text { (MPa) }\end{array}$ & $\begin{array}{c}\text { Temperature } \\
\text { (K) }\end{array}$ & $\begin{array}{l}\text { Density } \\
\left(\mathrm{kg} / \mathrm{m}^{3}\right)\end{array}$ & $\begin{array}{l}\text { Dif Press } \\
\text { (KPa) }\end{array}$ & $\begin{array}{c}\text { Flow Rate } \\
(\mathrm{kg} / \mathrm{s})\end{array}$ & $\begin{array}{c}\text { Pipe Re No. } \\
\left(/ 10^{6}\right)\end{array}$ & c & $\mathrm{Cr}_{2}$ \\
\hline $102291-1$ & 4.0411 & 288.49 & 47.55 & 9.917 & 0.3955 & 0.5280 & 0.6057 & 0.6060 \\
\hline $102291-2$ & 4.0408 & 288.46 & 47.56 & 9.908 & 0.3948 & 0.5271 & 0.6050 & 0.6053 \\
\hline $102291-3$ & 3.9806 & 288.07 & 46.91 & 57.818 & 0.9567 & 1.2795 & 0.6095 & 0.6113 \\
\hline $102291-4$ & 3.9776 & 288.01 & 46.89 & 58.354 & 0.9602 & 1.2844 & 0.6091 & 0.6109 \\
\hline $102291-5$ & 3.8349 & 287.46 & 45.30 & 42.224 & 0.7989 & 1.0719 & 0.6066 & 0.6079 \\
\hline $102291-6$ & 3.8357 & 287.61 & 45.28 & 41.953 & 0.7965 & 1.0683 & 0.6068 & 0.6081 \\
\hline $102291 \cdot 7$ & 3.8922 & 287.96 & 45.89 & 25.432 & 0.6229 & 0.8341 & 0.6059 & 0.6067 \\
\hline $102291-9$ & 3.8088 & 287.29 & 45.02 & 59.346 & 0.9461 & 1.2703 & 0.6072 & 0.6091 \\
\hline $102291-10$ & 3.8110 & 287.63 & 44.98 & 58.750 & 0.9420 & 1.2638 & 0.6079 & 0.6098 \\
\hline $102391-1$ & 3.8399 & 288.17 & 45.23 & 57.918 & 0.9332 & 1.2499 & 0.6049 & 0.6067 \\
\hline $102391-2$ & 3.8380 & 288.21 & 45.20 & 61.279 & 0.9610 & 1.2870 & 0.6057 & 0.6076 \\
\hline $102391-3$ & 3.8202 & 287.96 & 45.04 & 21.491 & 0.5662 & 0.7589 & 0.6050 & 0.6057 \\
\hline $102391-4$ & 3.8211 & 288.07 & 45.03 & 21.660 & 0.5685 & 0.7617 & 0.6050 & 0.6057 \\
\hline $102391-5$ & 3.7783 & 287.87 & 44.56 & 36.988 & 0.7398 & 0.9922 & 0.6052 & 0.6064 \\
\hline $102391-6$ & 3.7778 & 287.36 & 44.64 & 36.877 & 0.7394 & 0.9929 & 0.6052 & 0.6064 \\
\hline $102391-7$ & 3.8908 & 288.34 & 45.80 & 10.232 & 0.3937 & 0.5267 & 0.6048 & 0.6051 \\
\hline $102391-8$ & 3.8940 & 288.34 & 45.84 & 10.210 & 0.3936 & 0.5266 & 0.6051 & 0.6054 \\
\hline
\end{tabular}


Table 55. Measured and calculated quantities for 0.67 beta ratio, oversize Sprenkle at 44D, flange taps at position A. Pipe Diameter $=5.250 \mathrm{~cm}(2.067 \mathrm{in}), 4.1 \mu \mathrm{m}$ Orifice Diameter $=3.4933 \mathrm{~cm}(1.3753 \mathrm{in})$

\begin{tabular}{|c|c|c|c|c|c|c|c|c|}
\hline Run ID & $\begin{array}{c}\text { Pressure } \\
\text { (MPa) }\end{array}$ & $\begin{array}{c}\text { Temperature } \\
\text { (K) }\end{array}$ & $\begin{array}{l}\text { Density } \\
\left(\mathrm{kg} / \mathrm{m}^{3}\right)\end{array}$ & $\begin{array}{c}\text { Dif Press } \\
\text { ( } \mathrm{kPa})\end{array}$ & $\begin{array}{c}\text { Flow Rate } \\
(\mathrm{kg} / \mathrm{s})\end{array}$ & $\begin{array}{c}\text { Pipe Re No. } \\
\left(/ 10^{6}\right)\end{array}$ & C & $\mathrm{CY}_{2}$ \\
\hline $102291-1$ & 4.0092 & 288.08 & 47.25 & 26.154 & 1.0296 & 1.3764 & 0.6121 & 0.6128 \\
\hline $102291-2$ & 4.0107 & 288.44 & 47.20 & 26.124 & 1.0279 & 1.3729 & 0.6118 & 0.6125 \\
\hline $102291-3$ & 3.9643 & 287.64 & 46.80 & 41.964 & 1.2958 & 1.7351 & 0.6107 & 0.6118 \\
\hline $102291-4$ & 3.9550 & 287.43 & 46.73 & 41.820 & 1.2949 & 1.7350 & 0.6118 & 0.6130 \\
\hline $102291-5$ & 3.9851 & 287.89 & 47.00 & 8.767 & 0.5903 & 0.7898 & 0.6083 & 0.6085 \\
\hline $102291-6$ & 3.9861 & 288.10 & 46.97 & 8.802 & 0.5925 & 0.7922 & 0.6094 & 0.6096 \\
\hline $102291-7$ & 3.9008 & 287.76 & 46.02 & 58.379 & 1.5125 & 2.0262 & 0.6089 & 0.6105 \\
\hline $102291-8$ & 3.9037 & 287.47 & 46.11 & 57.784 & 1.5088 & 2.0226 & 0.6100 & 0.6116 \\
\hline $102391-1$ & 3.8741 & 288.10 & 45.65 & 8.706 & 0.5797 & 0.7762 & 0.6082 & 0.6084 \\
\hline $102391-2$ & 3.8741 & 288.21 & 45.63 & 8.683 & 0.5790 & 0.7751 & 0.6084 & 0.6086 \\
\hline $102391-3$ & 3.8386 & 287.61 & 45.31 & 36.721 & 1.1933 & 1.6004 & 0.6111 & 0.6121 \\
\hline $102391-4$ & 3.8411 & 288.02 & 45.27 & 36.148 & 1.1831 & 1.5851 & 0.6109 & 0.6119 \\
\hline $102391-5$ & 3.8202 & 287.66 & 45.09 & 18.329 & 0.8373 & 1.1230 & 0.6089 & 0.6094 \\
\hline $102391-6$ & 3.8200 & 287.37 & 45.14 & 18.391 & 0.8385 & 1.1255 & 0.6085 & 0.6090 \\
\hline $102391-7$ & 3.7803 & 287.77 & 44.60 & 57.248 & 1.4757 & 1.9798 & 0.6095 & 0.6111 \\
\hline $102391-8$ & 3.7858 & 287.42 & 44.72 & 56.793 & 1.4715 & 1.9757 & 0.6094 & 0.6110 \\
\hline
\end{tabular}

Table 56. Measured and calculated quantities for 0.67 beta ratio, oversize Sprenkle at 440 , $f(a n g e$ taps at position $B$. Pipe Diameter $=5.250 \mathrm{~cm}(2.067 \mathrm{in}), 4.1 \mu \mathrm{m}$ Orifice Diameter $=3.4933 \mathrm{~cm}(1.3753 \mathrm{in})$

\begin{tabular}{|c|c|c|c|c|c|c|c|c|}
\hline Run ID & $\begin{array}{l}\text { Pressure } \\
\text { (MPa) }\end{array}$ & $\begin{array}{c}\text { Temperature } \\
\text { (K) }\end{array}$ & $\begin{array}{l}\text { Density } \\
\left(\mathrm{kg} / \mathrm{m}^{3}\right)\end{array}$ & $\begin{array}{l}\text { Dif Press } \\
\quad(\mathrm{KPa})\end{array}$ & $\begin{array}{c}\text { Flow Rate } \\
(\mathrm{kg} / \mathrm{s})\end{array}$ & $\begin{array}{l}\text { Pipe Re No. } \\
\left(/ 10^{6}\right)\end{array}$ & C & $\mathrm{CY}_{2}$ \\
\hline 102291- 1 & 4.0092 & 288.08 & 47.25 & 26.156 & 1.0296 & 1.3764 & 0.6121 & 0.6128 \\
\hline $102291-2$ & 4.0107 & 288.44 & 47.20 & 26.127 & 1.0279 & 1.3729 & 0.6117 & 0.6124 \\
\hline $102291-3$ & 3.9643 & 287.64 & 46.80 & 41.955 & 1.2958 & 1.7351 & 0.6108 & 0.6119 \\
\hline $102291-4$ & 3.9550 & 287.43 & 46.73 & 41.838 & 1.2949 & 1.7350 & 0.6117 & 0.6128 \\
\hline $102291-5$ & 3.9851 & 287.89 & 47.00 & 8.762 & 0.5903 & 0.7898 & 0.6085 & 0.6087 \\
\hline $102291 \cdot 6$ & 3.9861 & 288.10 & 46.97 & 8.795 & 0.5925 & 0.7922 & 0.6097 & 0.6099 \\
\hline $102291-7$ & 3.9008 & 287.76 & 46.02 & 58.352 & 1.5125 & 2.0262 & 0.6091 & 0.6107 \\
\hline $102291-8$ & 3.9037 & 287.47 & 46.11 & 57.765 & 1.5088 & 2.0226 & 0.6101 & 0.6117 \\
\hline $102391-1$ & 3.8741 & 288.10 & 45.65 & 8.678 & 0.5797 & 0.7762 & 0.6092 & 0.6094 \\
\hline $102391-2$ & 3.8741 & 288.21 & 45.63 & 8.657 & 0.5790 & 0.7751 & 0.6093 & 0.6096 \\
\hline $102391-3$ & 3.8386 & 287.61 & 45.31 & 36.646 & 1.1933 & 1.6004 & 0.6117 & 0.6127 \\
\hline $102391-4$ & 3.8411 & 288.02 & 45.27 & 36.085 & 1.1831 & 1.5851 & 0.6115 & 0.6125 \\
\hline $102391-5$ & 3.8202 & 287.66 & 45.09 & 18.289 & 0.8373 & 1.1230 & 0.6096 & 0.6101 \\
\hline $102391-6$ & 3.8200 & 287.37 & 45.14 & 18.345 & 0.8385 & 1.1255 & 0.6092 & 0.6098 \\
\hline $102391-7$ & 3.7803 & 287.77 & 44.60 & 57.105 & 1.4757 & 1.9798 & 0.6103 & 0.6119 \\
\hline $102391-8$ & 3.7858 & 287.42 & 44.72 & 56.667 & 1.4715 & 1.9757 & 0.6100 & 0.6116 \\
\hline
\end{tabular}

Table 57. Measured and calculated quantities for 0.67 beta ratio, oversize Sprenkle at $44 \mathrm{D}$, flange taps at position C.

Pipe Diameter $=5.250 \mathrm{~cm}(2.067 \mathrm{in}), 4.1 \mu \mathrm{m}$ Orifice Diameter $=3.4933 \mathrm{~cm}(1.3753 \mathrm{in})$

\begin{tabular}{|c|c|c|c|c|c|c|c|c|}
\hline Run ID & $\begin{array}{c}\text { Pressure } \\
\text { (MPa) }\end{array}$ & $\begin{array}{c}\text { Tempera ture } \\
\text { (K) }\end{array}$ & $\begin{array}{l}\text { Density } \\
\left(\mathrm{kg} / \mathrm{m}^{3}\right)\end{array}$ & $\begin{array}{c}\text { Dif Press } \\
\text { (kPa) }\end{array}$ & $\begin{array}{c}\text { Flow Rate } \\
(\mathrm{kg} / \mathrm{s})\end{array}$ & $\begin{array}{c}\text { Pipe Re No. } \\
\left(/ 10^{6}\right)\end{array}$ & C & $\mathrm{Cr}_{2}$ \\
\hline $102291-1$ & 4.0092 & 288.08 & 47.25 & 26.181 & 1.0296 & 1.3764 & 0.6118 & 0.6125 \\
\hline $102291-2$ & 4.0107 & 288.44 & 47.20 & 26.150 & 1.0279 & 1.3729 & 0.6115 & 0.6122 \\
\hline $102291 \cdot 3$ & 3.9643 & 287.64 & 46.80 & 42.007 & 1.2958 & 1.7351 & 0.6104 & 0.6115 \\
\hline $102291-4$ & 3.9550 & 287.43 & 46.73 & 41.866 & 1.2949 & 1.7350 & 0.6115 & 0.6126 \\
\hline $102291-5$ & 3.9851 & 287.89 & 47.00 & 8.781 & 0.5903 & 0.7898 & 0.6078 & 0.6080 \\
\hline $102291-6$ & 3.9861 & 288.10 & 46.97 & 8.816 & 0.5925 & 0.7922 & 0.6089 & 0.6092 \\
\hline $102291-7$ & 3.9008 & 287.76 & 46.02 & 58.377 & 1.5125 & 2.0262 & 0.6090 & 0.6106 \\
\hline $102291-8$ & 3.9037 & 287.47 & 46.11 & 57.784 & 1.5088 & 2.0226 & 0.6100 & 0.6116 \\
\hline $102391-1$ & 3.8741 & 288.10 & 45.65 & 8.701 & 0.5797 & 0.7762 & 0.6083 & 0.6086 \\
\hline $102391-2$ & 3.8741 & 288.21 & 45.63 & 8.679 & 0.5790 & 0.7751 & 0.6085 & 0.6088 \\
\hline $102391-3$ & 3.8386 & 287.61 & 45.31 & 36.674 & 1.1933 & 1.6004 & 0.6115 & 0.6125 \\
\hline $102391-4$ & 3.8411 & 288.02 & 45.27 & 36.120 & 1.1831 & 1.5851 & 0.6112 & 0.6122 \\
\hline $102391-5$ & 3.8202 & 287.66 & 45.09 & 18.307 & 0.8373 & 1.1230 & 0.6093 & 0.6098 \\
\hline $102391-6$ & 3.8200 & 287.37 & 45.14 & 18.374 & 0.8385 & 1.1255 & 0.6088 & 0.6093 \\
\hline $102391-7$ & 3.7803 & 287.77 & 44.60 & 57.125 & 1.4757 & 1.9798 & 0.6102 & 0.6118 \\
\hline $102391-8$ & 3.7858 & 287.42 & 44.72 & 56.696 & 1.4715 & 1.9757 & 0.6099 & 0.6115 \\
\hline
\end{tabular}


Table 58. Measured and calculated quantities for 0.67 beta ratio, oversize Sprenkle at 440 , $f l a n g e t a p s$ at position $D$.

Pipe Diameter $=5.250 \mathrm{~cm}(2.067 \mathrm{in}), 4.1 \mu \mathrm{m}$ Orifice Diameter $=3.4933 \mathrm{~cm}(1.3753 \mathrm{in})$

\begin{tabular}{|c|c|c|c|c|c|c|c|c|}
\hline Run ID & $\begin{array}{c}\text { Pressure } \\
\text { (MPa) }\end{array}$ & $\begin{array}{c}\text { Temperature } \\
(K)\end{array}$ & $\begin{array}{l}\text { Density } \\
\left(\mathrm{kg} / \mathrm{m}^{3}\right)\end{array}$ & $\begin{array}{c}\text { Dif Press } \\
\text { (kPa) }\end{array}$ & $\begin{array}{c}\text { Flow Rate } \\
(\mathrm{kg} / \mathrm{s})\end{array}$ & $\begin{array}{c}\text { Pipe Re No. } \\
\left(/ 10^{5}\right)\end{array}$ & C & $\mathrm{CY}_{2}$ \\
\hline 102291- 1 & 4.0092 & 288.08 & 47.25 & 26.216 & 1.0296 & 1.3764 & 0.6114 & 0.6121 \\
\hline $102291-2$ & 4.0107 & 288.44 & 47.20 & 26.189 & 1.0279 & 1.3729 & 0.6110 & 0.6117 \\
\hline $102291-3$ & 3.9643 & 287.64 & 46.80 & 42.046 & 1.2958 & 1.7351 & 0.6101 & 0.6112 \\
\hline $102291-4$ & 3.9550 & 287.43 & 46.73 & 41.905 & 1.2949 & 1.7350 & 0.6112 & 0.6123 \\
\hline $102291-5$ & 3.9851 & 287.89 & 47.00 & 8.790 & 0.5903 & 0.7898 & 0.6075 & 0.6077 \\
\hline $102291-6$ & 3.9861 & 288.10 & 46.97 & 8.827 & 0.5925 & 0.7922 & 0.6086 & 0.6088 \\
\hline $102291-7$ & 3.9008 & 287.76 & 46.02 & 58.415 & 1.5125 & 2.0262 & 0.6088 & 0.6104 \\
\hline $102291-8$ & 3.9037 & 287.47 & 46.11 & 57.816 & 1.5088 & 2.0226 & 0.6098 & 0.6114 \\
\hline $102391-1$ & 3.8741 & 288.10 & 45.65 & 8.732 & 0.5797 & 0.7762 & 0.6073 & 0.6075 \\
\hline $102391-2$ & 3.8741 & 288.21 & 45.63 & 8.712 & 0.5790 & 0.7751 & 0.6074 & 0.6076 \\
\hline $102391-3$ & 3.8386 & 287.61 & 45.31 & 36.803 & 1.1933 & 1.6004 & 0.6104 & 0.6114 \\
\hline $102391-4$ & 3.8411 & 288.02 & 45.27 & 36.231 & 1.1831 & 1.5851 & 0.6102 & 0.6112 \\
\hline $102391-5$ & 3.8202 & 287.66 & 45.09 & 18.372 & 0.8373 & 1.1230 & 0.6082 & 0.6087 \\
\hline $102391-6$ & 3.8200 & 287.37 & 45.14 & 18.442 & 0.8385 & 1.1255 & 0.6076 & 0.6082 \\
\hline $102391-7$ & 3.7803 & 287.77 & 44.60 & 57.329 & 1.4757 & 1.9798 & 0.6091 & 0.6107 \\
\hline $102391-8$ & 3.7858 & 287.42 & 44.72 & 56.879 & 1.4715 & 1.9757 & 0.6089 & 0.6105 \\
\hline
\end{tabular}

Table 59. Measured and calculated quantities for 0.54 beta ratio plate, elbow at 17D, IT3 at 12D, flange taps at position A.

Pipe Diameter $=5.250 \mathrm{~cm}(2.067 \mathrm{in}), 4.1 \mu \mathrm{m}$ Orifice Diameter $=2.8588 \mathrm{~cm}(1.1255 \mathrm{in})$

\begin{tabular}{|c|c|c|c|c|c|c|c|c|}
\hline Run 10 & $\begin{array}{c}\text { Pressure } \\
\text { (MPa) }\end{array}$ & $\begin{array}{c}\text { Temperature } \\
(K)\end{array}$ & $\begin{array}{l}\text { Density } \\
\left(\mathrm{kg} / \mathrm{m}^{3}\right)\end{array}$ & $\begin{array}{c}\text { Dif Press } \\
\text { (kPa) }\end{array}$ & $\begin{array}{l}\text { Flow Rate } \\
(\mathrm{kg} / \mathrm{s})\end{array}$ & $\begin{array}{c}\text { Pipe Re No. } \\
\left(/ 10^{6}\right)\end{array}$ & C & $\mathrm{Cr}_{2}$ \\
\hline $\begin{array}{l}102491-1 \\
102591-1 \\
102591-2 \\
102591-3 \\
102591-4 \\
102591-5 \\
102591-6 \\
102591-7 \\
102591-1 \\
102591-2 \\
102591-3 \\
102591-4 \\
102591-5 \\
102591-6 \\
102591-7 \\
102591-8\end{array}$ & $\begin{array}{l}3.9350 \\
3.9477 \\
3.8904 \\
3.8904 \\
3.9546 \\
3.9542 \\
3.9357 \\
3.9352 \\
3.9145 \\
3.9135 \\
3.8688 \\
3.8697 \\
3.9648 \\
3.9657 \\
3.9101 \\
3.9092\end{array}$ & $\begin{array}{l}288.14 \\
288.22 \\
287.26 \\
287.77 \\
287.81 \\
287.93 \\
287.91 \\
287.65 \\
287.44 \\
287.49 \\
287.87 \\
287.61 \\
287.88 \\
287.91 \\
287.64 \\
287.59\end{array}$ & $\begin{array}{l}46.36 \\
46.50 \\
45.99 \\
45.90 \\
46.65 \\
46.63 \\
46.41 \\
46.45 \\
46.24 \\
46.22 \\
45.63 \\
45.68 \\
46.76 \\
46.77 \\
46.16 \\
46.15\end{array}$ & $\begin{array}{r}59.145 \\
59.985 \\
36.137 \\
36.213 \\
9.921 \\
10.018 \\
21.463 \\
21.482 \\
21.428 \\
21.527 \\
35.913 \\
35.630 \\
10.276 \\
10.348 \\
61.584 \\
60.250\end{array}$ & $\begin{array}{l}0.9580 \\
0.9637 \\
0.7427 \\
0.7428 \\
0.3912 \\
0.3929 \\
0.5745 \\
0.5750 \\
0.5726 \\
0.5736 \\
0.7372 \\
0.7348 \\
0.3987 \\
0.3998 \\
0.9777 \\
0.9671\end{array}$ & $\begin{array}{l}1.2816 \\
1.2889 \\
0.9963 \\
0.9952 \\
0.5236 \\
0.5257 \\
0.7690 \\
0.7701 \\
0.7675 \\
0.7689 \\
0.9878 \\
0.9851 \\
0.5336 \\
0.5350 \\
1.3100 \\
1.2960\end{array}$ & $\begin{array}{l}0.6069 \\
0.6054 \\
0.6051 \\
0.6051 \\
0.6047 \\
0.6046 \\
0.6050 \\
0.6050 \\
0.6046 \\
0.6045 \\
0.6049 \\
0.6049 \\
0.6050 \\
0.6045 \\
0.6084 \\
0.6084\end{array}$ & $\begin{array}{l}0.6088 \\
0.6072 \\
0.6062 \\
0.6062 \\
0.6050 \\
0.6049 \\
0.6057 \\
0.6057 \\
0.6053 \\
0.6052 \\
0.6060 \\
0.6061 \\
0.6053 \\
0.6049 \\
0.6103 \\
0.6103\end{array}$ \\
\hline
\end{tabular}

Table 60. Measured and calculated quantities for 0.54 beta ratio plate, elbow at 170,113 at $120, f l a n g e$ taps at position $B$.

Pipe Diameter $=5.250 \mathrm{~cm}(2.067 \mathrm{in}), 4.1 \mu \mathrm{m}$ orifice Diameter $=2.8588 \mathrm{~cm}(1.1255 \mathrm{in})$

\begin{tabular}{|c|c|c|c|c|c|c|c|c|}
\hline Run ID & $\begin{array}{c}\text { Pressure } \\
\text { (MPa) }\end{array}$ & $\begin{array}{c}\text { Temperature } \\
\text { (K) }\end{array}$ & $\begin{array}{l}\text { Density } \\
\left(\mathrm{kg} / \mathrm{m}^{3}\right)\end{array}$ & $\begin{array}{c}\text { Dif Press } \\
(\mathrm{KPa})\end{array}$ & $\begin{array}{c}\text { Flow Rate } \\
(\mathrm{kg} / \mathrm{s})\end{array}$ & $\begin{array}{c}\text { Pipe Re No. } \\
\left(/ 10^{6}\right)\end{array}$ & C & $\mathrm{CY}_{2}$ \\
\hline $102491-1$ & 3.9350 & 288.14 & 46.36 & 59.135 & 0.9580 & 1.2816 & 0.6070 & 0.6088 \\
\hline 102591- 1 & 3.9477 & 288.22 & 46.50 & 60.023 & 0.9637 & 1.2889 & 0.6052 & 0.6070 \\
\hline $102591-2$ & 3.8904 & 287.26 & 45.99 & 36.168 & 0.7427 & 0.9963 & 0.6048 & 0.6060 \\
\hline $102591-3$ & 3.8904 & 287.77 & 45.90 & 36.244 & 0.7428 & 0.9952 & 0.6049 & 0.6060 \\
\hline $102591-4$ & 3.9546 & 287.81 & 46.65 & 9.923 & 0.3912 & 0.5236 & 0.6046 & 0.6050 \\
\hline $102591-5$ & 3.9542 & 287.93 & 46.63 & 10.023 & 0.3929 & 0.5257 & 0.6044 & 0.6047 \\
\hline $102591-6$ & 3.9357 & 287.91 & 46.41 & 21.474 & 0.5745 & 0.7690 & 0.6049 & 0.6055 \\
\hline $102591-7$ & 3.9352 & 287.65 & 46.45 & 21.492 & 0.5750 & 0.7701 & 0.6049 & 0.6055 \\
\hline $102591-1$ & 3.9145 & 287.44 & 46.24 & 21.438 & 0.5726 & 0.7675 & 0.6045 & 0.6051 \\
\hline $102591-2$ & 3.9135 & 287.49 & 46.22 & 21.527 & 0.5736 & 0.7689 & 0.6045 & 0.6052 \\
\hline $102591-3$ & 3.8688 & 287.87 & 45.63 & 35.937 & 0.7372 & 0.9878 & 0.6047 & 0.6058 \\
\hline $102591-4$ & 3.8697 & 287.61 & 45.68 & 35.653 & 0.7348 & 0.9851 & 0.6047 & 0.6059 \\
\hline $102591-5$ & 3.9648 & 287.88 & 46.76 & 10.279 & 0.3987 & 0.5336 & 0.6049 & 0.6052 \\
\hline $102591-6$ & 3.9657 & 287.91 & 46.77 & 10.351 & 0.3998 & 0.5350 & 0.6044 & 0.6048 \\
\hline $102591-7$ & 3.9101 & 287.64 & 46.16 & 61.614 & 0.9777 & 1.3100 & 0.6082 & 0.6101 \\
\hline $102591-8$ & 3.9092 & 287.59 & 46.15 & 60.267 & 0.9671 & 1.2960 & 0.6083 & 0.6102 \\
\hline
\end{tabular}


Table 61. Measured and calculated quantities for 0.54 beta ratio plate, elbow at $17 \mathrm{D}$, IT3 at 120 , flange taps at position C. Pipe Diameter $=5.250 \mathrm{~cm}(2.067 \mathrm{in}), 4.1 \mu \mathrm{m}$ Orifice Diameter $=2.8588 \mathrm{~cm}(1.1255 \mathrm{in})$

\begin{tabular}{|c|c|c|c|c|c|c|c|c|}
\hline Run ID & $\begin{array}{l}\text { Pressure } \\
\text { (MPa) }\end{array}$ & $\begin{array}{c}\text { Temperature } \\
\text { (K) }\end{array}$ & $\begin{array}{l}\text { Density } \\
\left(\mathrm{kg} / \mathrm{m}^{3}\right)\end{array}$ & $\begin{array}{l}\text { Dif Press } \\
\text { (kPa) }\end{array}$ & $\begin{array}{c}\text { Flow Rate } \\
(\mathrm{kg} / \mathrm{s})\end{array}$ & $\begin{array}{c}\text { Pipe Re No. } \\
\left(/ 10^{6}\right)\end{array}$ & C & $\mathrm{CY}_{2}$ \\
\hline 102491- 1 & 3.9350 & 288.14 & 46.36 & 59.177 & 0.9580 & 1.2816 & 0.6068 & 0.6086 \\
\hline $102591-1$ & 3.9477 & 288.22 & 46.50 & 60.025 & 0.9637 & 1.2889 & 0.6052 & 0.6070 \\
\hline $102591-2$ & 3.8904 & 287.26 & 45.99 & 36.195 & 0.7427 & 0.9963 & 0.6046 & 0.6057 \\
\hline $102591-3$ & 3.8904 & 287.77 & 45.90 & 36.263 & 0.7428 & 0.9952 & 0.6047 & 0.6058 \\
\hline $102591-4$ & 3.9546 & 287.81 & 46.65 & 9.930 & 0.3912 & 0.5236 & 0.6045 & 0.6048 \\
\hline $102591=5$ & 3.9542 & 287.93 & 46.63 & 10.029 & 0.3929 & 0.5257 & 0.6043 & 0.6046 \\
\hline $102591-6$ & 3.9357 & 287.91 & 46.41 & 21.494 & 0.5745 & 0.7690 & 0.6046 & 0.6052 \\
\hline $102591-7$ & 3.9352 & 287.65 & 46.45 & 21.508 & 0.5750 & 0.7701 & 0.6047 & 0.6053 \\
\hline $102591-1$ & 3.9145 & 287.44 & 46.24 & 21.465 & 0.5726 & 0.7675 & 0.6041 & 0.6047 \\
\hline $102591-2$ & 3.9135 & 287.49 & 46.22 & 21.549 & 0.5736 & 0.7689 & 0.6042 & 0.6049 \\
\hline $102591-3$ & 3.8688 & 287.87 & 45.63 & 35.972 & 0.7372 & 0.9878 & 0.6044 & 0.6055 \\
\hline $102591-4$ & 3.8697 & 287.61 & 45.68 & 35.698 & 0.7348 & 0.9851 & 0.6044 & 0.6055 \\
\hline $102591-5$ & 3.9648 & 287.88 & 46.76 & 10.284 & 0.3987 & 0.5336 & 0.6047 & 0.6050 \\
\hline $102591-6$ & 3.9657 & 287.91 & 46.77 & 10.357 & 0.3998 & 0.5350 & 0.6043 & 0.6046 \\
\hline $102591 \cdot 7$ & 3.9101 & 287.64 & 46.16 & 61.622 & 0.9777 & 1.3100 & 0.6082 & 0.6101 \\
\hline $102591-8$ & 3.9092 & 287.59 & 46.15 & 60.304 & 0.9671 & 1.2960 & 0.6082 & 0.6100 \\
\hline
\end{tabular}

Table 62. Measured and calculated quantities for 0.54 beta ratio plate, elbow at $17 \mathrm{D}, \mathrm{IT3}$ at 120 , flange taps at position $\mathrm{D}$. Pipe Diameter $=5.250 \mathrm{~cm}(2.067 \mathrm{in}), 4.1 \mu \mathrm{m}$ Orifice Diameter $=2.8588 \mathrm{~cm}(1.1255 \mathrm{in})$

\begin{tabular}{|c|c|c|c|c|c|c|c|c|}
\hline Run ID & $\begin{array}{c}\text { Pressure } \\
\text { (MPa) }\end{array}$ & $\begin{array}{c}\text { Temperature } \\
\text { (K) }\end{array}$ & $\begin{array}{l}\text { Density } \\
\left(\mathrm{kg} / \mathrm{m}^{3}\right)\end{array}$ & $\begin{array}{c}\text { Dif Press } \\
\text { (kPa) }\end{array}$ & $\begin{array}{c}\text { Flow Rate } \\
(\mathrm{kg} / \mathrm{s})\end{array}$ & $\begin{array}{c}\text { Pipe Re No. } \\
\left(/ 10^{6}\right)\end{array}$ & C & $\mathrm{CY}_{2}$ \\
\hline $102491-1$ & 3.9350 & 288.14 & 46.36 & 59.223 & 0.9580 & 1.2816 & 0.6065 & 0.6084 \\
\hline $102591-1$ & 3.9477 & 288.22 & 46.50 & 60.086 & 0.9637 & 1.2889 & 0.6049 & 0.6067 \\
\hline $102591-2$ & 3.8904 & 287.26 & 45.99 & 36.228 & 0.7427 & 0.9963 & 0.6043 & 0.6055 \\
\hline $102591-3$ & 3.8904 & 287.77 & 45.90 & 36.312 & 0.7428 & 0.9952 & 0.6043 & 0.6054 \\
\hline $102591-4$ & 3.9546 & 287.81 & 46.65 & 9.940 & 0.3912 & 0.5236 & 0.6041 & 0.6044 \\
\hline $102591-5$ & 3.9542 & 287.93 & 46.63 & 10.038 & 0.3929 & 0.5257 & 0.6040 & 0.6043 \\
\hline $102591-6$ & 3.9357 & 287.91 & 46.41 & 21.519 & 0.5745 & 0.7690 & 0.6042 & 0.6049 \\
\hline $102591-7$ & 3.9352 & 287.65 & 46.45 & 21.542 & 0.5750 & 0.7701 & 0.6042 & 0.6048 \\
\hline 102591- 1 & 3.9145 & 287.44 & 46.24 & 21.485 & 0.5726 & 0.7675 & 0.6038 & 0.6045 \\
\hline $102591-2$ & 3.9135 & 287.49 & 46.22 & 21.575 & 0.5736 & 0.7689 & 0.6038 & 0.6045 \\
\hline $102591-3$ & 3.8688 & 287.87 & 45.63 & 36.001 & 0.7372 & 0.9878 & 0.6042 & 0.6053 \\
\hline $102591 \cdot 4$ & 3.8697 & 287.61 & 45.68 & 35.715 & 0.7348 & 0.9851 & 0.6042 & 0.6053 \\
\hline $102591-5$ & 3.9648 & 287.88 & 46.76 & 10.295 & 0.3987 & 0.5336 & 0.6044 & 0.6047 \\
\hline $102591-6$ & 3.9657 & 287.91 & 46.77 & 10.366 & 0.3998 & 0.5350 & 0.6040 & 0.6043 \\
\hline $102591-7$ & 3.9101 & 287.64 & 46.16 & 61.676 & 0.9777 & 1.3100 & 0.6079 & 0.6098 \\
\hline $102591-8$ & 3.9092 & 287.59 & 46.15 & 60.354 & 0.9671 & 1.2960 & 0.6079 & 0.6098 \\
\hline
\end{tabular}

Table 63. Measured and calculated quantities for 0.67 beta ratio plate, elbow at $170, I T 3$ at $120, f l a n g e$ taps at position A. Pipe Diameter $=5.250 \mathrm{~cm}(2.067 \mathrm{in}), 4.1 \mu \mathrm{m}$ Orifice Diameter $=3.4933 \mathrm{~cm}(1.3753 \mathrm{in})$

$\begin{array}{lcccccccc}\text { Run ID } & \begin{array}{c}\text { Pressure } \\ \text { (MPa) }\end{array} & \begin{array}{c}\text { Temperature } \\ (\mathrm{K})\end{array} & \begin{array}{c}\text { Density } \\ \left(\mathrm{kg} / \mathrm{m}^{3}\right)\end{array} & \begin{array}{c}\text { Dif Press } \\ (\mathrm{kPa})\end{array} & \begin{array}{c}\text { Flow Rate } \\ (\mathrm{kg} / \mathrm{s})\end{array} & \begin{array}{c}\text { Pipe Re No. } \\ \left(/ / 10^{6}\right)\end{array} & \begin{array}{c}\text { C } \\ \text { CY }\end{array} \\ 102491-1 & 3.9912 & 287.76 & 47.09 & 35.236 & 1.1883 & 1.5902 & 0.6094 & 0.6104 \\ 102491-2 & 3.9950 & 287.31 & 47.22 & 35.130 & 1.1874 & 1.5907 & 0.6091 & 0.6101 \\ 102491-3 & 3.9362 & 287.06 & 46.57 & 20.026 & 0.8905 & 1.1944 & 0.6096 & 0.6101 \\ 102491-4 & 3.9359 & 287.33 & 46.52 & 20.124 & 0.8923 & 1.1961 & 0.6097 & 0.6102 \\ 102491-5 & 3.9348 & 286.57 & 46.64 & 57.319 & 1.5061 & 2.0226 & 0.6080 & 0.6095 \\ 102491-6 & 3.9333 & 286.74 & 46.59 & 56.961 & 1.4991 & 2.0124 & 0.6073 & 0.6089 \\ 102491-7 & 4.0203 & 287.45 & 47.50 & 7.453 & 0.5467 & 0.7318 & 0.6078 & 0.6080 \\ 102491-8 & 4.0211 & 287.63 & 47.47 & 7.556 & 0.5507 & 0.7369 & 0.6082 & 0.6084 \\ 102591-1 & 3.9039 & 287.24 & 46.15 & 19.677 & 0.8765 & 1.1756 & 0.6080 & 0.6086 \\ 102591-2 & 3.9042 & 287.22 & 46.16 & 19.598 & 0.8747 & 1.1733 & 0.6080 & 0.6085 \\ 102591-3 & 3.9213 & 287.27 & 46.35 & 8.915 & 0.5903 & 0.7916 & 0.6074 & 0.6076 \\ 102591-4 & 3.9224 & 287.53 & 46.32 & 8.987 & 0.5928 & 0.7943 & 0.6077 & 0.6079 \\ 102591-5 & 3.9318 & 287.31 & 46.47 & 36.972 & 1.2117 & 1.6244 & 0.6107 & 0.6117 \\ 102591-6 & 3.9245 & 287.80 & 46.30 & 36.855 & 1.2063 & 1.6154 & 0.6100 & 0.6111 \\ 102591-7 & 3.8669 & 287.71 & 45.63 & 59.624 & 1.5214 & 2.0393 & 0.6087 & 0.6103 \\ 102591-8 & 3.8642 & 287.43 & 45.65 & 59.118 & 1.5137 & 2.0304 & 0.6081 & 0.6097\end{array}$


Table 64. Measured and calculated quantities for 0.67 beta ratio plate, elbow at 170,113 at $120, f 1$ ange taps at position $B$.

Pipe Diameter $=5.250 \mathrm{~cm}(2.067 \mathrm{in}), 4.1 \mu \mathrm{m}$ Orifice Diameter $=3.4933 \mathrm{~cm}(1.3753 \mathrm{in})$

\begin{tabular}{|c|c|c|c|c|c|c|c|c|}
\hline Run ID & $\begin{array}{c}\text { Pressure } \\
\text { (MPa) }\end{array}$ & $\begin{array}{c}\text { Temperature } \\
\text { (K) }\end{array}$ & $\begin{array}{l}\text { Density } \\
\left(\mathrm{kg} / \mathrm{m}^{3}\right)\end{array}$ & $\begin{array}{c}\text { Dif Press } \\
(\mathrm{kPa})\end{array}$ & $\begin{array}{c}\text { Flow Rate } \\
\text { (kg/s) }\end{array}$ & $\begin{array}{c}\text { Pipe Re No. } \\
\left(/ 10^{6}\right)\end{array}$ & $C$ & $\mathrm{CY}_{2}$ \\
\hline $\begin{array}{l}102491-1 \\
102491-2 \\
102491-3 \\
102491-4 \\
102491-5 \\
102491-6 \\
102491-7 \\
102491-8 \\
102591-1 \\
102591-2 \\
102591-3 \\
102591-4 \\
102591-5 \\
102591-6 \\
102591-7 \\
102591-8\end{array}$ & $\begin{array}{l}3.9912 \\
3.9950 \\
3.9362 \\
3.9359 \\
3.9348 \\
3.9333 \\
4.0203 \\
4.0211 \\
3.9039 \\
3.9042 \\
3.9213 \\
3.9224 \\
3.9318 \\
3.9245 \\
3.8669 \\
3.8642\end{array}$ & $\begin{array}{l}287.76 \\
287.31 \\
287.06 \\
287.33 \\
286.57 \\
286.74 \\
287.45 \\
287.63 \\
287.24 \\
287.22 \\
287.27 \\
287.53 \\
287.31 \\
287.80 \\
287.71 \\
287.43\end{array}$ & $\begin{array}{l}47.09 \\
47.22 \\
46.57 \\
46.52 \\
46.64 \\
46.59 \\
47.50 \\
47.47 \\
46.15 \\
46.16 \\
46.35 \\
46.32 \\
46.47 \\
46.30 \\
45.63 \\
45.65\end{array}$ & $\begin{array}{r}35.215 \\
35.106 \\
20.013 \\
20.100 \\
57.264 \\
56.922 \\
7.432 \\
7.533 \\
19.682 \\
19.601 \\
8.901 \\
8.976 \\
36.989 \\
36.864 \\
59.600 \\
59.099\end{array}$ & $\begin{array}{l}1.1883 \\
1.1874 \\
0.8905 \\
0.8923 \\
1.5061 \\
1.4991 \\
0.5467 \\
0.5507 \\
0.8765 \\
0.8747 \\
0.5903 \\
0.5928 \\
1.2117 \\
1.2063 \\
1.5214 \\
1.5137\end{array}$ & $\begin{array}{l}1.5902 \\
1.5907 \\
1.1944 \\
1.1961 \\
2.0226 \\
2.0124 \\
0.7318 \\
0.7369 \\
1.1756 \\
1.1733 \\
0.7916 \\
0.7943 \\
1.6244 \\
1.6154 \\
2.0393 \\
2.0304\end{array}$ & $\begin{array}{l}0.6096 \\
0.6093 \\
0.6098 \\
0.6100 \\
0.6082 \\
0.6075 \\
0.6086 \\
0.6091 \\
0.6079 \\
0.6080 \\
0.6079 \\
0.6080 \\
0.6105 \\
0.6100 \\
0.6088 \\
0.6082\end{array}$ & $\begin{array}{l}0.6106 \\
0.6103 \\
0.6103 \\
0.6106 \\
0.6098 \\
0.6091 \\
0.6088 \\
0.6093 \\
0.6085 \\
0.6085 \\
0.6081 \\
0.6083 \\
0.6115 \\
0.6110 \\
0.6104 \\
0.6098\end{array}$ \\
\hline
\end{tabular}

Table 65. Measured and calculated quantities for 0.67 beta ratio plate, elbow at 17D, IT3 at 120, flange taps at position C. Pipe Diameter $=5.250 \mathrm{~cm}(2.067 \mathrm{in}), 4.1 \mu \mathrm{m}$ Orifice Diameter $=3.4933 \mathrm{~cm}(1.3753 \mathrm{in})$

\begin{tabular}{|c|c|c|c|c|c|c|c|c|}
\hline Run 10 & $\begin{array}{l}\text { Pressure } \\
\text { (MPa) }\end{array}$ & $\begin{array}{c}\text { Temperature } \\
\text { (K) }\end{array}$ & $\begin{array}{l}\text { Density } \\
\left(\mathrm{kg} / \mathrm{m}^{3}\right)\end{array}$ & $\begin{array}{c}\text { Dif Press } \\
\text { (kPa) }\end{array}$ & $\begin{array}{c}\text { F low Rate } \\
\text { (kg/s) }\end{array}$ & $\begin{array}{c}\text { Pipe Re No. } \\
\left(/ 10^{6}\right)\end{array}$ & $C$ & $\mathrm{CY}_{2}$ \\
\hline $\begin{array}{l}102491-1 \\
102491-2 \\
102491-3 \\
102491-4 \\
102491-5 \\
102491-6 \\
102491-7 \\
102491-8 \\
102591-1 \\
102591-2 \\
102591-3 \\
102591-4 \\
102591-5 \\
102591-6 \\
102591-7 \\
102591-8\end{array}$ & $\begin{array}{l}3.9912 \\
3.9950 \\
3.9362 \\
3.9359 \\
3.9348 \\
3.9333 \\
4.0203 \\
4.0211 \\
3.9039 \\
3.9042 \\
3.9213 \\
3.9224 \\
3.9318 \\
3.9245 \\
3.8669 \\
3.8642\end{array}$ & $\begin{array}{l}287.76 \\
287.31 \\
287.06 \\
287.33 \\
286.57 \\
286.74 \\
287.45 \\
287.63 \\
287.24 \\
287.22 \\
287.27 \\
287.53 \\
287.31 \\
287.80 \\
287.71 \\
287.43\end{array}$ & $\begin{array}{l}47.09 \\
47.22 \\
46.57 \\
46.52 \\
46.64 \\
46.59 \\
47.50 \\
47.47 \\
46.15 \\
46.16 \\
46.35 \\
46.32 \\
46.47 \\
46.30 \\
45.63 \\
45.65\end{array}$ & $\begin{array}{r}35.337 \\
35.218 \\
20.085 \\
20.172 \\
57.411 \\
57.048 \\
7.473 \\
7.578 \\
19.720 \\
19.647 \\
8.926 \\
9.000 \\
37.053 \\
36.941 \\
59.742 \\
59.213\end{array}$ & $\begin{array}{l}1.1883 \\
1.1874 \\
0.8905 \\
0.8923 \\
1.5061 \\
1.4991 \\
0.5467 \\
0.5507 \\
0.8765 \\
0.8747 \\
0.5903 \\
0.5928 \\
1.2117 \\
1.2063 \\
1.5214 \\
1.5137\end{array}$ & $\begin{array}{l}1.5902 \\
1.5907 \\
1.1944 \\
1.1961 \\
2.0226 \\
2.0124 \\
0.7318 \\
0.7369 \\
1.1756 \\
1.1733 \\
0.7916 \\
0.7943 \\
1.6244 \\
1.6154 \\
2.0393 \\
2.0304\end{array}$ & $\begin{array}{l}0.6086 \\
0.6083 \\
0.6087 \\
0.6090 \\
0.6075 \\
0.6069 \\
0.6069 \\
0.6073 \\
0.6074 \\
0.6072 \\
0.6070 \\
0.6072 \\
0.6100 \\
0.6093 \\
0.6081 \\
0.6076\end{array}$ & $\begin{array}{l}0.6095 \\
0.6093 \\
0.6093 \\
0.6095 \\
0.6090 \\
0.6084 \\
0.6071 \\
0.6075 \\
0.6079 \\
0.6078 \\
0.6072 \\
0.6075 \\
0.6110 \\
0.6103 \\
0.6097 \\
0.6092\end{array}$ \\
\hline
\end{tabular}

Table 66. Measured and calculated quantities for 0.67 beta ratio plate, elbow at $170, I T 3$ at $120, f l a n g e$ taps at position $D$.

Pipe Dianeter $=5.250 \mathrm{~cm}(2.067 \mathrm{in}), 4.1 \mu \mathrm{m}$ Orifice Diameter $=3.4933 \mathrm{~cm}(1.3753 \mathrm{in})$

$\begin{array}{lcccccccc}\text { Run 10 } & \begin{array}{c}\text { Pressure } \\ \text { (MPa) }\end{array} & \begin{array}{c}\text { Temperature } \\ (\mathrm{K})\end{array} & \begin{array}{c}\text { Density } \\ \left(\mathrm{kg} / \mathrm{m}^{3}\right)\end{array} & \begin{array}{c}\text { Dif Press } \\ (\mathrm{kPa})\end{array} & \begin{array}{c}\text { Flow Rate } \\ (\mathrm{kg} / \mathrm{s})\end{array} & \begin{array}{c}\text { Pipe Re No. } \\ \left(/ 10^{6}\right)\end{array} & \begin{array}{c}C \\ C Y_{2}\end{array} \\ 102491-1 & 3.9912 & 287.76 & 47.09 & 35.417 & 1.1883 & 1.5902 & 0.6079 & 0.6088 \\ 102491-2 & 3.9950 & 287.31 & 47.22 & 35.299 & 1.1874 & 1.5907 & 0.6076 & 0.6086 \\ 102491-3 & 3.9362 & 287.06 & 46.57 & 20.134 & 0.8905 & 1.1944 & 0.6080 & 0.6085 \\ 102491-4 & 3.9359 & 287.33 & 46.52 & 20.222 & 0.8923 & 1.1961 & 0.6082 & 0.6088 \\ 102491-5 & 3.9348 & 286.57 & 46.64 & 57.539 & 1.5061 & 2.0226 & 0.6068 & 0.6083 \\ 102491-6 & 3.9333 & 286.74 & 46.59 & 57.176 & 1.4991 & 2.0124 & 0.6062 & 0.6077 \\ 102491-7 & 4.0203 & 287.45 & 47.50 & 7.487 & 0.5467 & 0.7318 & 0.6064 & 0.6066 \\ 102491-8 & 4.0211 & 287.63 & 47.47 & 7.593 & 0.5507 & 0.7369 & 0.6067 & 0.6069 \\ 102591-1 & 3.9039 & 287.24 & 46.15 & 19.768 & 0.8765 & 1.1756 & 0.6066 & 0.6072 \\ 102591-2 & 3.9042 & 287.22 & 46.16 & 19.689 & 0.8747 & 1.1733 & 0.6066 & 0.6071 \\ 102591-3 & 3.9213 & 287.27 & 46.35 & 8.951 & 0.5903 & 0.7916 & 0.6062 & 0.6064 \\ 102591-4 & 3.9224 & 287.53 & 46.32 & 9.026 & 0.5928 & 0.7943 & 0.6063 & 0.6066 \\ 102591-5 & 3.9318 & 287.31 & 46.47 & 37.136 & 1.2117 & 1.6244 & 0.6093 & 0.6103 \\ 102591-6 & 3.9245 & 287.80 & 46.30 & 37.024 & 1.2063 & 1.6154 & 0.6086 & 0.6097 \\ 102591-7 & 3.8669 & 287.71 & 45.63 & 59.843 & 1.5214 & 2.0393 & 0.6075 & 0.6092 \\ 102591-8 & 3.8642 & 287.43 & 45.65 & 59.338 & 1.5137 & 2.0304 & 0.6069 & 0.6086\end{array}$







\section{Periodical}

Journal of Research of the National Institute of Standards and Technology - Reports NIST research and development in those disciplines of the physical and engineering sciences in which the Institute is active. These include physics, chemistry, engineering, mathematics, and computer sciences. Papers cover a broad range of subjects, with major emphasis on measurement methodology and the basic technology underlying standardization. Also included from time to time are survey articles on topics closely related to the Institute's technical and scientific programs. Issued six times a year.

\section{Nonperiodicals}

Monographs-Major contributions to the technical literature on various subjects related to the Institute's scientific and technical activities.

Handbooks-Recommended codes of engineering and industrial practice (including safety codes) developed in cooperation with interested industries, professional organizations, and regulatory bodies.

Special Publications-Include proceedings of conferences sponsored by NIST, NIST annual reports, and other special publications appropriate to this grouping such as wall charts, pocket cards, and bibliographies.

Applied Mathematics Series-Mathematical tables, manuals, and studies of special interest to physicists, engineers, chemists, biologists, mathematicians, computer programmers, and others engaged in scientific and technical work.

National Standard Reference Data Series-Provides quantitative data on the physical and chemical properties of materials, compiled from the world's literature and critically evaluated. Developed under a worldwide program coordinated by NIST under the authority of the National Standard Data Act (Public Law 90r396). NOTE: The Journal of Physical and Chemical Reference Data (JPCRD) is published quarterly for NIST by the American Chemical Society (ACS) and the American Institute of Physics (AIP). Subscriptions, reprints, and supplements are available from ACS, 1155 Sixteenth St., NW, Washington, DC 20056.

Building Science Series-Disseminates technical information developed at the Institute on building materials, components, systems, and whole structures. The series presents research results, test methods, and performance criteria related to the structural and environmental functions and the durability and safety characteristics of building elements and systems.

Technical Notes-Studies or reports which are complete in themselves but restrictive in their treatment of a subject. Analogous to monographs but not so comprehensive in scope or definitive in treatment of the subject area. Often serve as a vehicle for final reports of work performed at NIST under the sponsorship of other government agencies.

Voluntary Product Standards-Developed under procedures published by the Department of Commerce in Part 10, Title 15, of the Code of Federal Regulations. The standards establish nationally recognized requirements for products, and provide all concerned interests with a basis for common understanding of the characteristics of the products. NIST administers this program as a supplement to the activities of the private sector standardizing organizations.

Consumer Information Series-Practical information, based on NIST research and experience, covering areas of interest to the consumer. Easily understandable language and illustrations provide useful background knowledge for shopping in today's technological marketplace.

Order the above NIST publications from: Superintendent of Documents, Government Printing Office, Washington, DC 20402.

Order the following NIST publications-FIPS and NISTIRs-from the National Technical Information Service, Springfield, VA 22161.

Federal Information Processing Standards Publications (FIPS PUB)-Publications in this series collectively constitute the Federal Information Processing Standards Register. The Register serves as the official source of information in the Federal Government regarding standards issued by NIST pursuant to the Federal Property and Administrative Services Act of 1949 as amended, Public Law 89-306 (79 Stat. 1127), and as implemented by Executive Order 11717 (38 FR 12315, dated May 11, 1973) and Part 6 of Title 15 CFR (Code of Federal Regulations).

NIST Interagency Reports (NISTIR)-A special series of interim or final reports on work performed by NIST for outside sponsors (both government and non-government). In general, initial distribution is handled by the sponsor; public distribution is by the National Technical Information Service, Springfield, VA 22161. in paper copy or microfiche forin. 


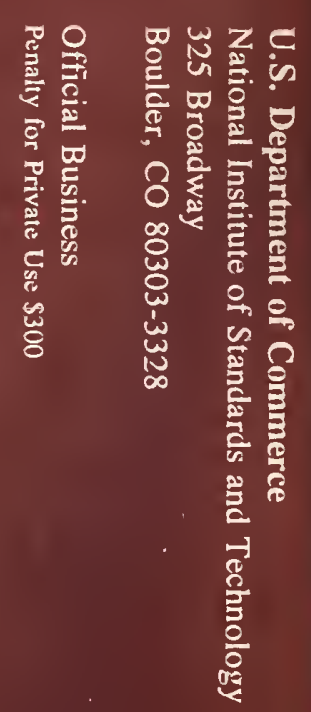

